UNIVERSIDADE DE SÃO PAULO

FACULDADE DE ECONOMIA, ADMINISTRAÇÃO E CONTABILIDADE DEPARTAMENTO DE ADMINISTRAÇÃO PROGRAMA DE PÓS-GRADUAÇÃO EM ADMINISTRAÇÃO

AS ATIVIDADES DE TRADE MARKETING APLICADAS AO SETOR FARMACÊUTICO

Tatiana Ferrara Barros

Orientador: Prof. Dr. Marcos Cortez Campomar

SÃO PAULO

2015 
Prof. Dr. Marco Antonio Zago

Reitor da Universidade de São Paulo

Prof. Dr. Adalberto Américo Fischmann

Diretor da Faculdade de Economia, Administração e Contabilidade

Prof. Dr. Roberto Sbragia

Chefe do Departamento de Administração

Prof. Dr. Moacir de Miranda Oliveira Júnior

Coordenador do Programa de Pós-Graduação em Administração 


\title{
AS ATIVIDADES DE TRADE MARKETING APLICADAS AO SETOR FARMACÊUTICO
}

Dissertação apresentada ao Departamento de Administração da Faculdade de Economia, Administração e Contabilidade da Universidade de São Paulo, como um dos requisitos para obtenção do título de Mestre em Administração.

Orientador: Prof. Dr. Marcos Cortez Campomar

\author{
Versão Corrigida \\ (Versão original disponível na Faculdade de Economia, Administração e Contabilidade) \\ SÃO PAULO




\section{FICHA CATALOGRÁFICA}

Elaborada pela Seção de Processamento Técnico do SBD/FEA/USP

\section{Barros, Tatiana Ferrara}

As atividades de trade marketing aplicadas ao setor farmacêutico / Tatiana Ferrara Barros. - São Paulo, 2015.

$177 \mathrm{p}$.

Dissertação (Mestrado) - Universidade de São Paulo, 2015.

Orientador: Marcos Cortez Campomar.

1. Marketing 2. Administração de vendas 3. Marketing farmacêutico 4. Canais de distribuição I. Universidade de São Paulo. Faculdade de Economia, Administração e Contabilidade. II. Título.

CDD -658.8 
Dedico esta dissertação aos meus Pais, Étena e José Roberto, e à minha irmã, Karina, pelo apoio incondicional e constante incentivo. 

A conquista de sonhos não é possível sem pessoas que acreditem em nosso potencial, nos estimulando principalmente nos momentos em que nem nós acreditamos em nós mesmos. Cada familiar, amigos e professores que passam por nós durante esta jornada tem um impacto, nos ensinando sempre algo a mais.

Gostaria de agradecer à minha família por todo o apoio e auxílio, não somente neste momento, mas durante toda a minha vida. Em cada projeto que eu decidi mergulhar, vocês estavam lá me dizendo que eu era capaz. Agradeço aos meus pais por tudo que me ensinaram, por toda a oportunidade que me deram ao longo da minha vida e por me darem uma irmã. À minha irmã agradeço pela amizade e pelas trocas de conhecimento. Agradeço ainda aos meus primos por toda a ajuda que me deram.

Ao Prof. Dr. Marcos Cortez Campomar, meu orientador, agradeço primeiramente por ter me escolhido como orientanda e me confiado esta preciosa oportunidade. Agradeço ainda por toda a contribuição e orientação para minha formação pessoal e profissional. Seus ensinamentos me fizeram de mim uma profissional e uma pessoa melhor.

Gostaria de agradecer também aos professores da área de marketing. Em especial: Profa. Dra. Ana Akemi Ikeda, Prof. Dr. Andres Veloso, Prof. Dr. Guilherme de Farias Shiraishi, Prof. Dr. Edson Crescitelli e Prof. Dr. Geraldo Luciano Toledo. Agradeço pelas conversas, esclarecimentos, orientações, conselhos e ajuda constante durante este período.

À Universidade de São Paulo e à sociedade brasileira que possibilitaram esta etapa da minha formação. Agradeço por possibilitar meus estudos.

À Editora Contento, seu diretor Gustavo Guimarães e sua equipe pela participação fundamental para o desenvolvimento de minha dissertação. Pelo apoio e pela colaboração que me proporcionaram.

À empresa Biolab e sua gerente de Trade Marketing, Ana Cruzato; à EMS e os gestores Marcel Bittencourt, Diego Tognonato D’Albergaria Pamplona e José Octávio Costa Auler Neto; à Sandoz e a gerente de Trade Marketing Flavia Osaki e ao laboratório Zambon e ao gerente comercial Alan Tosetto por todo o apoio disponibilidade despendido para a coleta de informações da pesquisa de campo da dissertação.

Aos amigos que ganhei na FEA, agradeço por todos os Happy Hours, momentos de descontração, brincadeiras e risadas. As amizades que desenvolvi, com certeza, serão para toda a vida. Agradeço de coração a todos aqueles que contribuíram para a realização da minha dissertação. Obrigada! 

"A mente que se abre para uma ideia jamais voltará ao seu tamanho original" Albert Einstein 



\section{RESUMO}

Devido ao aumento da concorrência no ponto de venda, mais atenção tem sido dedicada aos canais de distribuição. Além disso, é preciso conquistar a preferência do consumidor no momento da compra. Por esse motivo, diversas empresas têm inserido em suas estruturas organizacionais uma área chamada Trade Marketing.

O mesmo fenômeno ocorre no setor farmacêutico: os medicamentos genéricos, similares e referencia competem pela preferência dos consumidores. Este fato contribui para a criação de departamentos de Trade Marketing nas indústrias farmacêuticas. O Trade Marketing pode proporcionar a integração entre produtores, atacadistas e varejistas, trabalhando no relacionamento com os canais de distribuição.

Entretanto, é ainda um tema recente e pouco estudado na academia e, por isso, existem lacunas a serem exploradas. Dentre os assuntos mais abordados na literatura encontram-se estudos de Trade Marketing no setor alimentício. Assim, restam lacunas a respeito das atividades de Trade Marketing desenvolvidas no setor farmacêutico. Portanto, o objetivo do presente estudo é verificar como ocorre o processo de desenvolvimento das atividades de Trade Marketing na indústria farmacêutica.

Para atingir o objetivo proposto, realizou-se uma pesquisa de caráter exploratório e qualitativo. Utilizou-se como método o estudo de casos múltiplos. A pesquisa de campo foi realizada em quatro indústrias farmacêuticas e a principal fonte de informação foi entrevistas com os gestores da área de Trade Marketing.

Por meio da pesquisa, foi possível definir as atividades de Trade Marketing desenvolvidas pelas empresas estudadas. Além disso, é perceptível que os departamentos de Trade Marketing mais desenvolvidos são aqueles que trabalham com linhas de produtos com maior concorrência, como os medicamentos genéricos.

Palavras chave: Marketing; Administração de Vendas; Marketing Farmacêutico; Canais de Distribuição. 



\begin{abstract}
Due to the raising competition in point of purchase, more attention has been dedicated to the distribution channels. Moreover, it is necessary to conquer the consumers' preference while shopping. For this reason, several companies have created Trade Marketing areas in their organizational structure.

The same happens in the pharmaceutical sector: drugs companies compete for bigger market share. This fact contributes to the creation of Trade Marketing departments on the pharmaceutical industries. Trade Marketing can help integrate producers, wholesalers and retailers, build relationships in the distributions channels.

However, there is a lot of research yet to be done. The academy has only stablished benchmarking studies concerning the food industry. So, there still gaps to be filled about the Trade Marketing activities in the pharmaceutical sector. Therefore, this study's aim is to verify how the development process of Trade Marketing activities has been happening in the pharmaceutical industry.

In order to achieve such objectives, an exploratory and qualitative research has been conducted, applying multiple case study method. The empirical research, which had, as main source of information, interviews with Trade Marketing managers, took place in four pharmaceutical industries.

This research made possible to define the Trade Marketing activities developed by the studied companies. Furthermore, was recognisable that the more competitive was the market, the more developed were the Trade Marketing departments, e.g. generic drug companies.
\end{abstract}

Keywords: Marketing; Sales Management; Pharmaceutical Marketing; Distribution Channels. 



\section{SUMÁRIO}

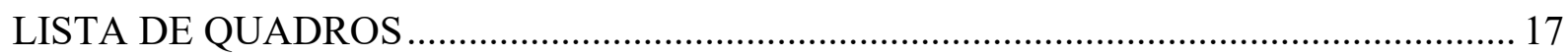

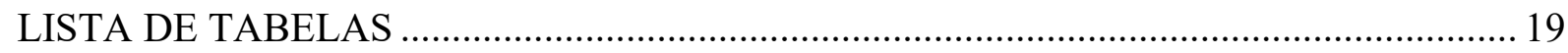

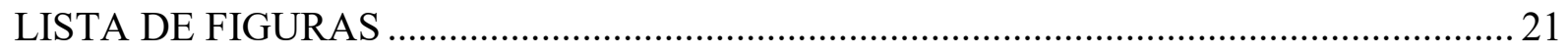

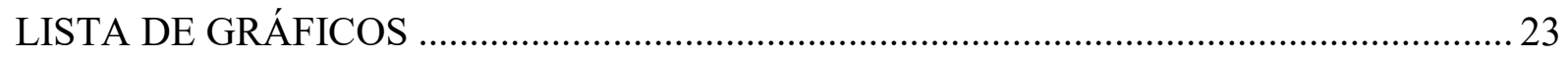

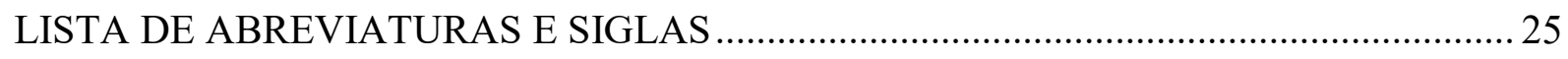

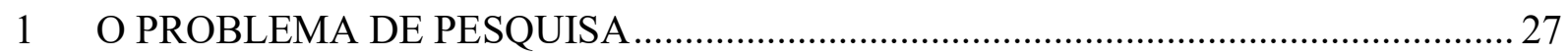

1.1 Introdução e contextualização do problema de pesquisa........................................ 27

1.2 Definição da situação problema ........................................................................ 29

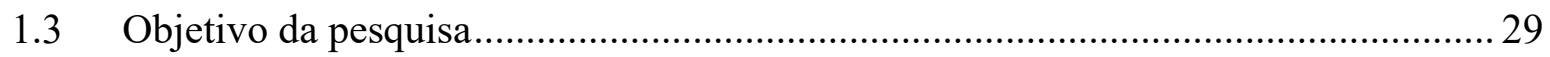

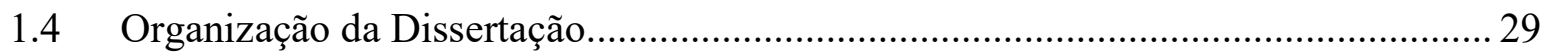

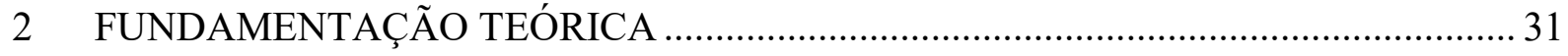

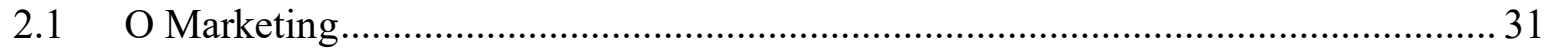

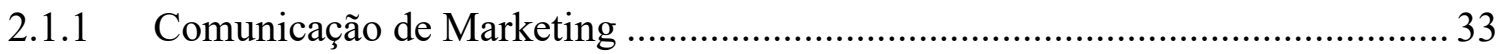

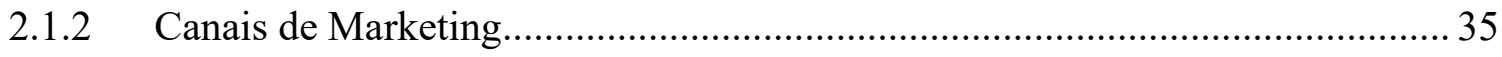

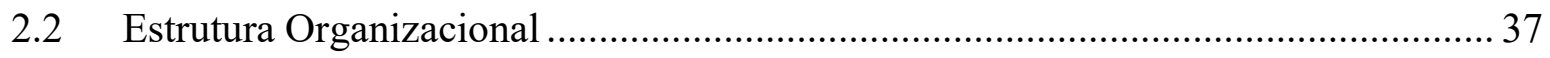

2.2.1 Estrutura Organizacional de Marketing .................................................... 40

2.2.2 O Trade Marketing na estrutura organizacional........................................... 43

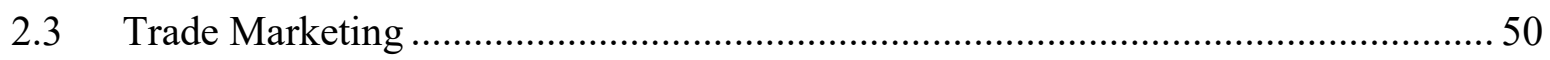

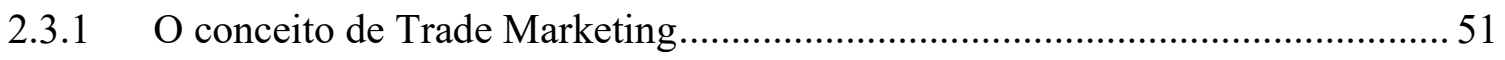

2.3.2 Funções do Trade Marketing....................................................................... 53

2.3.2.1 Segmentação dos Canais de Distribuição .................................................. 54

2.3.2.2 Sistema de Informação de Trade Marketing .............................................. 55

2.3.2.3 Comportamento do Shopper ................................................................. 57

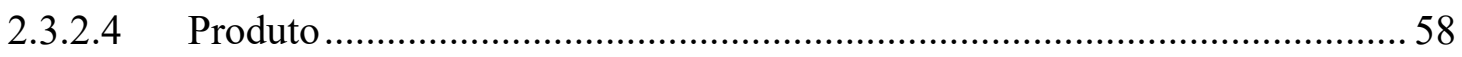

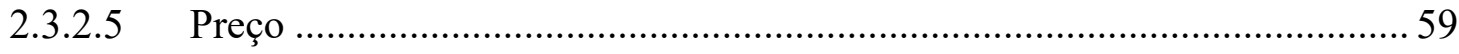

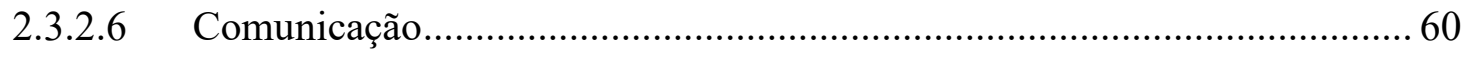

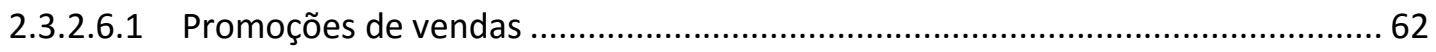

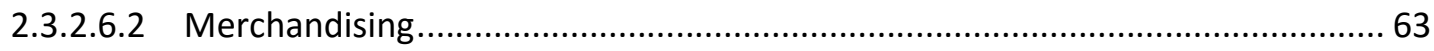




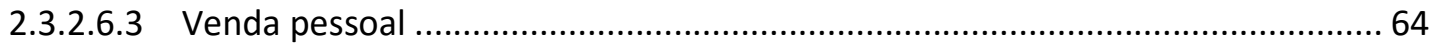

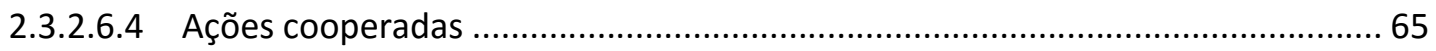

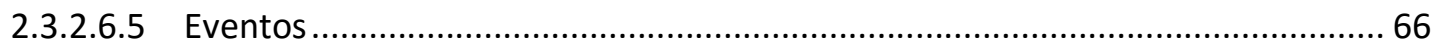

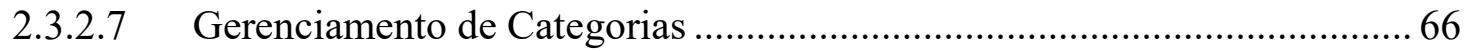

2.3.2.8 Relacionamento com os canais de distribuição ....................................... 67

2.3.2.9 Plano de Trade Marketing............................................................................ 68

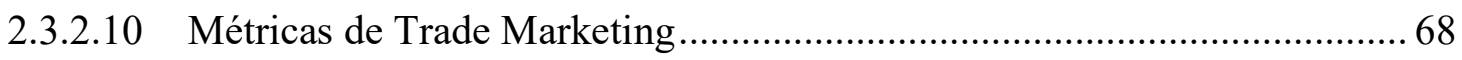

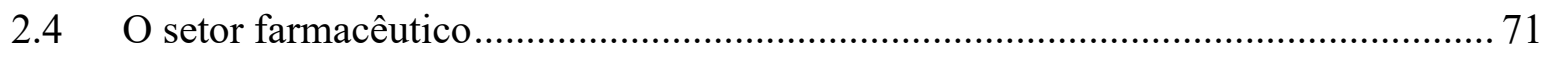

2.4.1 Contexto histórico dos medicamentos no Brasil ............................................... 76

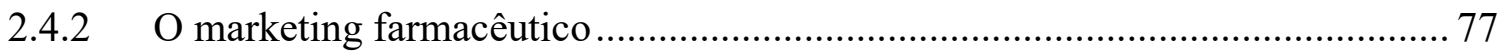

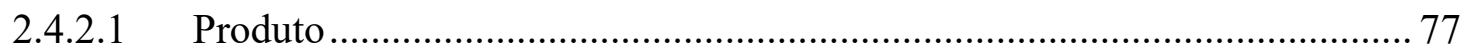

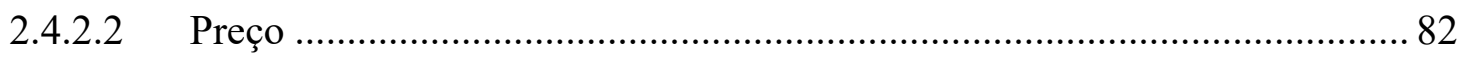

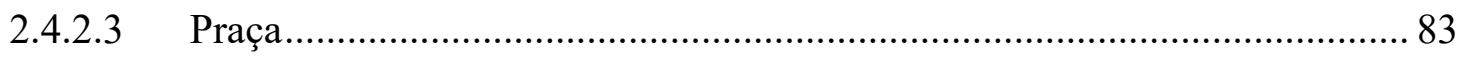

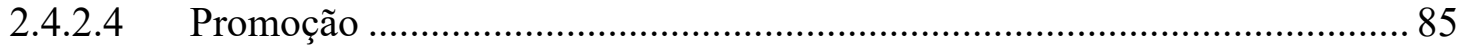

3 PROCEDIMENTOS METODOLÓGICOS DA PESQUISA DE CAMPO …................. 87

3.1 Abordagem e classificação da metodologia da pesquisa de campo .......................... 87

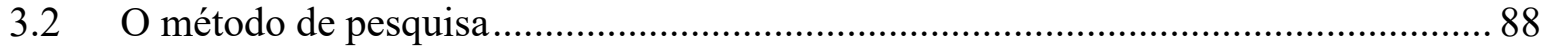

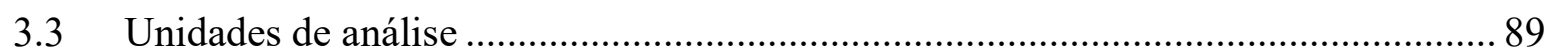

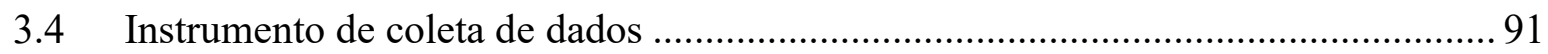

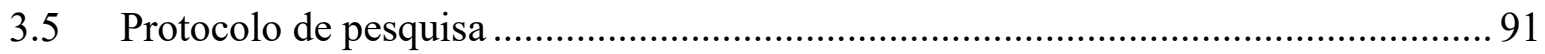

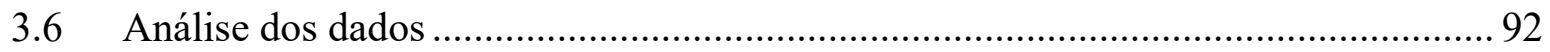

4 PESQUISA DE CAMPO: APRESENTAÇÃO E ANÁLISE DOS DADOS ................... 95

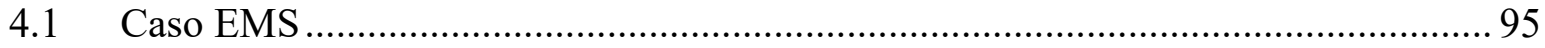

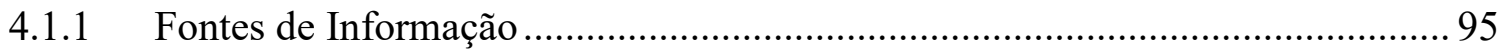

4.1.2 Informações gerais sobre a organização.......................................................... 96

4.1.3 Descrição e análise do caso EMS Marcas ........................................................ 97

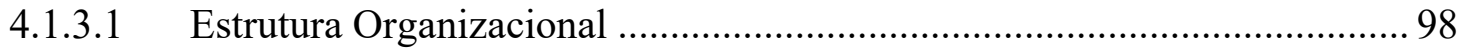

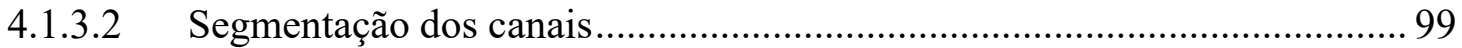

4.1.3.3 Sistema de Informação de Trade Marketing ............................................... 100

4.1.3.4 Comportamento do Shopper ................................................................. 100 


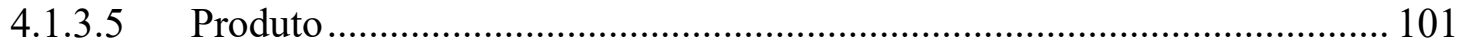

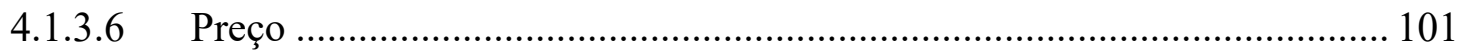

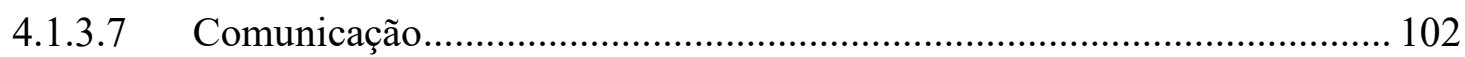

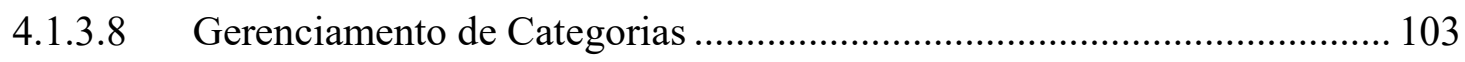

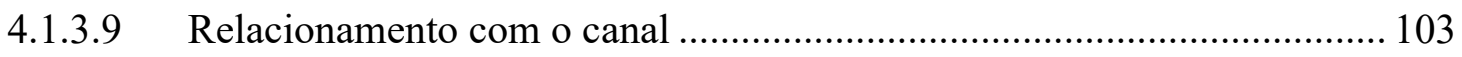

4.1.3.10 Plano de Trade Marketing................................................................... 104

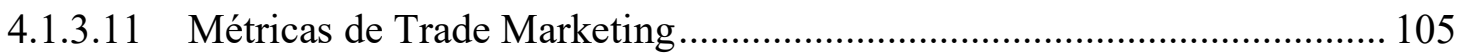

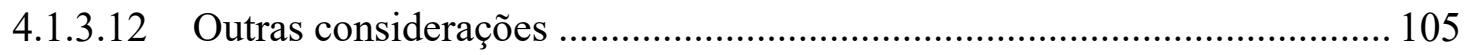

4.1.4 Descrição e análise do caso EMS Genéricos ................................................... 105

4.1.4.1 Estrutura Organizacional ....................................................................... 107

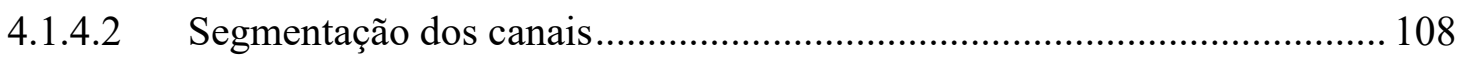

4.1.4.3 Sistema de Informação de Trade Marketing ............................................... 108

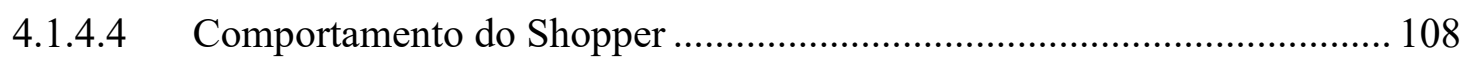

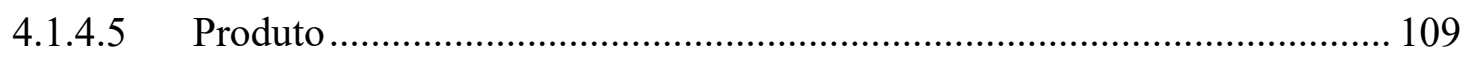

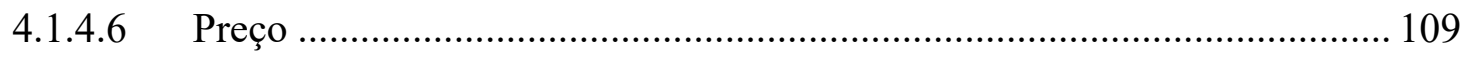

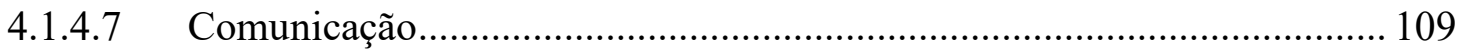

4.1.4.8 Gerenciamento de Categorias .............................................................. 110

4.1.4.9 Relacionamento com o cliente ............................................................... 110

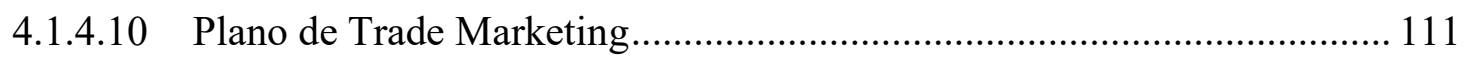

4.1.4.11 Métricas de Trade Marketing........................................................................ 111

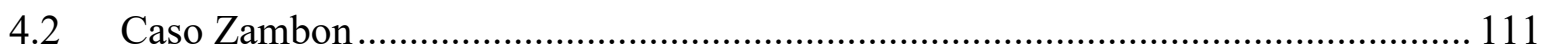

4.2.1 Fontes de informação ..................................................................................... 111

4.2.2 Informações Gerais sobre a organização.......................................................... 112

4.2.3 Descrição e análise do caso Zambon................................................................ 113

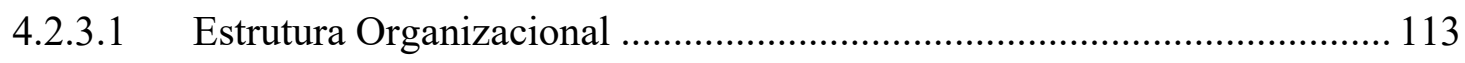

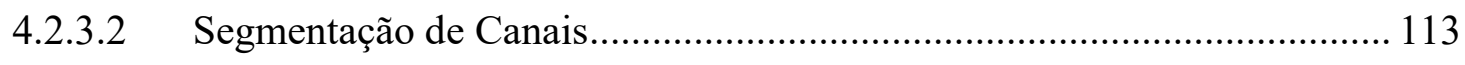

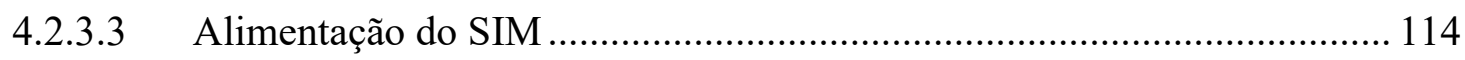

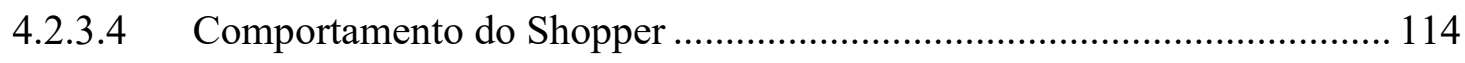

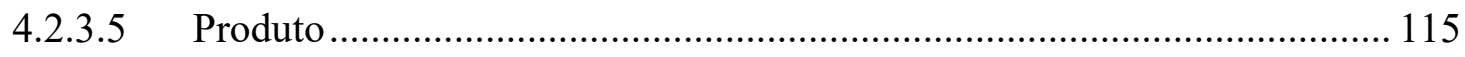

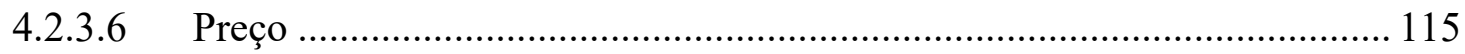

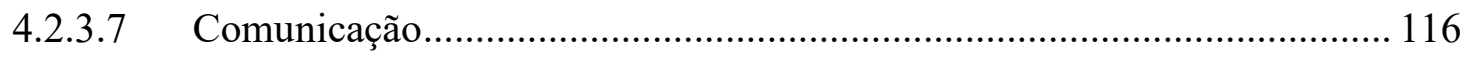

4.2.3.8 Gerenciamento por Categorias............................................................ 117 


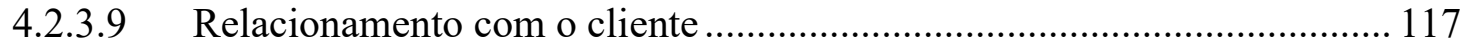

4.2.3.10 Plano de Trade Marketing .......................................................................... 118

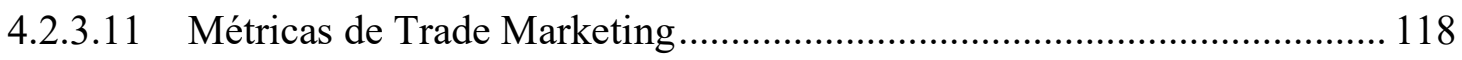

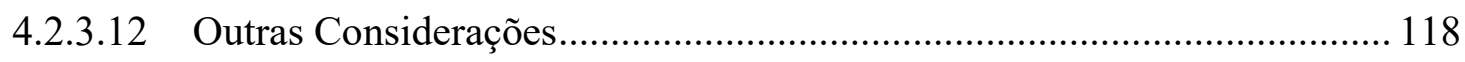

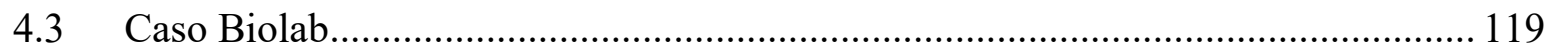

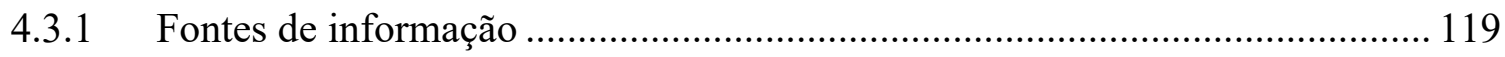

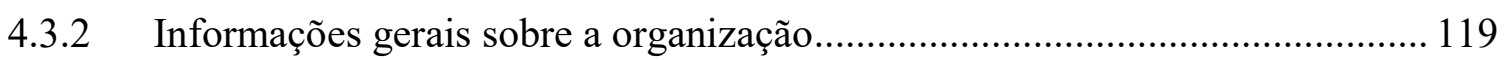

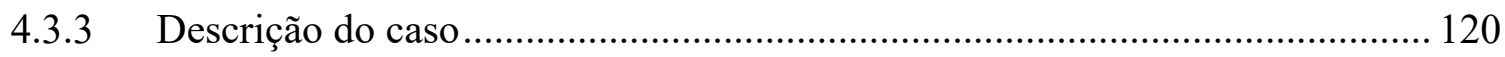

4.3.3.1 Estrutura Organizacional ….............................................................. 120

4.3.3.2 Segmentação dos canais de distribuição .................................................. 121

4.3.3.3 Sistema de Informação de Trade Marketing ............................................. 121

4.3.3.4 Comportamento do Shopper ................................................................. 122

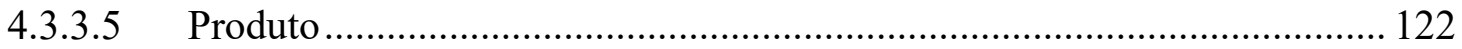

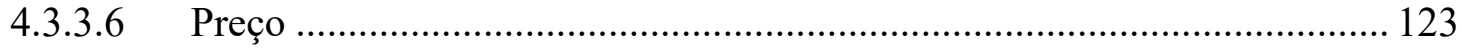

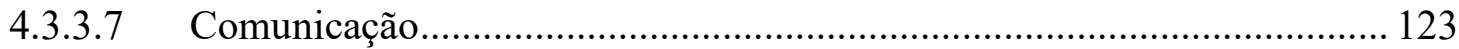

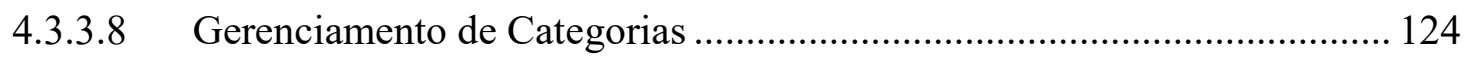

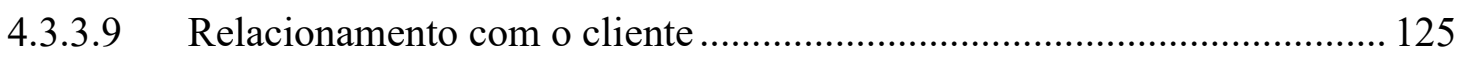

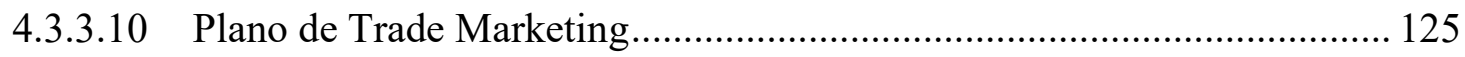

4.3.3.11 Métricas de Trade Marketing .................................................................. 126

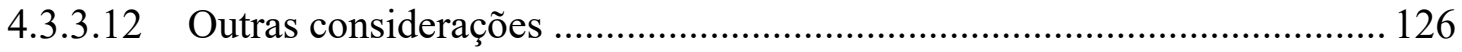

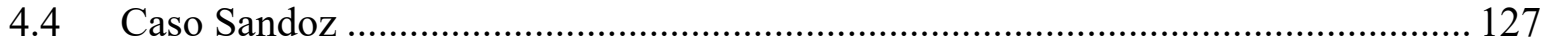

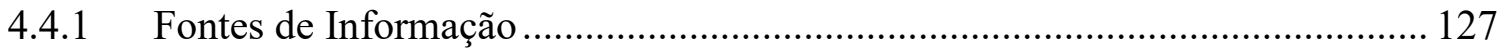

4.4.2 Informações gerais sobre a organização....................................................... 127

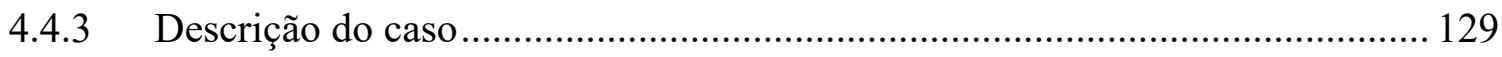

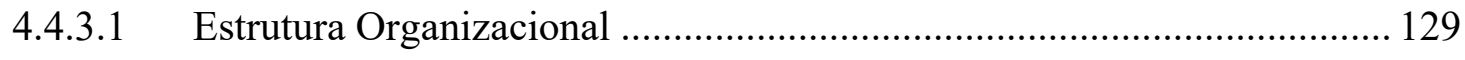

4.4.3.2 Segmentação dos canais de distribuição .................................................. 130

4.4.3.3 Sistema de Informação de Trade Marketing .............................................. 130

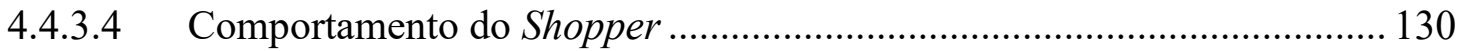

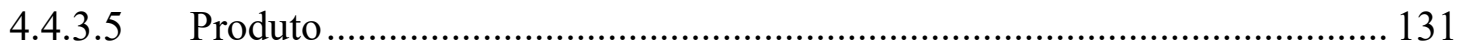

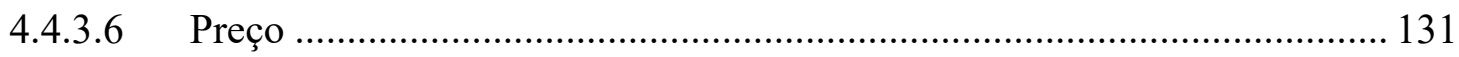

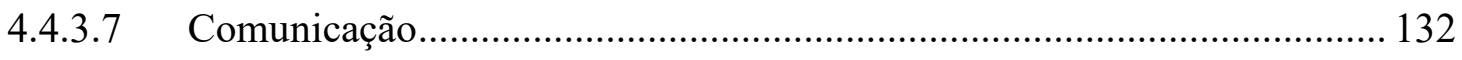

4.4.3.8 Gerenciamento de Categorias .......................................................... 133 


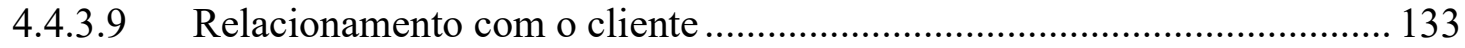

4.4.3.10 Plano de Trade Marketing............................................................................ 134

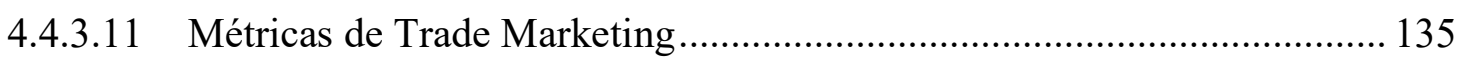

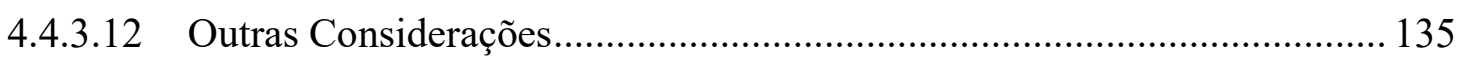

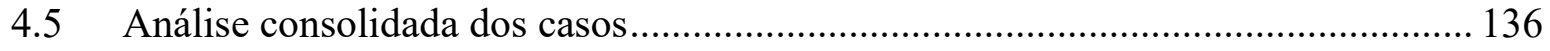

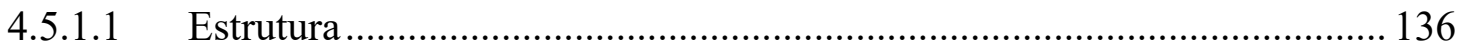

4.5.1.2 Segmentação dos canais de distribuição ................................................ 138

4.5.1.3 Sistema de Informação de Trade Marketing ............................................. 139

4.5.1.4 Comportamento do Shopper ............................................................... 141

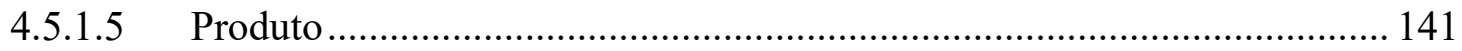

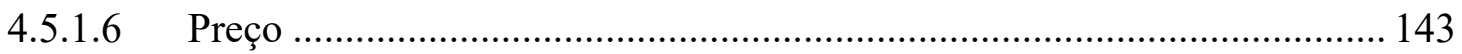

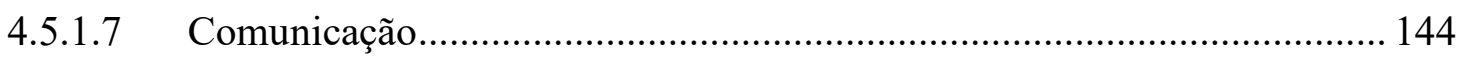

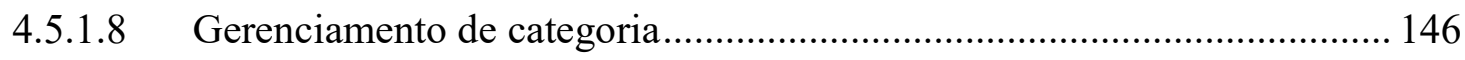

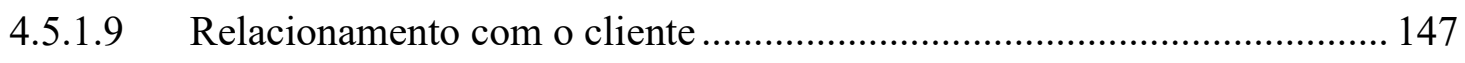

4.5.1.10 Plano de Trade Marketing ......................................................................... 148

4.5.1.11 Métricas de Trade Marketing .................................................................. 149

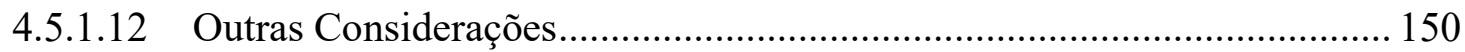

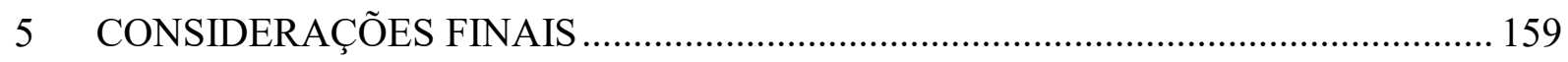

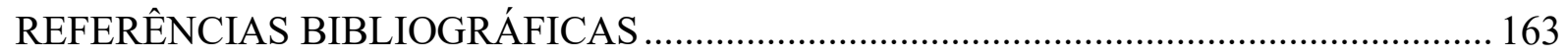

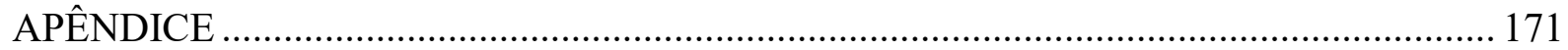

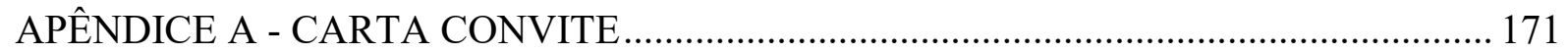

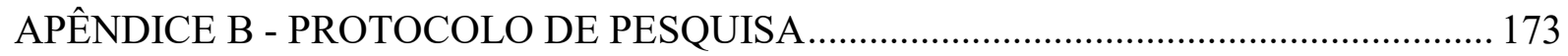

APÊNDICE C - ROTEIRO DE ENTREVISTAS ........................................................... 175 



\section{LISTA DE QUADROS}

Quadro 1 - As ferramentas das comunicações de marketing................................................. 33

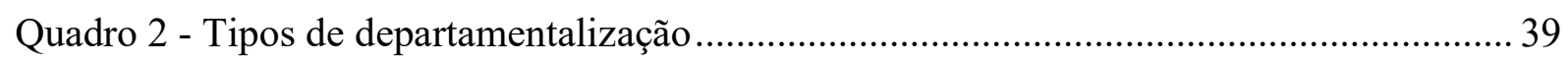

Quadro 3 - Resumo dos conceitos de Trade Marketing ........................................................... 53

Quadro 4 - Critérios utilizados na segmentação dos canais ................................................... 55

Quadro 5 - Ações relacionadas ao Sistema de Informação de Trade Marketing ..................... 56

Quadro 6 - Ações relacionadas ao Comportamento do Shopper ............................................ 58

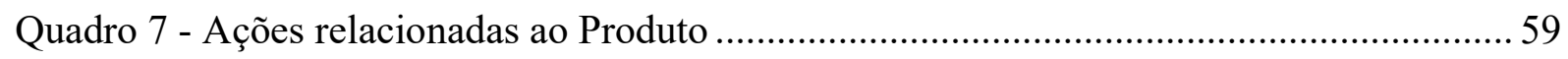

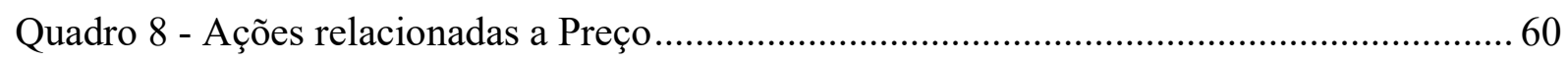

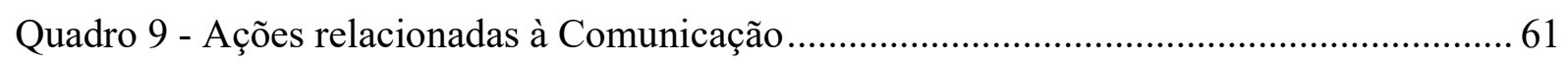

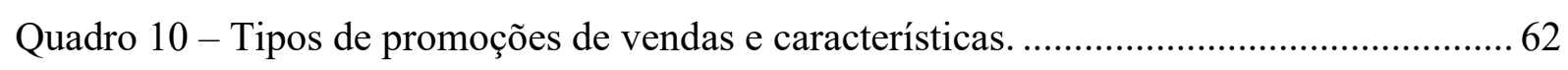

Quadro 11 - Ações relacionadas ao Gerenciamento de Categorias. ........................................ 67

Quadro 12 - Ações para desenvolvimento do Relacionamento com os Canais de Distribuição

Quadro 13 - Métricas utilizadas em Trade Marketing ....................................................... 70

Quadro 14 - Ranking dos maiores laboratórios farmacêuticos do Brasil em 2013................ 74

Quadro 15 - Ranking de produtos farmacêuticos mais vendidos no Brasil no ano de 2013 .... 75

Quadro 16 - Elemento de comunicação e restrições legais para medicamentos ....................... 85

Quadro 17 - Formas de classificação da pesquisa científica ................................................. 87

Quadro 18 - Linha de produtos EMS Marcas ........................................................................ 98

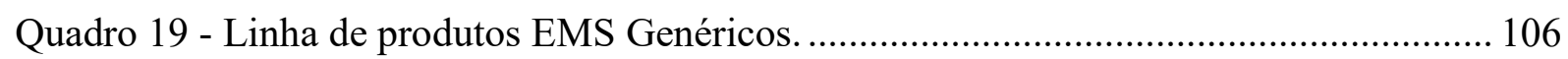

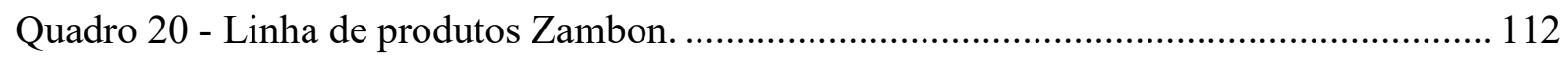

Quadro 21 - Linha de produtos Biolab e Avert..................................................................... 120

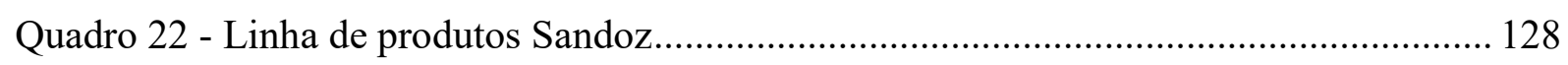

Quadro 23 - Descrição das atividades relativas à segmentação desenvolvidas pelo Trade

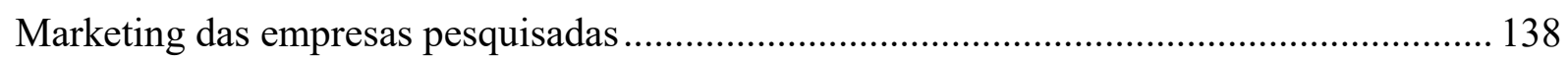

Quadro 24 - Descrição das atividades relativas a Sistema de Informação desenvolvidas pelo

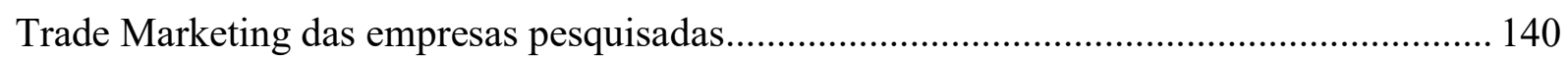

Quadro 25 - Descrição das atividades relativas a comportamento do shopper desenvolvidas pelo Trade Marketing das empresas pesquisadas ................................................................ 141

Quadro 26 - Descrição das atividades relativas a produto desenvolvidas pelo Trade Marketing das empresas pesquisadas.

Quadro 27 - Descrição das atividades relativas a preço desenvolvidas pelo Trade Marketing das empresas pesquisadas. 
Quadro 28 - Descrição das atividades relativas à comunicação desenvolvidas pelo Trade Marketing das empresas pesquisadas 145

Quadro 29 - Descrição das atividades relativas a gerenciamento de categorias desenvolvidas pelo Trade Marketing das empresas pesquisadas 147

Quadro 30 - Descrição das atividades relativas a sistema de informação desenvolvidas pelo Trade Marketing das empresas pesquisadas. 148 Quadro 31 - Descrição das atividades relativas ao Plano de Trade Marketing desenvolvidas pelo Trade Marketing das empresas pesquisadas 148 Quadro 32 - Descrição das métricas de Trade Marketing utilizadas pelas empresas pesquisadas.

Quadro 33 - Resumo das atividades que podem ser desenvolvidas pelo Trade Marketing ... 160 


\section{LISTA DE TABELAS}

Tabela 1 - Relação entre os critérios adotados para seleção das unidades de análise e empresas .90

Tabela 2 - Relação entre os principais temas de estruturas e casos estudados. 137

Tabela 3 - Comparação das atividades evidenciadas na pesquisa de campo com a literatura 151

Tabela 4 - Resumo dos principais achados do trabalho de campo. 155 


\section{LISTA DE FIGURAS}

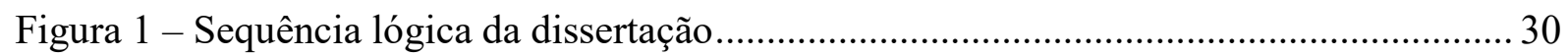

Figura 2 - Áreas básicas da Administração de Empresas. ...................................................... 31

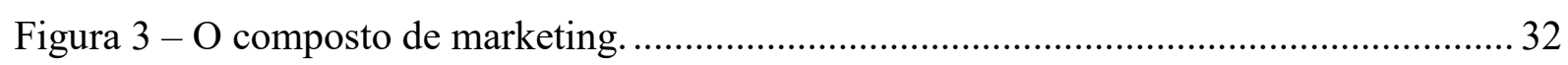

Figura 4 - Custos de contato para alcançar o mercado sem intermediários. ............................ 36

Figura 5 - Custos de contato para alcançar o mercado utilizando um intermediário............... 36

Figura 6 - Custos de contato para alcançar o mercado utilizando dois intermediários. ............ 36

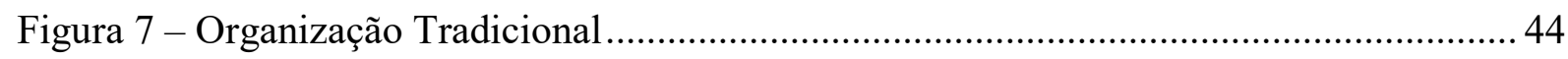

Figura 8 - Organização tradicional com inserção do departamento de Trade Marketing

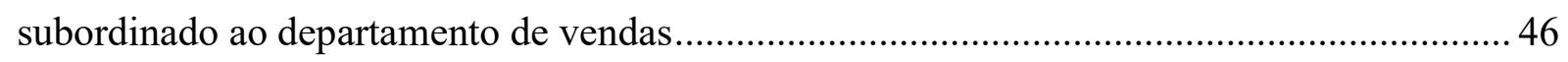

Figura 9 - Organização tradicional com inserção do departamento de Trade Marketing

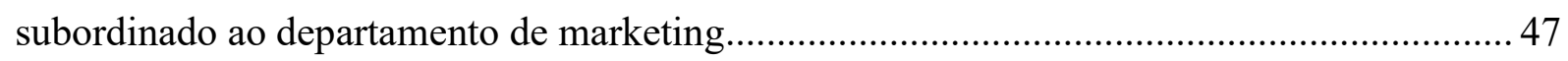

Figura 10 - Organização tradicional com departamento de Trade Marketing ......................... 48

Figura 11 - Evolução das fases de implantação do Trade Marketing....................................... 50

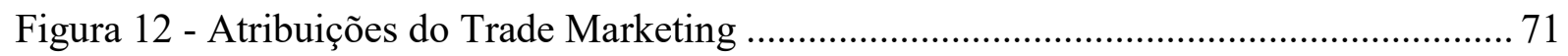

Figura 13 - Categorias produzidas e comercializadas no setor farmacêutico. ........................ 78

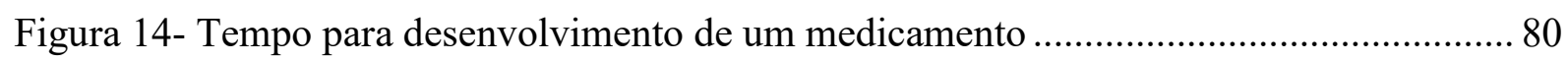

Figura 15 - Intercambialidade de medicamentos. ................................................................ 82

Figura 16 - Procedimentos para realização de estudo de caso ............................................... 93

Figura 17 - Evolução das fases de implantação do Trade Marketing ……............................ 138 


\section{LISTA DE GRÁFICOS}

Gráfico 1 - Total de vendas no mercado farmacêutico brasileiro ......................................... 72

Gráfico 2 - Total de unidades vendidas no mercado farmacêutico brasileiro ......................... 73

Gráfico 3 - Volume de vendas de medicamentos genéricos no período de 2003 a 2015, no

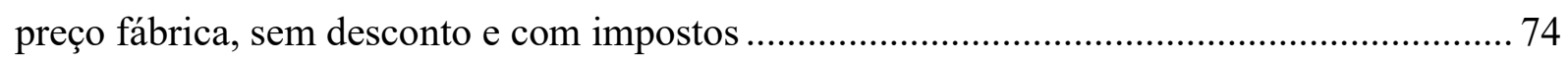




\section{LISTA DE ABREVIATURAS E SIGLAS}

ANVISA - Agencia Nacional de Vigilância Sanitária

CMED - Câmara de Regulação do Mercado de Medicamentos

DCB - Denominação Comum Brasileira

ECR - Efficient Consumer Response

GITE - Lista de Grupos e Indicações Terapêuticas Especificadas

MIP - Medicamento Isento de Prescrição.

OTC - Over the Counter

PDV - Ponto de venda

PF - Preço Fábrica

PMC - Preço Máximo ao Consumidor

$\mathrm{RX}$ - Receipe 


\section{O PROBLEMA DE PESQUISA}

\subsection{Introdução e contextualização do problema de pesquisa}

O Trade Marketing é uma área empresarial que, cada vez mais, ganha destaque nas organizações. No setor farmacêutico, devido às suas particularidades em relação ao ambiente legal, o departamento de Trade Marketing torna viável e fortifica a comunicação de produtos farmacêuticos. Além disso, proporciona a integração entre produtores, atacadistas e varejistas do setor. Entretanto, ainda é um tema recente e pouco estudado na academia, restando lacunas a serem preenchidas.

Com a evolução do ambiente de negócios e aumento da força da concorrência entre as empresas, há a necessidade de redefinir as estratégias da organização, e, portanto, redefinir também suas estruturas organizacionais. Por meio da estrutura organizacional, é possível que as empresas executem suas estratégias e assim, atinjam seus objetivos (SHIRAISHI, 2009). Mudanças ocorridas devido a dinâmica de poder no canal de distribuição podem gerar a necessidade de alteração da estrutura organizacional.

A força do varejo e a competitividade entre os fabricantes aumentaram. Consequentemente há mais disputa por espaço no varejo, resultando em grande concorrência no ponto de venda (ALVAREZ, 2008, p. 2; RANDALL, 1994, p. vii). A relação entre produtores e distribuidores é amplamente discutida na literatura (ACHROL; REVE; STERN, 1983; ANDERSON; NARUS, 1984; GEYSKENS; STEENKAMP; KUMAR, 1999), assim como os conflitos entre os membros dos canais de distribuição (DAVIES, 1990; DHAR; HOCH; KUMAR, 2001; ELIASHBERG; MICHIE, 1984; ROSENBERG; STERN, 1970; ROSENBLOOM, 1973).

A fim de conquistar a preferência do consumidor no ponto de venda, as empresas fabricantes de bens de consumo necessitam fortificar suas ações de promoção de vendas e merchandising, com o objetivo de promover as vendas e aumentar o giro dos produtos (ALVAREZ, 2008, p. 2; FERRACCIÙ, 2007, p. 9). Assim, o relacionamento com os canais de distribuição e ações no ponto de venda ganham mais importância na estrutura organizacional. São criados, então, os departamentos de Trade Marketing.

A discussão sobre Trade Marketing na literatura é relativamente recente quando comparada a outras áreas (ALVAREZ, 2008; CÔNSOLI; D'ANDREA, 2010; DUPUIS; 
TISSIER-DESBORDES, 1994, 1996; MOTTA, 2007; SERRALVO; JOÃO; CARDOSO, 2011). Alguns estudos acadêmicos que tratam de Trade Marketing atêm-se principalmente na discussão da origem e conceito (DUPUIS; TISSIER-DESBORDES, 1994, 1996), atuação do Trade Marketing na relação indústria com o varejo (SERRALVO; JOÃO; CARDOSO, 2011) e na organização do Trade Marketing na estrutura organizacional. Os setores estudados, são lojas de conveniência (ALMEIDA et al., 2012) e o varejo alimentício (ALVAREZ, 1999; MOTTA, 2007).

Segundo dados da Interfarma (2014), o mercado farmacêutico mundial movimentou cerca de 980 trilhões de dólares em 2013. O Brasil ocupa a sexta posição no mercado mundial, sendo responsável pelo faturamento de 58 bilhões de dólares no ano de 2013. Por lidar com produtos relacionados à saúde, a área farmacêutica é extremamente regulamentada pelos órgãos governamentais em diversos aspectos. Muitas legislações influenciam diretamente as ações de marketing e tornam esta atividade desafiadora no setor.

Durante muito tempo, a indústria farmacêutica focou seus esforços de promoção na visitação médica, acreditando que esta ação seria suficiente para manter suas vendas. Ao gerar a prescrição médica, as indústrias confiam que o consumidor irá efetuar a compra do medicamento prescrito. Entretanto, no ambiente da farmácia o consumidor pode decidir pela compra uma marca diferente da que foi receitada. Com o início da comercialização de medicamentos genéricos no Brasil possibilitou-se a substituição do medicamento de referência pelo medicamento genérico e, mais recentemente, a introdução do medicamento similar equivalente abre possibilidade para outras substituições. Além disso, o setor tem passado por inúmeras fusões e aquisições em toda a cadeia, englobando a indústria, atacadistas e varejistas, o que altera a relação de poder no canal.

Todas as mudanças ocorridas no setor tornam o varejo essencial para as indústrias e também as ações no ponto de vendas fundamentais para as marcas. Neste contexto, entender como a indústria farmacêutica aplica e faz uso das ferramentas de Trade Marketing, pode fornecer uma contribuição à literatura do tema, aprofundando a compreensão do conhecimento da área de Trade Marketing no setor farmacêutico. Inclusive porque a literatura sobre Trade Marketing está focada no setor alimentício (ALMEIDA et al., 2012; ALVAREZ, 1999; MOTTA, 2007) e porque não foram encontradas pesquisas sobre Trade Marketing no setor farmacêutico especificamente. 


\subsection{Definição da situação problema}

Portanto, propõe-se um aprofundamento do tema no intuito de responder ao seguinte questionamento: o que é e como funciona o Trade Marketing no setor farmacêutico?

\subsection{Objetivo da pesquisa}

Diante do problema de pesquisa apresentado, o seguinte objetivo é proposto: verificar como ocorre o desenvolvimento das atividades de Trade Marketing na indústria farmacêutica.

\subsection{Organização da dissertação}

O presente trabalho foi organizado contemplando capítulos destinados à introdução, revisão da literatura, abordagem metodológica, pesquisa de campo e considerações finais. Ao final foi inserido um glossário para consulta quando o leitor sentir necessidade.

No capítulo 1, introdução, foi abordado a importância do estudo do tema escolhido, as principais lacunas existentes na literatura, o problema de pesquisa e o objetivo da dissertação. O presente item também está contido neste capítulo, a fim de propiciar a visão geral da organização da dissertação.

Em seguida, no segundo capítulo, foi realizada a revisão da literatura. Este capítulo contempla um item sobre o marketing, com objetivo de localizar e relacionar o tema escolhido dentro da área. O próximo item, estrutura organizacional, discute as estruturas das empresas, em especial na área de marketing, a fim de demostrar como e por que surgem departamentos de Trade Marketing. No item sobre Trade Marketing, efetuou-se uma revisão dos trabalhos sobre o tema, abordando primeiramente os conceitos encontrados na literatura e, na sequência, as funções que são desempenhadas, relatadas na teoria. Por fim, um item sobre o setor farmacêutico tem como objetivo demonstrar as peculiaridades do setor, principalmente em relação à aplicação das atividades do marketing.

O capítulo 3 descreve a abordagem metodológica escolhida. Neste capítulo é explicado o método escolhido, assim como a justificativa para sua escolha. Além disso, foram detalhados os critérios para a escolha das unidades de análise, apresentado o instrumento de coleta de dados, o protocolo utilizado para desenvolvimento da pesquisa de campo e a forma como os dados foram analisados. 
A pesquisa de campo é apresentada no capítulo 4. São descritos os casos escolhidos e desenvolvida a análise de cada um deles. A seguir foi efetuada a análise consolidada dos casos, na qual foi realizada uma comparação entre os mesmos.

Por fim, o quinto capítulo contempla as considerações finais: nelas são apresentadas as contribuições do estudo, suas limitações e sugestões para trabalhos futuros. A Figura 1 demonstra um esquema da sequência lógica utilizada na dissertação.

Figura 1 - Sequência lógica da dissertação

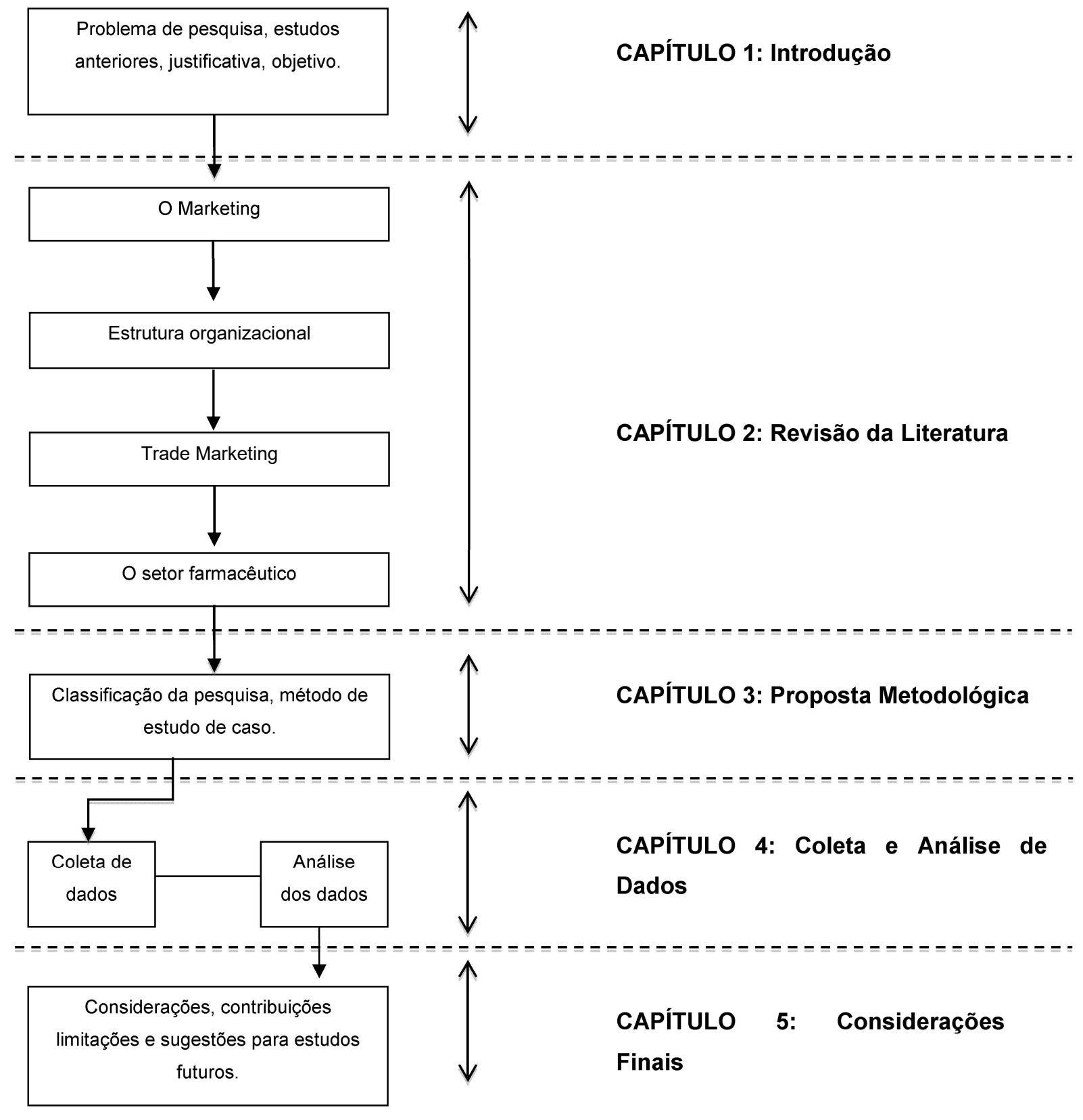

Fonte: elaborada pela autora. 


\section{FUNDAMENTAÇÃO TEÓRICA}

Para alcançar o objetivo proposto no presente trabalho, foi necessário, primeiramente, efetuar a revisão da literatura sobre alguns tópicos relacionados ao Trade Marketing. A fundamentação teórica foi desenvolvida abordando os seguintes itens: marketing, estrutura organizacional, trade marketing e o setor farmacêutico.

\subsection{O Marketing}

O presente item tem como objetivo localizar a área de Trade Marketing na administração de empresas e no marketing. São apresentadas as áreas da administração e serão apresentados os 4 P's. A praça e promoção detalhados, pois são atividades mais relacionada ao tema em questão.

A administração ocupa-se, segundo Teixeira, Salomão e Teixeira (2010, p. 8) em "reunir e aplicar da melhor forma possível, os recursos disponíveis". À medida que a empresa aumenta sua complexidade, intensificam-se a departamentalização e a especialização das áreas. Devido ao crescimento das organizações foi necessário que a administração de empresas se especializasse em funções. Assim, existem quatro áreas básicas que podem ser identificadas nas empresas. São elas: Marketing, Finanças, Operações e Gestão de Pessoas, conforme demonstrado na Figura 2 (TEIXEIRA; SALOMÃO; TEIXEIRA, 2010, p. 232).

Figura 2 - Áreas básicas da Administração de Empresas.

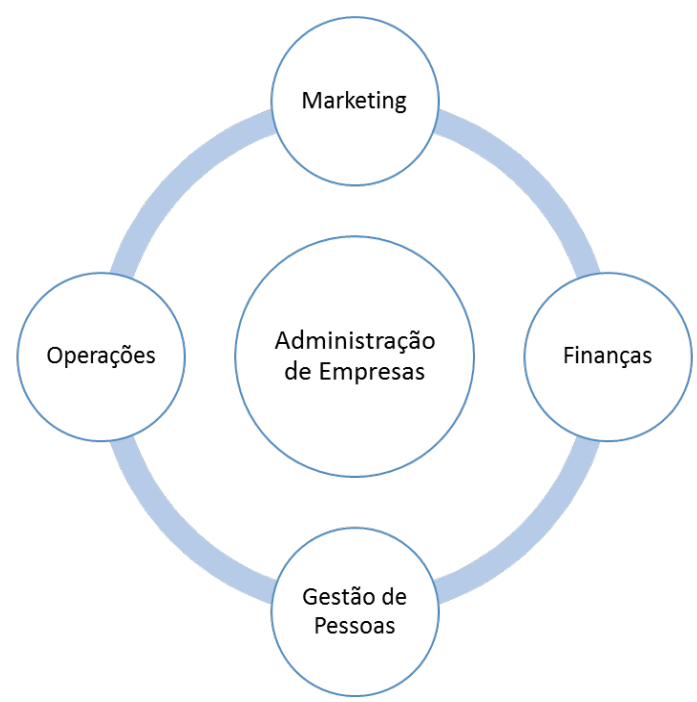

Fonte: elaborada com base em Teixeira, Salomão e Teixeira (2010, p. 232) 
O marketing é definido pela American Marketing Association, (2013) como "a atividade, conjunto de instituições e processos para criar, comunicar, entregar e trocar ofertas que tenham valor para os compradores, clientes, parceiros e para a sociedade". Pode ser entendido como o conjunto de técnicas e ferramentas utilizadas para facilitar as trocas de forma que ofereçam vantagens tanto para a entidade ofertante, quanto para a entidade recebedora. McCarthy, (1976, p. 85) reuniu um conjunto que deu o nome de marketing mix, também conhecido como composto de marketing ou ainda os 4 P's, formado pelos seguintes itens: produto, preço, praça e promoção, representados na Figura 3.

Figura 3 - O composto de marketing.
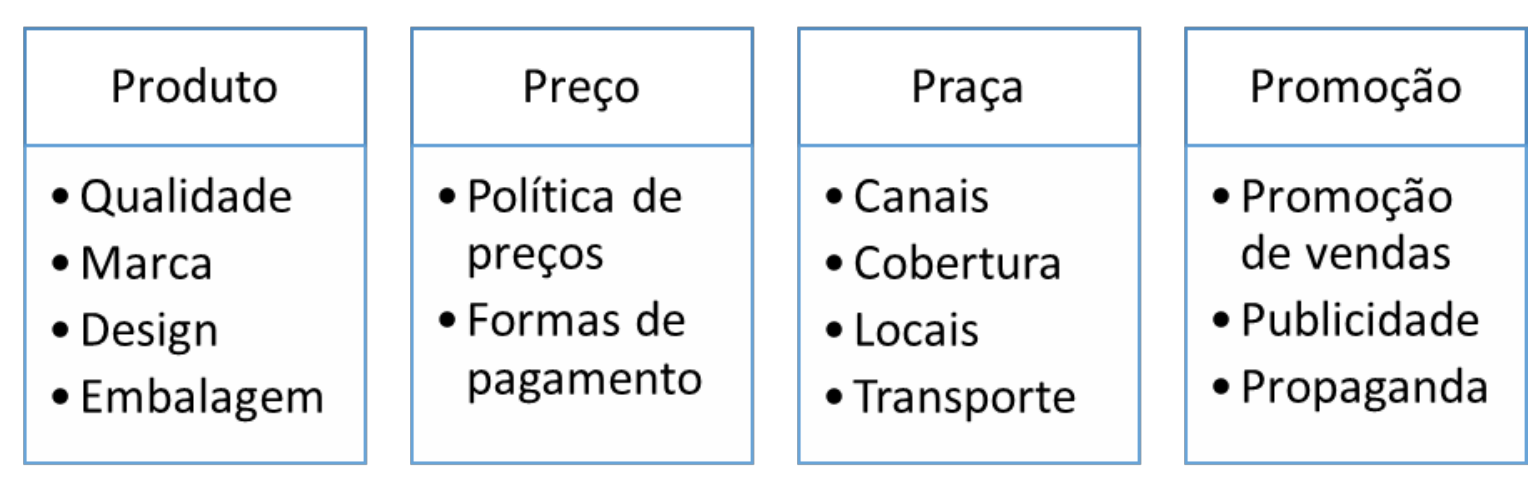

Fonte: elaborada com base em McCarthy (1976, p. 85)

São considerados produtos bens, serviços, experiências, eventos, pessoas, lugares , propriedades, informações ou ideias que serão ofertadas aos consumidores para que se satisfaça a uma necessidade ou desejo (KOTLER; KELLER, 2006, p. 366). A decisão sobre o produto a ser oferecido é composta pela seleção de produtos ou linhas. Ainda faz parte da decisão sobre produto o tamanho, formato, estrutura física, componentes, características, qualidade do desempenho, durabilidade, confiabilidade, estilo, design, embalagem, entre outros atributos (McCARTHY, 1976, p. 86).

As decisões de preços têm como objetivo definir o preço adequado aos produtos ofertados, englobando as políticas e estratégias de precificação. Implica em determinar os custos e despesas da oferta do produto, reação aos concorrentes e a captura do valor percebido pelo cliente (McCARTHY, 1976, p. 86). 
A praça, também é conhecida como canais de marketing. Segundo Coughlan et al., (2002, p. 20) pode ser definida como "conjunto de organizações interdependentes envolvidas no processo de disponibilizar um produto para uso ou consumo". Ou seja, um fabricante geralmente depende de alguns intermediários, como varejistas e atacadistas, para disponibilizar os produtos ao consumidor final.

Por fim, a promoção, ou comunicação, envolve as ferramentas utilizadas para promover, informar, persuadir e lembrar os clientes do produto e da marca ofertada (KOTLER; KELLER, 2006, p. 532). As atividades de marketing mais relacionadas ao Trade Marketing são a comunicação e praça. Dessa forma, nos próximos itens estes tópicos serão discutidos com mais aprofundamento.

\subsubsection{Comunicação de Marketing}

Para Crescitelli e Shimp (2012, p. 8) há diversas ferramentas da comunicação de marketing. Os autores dividem as ferramentas de promoção em três grupos, as tradicionais, complementares e inovadoras. Dentre os elementos de comunicação podemos destacar a propaganda, publicidade, relações públicas, patrocínio, promoções de vendas, marketing direto e venda pessoal como elementos tradicionais. Já o product placement, ações cooperadas, marketing digital, eventos, merchandising, folhetos, marketing de relacionamento e mídia exterior podem ser consideradas como complementares. Por fim, advertainment, marketing viral, buzzmarketing e marketing de guerrilha são considerados ferramentas inovadoras. Os elementos da comunicação, sua principal característica e tipo de mídia mais usual estão representados no Quadro 1.

Quadro 1 - As ferramentas das comunicações de marketing

\begin{tabular}{|l|l|l|}
\hline \multicolumn{1}{|c|}{$\begin{array}{c}\text { Elementos da } \\
\text { Comunicação }\end{array}$} & \multicolumn{1}{|c|}{ Principal Característica } & Tipo de mídia mais usual \\
\hline \multicolumn{1}{|c|}{} & \multicolumn{1}{|c|}{ Tradicionais } \\
\hline Propaganda & Criação de imagem/posicionamento & $\begin{array}{l}\text { Televisão, rádio, revista, jornal, } \\
\text { outdoor e cinema }\end{array}$ \\
\hline Publicidade & Criação de imagem/posicionamento & $\begin{array}{l}\text { Televisão, rádio, revista e } \\
\text { jornal }\end{array}$ \\
\hline Relações Públicas & Imagem na sociedade (opinião pública) & $\begin{array}{l}\text { Televisão, rádio, revista e } \\
\text { jornal }\end{array}$ \\
\hline Patrocínio & Associação de imagem & Mídia indoor e outdoor \\
\hline Promoção de vendas & Estímulo de vendas por meio de benefício extra & Televisão, rádio, revista, jornal \\
\hline
\end{tabular}




\begin{tabular}{|c|c|c|}
\hline & & e ponto de venda \\
\hline Marketing direto & Contato personalizado & Correio, internet e telefone \\
\hline Venda Pessoal & Mensagem personalizada, interativa e modulada & Contato pessoal \\
\hline \multicolumn{3}{|c|}{ Complementares } \\
\hline Product Placement & $\begin{array}{l}\text { Inserção de marca ou produto em programas de } \\
\mathrm{TV} \text {, filmes ou games }\end{array}$ & Televisão e cinema \\
\hline Ações cooperadas & $\begin{array}{lllll}\text { Campanhas conjuntas } & \text { com } & \text { canais } & \text { de } \\
\text { distribuição } & & & & \\
\end{array}$ & Tabloide e encarte \\
\hline Marketing digital & Flexibilidade, rapidez e baixo custo & Internet \\
\hline Eventos & $\begin{array}{l}\text { Contato com público específico (evento } \\
\text { técnico), exposição e valorização de marca } \\
\text { (shows) }\end{array}$ & Feira, congresso e show \\
\hline Merchandising & Comunicação no ponto de venda & Materiais de ponto de venda \\
\hline Folhetos/Catálogos & Informação detalhada & $\begin{array}{l}\text { Material impresso, vídeo e } \\
\text { internet }\end{array}$ \\
\hline $\begin{array}{l}\text { Marketing de } \\
\text { Relacionamento }\end{array}$ & Contato com clientes ativos & Correio, internet e telefone \\
\hline Mídia Exterior & Comunicação ao "ar livre", out-of-home & $\begin{array}{l}\text { Mobiliário urbano, painéis, } \\
\text { imóveis e placas }\end{array}$ \\
\hline \multicolumn{3}{|c|}{ Inovadoras } \\
\hline Advertainment & $\begin{array}{l}\text { Associação de mensagem comercial com } \\
\text { entretenimento }\end{array}$ & Televisão e evento \\
\hline Marketing viral & Disseminação de mensagem on-line & Internet \\
\hline Buzzmarketing & $\begin{array}{l}\text { Colocar um assunto em evidência, torna-lo } \\
\text { relevante por um momento }\end{array}$ & $\begin{array}{l}\text { Boca a boca, internet e mídias } \\
\text { tradicionais }\end{array}$ \\
\hline Marketing de guerrilha & Ações inusitadas para gerar impacto & $\begin{array}{l}\text { Boca a boca, internet e mídias } \\
\text { tradicionais }\end{array}$ \\
\hline
\end{tabular}

Fonte: Crescitelli e Shimp (2012, p. 8)

Analisando o Quadro 1, é possível identificar elementos que proporcionam maior interação entre o fabricante e o canal de distribuição. Estes elementos são: promoções de vendas e merchandising, devido a uma das mídias usuais ser o ponto de venda; a venda pessoal, pois tem como mídia o contato pessoal; as ações cooperadas, uma vez que a característica é efetuar campanhas conjuntas com os canais de marketing; e os eventos, sendo a característica o contato com público específico como em eventos técnicos. Sendo assim, estes itens serão discutidos com mais detalhe no item 2.3.2 funções do Trade Marketing. 


\subsubsection{Canais de Marketing}

As decisões de canais de marketing englobam as formas como os produtos serão disponibilizados aos consumidores. Rosenbloom (2008, p. 23) afirma que a praça foi negligenciada durante algum tempo em comparação aos demais P's do marketing. Entretanto houve uma mudança no papel dos canais desencadeada pelos seguintes fatores:

- O aumento da competição entre as empresas torna mais difícil conquistar vantagem competitiva sustentável;

- A conquista de poder por parte dos intermediários, principalmente dos varejistas;

- Aumento da importância na redução de custos de distribuição;

- Crescimento da empresa baseado no aumento das vendas para atingir maior lucro operacional;

- A ampla utilização de tecnologia, em especial a internet.

As empresas que fazem a intermediação para venda do produto, atacadistas e varejistas, desempenham uma função fundamental para o fabricante, pois por meio deles que o produto é disponibilizado aos consumidores. Coughlan et al., (2002, p. 21) elenca os seguintes aspectos para justificar a existência dos intermediários: (1) Facilitação da busca, reunindo o vendedor e o comprador; (2) Seleção do mix de produtos e categorização, auxiliando a combinação dos produtos ofertados pelos fabricantes; (3) Diminuição do custo de distribuição por gerar rotinas de transações; (4) Redução do número de contatos.

Ocorre redução do número de contatos porque o intermediário diminui os pontos de interação entre os compradores e os fornecedores. As Figuras 4, 5 e 6 demostram a comparação entre a venda direta ao comprador, a venda utilizando um intermediário e a venda com o uso de dois intermediários. É possível notar claramente pelas linhas de contato que as interações diminuem. Na venda direta, representada na Figura 4, são utilizadas 40 linhas de contato. Já com a utilização de um intermediário as linhas de contato são reduzidas para 14, conforme a Figura 5. Caso sejam utilizados dois intermediários, as linhas somam 28 contatos, como apresentado na Figura 6. Ou seja, ocorre uma facilitação no processo de distribuição dos bens. 
Figura 4 - Custos de contato para alcançar o mercado sem intermediários.

$$
\text { Venda Direta }
$$

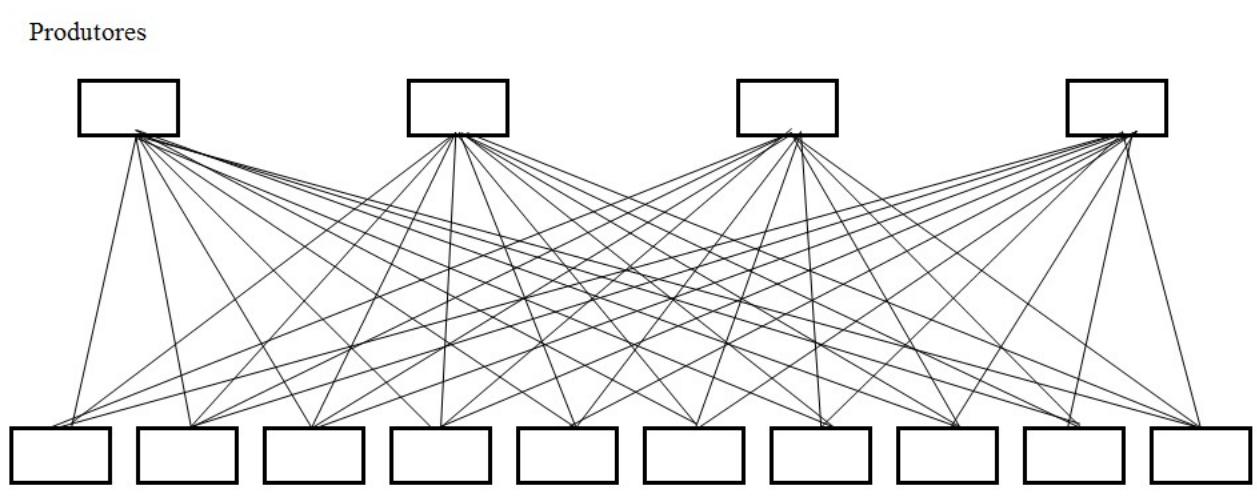

Varejista

Fonte: Coughlan et al. (2002, p. 24)

Figura 5 - Custos de contato para alcançar o mercado utilizando um intermediário.

Venda por meio de um atacadista

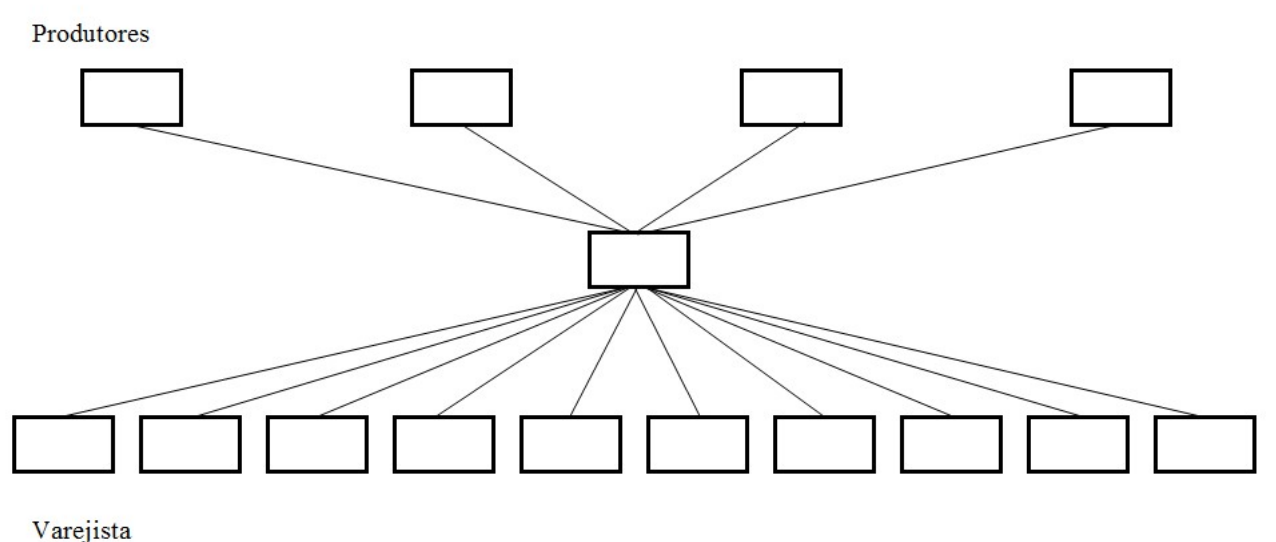

Fonte: Coughlan et al. (2002, p. 24)

Figura 6 - Custos de contato para alcançar o mercado utilizando dois intermediários.

Venda por meio de dois atacadistas

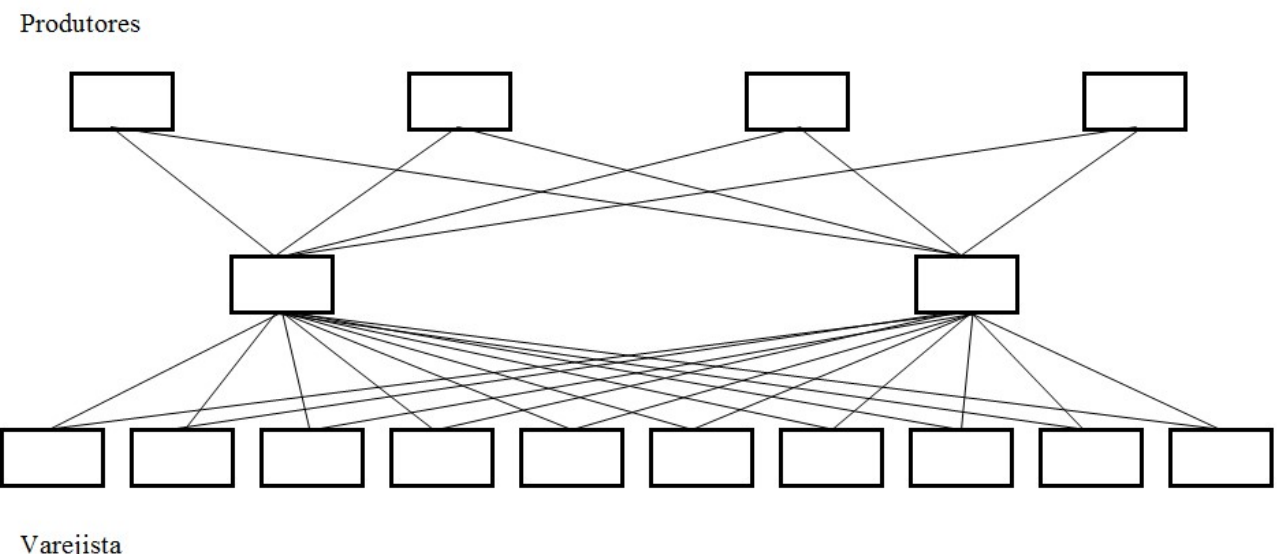

Fonte: Coughlan et al. (2002, p. 24) 
Intermediários do canal de distribuição são empresas independentes que facilitam o contato do produtor com o consumidor. Os intermediários que formam o canal são atacadistas e varejistas. Os atacadistas ocupam-se do armazenamento e revenda de produtos para outras empresas, como os varejistas, por exemplo. Os atacadistas também são chamados de distribuidores ou atravessadores. Seu papel é efetuar grandes compras e revender os produtos em quantidades menores. Além disso, as funções dos atacadistas são fornecer cobertura de mercado, fazer contatos de vendas, manter estoques, processar pedidos, reunir informações de mercado e oferecer suporte ao cliente (ROSENBLOOM, 2008, p. 49).

Já os varejistas são empresas que realizam a revenda de produtos para o consumo pessoal e prestação de serviços relacionados aos bens vendidos. Os serviços prestados pelos varejistas são: o fornecimento da mão-de-obra e do local, o que permite o contato com o consumidor; auxílio na venda do produto com o uso de ferramentas como a venda pessoal e merchandising; divisão de lotes para fornecer quantidades adequadas à necessidade do consumidor; o armazenamento dos produtos; e redução do risco do produtor, pois aceita a entrega antecipada (ROSENBLOOM, 2008, p. 75).

Nas estruturas de canais podem ocorrer conflitos entre os intermediários ou membros dos canais. Os conflitos no canal de marketing ocorrem quando um intermediário acredita que as ações de outros membros impedem a realização de suas metas. Estes conflitos podem ocorrer devido à incongruência de papéis, escassez de recursos, diferenças de percepção, diferenças de expectativas, discordâncias no domínio da decisão e por incompatibilidade de metas (ROSENBLOOM, 2008, p. 115).

Sendo assim, a utilização dos canais de marketing é fundamental para os produtores. Entretanto, existe a necessidade de que os canais e os membros sejam gerenciados para garantir a eficiência da cadeia e para que os produtos cheguem aos consumidores de acordo com as estratégias estabelecidas.

\subsection{Estrutura Organizacional}

Neste item pretende-se discutir como as estruturas organizacionais podem ser formadas, a fim de subsidiar o entendimento da formação de departamentos de Trade Marketing em algumas empresas. Quanto mais complexa uma organização, maior a necessidade de departamentalização. A definição da estrutura organizacional é uma tarefa desafiadora, pois as empresas sofrem alterações constantes em suas estruturas. 
A estrutura organizacional de uma empresa representa a decisão sobre a designação formal de pessoas e tarefas. Contempla a alocação dos indivíduos em departamentos, a apresentação oficial das relações entre os indivíduos e departamentos. Nela estão também representadas as hierarquias, autoridades e responsabilidades. A estrutura tem como objetivo garantir a coordenação de funcionários, funções e áreas e é representada pelo organograma (SCARE, 2008; SHIRAISHI, 2009).

Por meio da estrutura organizacional as empresas podem executar suas estratégias e assim, atingir seus objetivos. Para isso é necessário que a definição da estrutura organizacional seja desenhada com foco no longo prazo e que tenha coerência com os objetivos empresariais almejados (SHIRAISHI, 2009). Segundo Zeyl e Zeyl, (1997, p. 171) a evolução do ambiente de negócios e o aumento da força de concorrência obrigam as organizações a redefinir suas estratégias e, portanto, redefinir também suas estruturas.

Para a construção de uma estrutura organizacional funcional Zeyl e Zeyl, (1997, p. 172) descrevem os seguintes princípios: (1) Estabelecer objetivos claros; (2) Atribuir cada função necessária; (3) Evitar funções duplicadas; (4) Limitar as funções por indivíduo; (5) Agrupar funções próximas e desagrupar funções que não tem ligação; (6) Usar as atribuições com prerrogativas similares para níveis hierárquicos semelhantes; (7) Definir claramente as responsabilidades; (8) Coincidir as responsabilidades e autoridades; (9) Delegar o poder de decisão ao nível mais baixo compatível; (10) Estabelecer um procedimento de comunicação claro; (11) Evitar que haja mais de um chefe por subordinados; (12) Evitar que haja um grande número de níveis hierárquicos; (13) Manter uma organização simples; (14) Evitar alterações excessivas na estrutura e demasiado frequentes.

Os tipos de estruturas organizacionais, segundo Vasconcellos e Hemsley, (2002, p. 3), são as tradicionais, inovativas e matriciais. As estruturas tradicionais são as mais comumente utilizadas, caracterizadas por alto grau de formalização, com unidade de comando estabelecida, especialização de funções, comunicação de forma vertical e departamentalização. Já as estruturas inovativas foram criadas devido à necessidade de flexibilidade na operação da empresa. As características das estruturas do tipo inovativas tem baixo nível de formalização, utilização de formas avançadas para formação de departamentos, multiplicidade de comando, alto grau de diversificação e comunicação de forma horizontal e diagonal (VASCONCELlOS; HEMSLEY, 2002, p. 23). Por fim, as estruturas do tipo matricial são utilizadas principalmente quando existe a necessidade de interação entre as áreas funcionais. Sua principal característica é a utilização de uma forma de estrutura sobre o mesmo membro da organização. 
$\mathrm{Na}$ estrutura tradicional, quanto mais complexa a organização, maior a necessidade de hierarquização. O agrupamento de pessoas em unidades é chamado de departamentalização (VASCONCELLOS; HEMSLEY, 2002, p. 3). A construção de departamentos na empresa depende da amplitude de controle, dos níveis hierárquicos, grau de descentralização, sistemas de comunicação e o grau de formalização da empresa (VASCONCELLOS; HEMSLEY, 2002, p. 4). A formação dos departamentos pode ser definida tendo como base categorizações por função, geografia, processo, clientes, produtos, período e amplitude de controle (VASCONCELLOS; HEMSLEY, 2002, p. 9).

No Quadro 2 estão representados os tipos de departamentalização funcional, geográfica, por processo, clientes, produtos, período e pela amplitude de controle. São apresentados também o conceito de cada tipo, um exemplo, as condições favoráveis para utilização, assim como suas vantagens.

Quadro 2 - Tipos de departamentalização

\begin{tabular}{|c|c|c|c|c|}
\hline $\begin{array}{l}\text { Tipos de } \\
\text { departamen- } \\
\text { talização }\end{array}$ & Conceito & Exemplo & $\begin{array}{l}\text { Condições favoráveis } \\
\text { para utilização }\end{array}$ & Vantagens \\
\hline Funcional & $\begin{array}{l}\text { São agrupadas na } \\
\text { mesma ronidade } \\
\text { pessoas que realizam } \\
\text { atividades dentro de } \\
\text { uma mesma área } \\
\text { técnica }\end{array}$ & $\begin{array}{lll}\text { - } & \text { Depto } & \text { de } \\
& \text { Finança } & \\
\text { - } & \text { Depto } & \text { de } \\
& \text { Marketing } \\
\text { - } & \text { Depto } \\
& \text { hidráulica } & \end{array}$ & 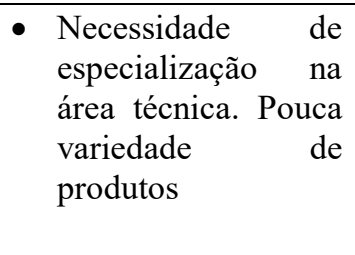 & $\begin{array}{l}\text { - } \\
\text { Especialização na } \\
\text { área técnica. } \\
\text { Eficiente } \\
\text { utilização dos } \\
\text { recursos em cada } \\
\text { área técnica }\end{array}$ \\
\hline Geográfica & $\begin{array}{l}\text { São agrupadas na } \\
\text { mesma unidade } \\
\text { pessoas que realizam } \\
\text { atividades relacionadas } \\
\text { a uma mesma área } \\
\text { geográfica }\end{array}$ & 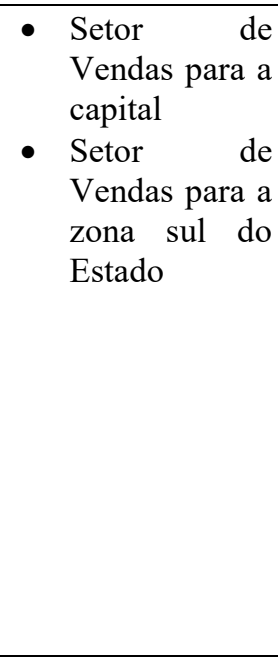 & 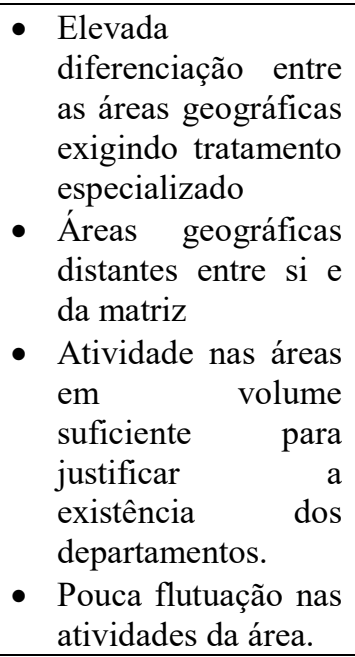 & 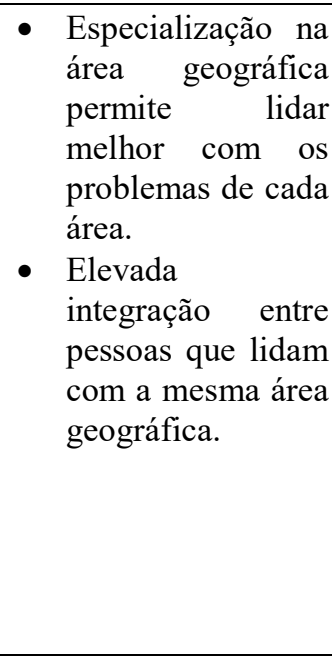 \\
\hline $\begin{array}{l}\text { Por } \\
\text { processo }\end{array}$ & $\begin{array}{l}\text { São agrupadas na } \\
\text { mesma unidade } \\
\text { pessoas que realizam } \\
\text { atividades relacionadas } \\
\text { com uma fase de um } \\
\text { processo produtivo }\end{array}$ & $\begin{array}{lll}\text { - } & \text { Depto } & \text { de } \\
& \text { Fundição } & \\
\text { - } & \text { Depto } & \text { de } \\
& \text { Usinagem } & \\
\text { - } & \text { Depto de } \\
& \text { Montagem } & \\
\text { - } & \text { Depto de } \\
& \text { Pintura } & \end{array}$ & $\begin{array}{l}\text { - Alta diferenciação } \\
\text { entre as fases do } \\
\text { processo; } \\
\text { - Necessidade de } \\
\text { técnicas da mesma } \\
\text { fase ficarem juntas } \\
\text { para permitir ajuda } \\
\text { mútua; } \\
\text { - Troca de }\end{array}$ & \begin{tabular}{ll} 
- & \multicolumn{2}{l}{ Especialização nas } \\
várias fases do \\
processo. \\
- \\
Elevada \\
integração entre \\
pessoas que \\
trabalham numa \\
determinada fase
\end{tabular} \\
\hline
\end{tabular}




\begin{tabular}{|c|c|c|c|c|}
\hline & & & $\begin{array}{l}\text { experiências } \\
\text { aprimoramento } \\
\text { técnico. }\end{array}$ & \\
\hline Por clientes & $\begin{array}{l}\text { São agrupadas na } \\
\text { mesma unidade } \\
\text { pessoas que estão } \\
\text { relacionadas com o } \\
\text { mesmo tipo de cliente }\end{array}$ & $\begin{array}{l}\text { Depto de } \\
\text { Vendas para } \\
\text { Clientes } \\
\text { Industriais } \\
\text { - Depto de } \\
\text { Vendas ao } \\
\text { consumidor }\end{array}$ & 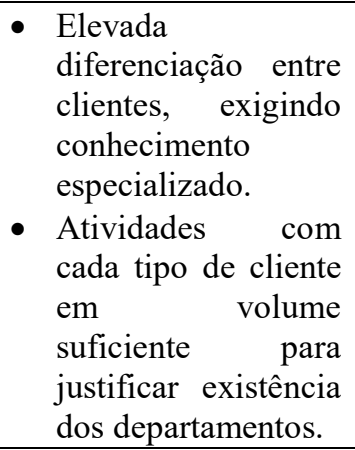 & $\begin{array}{l}\text { - Especialização no } \\
\text { tratamento de cada } \\
\text { tipo de cliente. } \\
\text { - Elevada } \\
\text { integração entre as } \\
\text { pessoas que lidam } \\
\text { com um mesmo } \\
\text { tipo de cliente. }\end{array}$ \\
\hline $\begin{array}{l}\text { Por } \\
\text { produtos }\end{array}$ & $\begin{array}{l}\text { São agrupadas na } \\
\text { mesma unidade } \\
\text { pessoas que estão } \\
\text { relacionadas com o } \\
\text { mesmo produto ou } \\
\text { linha de produtos. }\end{array}$ & $\begin{array}{ll}\text { - } & \text { Depto de } \\
\text { Carros de } & \\
\text { passeio } & \\
\text { - } & \text { Depto de } \\
& \text { Caminhões }\end{array}$ & 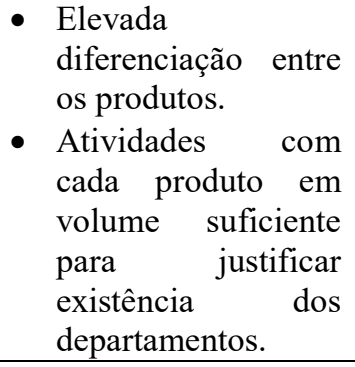 & 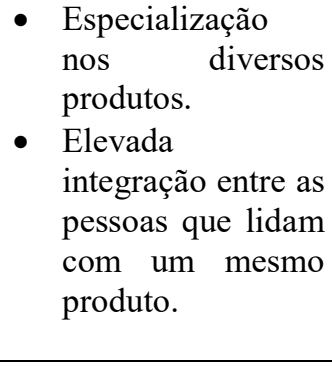 \\
\hline Por período & $\begin{array}{l}\text { São agrupadas na } \\
\text { mesma unidade } \\
\text { pessoas que trabalham } \\
\text { no mesmo período }\end{array}$ & 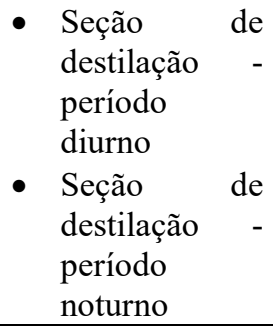 & $\begin{array}{l}\text { - Mesma atividade é } \\
\text { realizada por mais } \\
\text { de um turno de } \\
\text { trabalho. }\end{array}$ & $\begin{array}{l}\text { Neste caso não cabe } \\
\text { discutir vantagens } \\
\text { deste tipo de } \\
\text { departamentalização } \\
\text { visto que não há } \\
\text { alternativas. }\end{array}$ \\
\hline $\begin{array}{l}\text { Pela } \\
\text { amplitude } \\
\text { de controle }\end{array}$ & $\begin{array}{l}\text { São agrupadas na } \\
\text { mesma unidade o } \\
\text { número máximo de } \\
\text { pessoas que o chefe } \\
\text { pode supervisionar } \\
\text { eficientemente. Os } \\
\text { demais formarão outra } \\
\text { unidade, e assim } \\
\text { sucessivamente. }\end{array}$ & $\begin{array}{lll}\text { - } & \text { Unidade } & \text { de } \\
& \text { Corte I } & \\
\text { - } & \text { Unidade } & \text { de } \\
& \text { Corte II } & \\
\text { - } & \text { Unidade } & \text { de } \\
& \text { Corte III } & \end{array}$ & $\begin{array}{lr}\text { - } & \text { Grande número de } \\
\text { pessoas } & \text { que } \\
\text { realizam a } & \text { mesma } \\
\text { atividade. } & \text { As } \\
\text { unidades } & \text { são } \\
\text { constituídas } & \\
\text { considerando } & \text { o } \\
\text { limite do chefe para } \\
\text { supervisionar. }\end{array}$ & $\begin{array}{l}\text { Neste caso não cabe } \\
\text { discutir vantagens } \\
\text { deste tipo de } \\
\text { departamentalização } \\
\text { visto que não há } \\
\text { alternativas. }\end{array}$ \\
\hline
\end{tabular}

Fonte: Vasconcellos e Hemsley (2002, p. 15).

\subsubsection{Estrutura Organizacional de Marketing}

A Estrutura ou Organização de Marketing é uma das principais decisões e atividades do marketing. A empresa deve ter uma estrutura de marketing "para executar as atividades de forma que os responsáveis tirem o máximo de proveito das técnicas disponíveis ou que descubram novas técnicas" (CAMPOMAR, 1984).

As mudanças no ambiente de negócios, como instabilidade nos mercados financeiros, avanços tecnológicos e relacionados à tecnologia da informação e aumento das exigências dos 
consumidores e dos clientes, assim como as restrições causadas pela degradação do meio ambiente, afetam as empresas e suas estruturas (SHIRAISHI, 2009). Ainda segundo Shiraishi (2009) “as estruturas de marketing são subordinadas às estratégias da empresa”.

O tipo de estrutura organizacional de marketing está relacionado com o ambiente no qual a empresa está inserida. Os ambientes menos turbulentos favorecem as estruturas tradicionais. Por outro lado, empresas que estão em ambientes mais conturbados necessitam ter estruturas mais inovativas, ou seja, organizadas em matrizes, esquemas orgânicos ou em forma de rede (SHIRAISHI, 2009).

Outro ponto relevante discutido por Shiraishi (2009) é que

"Na medida em que as estratégias da empresa se tornam cada vez mais competitivas, as atividades de marketing migram dos departamentos estabelecidos em bases funcionais para serem compartilhadas e executadas por outras estruturas da organização".

Isto ocorre em empresas orientadas para o mercado e que encontram-se em ambientes extremamente competitivos. Cabello et al. (2014) discute a relação entre a orientação de marketing e a estrutura organizacional. Os autores afirmam que a orientação para o mercado é afetada pela estrutura, sendo que esta pode ser um facilitador ou uma barreira da introdução à orientação para mercado.

Para Kotler e Keller, (2006, p. 703) os departamentos de marketing podem ser organizados de diversas formas, como por função, geografia, pela linha de produtos, pela marca ou por mercado. Já a estrutura de marketing pode ser organizada matricialmente, por corporação ou por divisão.

Para Ames, (1971) na década de 60 as empresas responderam ao crescimento de mercado e das linhas de produto adicionando em suas estruturas de marketing gerentes de produtos ou gerentes de mercado. O gerente de produto faz parte da estrutura quando a empresa tem múltiplos produtos num mercado comum, além de utilizar os mesmos canais e o mesmo grupo de consumidores. Já os gerentes de mercado são usados na situação inversa, ou seja, quando a empresa precisa desenvolver diferentes mercados para um produto. Neste caso o foco no desenvolvimento de mercado é maior do que o foco em oferecer produtos para o mercado (AMES, 1971).

Alguns autores defendem um tipo de abordagem para a estrutura de marketing, apresentando a visão de que ter um departamento como uma função separada é obsoleto. Neste caso, o marketing estaria disperso na organização e a satisfação do cliente deveria ser o objetivo de cada funcionário (WEBSTER, 1994, p. 206 apud CABELLO et al., 2014). Considerando que dentre as funções e atividades de marketing está o composto de marketing, 
com as decisões de preço, praça, produto e promoção, existe a necessidade de um departamento responsável por estas decisões. Caso não existisse um departamento de marketing, caberia a todos a definição de preço, por exemplo, o que não seria possível. Entretanto, conforme colocado por Achrol, (1991) a empresa como um todo pode ter como objetivo a satisfação do cliente e os departamentos podem colaborar fornecendo dados para alimentação do sistema de informação de marketing.

Tozzi (2014) discute a holocracia e aponta que existe a necessidade de que as estruturas das empresas se tornem mais igualitárias devido a mudanças no ambiente cultural. Os funcionários desejam ser ouvidos e ter suas necessidades individuais supridas. Assim, uma das formas encontradas pelas empresas para se adequarem a este novo cenário é a eliminação da hierarquia. Dutra, (2014) explica que o chefe não é eliminado da estrutura neste modelo: o que ocorre, na verdade, é a formação de grupos semiautônomos, os quais se reportam a um gestor, que gerencia em torno de duzentas pessoas. Além disso, existem funções e responsabilidades rigorosamente definidas para cada indivíduo.

Um exemplo de alteração de estrutura ocorreu na empresa Procter \& Gamble ${ }^{\circledR}$ : todos os cargos de diretores de marketing foram alterados para diretores de marca (NEFF, 2014). A Procter \& Gamble ${ }^{\circledR}$ anunciou em fevereiro de 2014 o novo desenho de sua estrutura e a área de marketing foi batizada como gerenciamento de marcas. Outras funções também ganharam novos nomes, como o departamento de pesquisa de marketing, que foi transformado em conhecimento do consumidor e do marketing. O que pode ser verificado em relação a este tipo de alteração na estrutura organizacional é a mudança no nome da função. Porém o chamado job description, a descrição do cargo e funções, parece permanecer inalterada. $\mathrm{Ou}$ seja, os funcionários desempenham as mesmas atividades, entretanto, seus cargos receberam novas nomenclaturas.

Outra questão relacionada a estrutura é a formação de estruturas informais. Estas são criadas por relações entre os funcionários da empresa. Em alguns casos a estrutura informal acaba por sobrepor o organograma oficial. A estrutura informal é chamada de personograma por Campomar (2013). Para Scare (2008) o personograma afeta principalmente a área de marketing e é caracterizado pela influência de interesses e poderes pessoais.

É possível notar que na área de marketing ocorrem diversas alterações na estrutura organizacional. As empresas têm liberdade de empregar a nomenclatura que desejam para denominar os cargos, o que dificulta o entendimento das atribuições das posições na estrutura. Assim, a descrição do cargo com as funções que serão desenvolvidas pelos indivíduos é uma ferramenta essencial. 
Outra causa de alterações na estrutura é possíveis mudanças no ambiente competitivo em que a empresa está inserida, pois algumas áreas tornam-se mais necessárias e ganham mais destaque na estrutura. Todos estes fatores influenciam a criação de novas áreas e departamentos, como o Trade Marketing, que devem ser melhor estudados na academia.

\subsubsection{O Trade Marketing na estrutura organizacional}

As empresas fabricantes de produtos tiveram que, ao longo do tempo, adaptar sua organização às mudanças no ambiente de negócios. A mudança na relação de poder entre fabricantes e varejistas, principalmente, faz com que as empresas necessitem de uma nova abordagem que pode incluir alterações em sua estrutura (RANDALL, 1994, p. 112).

Não se sabe ao certo quando nem onde surgiram os primeiros departamentos de Trade Marketing. Entretanto Cônsoli e D'Andrea, (2010, p. 33) afirmam que os primeiros departamentos tiveram origem na Europa, na década de 1980. Já o nome Trade Marketing foi criado pela empresa Colgate-Palmolive ${ }^{\circledR}$. No Brasil, a Kolynos ${ }^{\circledR}$ criou, em 1995, um departamento de Trade Marketing que seria responsável por efetuar parecerias com o varejista. Para isso, o departamento deveria fornecer informações para a equipe de vendas, criar estratégias de atuação segmentada, efetuar a promoção, fazer o gerenciamento de categorias e desenvolver novos clientes.

Para entender o surgimento dos departamentos de Trade Marketing primeiro é necessário compreender como são as estruturas sem o departamento. Nas empresas com estruturas tradicionais adotaram-se departamentos de vendas e departamentos de marketing (MOTTA; SANTOS; SERRALVO, 2008, p. 101). O marketing tem como objetivos entender o consumidor e criar marcas fortes. Para isso, este departamento decide acerca do composto de marketing. Randall (1994, p. 118) destaca que o departamento de vendas tem como objetivo efetuar as vendas da empresa e para isso tem como tarefas construir e manter relacionamento com os varejistas, negociar, efetuar pedidos e reportar as informações obtidas com clientes. Na Figura 7 está representada a estrutura organizacional tradicional com departamentos de marketing e vendas, sendo o departamento de marketing organizado com gerentes de produtos ou marcas, enquanto que o departamento de vendas é composto por gerentes de contas-chave e/ou região geográfica. 
Figura 7 - Organização Tradicional

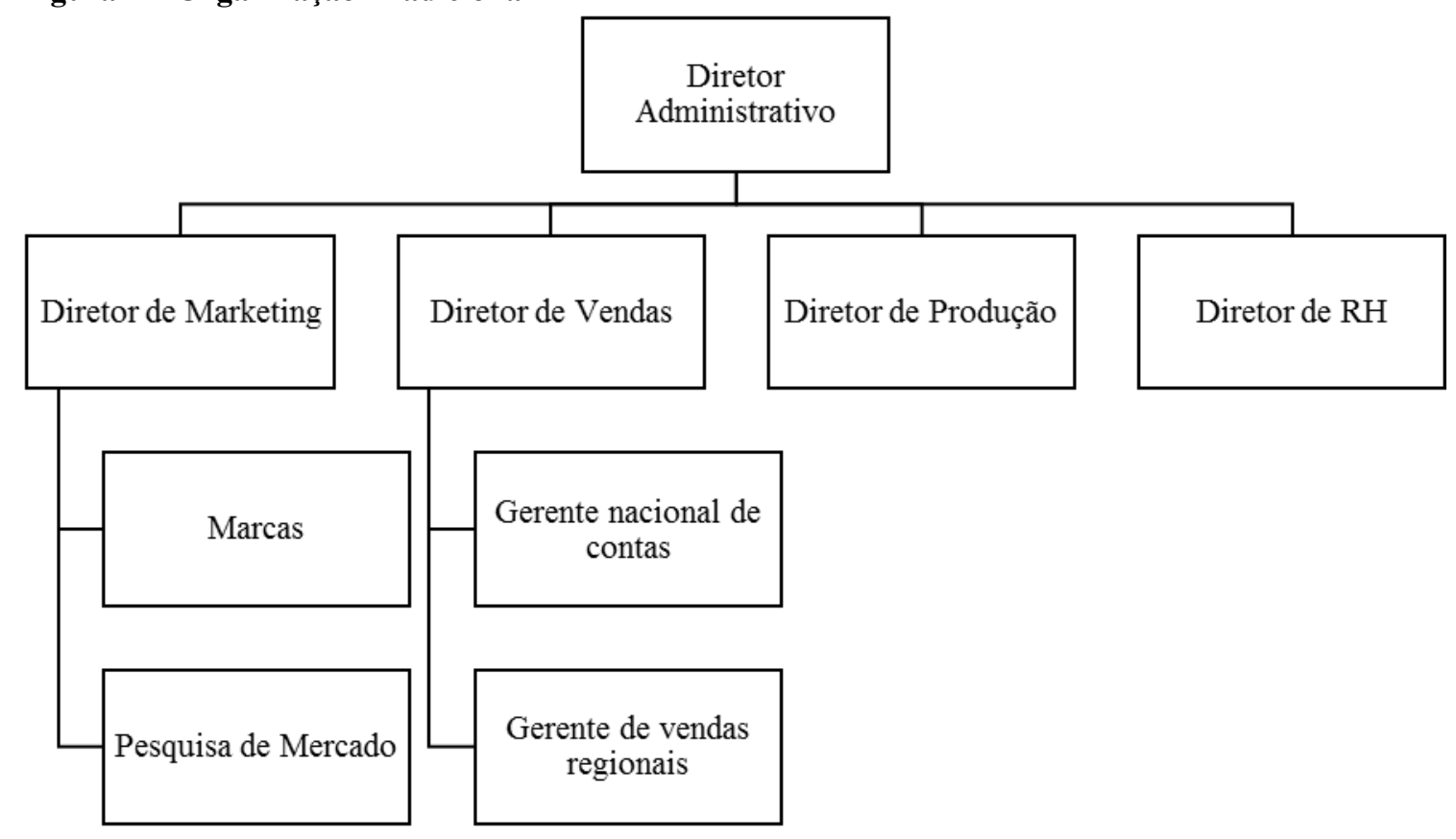

Fonte: Randall, (1994, p. 127)

No modelo de estrutura apresentado pela Figura 7 o relacionamento com o varejista é desenvolvido pelo departamento de vendas (MOTTA; SANTOS; SERRALVO, 2008, p. 112). Neste contexto outra função aparece na estrutura organizacional: o promotor de vendas. $\mathrm{O}$ promotor de vendas é o indivíduo contratado pela indústria para efetuar as ações de promoção de vendas e merchandising no canal varejista. Assim, esta função ficou atrelada ao departamento de vendas ou marketing.

A discussão sobre o cargo de promotor de vendas no Brasil é complexa. Esta função muitas vezes não está presente nas estruturas organizacionais, pois este profissional é contratado por meio de terceirização de mão-de-obra. Um Projeto de Lei que regulamenta as profissões de Promotor de Vendas e de Demonstrador de Mercadorias está em tramitação na câmara dos deputados (BRASIL, 2009a). Segundo o Projeto, são considerados promotores de vendas e demonstradores de mercadorias aqueles que:

"Exerçam, em caráter habitual, função remunerada e exclusiva de promoção de vendas e demonstração de mercadorias, como empregados contratados diretamente pelas indústrias ou por empresas prestadoras de serviços contratadas por estas, para prestarem serviços no âmbito dos estabelecimentos de comércio atacadista ou varejista” (BRASIL, 2009a).

O Projeto de Lei prevê a possibilidade de terceirização do profissional, porém o Tribunal Superior do Trabalho permite a terceirização de funcionários nas empresas, apenas para atividades-meio (BRASIL, 2011). O Ministério do Trabalho, concluiu que os promotores 
de venda deveriam ser vinculados ao varejo e não a indústria ou agências, pois exercem atividade-fim como a reposição de produtos, organização e abastecimento de gondolas, precificação de produtos. Assim, a figura do promotor de vendas no Brasil ainda necessita mais estruturação. Os varejistas utilizam os promotores de vendas cedidos pelos produtores, dos bens revendidos, para outras atividades que não estão relacionadas com a promoção de vendas do fabricante que os contratou. Por este motivo é gerada muita discussão sobre o cargo. As funções e atribuições do promotor de vendas são:

"Profissionais qualificados em nível médio que, sob supervisão direta ou indireta do contratante, executam ações:

I - Planejar vendas;

II - Acompanhar clientes no pós-venda;

III - Contatar áreas internas da empresa;

IV - Empregar técnicas de atendimento adequadas que proporcione a satisfação do cliente;

V - Elaborar relatórios de promoções.

VI - Atuar na reposição e exposição de mercadorias" (BRASIL, 2011).

A exposição inadequada dos produtos e falta de espaço nas prateleiras dos varejos devido ao excesso de marcas desencadearam mais foco nas promoções de vendas e merchandising. Com o aumento da importância destas ações para a indústria e com a alteração no ambiente de negócios, surge a necessidade de alteração na estrutura organizacional (MOTTA; SANTOS; SERRALVO, 2008, p. 111). Cria-se, então, o Trade Marketing: uma área responsável, não somente pela promoção de vendas no canal de distribuição, mas também pelo relacionamento com o canal, desenvolvimento de novos canais, entre outras atividades que serão discutidas no item 2.3.2 Funções do Trade Marketing. Outros fatores contribuíram para o destaque das promoções de vendas e merchandising, como a concentração e aumento de poder dos varejistas, mais conhecimento em relação ao comportamento do shopper, o avanço da tecnologia no varejo, a utilização de técnicas de Efficient Consumer Response (ECR) e gerenciamento por categorias (CÔNSOLI; D'ANDREA, 2010, p. 33). Para Alvarez (2008, p. 81), devido às dificuldades enfrentadas para a venda de produtos e à força dos varejistas, transferiu-se para a indústria os custos de divulgação dos produtos. A partir das atividades de merchandising há uma evolução natural para a implementação de departamentos de Trade Marketing.

Segundo Alvarez, (2008, p. 97) o Trade Marketing interage com diversos setores, tanto na empresa quanto no cliente. No início de sua implantação, o Trade Marketing pode ser relacionado ao setor de vendas, especialmente quando seu foco principal são ações de 
merchandising e outras ações no ponto de venda. Alvarez, (2008, p. 97) ainda destaca que, ao ser subordinado à vendas, o Trade Marketing torna-se muito operacional, pois está orientado para a venda. Assim, o setor de marketing entende-o como uma extensão do departamento comercial.

A Figura 8 demonstra a estrutura organizacional com a área de Trade Marketing subordinada ao departamento de vendas.

Figura 8 - Organização tradicional com inserção do departamento de Trade Marketing subordinado ao departamento de vendas

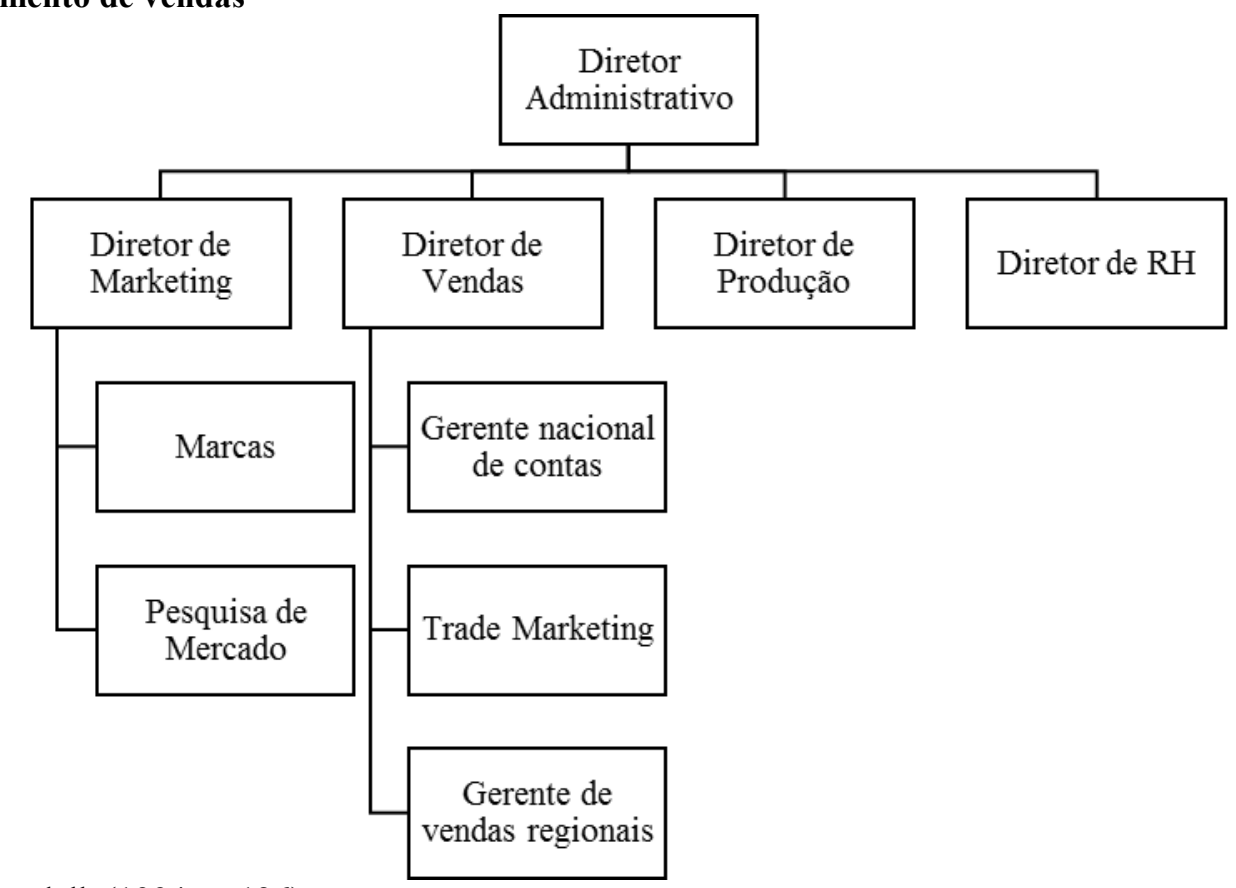

Fonte: Randall, (1994, p. 126)

Quando o Trade Marketing está subordinado ao setor de marketing a tendência é que as ações desenvolvidas sejam focadas no consumidor final no ponto de venda, sem auxiliar as negociações com o canal. Para Motta, Santos e Serralvo (2008, p. 103) essa estrutura pode ser utilizada quando o departamento de marketing tem mais força junto à direção da empresa ou quando o departamento de marketing apresenta grande resistência em dividir o orçamento com outras diretorias. Neste caso, o Trade Marketing é visto como uma extensão do departamento de marketing pela área de vendas que não desenvolve trabalhos em parceria com o Trade Marketing (ALVAREZ, 2008, p. 98).

A Figura 9 demonstra a estrutura organizacional tradicional com a área de Trade Marketing subordinada ao departamento de marketing. 
Figura 9 - Organização tradicional com inserção do departamento de Trade Marketing subordinado ao departamento de marketing

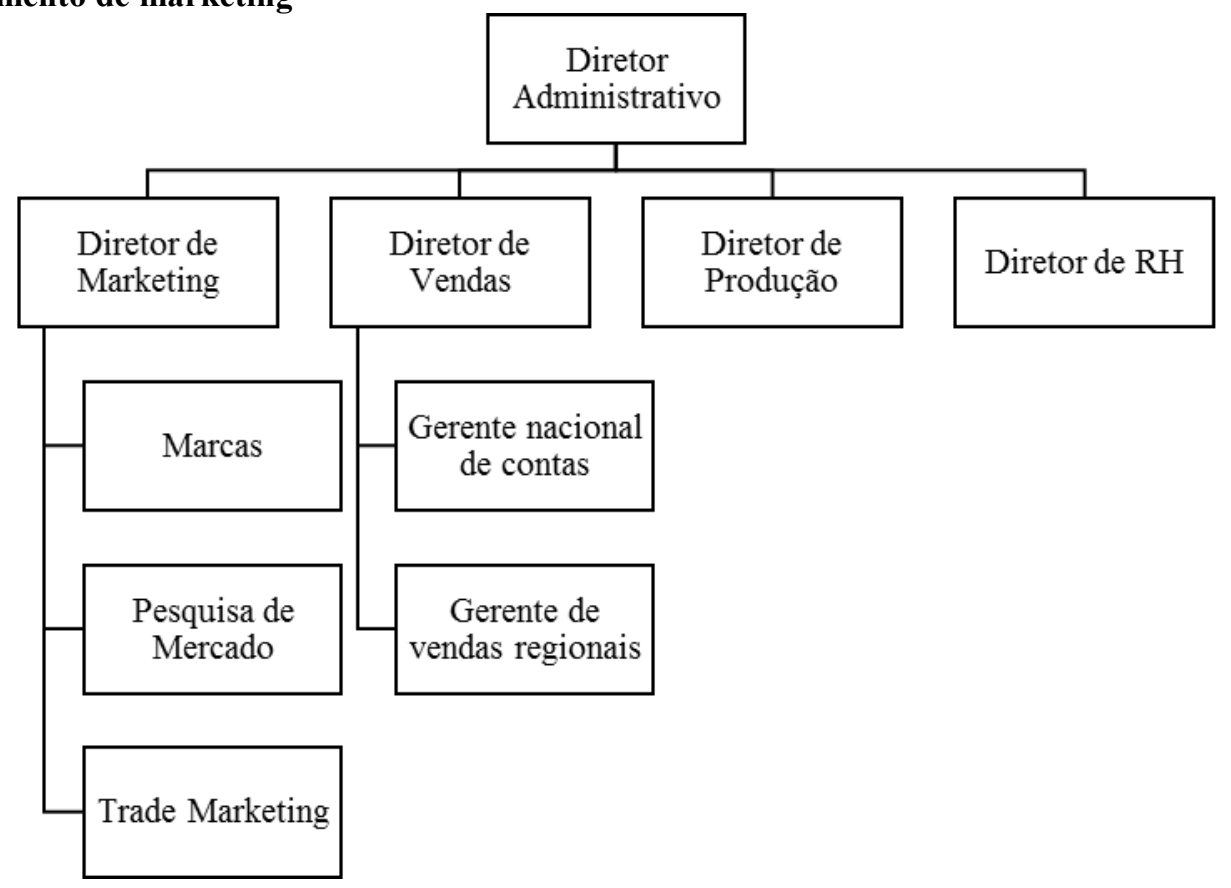

Fonte: Motta, Santos e Serralvo (2008, P. 94)

Alvarez (1999) defende que o Trade Marketing deve ser encarado como uma área que integra o departamento de marketing e vendas, obtendo sinergia entre os dois setores. Por esse motivo, sugere que a função seja independente de Marketing ou Vendas, como um departamento a parte, cuja função é integrar as atividades de marketing e vendas. Zeyl e Zeyl (1997, p. 176) também compartilha a visão de que o departamento de Trade Marketing deve ser independente de outros departamentos.

$\mathrm{Na}$ Figura 10, a estrutura organizacional tradicional está representada com o departamento de Trade Marketing independente dos departamentos de vendas e marketing. 
Figura 10 - Organização tradicional com departamento de Trade Marketing

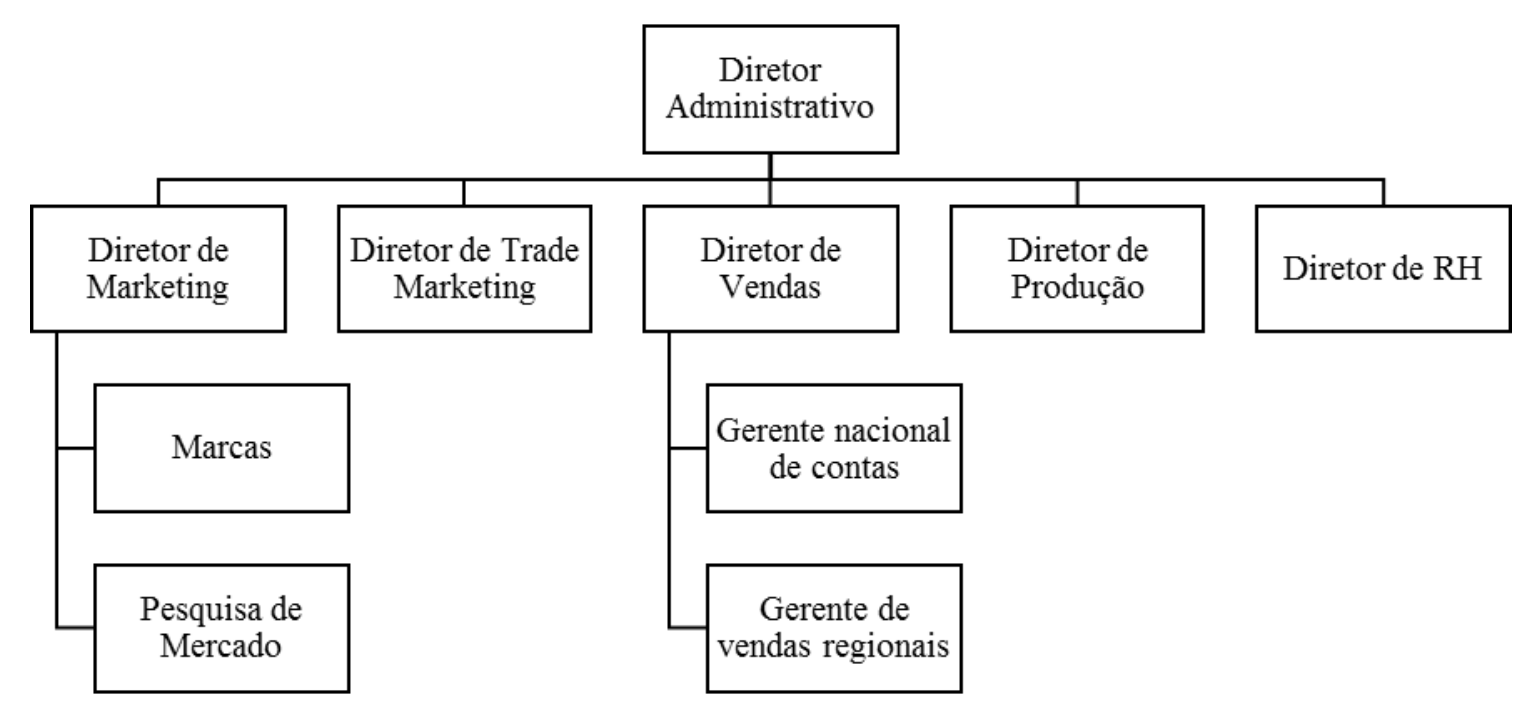

Fonte: Randall, (1994, p. 127)

Segundo Motta, Santos e Serralvo, (2008, p. 103) em uma pesquisa sobre a estrutura de Trade Marketing em empresas no Brasil, 65\% dos departamento de Trade Marketing estão subordinados ao departamento de vendas; em 25\% das empresas o departamento de Trade Marketing está subordinado ao departamento de marketing; e em 10\% existe um departamento independente de Trade Marketing.

Já para Cônsoli e D'Andrea (2010, p. 157), o departamento de Trade Marketing ainda pode ser estruturado de acordo com os canais de distribuição atendidos, sendo neste caso segmentado pela região geográfica da equipe de vendas, ou seguindo a estrutura de agrupamentos de produtos, ou ainda uma estrutura que contempla os canais de distribuição e o agrupamento de produtos da empresa. Para que esta decisão seja tomada, deve-se levar em conta a complexidade e a dimensão da empresa. Nestes casos o departamento de Trade Marketing também tem uma complexidade maior, sendo necessário este tipo de estruturação.

De acordo com Alvarez (2008, p. 82), o processo de implantação do Trade Marketing pode ocorrer em cinco fases: fase de vendas, fase de marketing, fase de cliente, fase de resultado financeiro e fase do desenvolvimento de negócios. $\mathrm{Na}$ fase de vendas o departamento está voltado para o suporte ao departamento comercial, atendendo às demandas dos clientes e de vendas. As ações são pensadas a curto prazo, não apresentam orçamento próprio e suas atividades estão focadas em ações de merchandising e valorização do cliente. 
Já a fase de marketing, tem como característica apoiar às atividades do departamento de marketing e, assim, suas principais ações têm como objetivo reposicionamento de produtos ou aumento da visibilidade no ponto de venda, utilizando merchandising e promoções de vendas e complementando as atividades do marketing. A área ainda pode trazer informações sobre as ações dos concorrentes junto aos canais, as quais são focadas tanto no curto quanto no longo prazo. O orçamento pode ser uma parte do orçamento do departamento de marketing ou de vendas.

Na próxima fase, a fase do cliente, a área de Trade Marketing tem foco na otimização da performance do produto no canal. Apoia tanto à área de vendas quanto à área de marketing. Seu perfil de ação é mais proativo, pois propõe ações para implementar nos clientes. Além disso, a área ainda pode analisar informações do mercado e do ponto de venda, avaliar o giro de produtos, participar na formação de preços e apoiar à implementação do gerenciamento de categorias.

$\mathrm{Na}$ fase chamada resultado financeiro há uma preocupação com os custos de servir e da rentabilidade obtida com os clientes. Busca-se ainda a otimização do merchandising. As ações da área englobam orientações acerca do posicionamento e da margem determinada pelo marketing.

Por fim, a fase de desenvolvimento de negócios tem como foco o desenvolvimento de novos negócios tendo por base as informações do ponto de venda. Nesta fase, o Trade Marketing atua sugerindo modificações no portfólio de produtos de acordo com as informações obtidas no varejo, organiza e analisa informações sobre o comportamento do consumidor no ponto de venda e auxilia as negociações do departamento comercial com os clientes. Além disso, também efetua planos de desenvolvimento dos negócios ou de novas oportunidades e cria estratégias de produtos ou canal, buscando diminuir os conflitos entre os canais.

A Figura 11 apresenta a evolução das fases de implantação do Trade Marketing proposta por Alvarez (2008, p. 84), assim como as principais características de cada uma e a visão de curto ou longo prazo de acordo com a fase. 
Figura 11 - Evolução das fases de implantação do Trade Marketing

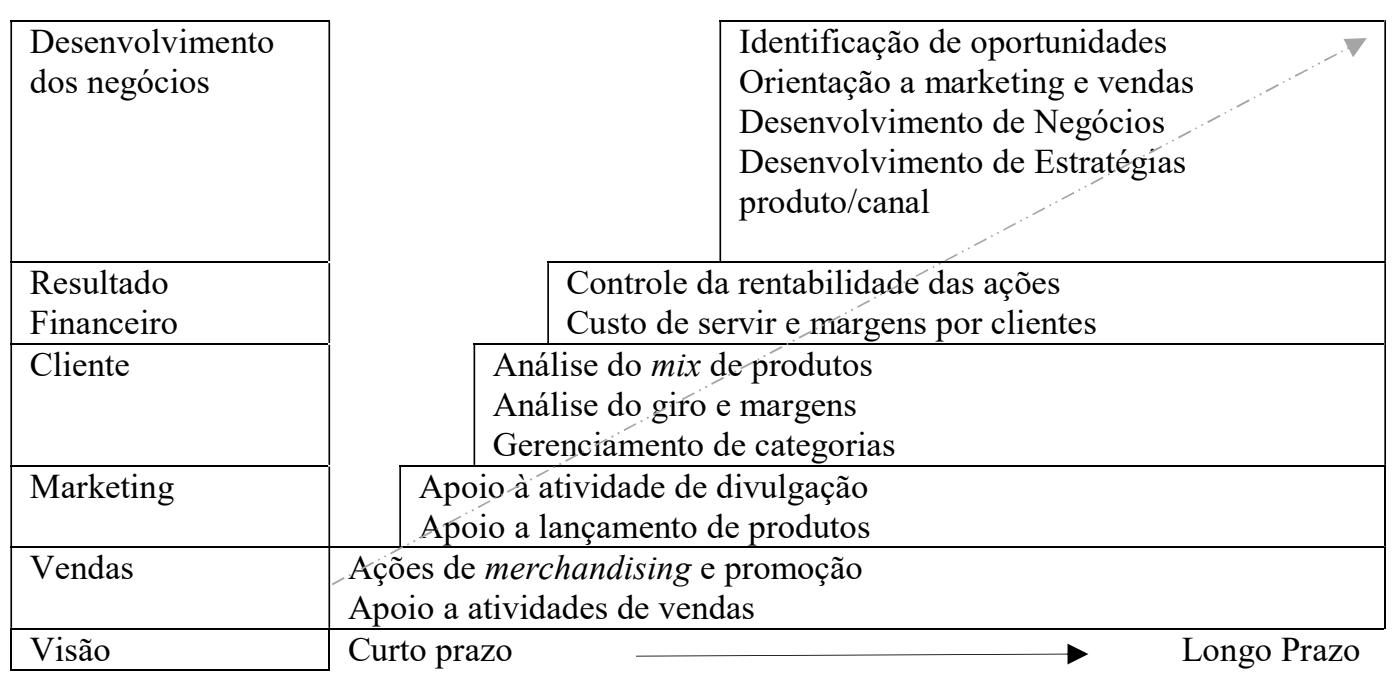

Fonte: Alvarez (2008, p. 84)

Para Cônsoli e D'Andrea, (2010, p. 53) a área de Trade Marketing pode ter alguns enfoques distintos, sendo eles estratégico, tático ou operacional: no enfoque estratégico, o Trade Marketing preocupa-se com o planejamento de vendas e canais; o enfoque tático tem sua atenção concentrada em promoções no ponto de venda como um investimento alternativo para a marca; por fim, o enfoque operacional tem como principal objetivo desenvolver ações de merchandising e promoção de vendas.

Existem diversas formas para que as empresas possam dispor e organizar as áreas de Trade Marketing em suas estruturas. Entretanto, ainda não sabe-se ao certo qual é a melhor forma de estruturar o Trade Marketing. Além disso, nota-se que a literatura comenta sobre níveis diferentes de evolução nos departamentos de Trade Marketing. A implantação de departamentos de Trade Marketing ocorre em fases. O desenvolvimento das suas atividades deve ser compatível com as necessidades da empresa.

\subsection{Trade Marketing}

No cenário atual, o ambiente de negócios é composto por consumidores que estão mais informados, que a efetividade das propagandas é menor e que a força do varejo é maior. Além disso, a competição é alta e há grande regulamentação por parte do governo. Randall (1994, p. ix) afirma que as empresas fabricantes tem apenas duas formas de ter sucesso neste contexto 
turbulento: a primeira é construir e manter marcas fortes e a segunda é proporcionar excelentes serviços para os clientes varejistas.

Sendo assim, o relacionamento com o canal de distribuição é essencial, pois permite a formação de parcerias. A Associação Brasileira De Anunciantes (2012), afirma que:

“A mais importante característica do Trade Marketing é a criação de um relacionamento entre fornecedor e cliente, que vai além da negociação. A prioridade da área não são as questões comerciais e sim o planejamento estratégico a médio e longo prazo".

A literatura sobre Trade Marketing é escassa e o tema é relativamente novo quando comparado a outros temas de marketing. Mais recentemente, Longaray e Ensslin (2015) realizaram um estudo sobre o modelo de decisão multicritério para a gestão do Trade Marketing. Já, Assis et al. (2013) analisa, por meio de estudo de caso, como as ações de Trade Marketing foram elaboradas na introdução da marca Tresemmé no Brasil. Outro estudo identifica os atributos que dificultam e contribuem para que a área de Trade Marketing esteja adequada à estratégia de negócio das empresas por meio de um questionário respondido por executivos do setor de bens de consumo (NETO; MACEDO-SOARES; PITASSI, 2011).

Alguns estudos discutem o conceito de Trade Marketing e suas aplicações como Dupuis e Tissier-Desbordes (1994) e Alvarez (1999). Em outros são discutidas as estruturas organizacionais de Trade Marketing (MOTTA, 2007).

\subsubsection{O conceito de Trade Marketing}

O conceito de Trade Marketing possui diversas visões na literatura. Para Fornari (1986, 1988) apud Dupuis e Tissier-Desbordes (1994) o Trade Marketing tem quatro objetivos: verificar o potencial de crescimento dos canais e dos clientes por canal; avaliar a relação da força entre produtores e distribuidores, estabelecendo uma negociação equilibrada; elaborar um programa de ação por canal e por cliente; e buscar a melhora da rentabilidade por canal e cliente, otimizando o investimento da empresa. Fornari (1986) apud Dupuis; TissierDesbordes (1996) define o Trade Marketing como ações cujos propósitos são identificar, planejar e gerenciar, otimizando a utilização dos recursos da empresa e obtendo vantagem competitiva sustentável. A definição proposta é ampla, podendo ser aplicada a diversas áreas e até mesmo ao próprio marketing. Por outro lado, o autor introduz o Trade Marketing como uma ferramenta para criar vantagem competitiva para a empresa.

O Trade Marketing também pode ser visto como uma ação comum entre a indústria e o distribuidor com o objetivo de otimizar o relacionamento e a sinergia dos canais para melhor servir ao consumidor. Dupuis; Tissier-Desbordes, (1996) propõe que o Trade 
Marketing deve ser um procedimento metódico, realizado em conjunto por fornecedores e varejistas, cujo objetivo é melhor atender às necessidades dos clientes e assim aumentar a rentabilidade e posição competitiva.

Para Randall (1994, p. viii), o varejo consolidou seu poder e, por isso, os fabricantes devem aumentar os esforços para construir e manter suas marcas fortes, mudando radicalmente suas estratégias e estrutura para se adaptar à realidade e construir parcerias com os varejistas. Este posicionamento é ecoado por Dawson e Shaw (1989), que reforça a necessidade da evolução na relação entre fornecedores e varejistas ao efetuar estudo com 42 grandes varejistas britânicos e 60 fornecedores.

Outra abordagem acerca do Trade Marketing é considera-lo como uma ferramenta de integração entre vendas e marketing. Em um estudo efetuado por Dewsnap e Jobber (2009) em empresa do Reino Unido, verificou-se como se dá a integração entre o departamento de vendas e marketing $\mathrm{O}$ trabalho concluiu que as ferramentas de colaboração entre estas áreas são o Trade Marketing e o gerenciamento de categorias.

O Trade Marketing também pode ter abordagem focada no relacionamento entre a indústria e o distribuidor, inclusive com a elaboração de planos de marketing em conjunto. Neste caso pode ser chamado de Partnering ou Partnership Marketing (DUPUIS; TISSIERDESBORDES, 1994, 1996). Mentzer, Min e Zacharia, (2000) abordam o Partnering como uma ferramenta para criar e manter a vantagem competitiva. Além disso, definem o Partnership como uma entidade interorganizacional construída entre duas organizações independentes, em uma relação vertical na cadeia de suprimentos. Este conceito é focado no relacionamento e na ação conjunta dos membros da cadeia.

Alguns autores tratam do tema e conceituam Trade Marketing como uma área que interage e entende os canais de distribuição. Neste caso, o Trade Marketing tem como objetivo maximizar o valor oferecido aos varejistas, garantir que as atividades efetuadas para desenvolver o negócio de cada cliente sejam feitas de forma rentável para a indústria e estabelecer formas em que o fornecedor tenha ou mantenha seu poder, dividindo e dominando os canais (MOTTA; SANTOS; SERRALVO, 2008, p. 43). Esta abordagem evidencia que o varejo deve ser visto não somente como um canal, mas também como um cliente, tratando-se assim, de uma variável incontrolável.

Para Alvarez, (2008, p. 73) o Trade Marketing pode ser entendido como "o planejamento e controle das ações de venda e de mercado e dos benefícios oferecidos ao consumidor final, por meio da verificação das relações de vendas estabelecidas com os 
varejistas". Esta definição é bastante focada em vendas e somente considera o varejista para as ações.

Os conceitos apresentados são complementares, de forma que é possível elencar os principais pontos levantados pelos autores em relação ao conceito de Trade Marketing. Assim, os conceitos apresentados podem ser categorizados em dois eixos principais: o relacionamento e a rentabilidade. No Quadro 3 são apresentados os eixos relacionamento e rentabilidade com os conceitos de Trade Marketing.

Quadro 3 - Resumo dos conceitos de Trade Marketing

\begin{tabular}{|l|l|}
\hline Eixos & Conceitos de Trade Marketing \\
\hline Relacionamento & Otimizar o relacionamento com o canal \\
\cline { 2 - 2 } & Construir parcerias entre fabricantes e varejistas \\
\hline Rentabilidade & Verificar o potencial do canal \\
\cline { 2 - 2 } & Elaborar programas de ação por canal \\
\cline { 2 - 2 } & Melhorar a rentabilidade por canal e por cliente \\
\hline
\end{tabular}

Fonte: Elaborado pela autora com base em Alvarez (2008, P. 73); Dupuis; Tissier-Desbordes, (1994, 1996); Motta; Santos e Serralvo (2008, p. 43); Randall (1994, P. Viii).

\subsubsection{Funções do Trade Marketing}

O principal objetivo do Trade Marketing é fornecer suporte às atividades das áreas de marketing e vendas, a fim de satisfazer as necessidades dos clientes intermediários e dos clientes finais (ALVAREZ, 2008, p. 71), e assim, aumentando o giro dos produtos no ponto de venda (PDV). Para Corstjens e Corstjens, (1995, p. 222) o Trade Marketing deve maximizar o valor oferecido aos varejistas, garantir a lucratividade das contas de clientes e minimizar os riscos da dependência da indústria em relação ao varejo. Para isso o departamento de Trade Marketing desenvolve suas atividades e tem diversas atribuições elencadas pela literatura.

Dentre as funções do Trade Marketing, uma delas pode ser relativa à segmentação dos canais de distribuição, com a análise de informações e definição de critérios para determinar os segmentos. O Trade Marketing pode ainda coletar, analisar e distribuir informações, construindo um Sistema de Informações próprio. Entender o comportamento dos shoppers pode contribuir para a realização de ações adequadas às necessidades dos consumidores. Quando as atividades de preço, produto e comunicação estão relacionadas aos canais de distribuição, o Trade Marketing ainda pode desempenhar funções relativas a estas atividades. Auxiliar o varejista com o gerenciamento de categorias também pode ser uma atribuição do 
Trade Marketing. Outra função que pode ser desempenhada pelo departamento de Trade Marketing é o desenvolvimento de relacionamento com os canais de distribuição. Além disso, o departamento deve ainda elaborar um plano de Trade Marketing e definir métricas para acompanhamento de resultados obtidos.

Assim, na sequência serão abordados os temas segmentação dos canais, sistema de informações de Trade Marketing, comportamento do shopper, produto, preço, comunicação gerenciamento de categorias, relacionamento com os canais de distribuição, plano de Trade Marketing e métricas de Trade Marketing. O objetivo é discutir as atividades que podem ser desempenhadas pelo Trade Marketing em cada uma destas categorias.

\subsubsection{Segmentação dos Canais de Distribuição}

A segmentação é a atividade de marketing capaz de identificar os diferentes grupos de consumidores e decidir sobre quais deles se deseja atuar (CAMPOMAR; IKEDA, 2006, p. 13). Isso possibilita que a empresa atenda de forma diferenciada aos variados grupos de clientes, oferecendo produtos adequados à necessidade de cada um deles.

No caso de empresas que decidam pela estrutura de canais com intermediários, a fim de atendê-los de forma diferenciada, estes canais podem ser alvo de segmentação. Alvarez, (2008, p. 104) aponta que os fornecedores podem aplicar aos seus canais o princípio de marketing one to one, ou seja, "clientes diferentes devem ter tratamento diferente".

Para Cônsoli e D'Andrea, (2010, p. 128) os fabricantes podem segmentar os varejistas utilizando critérios operacionais, táticos e estratégicos. A segmentação operacional pode ser por formato de varejo, número de check-outs ou pelo volume de compras. Esta segmentação pode proporcionar melhor eficiência logística e de atendimento. Já a segmentação que utiliza o critério tático é usada para determinar qual a frequência na qual os repositores devem estar em determinado ponto de venda e quais os investimentos mais adequados em merchandising e demais formas de comunicação. Para a segmentação tática podem ser utilizados os critérios: tipo de organização, como redes ou varejistas independentes, o posicionamento do varejista, como preço baixo, especializado, diferenciado, ou ainda, pode ser segmentado pelo públicoalvo que atende.

Por fim, a segmentação estratégica separa os clientes de acordo com a atratividade do cliente para o fornecedor. Esta atratividade pode ser determinada verificando informações sobre o momento presente do cliente, como contribuição em volume, taxa de crescimento do faturamento e rentabilidade sobre as vendas anuais e as projeções do cliente como potencial 
de crescimento, visibilidade e rentabilidade orçada. Outra possibilidade de segmentação apresentada por Cônsoli e D'Andrea, (2010, p. 129) é utilizando-se das avaliações do shopper em relação às lojas. Dessa forma, é possível aproximar-se dos interesses e expectativas dos clientes do varejista.

Alvarez, (2008, p. 104) discute a segmentação de acordo com a importância dos clientes no faturamento da empresa e da visibilidade. $\mathrm{O}$ autor ainda sugere que os principais clientes devem ser atendidos pelos Gerentes de Contas Especiais (Key Account Manager). Um ponto ressaltado é que a região em que o varejista está localizado deve ser levada em conta neste processo, pois um varejista pode ter mais força em determinada região do que uma grande rede nacional, mesmo que seu faturamento seja menor. O Quadro 4 resume os critérios que podem ser adotados para efetuar a segmentação dos canais de distribuição.

Quadro 4 - Critérios utilizados na segmentação dos canais

\begin{tabular}{|c|c|}
\hline Critérios utilizados para a Segmentação dos Canais & Autores \\
\hline $\begin{array}{ll}\text { - } & \text { Formato de varejo } \\
\text { - } & \text { Número de check-outs } \\
\text { - } & \text { Volume de compras } \\
\text { - } & \text { Organização do varejista } \\
\text { - } & \text { Posicionamento do varejista } \\
\text { - } & \text { Público-alvo do canal } \\
\text { - } & \text { Atratividade para o fornecedor }\end{array}$ & $\begin{array}{l}\text { (CÔNSOLI; D'ANDREA, } 2010 \text {, } \\
\text { p. 128) }\end{array}$ \\
\hline
\end{tabular}

Fonte: elaborado com base em Cônsoli e D'Andrea (2010, p. 128).

\subsubsection{Sistema de Informação de Trade Marketing}

No marketing o sistema de informação é composto por dados que são organizados e analisados com o objetivo de subsidiar as decisões relativas ao Marketing (CAMPOMAR; IKEDA, 2006, p. 35). Para Kotler e Keller (2006, P. 71) o sistema de informações de marketing é composto de pessoas, equipamentos e processos que têm como objetivo coletar, classificar, analisar e distribuir as informações para aqueles que tomam as decisões.

Para isso o sistema obtém dados a partir de inteligência, registros internos e pesquisa. A inteligência é formada por dados de eventos. Estes dados são ocasionais e não estruturados provenientes do ambiente externo à empresa. Os registros internos são dados referentes às atividades operacionais da empresa como relatórios de vendas e banco de dados de clientes. A pesquisa consiste na obtenção de informações para solução de um problema específico, 
utilizando estudos formais sobre oportunidades e ameaças. Nestes casos as empresas encomendam pesquisas para institutos.

As empresas devem manter um fluxo constante de informações para seus gerentes de marketing (KOTLER; KELLER, 2006, p. 71). Dessa forma, ao estabelecer um departamento de Trade Marketing, as empresas precisam desenvolver também um sistema de informação de Trade Marketing, o qual permitirá ao gerente de Trade Marketing se subsidar de informações para tomar decisões. Além disso, nos casos em que a decisão não compete ao departamento de Trade Marketing, estas informações podem alimentar o sistema de informação de outros departamentos, como marketing e vendas.

Para Alvarez, (2008, p. 117) este sistema deve conter e estar integrado com os dados de vendas e marketing, concorrentes, mercado, varejistas, microrregião e nichos específicos de canais. O Quadro 5 apresenta as ações que podem ser relacionadas ao Sistema de Informação de Trade Marketing.

Quadro 5 - Ações relacionadas ao Sistema de Informação de Trade Marketing

\begin{tabular}{|c|c|}
\hline Ações relacionadas ao Sistema de Informações de Trade Marketing & Autor \\
\hline $\begin{array}{l}\text { Coleta sistemática e contínua sobre: } \\
\text { - Marketing: posicionamento, estratégias de produto, estratégias de } \\
\text { comunicação, ações para o lançamento de novos produtos, } \\
\text { programação anual de comunicação, metas para o portfólio de } \\
\text { produtos. } \\
\text { - Vendas: Políticas comerciais, estrutura da equipe, atendimento a } \\
\text { clientes, cobertura do mercado, metas dos produtos e clientes } \\
\text { - Mercado: ações dos concorrentes, características dos canais e } \\
\text { clientes e competitividade em microrregiões } \\
\text { Clientes: ambiente competitivo do cliente, operação, } \\
\text { monitoramento do desempenho das ações desenvolvidas com o } \\
\text { cliente, acompanhamento de metas por clientes. }\end{array}$ & (ALVAREZ, 2008, p. 119) \\
\hline $\begin{array}{l}\text { - Inteligência: treinamento da equipe de vendas para que relate } \\
\text { acontecimentos; motivar os canais para passar informações } \\
\text { importantes, monitoramento de informações sobre ações de } \\
\text { concorrentes, comprar informações de fornecedores externos } \\
\text { - Registros internos: Relatórios de vendas, banco de dados de } \\
\text { clientes. } \\
\text { - Pesquisa: pesquisa de mercado, teste de preferência de produto, } \\
\text { previsão de vendas, avaliação de propaganda. }\end{array}$ & $\begin{array}{l}\text { (KOTLER; KELLER, 2006, p. } \\
\text { 73) }\end{array}$ \\
\hline
\end{tabular}

Fonte: elaborado com base em Alvarez (2008, p. 119); Kotler e Keller (2006, p. 73); Cônsoli e D'Andrea, (2010, p. 128). 


\subsubsection{Comportamento do Shopper}

A tradução da palavra shopper para o português segundo o dicionário Michaelis, (2009) é comprador. Como a palavra comprador é amplamente utilizada nas empresas para definir o indivíduo que efetua as compras para empresas no mercado business-to-business, diversos autores preferem utilizar o termo em inglês shopper para designar a pessoa que está efetuando a compra no varejo (ALVAREZ, 2008, p. 60; CHAMIE, 2012; CÔNSOLI; D'ANDREA, 2010, p. 127; UNDERHILL, 2009, p. 3). Por este motivo a autora do presente trabalho optou também por manter a palavra shopper sem tradução.

Shankar et al, (2011) define shopper como o indivíduo no "modo shopping". Levandose em consideração que a palavra shopping refere-se ao ato de efetuar compras (MICHAELIS, 2009), compreendendo a busca e a comparação de preço e marcas de produtos. Assim, pode-se concluir que o shopper é o indivíduo que está "fazendo shopping". Alvarez, (2008, p. 59) ainda esclarece que “o consumidor pode assumir diferentes papéis em seu processo de consumo e compra, os quais podem ou não ser exercidos pelo mesmo indivíduo", ou seja, o consumidor e o shopper podem não ser a mesma pessoa.

Como o shopper é o indivíduo que irá efetuar a compra e frequentar o ambiente de varejo, as ações de Trade Marketing devem ter foco neste personagem. Alguns autores exploraram uma área de estudo baseado no comportamento do shopper, o Shopper Marketing (CÔNSOLI; D'ANDREA, 2010, p. 146; SHANKAR et al., 2011). Para Shankar et al., (2011) o Shopper Marketing é o planejamento e execução de atividades que influenciam o shopper ao longo do processo de compra. Estas atividades são desenvolvidas baseando-se no entendimento do comportamento do shopper e tem como objetivo construir brand equity, ou seja, o valor da marca e engajamento de clientes.

O comportamento do shopper pode ser entendido como as atividades as quais as pessoas se ocupam quando obtêm produtos e serviços. Esta definição foi feita com base no conceito de comportamento do consumidor de Engel, Blackwell e Miniard (2011, p. 6) como sendo "atividades com que as pessoas se ocupam quando obtêm, consomem e dispõem de produtos e serviços". Para fornecer suporte as decisões, o Trade Marketing deve utilizar-se de pesquisas de canal e pesquisas de shoppers (CÔNSOLI; D'ANDREA, 2010, p. 125). As análises dos dados provenientes dessas pesquisas são chamadas shopper insights.

Cônsoli e D'Andrea (2010, p. 128) afirmam que o Trade marketing deve ter como atividade a segmentação de shopper dos canais de distribuição. O autor recomenda que as ações de Trade Marketing devem estar focadas no indivíduo que efetua a compra no varejo. 
Dessa forma, é possível otimizar as ações de merchandising e promoção de vendas, além de preço e mix de produtos. O Quadro 6 apresenta as ações que podem ser desenvolvidas por Trade Marketing em relação ao comportamento do shopper.

Quadro 6 - Ações relacionadas ao Comportamento do Shopper

\begin{tabular}{|c|c|}
\hline Ações relacionadas a Comportamento do shopper & Autor \\
\hline $\begin{array}{l}\text { - } \quad \text { Segmentar os shoppers dos canais de distribuição } \\
\text { - } \quad \text { Realizar pesquisas sobre comportamento do shopper }\end{array}$ & $\begin{array}{l}\text { (CÔNSOLI; D'ANDREA, 2010, } \\
\text { p. 129) }\end{array}$ \\
\hline
\end{tabular}

Fonte: elaborado com base em Cônsoli e D'Andrea, (2010, p. 129).

\subsubsection{Produto}

O Trade Marketing é capaz de observar o produto dentro do contexto do ponto de vendas, ou seja, ver a performance do produto no local onde os shoppers irão busca-los, visualiza-los e adquiri-los. Assim, é possível adaptar as estratégias relativas à produto aos canais de distribuição e ao shopper. As ações relativas à produtos que podem ser desenvolvidas pelo Trade Marketing, segundo Motta, Santos e Serralvo (2008, p. 53), devem levar em consideração três situações: a embalagem primária, a embalagem secundária e as oportunidades táticas.

Motta, Santos e Serralvo (2008, p. 54) consideram como embalagem primária aquela que é exposta ao consumidor no ponto de venda. Em relação a esta embalagem, deve-se oferecer variadas apresentações de um produto, com tamanho e formas variadas, para que seja possível que cada tipo de canal escolha a que mais lhe convém. Já a embalagem secundária é aquela utilizada para enviar o produto para o canal de distribuição. Neste ponto também a empresa deve ter diferentes quantidades de produto por embalagem secundária, a fim de adequar-se à necessidade do canal. Por último, aas oportunidades táticas, os autores sugerem que, para melhorar o relacionamento com os canais, produtores que estão com capacidade produtiva ociosa passem a fabricar marcas próprias de varejistas.

Para Alvarez, (2008, p. 90) a atuação de Trade Marketing em relação às atividades de produtos baseia-se em dar apoio e orientação às ações de marketing. Isto pode ocorrer no sentido de: avaliar os concorrentes, verificando ações, lançamento e variedade de produtos, participação do concorrente no mix do cliente e posicionamento; verificar o desempenho da linha de produtos da empresa, a presença dos itens, atratividade das embalagens, possibilidade de ampliação da linha e vendas por produto; fornecer orientações sobre novos produtos e extensões de linha; adequar o mix de produto de acordo com as necessidades e perfil do 
cliente; além de aplicar o posicionamento determinado pelo marketing no ponto de venda e garantir a visibilidade dos produtos.

O Quadro 7 apresenta as ações que podem ser desenvolvidas por Trade Marketing em relação ao produto.

Quadro 7 - Ações relacionadas ao Produto

\begin{tabular}{|c|c|}
\hline Ações relacionadas ao Produto & Autor \\
\hline $\begin{array}{ll}\text { - } & \text { Embalagem primária } \\
\text { - } & \text { Embalagem secundária } \\
\text { - } & \text { Oportunidades táticas }\end{array}$ & $\begin{array}{l}\text { (MOTTA; } \\
\text { SERRALVO, 2008, p. 53) }\end{array}$ \\
\hline 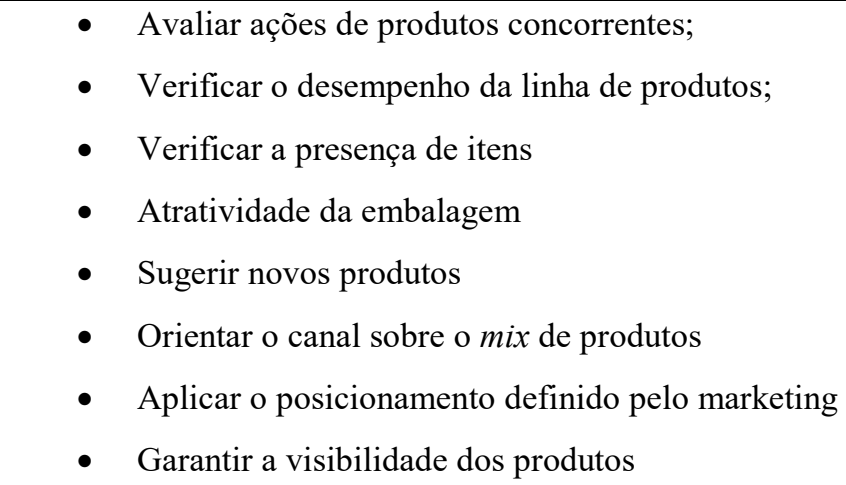 & (ALVAREZ, 2008, p. 90) \\
\hline
\end{tabular}

Fonte: elaborado com base em Alvarez (2008, p. 90); Motta, Santos e Serralvo (2008, p. 53)

\subsubsection{Preço}

É um desafio controlar os preços em empresas que contam com estrutura de canais de distribuição com diversos níveis: um produtor tem controle sobre a precificação do produto para o seu canal, mas o preço praticado pelo canal pode ser influenciado de acordo com o relacionamento estabelecido entre as partes.

Para Alvarez, (2008, p. 92) o departamento de Trade Marketing deve focar seus esforços no preço ao consumidor praticado pelo varejista. Os objetivos das ações de Trade Marketing relacionadas ao preço são garantir a margem de lucro da empresa, assim como de seus canais, e manter a atratividade do produto para o consumidor. Além disso, o Trade Marketing deve ter atenção para que o preço final não prejudique a imagem da marca e o posicionamento determinado pelo marketing.

As ações que o Trade Marketing pode desenvolver em relação a preços, com base em Alvarez, (2008, p. 92); Cônsoli e D'Andrea, (2010, p. 136) são: acompanhar os preços praticados e os de concorrentes, avaliar a elasticidade de preços, acompanhar as margens e giro de produtos, evitar o conflito entre os canais, orientar o varejista quando houver 
inadequações e participar da formação de preços. O Quadro 8 apresenta as ações que podem ser desenvolvidas por Trade Marketing em relação ao preço.

Quadro 8 - Ações relacionadas a Preço

\begin{tabular}{|l|l|}
\hline Ações relacionadas a Preço & Autor \\
\hline - Acompanhar os preços praticados pelo canal & (ALVAREZ, 2008, p. 92; \\
- Acompanhar os preços de produtos concorrentes praticados pelo & $\begin{array}{l}\text { CÔNSOLI; D'ANDREA, 2010, } \\
\text { p. 136) }\end{array}$ \\
- Avanal & \\
- Acompanhar margens e giro & \\
- Evitar conflito de canais & \\
- Orientar varejista quando houver inadequações & \\
\hline
\end{tabular}

Fonte: elaborado com base em Alvarez (2008, p. 92); Cônsoli e D’Andrea (2010, p. 136)

\subsubsection{Comunicação}

Dentre os elementos de comunicação apresentados no item 2.1, O Marketing, algumas formas de promoção estão mais focadas em interações entre os fabricantes e varejistas. Essas ferramentas são promoções de venda, merchandising, venda pessoal, ações cooperadas e eventos.

As promoções de vendas, merchandising e ação cooperada são atividades que favorecem a visualização dos produtos no ponto de venda. A venda pessoal é uma ferramenta utilizada tanto pelos fabricantes para efetuar a negociação com os canais de distribuição, quanto pelos varejistas para possibilitar a troca com os consumidores. Já os eventos favorecem a fortificação da marca perante os canais. Dessa forma, as atividades de Trade Marketing podem ser concentradas principalmente nestas atividades quanto a comunicação. Por este motivo serão abordados cada uma das ferramentas citadas.

Para Alvarez, (2008, p. 95) as atividades relativas à comunicação são as que têm mais visibilidade e que o Trade Marketing tem mais autonomia para decisão. $\mathrm{O}$ autor expõe ainda que estas atividades podem interferir no relacionamento com o varejista, nas vendas, em conflitos de canal, nas políticas de marketing e na imagem do produto. Portanto as ações não devem ser efetuadas aleatoriamente, mas sim de forma planejada. 
Os materiais de ponto de venda e comunicação com a equipe de vendas são um dos pontos ressaltados por Cônsoli e D'Andrea (2010, p. 162), no qual o Trade Marketing deve estar focado. Os materiais de comunicação como faixas de gôndolas e displays devem ser focados no shopper, segundo o autor. Além disso, também deve-se considerar a adequação dos materiais aos tipos de loja. Na comunicação com a equipe de vendas cabe ao Trade Marketing passar os objetivos das ações desenvolvidas para os vendedores da empresa.

Motta, Santos e Serralvo (2008, p. 64) afirmam que, quando surge a necessidade das empresas promoverem o produto no ponto de venda, os departamentos de marketing não estão preparados. Isto ocorre por dois motivos: o primeiro é que o marketing não possui equipe com conhecimentos sobre estas ações e, segundo, por ser uma atividade desvalorizada. O Quadro 9 apresenta as ações que podem ser desenvolvidas por Trade Marketing em relação ao comportamento do shopper.

Quadro 9 - Ações relacionadas à Comunicação

\begin{tabular}{|c|c|}
\hline Ações relacionadas à Comunicação & Autor \\
\hline - $\quad$ Promoção de vendas: degustação, concursos, sorteios & $\begin{array}{l}\text { (ALVAREZ, 2008, p. 144; } \\
\text { MOTTA; } \\
\text { SERRALVO, 2008, p. 62) }\end{array}$ \\
\hline - $\quad$ Merchandising & $\begin{array}{l}\text { (ALVAREZ, 2008, p. 144; } \\
\text { MOTTA; } \\
\text { SERRALVO, 2008, p. 62) }\end{array}$ \\
\hline - Materiais de ponto de venda & $\begin{array}{l}\text { (CÔNSOLI; D'ANDREA, } 2010 \text {, } \\
\text { p. 162) }\end{array}$ \\
\hline - Comunicação com a equipe de vendas & $\begin{array}{l}\text { (CÔNSOLI; D'ANDREA, 2010, } \\
\text { p. 162) }\end{array}$ \\
\hline - Ações cooperadas: tabloides, anúncios e ofertas de preço & $\begin{array}{l}\text { (MOTTA; } \\
\text { SERRALVO, 2008, p. 62; } \\
\text { ROSENBLOOM, 2008, p. 306; } \\
\text { ROSLOW; } \\
\text { NICHOLLS, 1993) }\end{array}$ \\
\hline - Vendas Diretas & (ROSENBLOOM, 2008, p. 314) \\
\hline - $\quad$ Eventos & $\begin{array}{l}\text { (FERRACCIÙ, 2007, p. 59; } \\
\text { ROSENBLOOM, 2008, p. 315) }\end{array}$ \\
\hline
\end{tabular}

Fonte: elaborado pela autora com base em Alvarez (2008, p. 144); Motta et al (2008, p. 62); Cônsoli e D'Andrea (2010, p. 162); Rosenbloom (2008, p. 306); Roslow, Laskey e Nicholls (1993); Ferracciù, (2007, p. 59). 


\subsection{Promoções de vendas}

As promoções de vendas são ferramentas utilizadas para incentivar, a curto prazo, a compra de produtos pelos consumidores ou canais de distribuição de forma mais rápida ou em maiores quantidades. Englobam amostras, cupons, reembolso, descontos, brindes, prêmios, recompensas, experimentação gratuita, garantias, promoções combinadas, promoções cruzadas, displays no ponto de venda e demonstrações (CRESCITELLI; SHIMP, 2012; FERRACCIÙ, 2007). No Quadro 10 estão relacionados os tipos de promoções de vendas e suas características.

Quadro 10 - Tipos de promoções de vendas e características.

Pacotes de produtos com desconto: oferecem ao consumidor desconto sobre o preço regular de um produto, estampados na etiqueta ou no pacote. Um pacote com preço reduzido é um pacote de um único produto vendido a um preço reduzido (como dois pelo preço de um). Um pacote conjugado são dois produtos relacionados vendidos juntos (como uma escova de dente e creme dental).

Brindes: mercadoria oferecida a um preço relativamente baixo ou grátis, como incentivo à compra de outro produto. O brinde pode acompanhar o produto dentro da embalagem ou ser anexado ao pacote. Pode também ser enviado pelo correio a consumidores, que enviam um comprovante de compra como a tampa da embalagem ou código de barras. Já o brinde self-liquidating é vendido abaixo do seu preço normal de varejo a consumidores que compram o produto.

Programa de fidelidade: programas que oferecem recompensas relacionadas à frequência e à intensidade na aquisição de bens ou serviços das empresas.

Garantias do produto: promessas explícitas ou implícitas de uma empresa de que seu produto terá o desempenho especificado ou de que, em caso de falha, ele será consertado ou terá seu valor reembolsado ao consumidor dentro de determinado prazo.

Promoções combinadas: duas ou mais marcas ou empresas se unem, oferecendo cupons de desconto ou reembolsos, e promovendo concursos para aumentar seu poder de atração.

Promoções cruzadas: utilização de uma marca para anunciar outra, não concorrente.

Prêmios (concursos, sorteios, jogos): os prêmios são oportunidades de ganhar dinheiro, viagens ou mercadorias como decorrência da compra de um produto. Um concurso conclama os consumidores a fazer uma inscrição, a ser examinado por um corpo de jurados que escolherá os melhores. Já nos sorteios, solicitase aos consumidores que inscrevam seu nome para premiação aleatória. Um jogo dá algo aos consumidores, que pode ajuda-los a ganhar um prêmio todas as vezes que efetuam uma compra.

Ofertas de reembolso em dinheiro pós-venda (rebate): proporcionam uma redução de preço depois da compra, e não na própria loja. O consumidor envia determinado comprovante de compra ao fabricante, que reembolsa parte do valor pago pelo correio.

Cupons: Cédulas que conferem ao portador o direito a um desconto declarado na compra de um produto específico; são enviados pelo correio, acompanham outros produtos ou são inseridas em anúncios de revistas ou jornais. 
Experimentação gratuita: compradores potenciais são incentivados a experimentar o produto sem nenhum ônus, na expectativa de que eles o comprem posteriormente.

Displays e demonstrações no PDV: exposição de displays e demonstrações de produtos, efetuadas no ponto de venda.

Amostras: oferta gratuita de determinada quantidade de produto entregue de porta em porta, enviado pelo correio, retirada em uma loja, anexada a outro produto ou exibida em uma oferta de propaganda.

Fonte: elaborado pela autora com base em Crescitelli e Shimp, (2012)

De acordo com Rosenbloom, (2008, p. 308) as promoções em loja são criadas para despertar o interesse dos consumidores pelos produtos. Para o Trade Marketing a chave das promoções desenvolvidas pelos fabricantes é constatar se os varejistas percebem o benefício destas ações.

\subsection{Merchandising}

No Brasil o termo merchandising é constantemente confundido com a ferramenta product placement. O termo product placement é designado para a inserção de uma mensagem paga sobre marca ou produto em filmes, novelas e programas (CRESCITELLI; CAMPOMAR; GIL, 2012, p. 572). Pela definição de product placement é possível perceber que esta ferramenta não tem nenhuma relação com atividades no ponto de venda. Utilizar o termo merchandising para designar esta ação é, para Ferracciù, (2007, p. 45), inaceitável.

$\mathrm{O}$ merchandising é uma atividade que ocorre somente no ponto de venda. Tem como objetivo a melhora da visibilidade de produtos e marcas a fim de motivar e influenciar as decisões de compra do shopper (BLESSA, 2008, p. 11). Já a American Marketing Association, (2015), explica que merchandising é "um termo de variados significados e não geralmente adotados. Pode referir-se às atividades promocionais dos fabricantes em loja ou à identificação das decisões de produtos e linha de produtos dos varejistas" (tradução nossa).

Para Ferracciù, (2007, p. 43) o merchandising é “o mais confuso, obscuro, enigmático e incompreensível termo do campo de marketing”. Isto porque há concepções errôneas sobre esta atividade. $\mathrm{O}$ autor alega que muitas vezes o merchandising é confundido com a confecção de materiais de ponto de venda como faixas, displays, móbiles. Os materiais de comunicação fazem parte do merchandising, com a elaboração de diversos tipos de peças como displays, móbiles, cartazes, stopper, faixas de gôndola, anúncios em rádio e TV internos na loja e outros (CRESCITELLI; SHIMP, 2012, p. 496). Entretanto esta ferramenta abriga não só o desenvolvimento destes materiais, mas também a exibitécnica, ou exposição de produtos nas prateleiras. A altura em que o produto se encontra na prateleira, assim como 
qual o produto que está ao lado, influencia a decisão de compra do shopper. Por este motivo há uma escolha cuidadosa do local em que cada produto deve permanecer na prateleira (BLESSA, 2008, p. 28).

Além disso, o merchandising preocupa-se também com a forma de comunicação de preço do produto, quantidade de produtos nas prateleiras, a posição da categoria no layout da loja. Tudo isso depende do fluxo de clientes no ponto de venda, como eles efetuam a movimentação nos corredores do varejista, quais áreas são mais visitadas e quais são as áreas menos visitadas na loja. Assim, pode-se dizer que o merchandising contempla a comunicação no ponto de venda, a exposição do produto nas gôndolas, a layoutização da loja, e também a distribuição das categorias nas gôndolas, levando-se em conta como o indivíduo que efetua a busca e a compra do produto no ponto de venda (o shopper) se movimenta.

O ponto de venda (PDV) é o local onde a venda é efetuada. Assim, a comunicação com o consumidor neste momento é fundamental. No PDV existe a oportunidade de impactar o shopper, que está receptivo a sugestão de produtos e marcas (CRESCITELLI; SHIMP, 2012, p. 495). Para os consumidores estas ações propiciam melhor informação sobre as marcas, relembra informações sobre produtos obtidas em outros meios. Para as empresas, esta ação é benéfica porque encoraja os consumidores a escolher marcas, em alguns casos por impulso. Este contexto torna o merchandising uma ferramenta de muito interesse para os fabricantes, pois melhora a visualização da marca pelo consumidor.

Sendo assim, os produtores iniciaram uma batalha pelas gôndolas do ponto de venda, a fim de melhorar a exposição de seus produtos e a comunicação da marca, pois notam que esta é "a última e melhor chance de fazer diferença" (CRESCITELLI; SHIMP, 2012, p. 495). Entretanto, os varejistas perceberam que as prateleiras são um recurso muito valioso e, assim, começaram a vender os espaços nas lojas para os fabricantes (CORSTJENS; CORSTJENS, 1995, p. 197).

\subsection{Venda pessoal}

Grande parte das empresas tem uma força de vendas responsável por identificar potenciais clientes e transforma-los em compradores (KOTLER; KELLER, 2006, p. 618). Estas equipes são de considerável representação e importância nas empresas, tanto é que há um departamento específico para esta atividade, que geralmente não está subordinado ao departamento de marketing. 
É interessante perceber que um fabricante tem sua força de vendas que atua junto aos canais de distribuição. Por outro lado, os canais de distribuição também têm suas próprias equipes de vendas. Neste caso, a força de vendas do atacadista é responsável por efetuar a venda para os varejistas, que por sua vez têm uma equipe que atende os consumidores. Assim, o produtor tem controle somente sobre as vendas da sua equipe. Entretanto, Alvarez (2004) comenta que, na visão tradicional dos mercados de massa, os gerentes de marca tinham como prioridade motivar os consumidores por meio de comunicação de massa. Consideravam o intermediário como um apoio para atingir o consumidor. $\mathrm{O}$ autor sugere que esta visão deve ser substituída pelo foco nos canais de distribuição.

Kotler e Keller (2006, p. 618) afirmam ainda que o vendedor é o elo entre a empresa e o cliente, podendo, inclusive, trazer informações sobre o cliente para a empresa. Para a organização da força de vendas, cabe à empresa determinar os objetivos da equipe de vendas, montar as estratégias da força de vendas, além de determinar a estrutura, tamanho e remuneração da equipe. O treinamento e supervisão dos vendedores faz parte da gestão da força de vendas. $\quad \mathrm{Na}$ organização da venda do produtor é necessário considerar a importância e a força do cliente no canal de distribuição. Além disso, é necessário passar o foco das vendas de curto prazo para a venda consultiva, priorizando o relacionamento como forma de desenvolver a negociação (ALVAREZ, 2004). Algumas empresas adotam em suas estruturas organizacionais a Gerência de Contas Especiais (Key Account Management), que visa o relacionamento de longo prazo e a interação com os clientes especiais.

\subsection{Ações cooperadas}

As ações cooperadas são campanhas realizadas em conjunto com os canais de distribuição, com o compartilhamento do custo da ação (CRESCITELLI; SHIMP, 2012, p. 8). Estas ações podem ter dois objetivos distintos. Para o fabricante o propósito é a formação da imagem da marca. Já para o varejista ou distribuidor é uma forma de estimular a compra (ROSLOW; LASKEY; NICHOLLS, 1993).

Rosenbloom (2008, p. 306) destaca que, para que a ação cooperada seja efeficaz, é preciso que o canal tenha estoque suficiente do produto, que o varejista coloque o display e que haja pessoal para fornecer suporte de venda ou promotores. Os fabricantes podem utilizar as revistas de atacadistas, que tem como foco o varejista, para comunicar sua marca e seus 
produtos. É comum que o varejista distribua tabloides, divulgando produtos com desconto e marcas. Os fabricantes também podem inserir suas marcas nestes materiais.

\subsection{Eventos}

Os eventos são feiras, exposições e congressos organizados anualmente por associações de setores específicos (ROSENBLOOM, 2008, p. 315) que propiciam o contato com os integrantes dos canais de distribuição. As empresas podem criar seus próprios eventos ou participar de eventos organizados por outrem.

Os principais objetivos da participação em eventos descritos por Ferracciù, (2007, p. 59) são: atrair novos distribuidores, apresentar produtos, conquistar a simpatia do canal de vendas, melhorar a relação com os clientes, interagir com todos os profissionais que atuam na empresa cliente, persuadir compradores de grandes ou pequenas organizações, motivar influenciadores e incentivar equipes de vendas.

A participação em eventos é justificada pelo envolvimento que ele produz. Ainda segundo Ferracciù, (2007, p. 60), nenhuma outra ferramenta de promoção proporciona tanto o envolvimento positivo do participante quanto os eventos. Além disso, os eventos podem fortalecer a imagem e o posicionamento da marca para o público.

Não foram encontradas na literatura de Trade Marketing referências sobre a organização de eventos como atribuição do departamento de Trade Marketing. Entretanto a literatura de canais de distribuição coloca que a organização de eventos para os canais de distribuição faz parte da gestão do canal (ROSENBLOOM, 2008, p. 315).

\subsubsection{Gerenciamento de Categorias}

O Gerenciamento de Categorias consiste em agrupar produtos em categorias, podendo ser por lógica de uso ou por marca, de acordo com a solução que estes produtos oferecem para o consumidor, além de acompanhar o desempenho de cada uma das categorias criadas. $\mathrm{O}$ objetivo desse modelo é facilitar o processo de compras, pois auxilia o consumidor em sua busca no ponto de venda. Além disso, melhora a gestão do varejista nas diversas linhas de produtos. $\mathrm{O}$ gerenciamento de categorias tem influência direta na exposição dos produtos no ponto de venda (ALVAREZ, 2008, p. 63).

O Trade Marketing pode auxiliar o varejista no processo de gerenciamento de categorias. As atividades que podem ser desenvolvidas são auxiliar o varejista a avaliar a 
categoria, sugerir variedade de produtos e marcas, preparar planogramas e acompanhar os resultados das categorias em conjunto com o varejista (ALVAREZ, 2008, p. 67). No Quadro 11 foram apresentadas as ações relativas ao gerenciamento de categorias, assim como a literatura sobre o tema.

Quadro 11 - Ações relacionadas ao Gerenciamento de Categorias.

\begin{tabular}{|c|c|}
\hline Ações relacionadas ao gerenciamento de categorias & Autor \\
\hline $\begin{array}{l}\text { - } \text { Auxiliar o varejista a avaliar a categoria } \\
\text { - } \quad \text { Sugerir variedade de produtos e marcas } \\
\text { - } \quad \text { Preparar planogramas } \\
\text { - Acompanhar os resultados das categorias em conjunto com o } \\
\text { varejista }\end{array}$ & (ALVAREZ, 1999, p. 67) \\
\hline
\end{tabular}

Fonte: elaborado com base em Alvarez (1999, p. 67).

\subsubsection{Relacionamento com os canais de distribuição}

O relacionamento colaborativo entre o produtor e o distribuidor é fundamental para que toda a cadeia tenha sucesso. Shankar et al. (2011) comenta que o foco deve ser estratégias do tipo ganha-ganha-ganha, em que, ao efetuar a troca, o produtor, varejista e o consumidor sejam beneficiados. Alvarez (2008, p. 36) destaca que as relações entre os produtores e seus canais podem ser informais ou formais. A diferença entre ambas é que nas relações formais existe um contrato entre as partes que determinará os direitos e deveres de cada membro.

Para o desenvolvimento do relacionamento, o Trade Marketing tem como responsabilidade planejar e executar ações relativas à programa de suporte, como treinamentos a equipe de vendas dos canais e participação no processo de remuneração do canal, considerando a equipe de vendas do canal como uma extensão da equipe de vendas do produtor. Além disso, o produtor ainda pode oferecer suporte para melhoria da operação do canal (CÔNSOLI; D'ANDREA, 2010, p. 117). Outras ações podem ser a utilização de programas de incentivo para sell out. Em ações mais colaborativas o produtor poderia compartilhar informações com os canais e ainda utilizar indicadores de desempenho em conjunto (CÔNSOLI; D'ANDREA, 2010, p. 119).

O objetivo dos programas de treinamento é a melhora do desempenho da equipe do canal. Para Rosenbloom, (2008, p. 312) esta ferramenta pode ser uma das mais eficazes para a comunicação com os membros do canal. $\mathrm{O}$ autor ressalta que para garantir a eficácia do treinamento, os produtores devem planejá-lo de forma a atender às necessidades específicas e 
ter boa aceitação por parte do varejista. Os programas de treinamentos podem ser desenvolvidos tanto para distribuidores quanto para varejistas e podem abordar temas como o conhecimento dos produtos e técnicas de vendas.

As diversas ferramentas que podem ser desenvolvidas para estimular o relacionamento com os canais de distribuição estão descritas no Quadro 12.

Quadro 12 - Ações para desenvolvimento do Relacionamento com os Canais de Distribuição

\begin{tabular}{|c|c|}
\hline Ações para desenvolvimento do Relacionamento com os Canais & Autor \\
\hline $\begin{array}{l}\text { - } \quad \text { Participação no processo de remuneração; } \\
\text { - } \quad \text { Programa de suporte para melhorias nas operações do canal; } \\
\text { - } \quad \text { Programas de incentivos para a equipe do canal; } \\
\text { - } \quad \text { Compartilhamento de informações; } \\
\text { - } \quad \text { Utilização de indicadores de desempenho em conjunto; }\end{array}$ & $\begin{array}{l}\text { (CÔNSOLI; D'ANDREA, 2010, p. } \\
117)\end{array}$ \\
\hline - Treinamentos para a equipe de vendas do canal & $\begin{array}{l}\text { (CÔNSOLI; D'ANDREA, 2010, p. } \\
\text { 117; ROSENBLOOM, 2008, p. 312) }\end{array}$ \\
\hline
\end{tabular}

Fonte: elaborado pela autora com base em Cônsoli e D'Andrea (2010, p. 117); Rosenbloom (2008, p. 312).

\subsubsection{Plano de Trade Marketing}

Alvarez, (2008, p. 123) sugere a elaboração de um plano de Trade Marketing para as contas chave ou segmentos de clientes. O desenvolvimento de um plano do fabricante em conjunto com o varejista é colocado por Shankar et al. (2011) como uma inovação na relação entre os fabricantes e varejistas. O Trade Marketing deve identificar os clientes que são mais importantes para a empresa e desenvolver um plano contendo metas de desenvolvimento e participação no cliente em termos de mix de produtos, ocupação de espaços, vendas e rentabilidade (ALVAREZ, 2008, p. 123).

\subsubsection{Métricas de Trade Marketing}

Ao realizar ações relativas a Trade marketing, as empresas necessitam utilizar indicadores para verificar a efetividade das ações desenvolvidas (ALVAREZ, 2008, p. 133; CÔNSOLI; D'ANDREA, 2010, p. 145; MOTTA; SANTOS; SERRALVO, 2008, p. 83). Outra possibilidade é que, ao realizar estas aferições, o gerente tenha conhecimento sobre as 
ações que mais geram e que não geram retorno sobre o investimento (CÔNSOLI; D'ANDREA, 2010, p. 231).

Motta, Santos e Serralvo (2008, p. 84) sugerem a utilização dos seguintes indicadores: resultados de vendas, comparando os resultados obtidos com aqueles que foram projetados; participação de mercado, verificando o quanto de mercado foi possível ganhar dos concorrentes; rentabilidade, medindo o retorno obtido nos canais de distribuição; a distribuição, avaliando a efetividade da distribuição; e execução no ponto de venda, ou seja, verificar como o produto está presente no ponto de venda. Para isso deve-se mensurar o espaço e a localização da exposição e a satisfação do varejista, determinando o grau de satisfação com as ações.

Algumas ações são mais complexas para determinação de métricas, principalmente quando o objetivo é subjetivo, como posicionamento da marca por exemplo. Dessa forma, Alvarez, (2008, p. 137) sugere o uso de métricas quantitativas e qualitativas. Como métricas quantitativas, o autor sugere o acompanhamento de selling in (venda para o canal), selling out (venda do canal para o consumidor), margens de contribuição, vendas do produto em relação a sua categoria, ampliação do espaço de vendas e ampliação do mix de produtos. Já as métricas qualitativas apresentadas pelo autor são o índice de lembrança da marca, quantidade de consumidores alcançados, quantidade vendida durante a ação, custo por cliente acessado e por índice de lembrança. Alvarez (2008, p. 138 ) ainda apresenta métricas para a determinação do custo das ações.

Para Cônsoli e D’Andrea (2010, p. 234), as métricas de Trade Marketing podem ser financeiras e operacionais. As métricas financeiras apresentadas pelos autores são: o retorno sobre o investimento (ROI), relacionando o incremento de receita gerado pela ação à contribuição e investimento destinado; grau de alavancagem em Trade Marketing (GATM), composto pela razão entre a variação de venda e variação de despesas; e alavancagem operacional (GAO), calculada pela razão da variação do lucro operacional e variação das vendas.

Nas métricas operacionais foram determinados pilares que são sortimento, preço praticado na ponta, visibilidade e promoção. Para cada um destes pilares devem ser estipulados níveis de execução ideal. Uma auditoria é efetuada nas lojas e comparada a estes níveis estabelecido.

O Quadro 13 sintetiza as métricas sugeridas pelos autores. 
Quadro 13 - Métricas utilizadas em Trade Marketing

\begin{tabular}{|c|c|}
\hline Métricas utilizadas em Trade Marketing & Autor \\
\hline $\begin{array}{ll}\text { - } & \text { Resultados de vendas } \\
\text { - } & \text { Participação de mercado } \\
\text { - } & \text { Rentabilidade } \\
\text { - } & \text { Distribuição } \\
\text { - } & \text { Execução no ponto de venda } \\
\text { - } & \text { Satisfação do varejista }\end{array}$ & (MOTTA; SANTOS; SERRALVO, 2008, p. 83) \\
\hline $\begin{array}{l}\text { Métricas quantitativas } \\
\text { - Selling out e Selling in } \\
\text { - Margens de contribuição } \\
\text { - Vendas do produto em relação a categoria } \\
\text { - Ampliação do espaço de vendas } \\
\text { - Ampliação da linha de produtos } \\
\text { Métricas qualitativas } \\
\text { - Índice de lembrança da marca } \\
\text { - Quantidade de consumidores alcançados } \\
\text { - Quantidade vendida durante a ação } \\
\text { - Custo por cliente acessado e por índice de }\end{array}$ & (ALVAREZ, 2008, p. 136) \\
\hline $\begin{array}{l}\text { Métricas Financeiras } \\
\text { - Return on Investment (ROI) } \\
\text { - Grau de alavancagem em Trade Marketing } \\
\text { (GATM) } \\
\text { - Alavancagem Operacional (GAO) } \\
\text { Métricas operacionais } \\
\text { - Sortimento } \\
\text { - Preços praticados na ponta } \\
\text { - Visibilidade } \\
\text { - Promoção }\end{array}$ & (CÔNSOLI; D’ANDREA, 2010, p. 234) \\
\hline
\end{tabular}

Fonte: elaborado com base em Cônsoli e D'Andrea, (2010, p. 234).

Por meio da revisão bibliográfica foram categorizados os seguintes temas para as atribuições do Trade Marketing: estrutura de Trade Marketing, segmentação de canais de distribuição, sistema de informação de Trade Marketing, comportamento do shopper, produto, preço, comunicação, gerenciamento de categorias, relacionamento com os canais de distribuição, plano de Trade Marketing e Métricas de Trade Marketing. Estas categorias foram utilizadas para a elaboração do roteiro de entrevistas e para a análise da pesquisa de campo. Os temas estão apresentados na Figura 12, atribuições do Trade Marketing. 


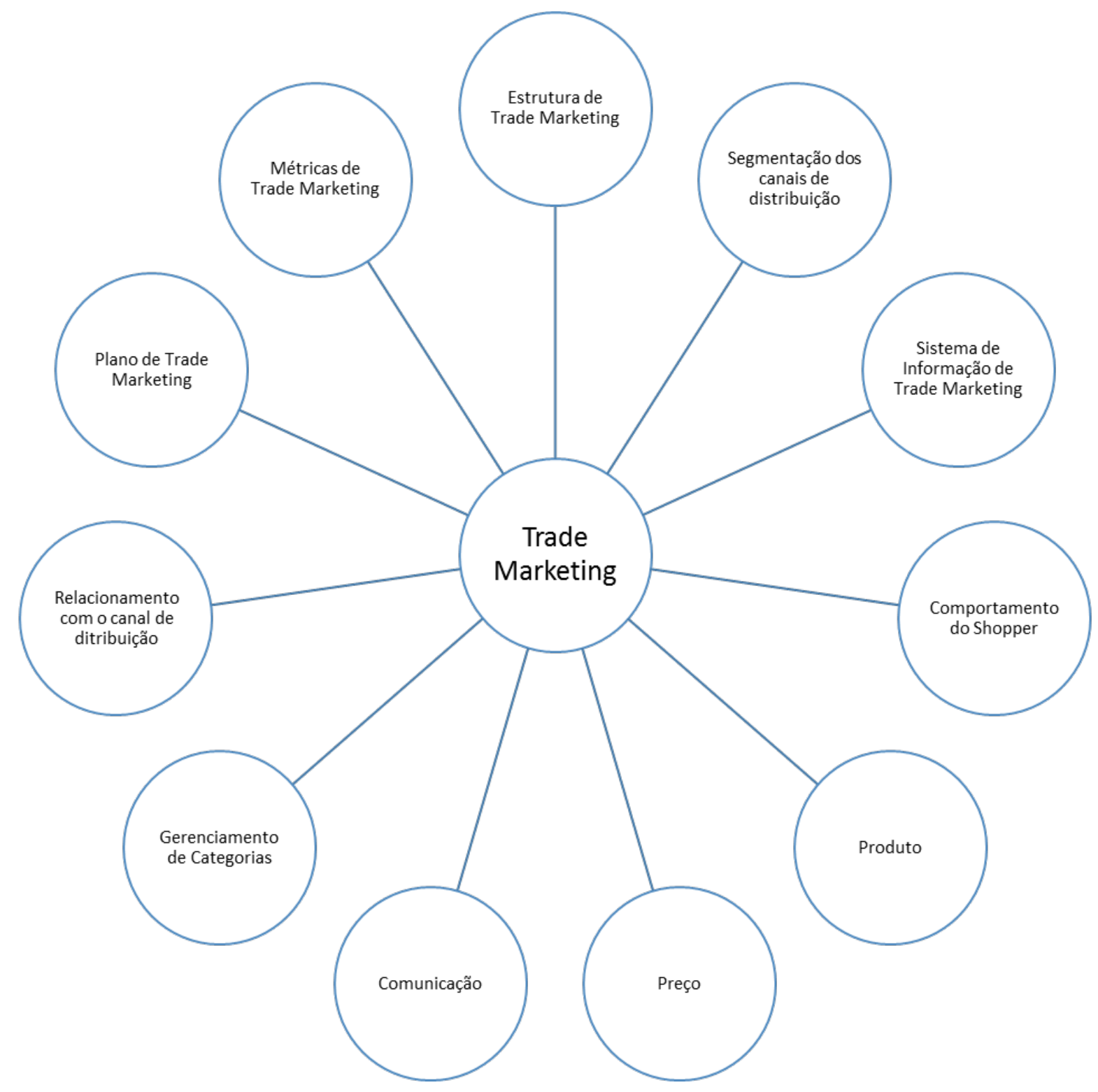

Fonte: elaborada pela autora

\subsection{O setor farmacêutico}

Como proposto, o presente trabalho tem como objetivo investigar as atividades de Trade Marketing no setor farmacêutico. Dessa forma, é essencial o conhecimento sobre o setor, contemplando sua importância na economia e especificidades que o tornam peculiar.

O setor farmacêutico abrange os fabricantes, comércios atacadistas e varejistas de produtos farmacêuticos. Trata-se de um setor altamente regulamentado, uma vez que o 
produto principal é o medicamento. O setor ainda conta com diversas particularidades que afetam as decisões de marketing e de Trade Marketing.

O mercado mundial de medicamentos movimentou, em 2013 a quantia de US\$ 980 trilhões e há projeções que em 2016 movimente cerca de US\$ 1.200 trilhões. O Brasil representa o sexto colocado no mercado mundial, sendo que em 2016 pode passar para a quarta colocação (INTERFARMA, 2014). O total de vendas no preço de fábrica, sem desconto e com impostos do ano de 2003 a 2015 está representado no Gráfico 1

Gráfico 1 - Total de vendas no mercado farmacêutico brasileiro

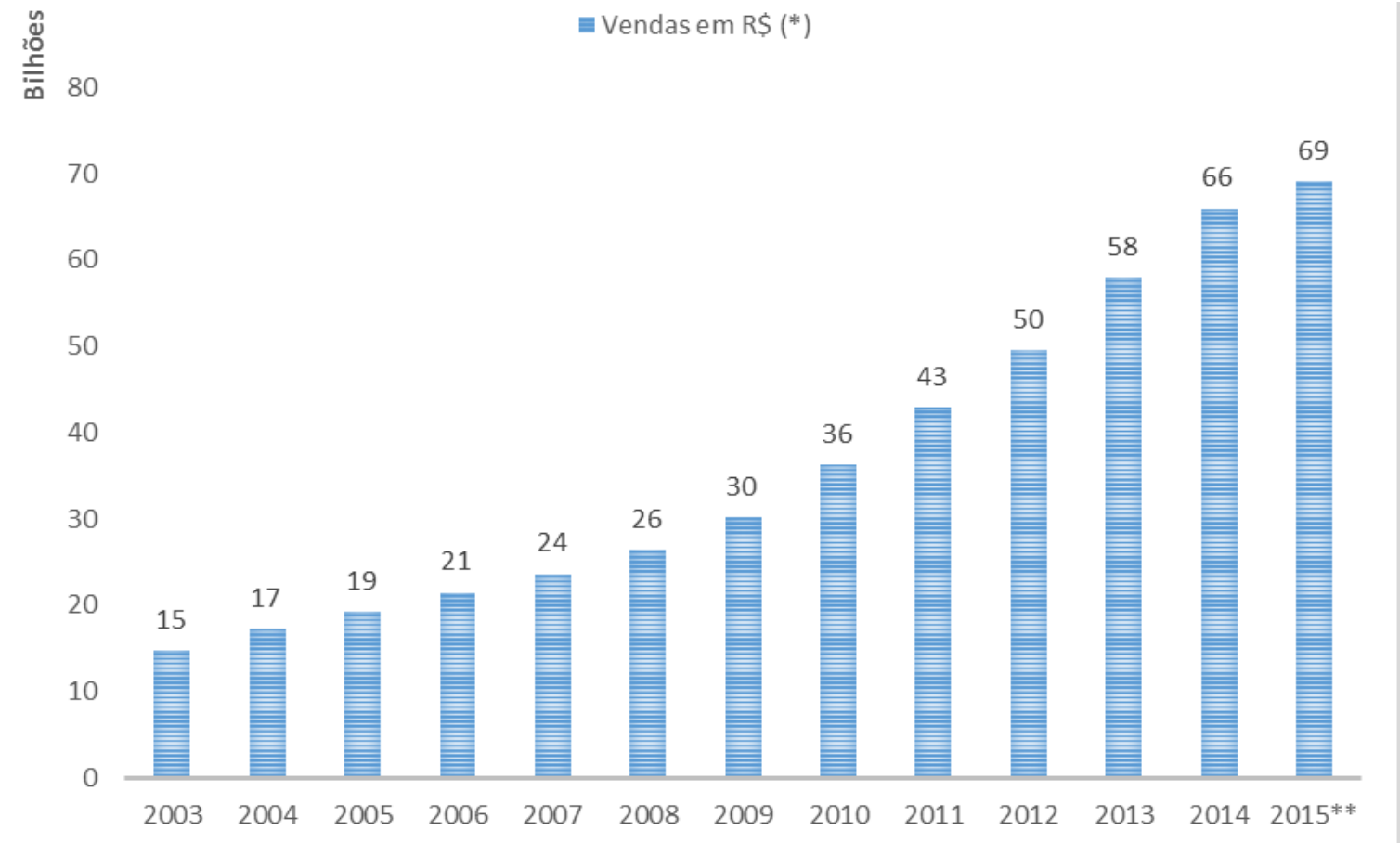

* Preço fábrica, sem desconto e com impostos. ** Projeção de vendas. Fonte: Sindusfarma (2015)

O Gráfico 2 apresenta o total de unidades vendidas de medicamentos no ano de 2003 à 2015 (SINDUSFARMA, 2015). 
Gráfico 2 - Total de unidades vendidas no mercado farmacêutico brasileiro

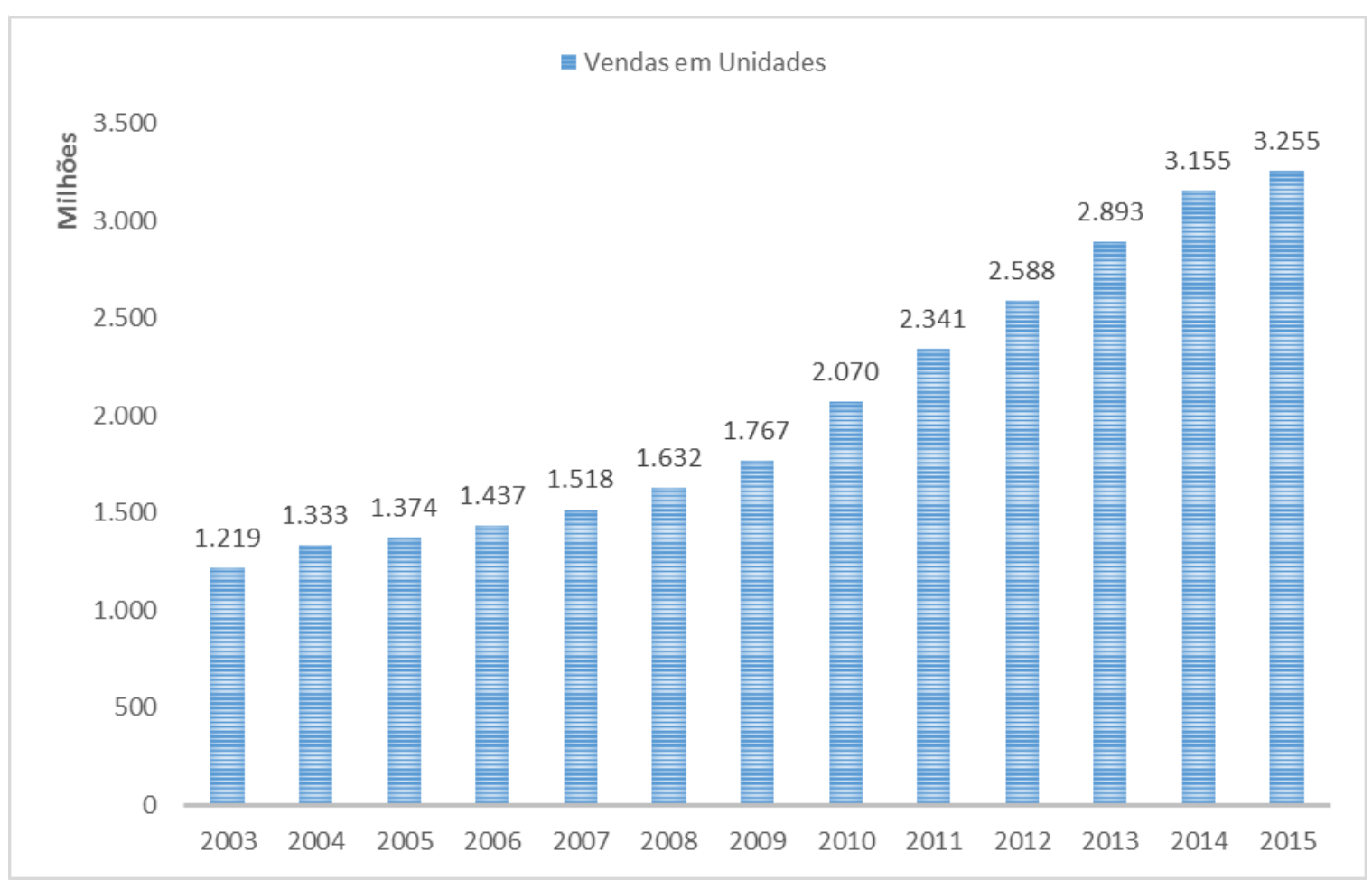

Fonte: Sindusfarma (2015)

O mercado de produtos genéricos está representado no Gráfico 3. Os dados são referentes ao volume de vendas de medicamentos genéricos de 2003 a 2015 no preço fábrica, sem desconto e com impostos, em milhões de reais. 
Gráfico 3 - Volume de vendas de medicamentos genéricos no período de 2003 a 2015, no preço fábrica, sem desconto e com impostos

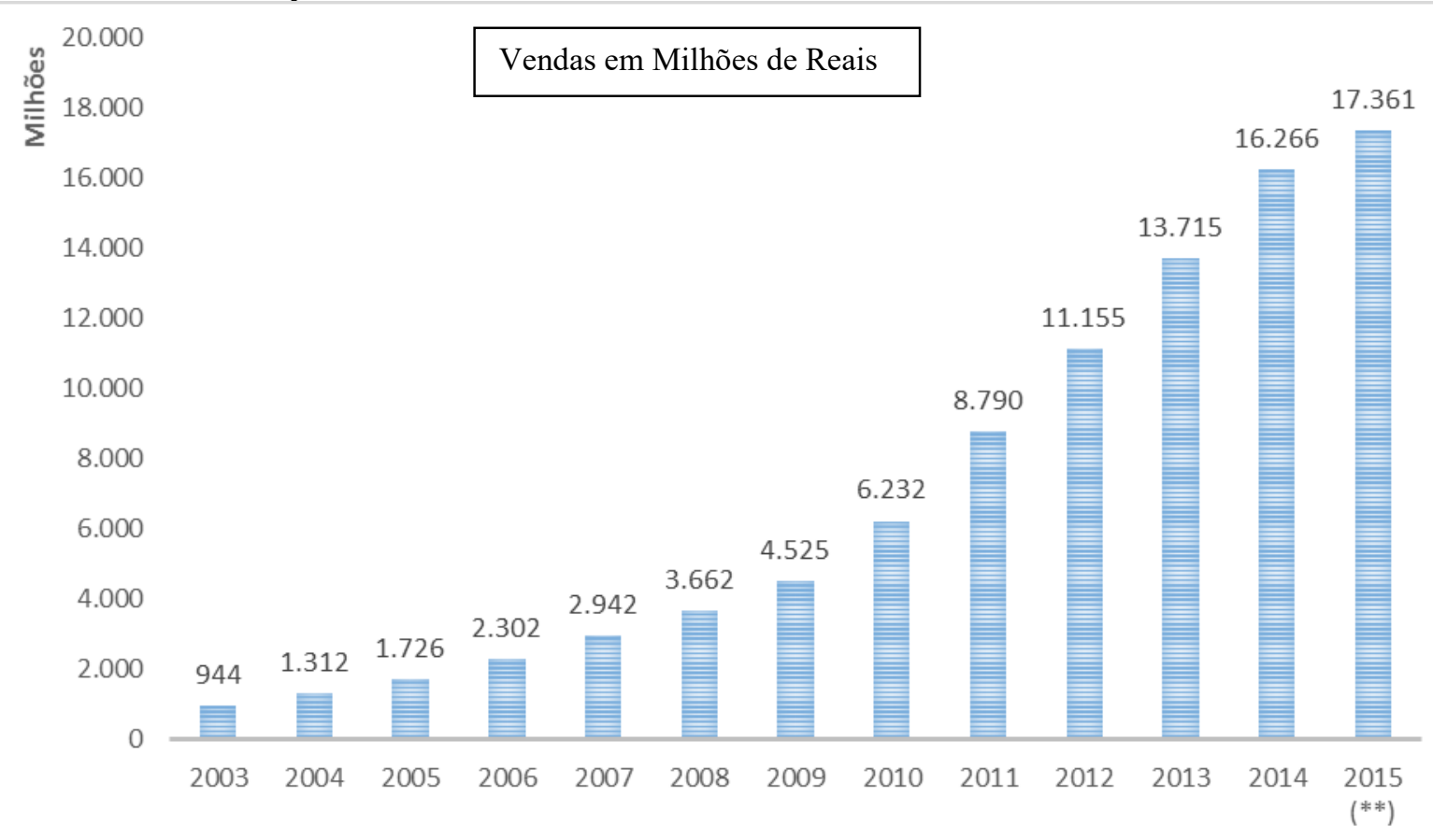

** projeção para o ano de 2015.

Fonte: Sindusfarma (2015)

Nota-se pela análise dos Gráficos 1, 2 e 3 que o mercado farmacêutico vem crescendo ao longo dos anos. Em relação às indústrias farmacêuticas existentes no Brasil, a maior delas é o Laboratório Ache, seguido por EMS Pharma, Sanofi, Eurofarma e Medley. No Quadro 14 estão relacionadas, em ordem crescente, as maiores empresas fabricantes de produtos farmacêuticos do Brasil em 2013, assim como seu volume de vendas em milhões de reais e a participação no mercado.

Quadro 14 - Ranking dos maiores laboratórios farmacêuticos do Brasil em 2013.

\begin{tabular}{|l|l|l|l|}
\hline Rk & Laboratório & Vendas (milhões de R \$) & Participação (\%) \\
\hline 1 & Ache & 2.215 & $5,85 \%$ \\
\hline 2 & EMS & 2.169 & $5,73 \%$ \\
\hline 3 & Sanofi & 2.069 & $5,47 \%$ \\
\hline 4 & Eurofarma & 1.698 & $4,49 \%$ \\
\hline 5 & Medley & 1.130 & $2,99 \%$ \\
\hline 6 & Novartis & 1.094 & $2,89 \%$ \\
\hline 7 & Neo Química & 1.031 & $2,72 \%$ \\
\hline 8 & Pfizer & 1.027 & $2,71 \%$ \\
\hline 9 & Bayer Pharma & 983 & $2,60 \%$ \\
\hline 10 & Biolab & 892 & $2,36 \%$ \\
\hline
\end{tabular}




\begin{tabular}{|l|l|l|l|}
\hline 11 & Takeda & 877 & $2,32 \%$ \\
\hline 12 & MSD & 857 & $2,27 \%$ \\
\hline 13 & Boehringer Ing & 830 & $2,19 \%$ \\
\hline 14 & Merck Serono & 811 & $2,14 \%$ \\
\hline 15 & Libbs & 760 & $2,01 \%$ \\
\hline 16 & Astra Zeneca & 694 & $1,83 \%$ \\
\hline 17 & Mantecorp & 651 & $1,72 \%$ \\
\hline 18 & DM & 627 & $1,66 \%$ \\
\hline 19 & Glaxosmithkline (GSK) & 617 & $1,63 \%$ \\
\hline 20 & Abbott & 517 & $1,51 \%$ \\
\hline
\end{tabular}

Fonte: Interfarma (2014).

Os produtos farmacêuticos mais vendidos no país estão relacionados no Quadro 15, que apresenta a posição no ranking, o medicamento, se a venda é sob prescrição ou se o medicamento é isento de prescrição, o fabricante do produto e a venda em milhões de reais no ano de 2013.

Quadro 15 - Ranking de produtos farmacêuticos mais vendidos no Brasil no ano de 2013.

\begin{tabular}{|l|l|l|l|l|r|}
\hline RK & Medicamento & Prescrição & Indicação & Fabricante & $\begin{array}{l}\text { Vendas } \\
\text { milhões de R\$ }\end{array}$ \\
\hline 1 & Dorflex & Isento & Dor & Sanofi & 358,9 \\
\hline 2 & Neosaldina & Isento & Dor & Takeda & 205,8 \\
\hline 3 & Cialis & Prescrição & Disfunção Erétil & Lilly & 154,6 \\
\hline 4 & Cicatricure & Isento & Cicatrização & Genomma Lab & 148,3 \\
\hline 5 & Victoza & Prescrição & Diabetes & Novo Nordisk & 145,4 \\
\hline 6 & Selozok & Prescrição & Hipertensão Arterial & Astra Zeneca & 142,7 \\
\hline 7 & Puran T4 & Prescrição & Hipotireoidismo & Sanofi & 142,6 \\
\hline 8 & Aradois & Prescrição & Hipertensão Arterial & Biolab & 142,2 \\
\hline 9 & Torsilax & Prescrição & Miorrelaxante & Neo Quiímica & 141,4 \\
\hline 10 & Cerazette & Prescrição & Contraceptivo & MSD & 133,5 \\
\hline 11 & Glifage XR & Prescrição & Diabetes & Merck Serono & 129,8 \\
\hline 12 & Yaz & Prescrição & Contraceptivo & Bayer Pharma & 127,1 \\
\hline 13 & Sal de Eno & Isento & Antiácido & GSK & 121,9 \\
\hline 14 & Buscopam & Isento & Dor & Boehringer Ing & 119,7 \\
\hline 15 & Composto & & & & 118,4 \\
\hline 16 & Pantus & Prescrição & Diabetes & Sanofi & 117,2 \\
\hline 17 & Lexapro & Prescrição & Depressão & Lundbeck & 114,0 \\
\hline 18 & Crestor & Prescrição & Hipercolesterolemia & Astra Zeneca & 113,8 \\
\hline 19 & Galvus MET & Prescrição & Diabetes & Novartis & 112,9 \\
\hline 20 & Hipoglós NF & Isento & Assaduras & Procter & 111,9 \\
\hline Fon & adaptado pela & & & \\
\hline
\end{tabular}

Fonte: adaptado pela autora de Interfarma, (2014)

Analisando-se os Quadros 14 e 15 é possível notar que o mercado de produtos farmacêuticos é bem pulverizado, pois a participação das empresas no mercado é próxima. Outro ponto é que nem sempre os maiores laboratórios fabricam os medicamentos mais 
vendidos. Entretanto, o ranking do Quadro 15 de produtos mais vendidos contempla apenas produtos com marca, não estando inseridos os medicamentos genéricos, ou seja, aqueles que não possuem um nome de marca.

\subsubsection{Contexto histórico dos medicamentos no Brasil}

Na história dos medicamentos, destacam-se dois momentos principais: o primeiro a segunda guerra mundial e segundo a descoberta dos antibióticos. As indústrias farmacêuticas surgiram no século XVIII. No final da década de 1930 foram descobertos os antibióticos. Este fato aliado à segunda guerra mundial configurou a necessidade de produção em massa de medicamentos. Assim, a indústria farmacêutica mundial se fortificou, tendo um crescimento vertiginoso.

No Brasil, até a década de 1940 não havia a presença de um número considerável de indústrias farmacêuticas no país. Os medicamentos consumidos eram vindos dos Estados Unidos e Europa ou eram produzidos nos laboratórios das farmácias. A partir dos anos 40 algumas indústrias se instalaram no Brasil e as farmácias puderam se tornar revendedoras, indústrias nacionais ou farmácias de manipulação.

No ano de 1971, o Brasil decide não reconhecer as patentes de medicamentos, o que deu origem aos medicamentos chamados similares. Estes eram cópias feitas pelos laboratórios nacionais de medicamentos patenteados em outros países. Em 1976 autorizou-se o registro de medicamentos similares junto à Vigilância Sanitária. Os medicamentos similares continham os mesmos ativos que os medicamentos inovadores, ou seja, os medicamentos que efetuaram a pesquisa e desenvolvimento do fármaco e iniciaram sua comercialização. Os fabricantes de medicamentos similares não precisavam apresentar testes que comprovassem a equivalência ao medicamento de referência (CREMESP, 2013). Não apresentar os testes de equivalência significa que não havia necessidade de comprovar que o medicamento similar era exatamente igual ao medicamento referência. Porém estes medicamentos ainda deveriam apresentar testes de eficácia.

Nos anos anteriores a 1983 os medicamentos tinham em sua embalagem apenas seu nome fantasia. A partir do ano mencionado, foi estipulado que os fabricantes inserissem, além do nome fantasia, o nome do ativo do medicamento, ou seja, o nome genérico, padronizado pela Denominação Comum Brasileira (DCB). A Lei de Patentes é promulgada em 1996 e estabelece que o prazo para que a patente dos medicamentos expire seja de 20 anos a partir da 
data da patente. Após este período podem ser fabricados medicamentos similares (CREMESP, 2013).

Para aumentar o acesso da população a medicamentos, uma das estratégias utilizadas pelo governo foi a implementação da política de medicamentos genéricos no ano de 1999 (DIAS; ROMANO-LIEBER, 2006). A política de medicamentos genéricos estabelecida pela Lei 9.787 de 1999 define o medicamento genérico, estabelece a política de genéricos e dispõe sobre a utilização de nomes genéricos em produtos farmacêuticos.

A criação da Agência Nacional de Vigilância Sanitária (Anvisa) ocorre em 26 de janeiro de 1999. Este órgão é uma autarquia que tem como área de atuação todos os setores que de alguma forma estão relacionados a produtos e serviços que possam afetar a saúde da população brasileira (ANVISA, 2015). Dessa forma, todo o setor farmacêutico passa a ser regulamentado por esta agência.

Em 2003, a Resolução RDC n 134/2003, estabeleceu que, na renovação de registro dos medicamentos similares, os fabricantes são obrigados a apresentar o nome do medicamento de referência a que se pretende comprovar equivalência, assim como os testes de equivalência farmacêutica (BRASIL, 2003). No ano de 2014 a Agência Nacional de Vigilância Sanitária regulamenta a intercambialidade entre os medicamentos referência e os similares equivalentes, ou seja, a possibilidade de troca entre estes medicamentos.

\subsubsection{O marketing farmacêutico}

Este item tem como objetivo discutir as peculiaridades do marketing no setor farmacêutico. Para isso, o tópico irá abordar as atividades de marketing para produtos farmacêuticos, separadamente, passando pelo produto, preço, praça e promoção.

\subsubsection{Produto}

O produto de mais foco das empresas farmacêuticas são os medicamentos. A definição de medicamento é a seguinte: "produto farmacêutico, tecnicamente obtido ou elaborado, com finalidade profilática, curativa, paliativa ou para fins de diagnósticos" (BRASIL, 1973). Portanto, pela definição dada, os medicamentos englobam vacinas, contrastes utilizados para fins diagnósticos e produtos com fins curativos, como antibióticos, ou para melhora de sintomas, como analgésicos e antitérmicos. 
Apesar do medicamento ser o bem principal produzido e comercializado pelo setor farmacêutico, há ainda outras categorias de produtos que são passíveis de produção e comercialização pelas indústrias. São eles os cosméticos, dermocosméticos, suplementos alimentares e nutricosméticos. Para registro de produtos junto a ANVISA, há apenas três classes de produtos: os medicamentos, os cosméticos e os alimentos. Entretanto algumas marcas são posicionadas como intermediários entre estas classes e recebem nomenclaturas no mercado diferentes das categorias que são efetivamente registrados.

Os dermocosméticos são produtos registrados como cosméticos. Entretanto seu posicionamento de marketing tem uma abordagem que faz com que o produto pareça um intermediário entre os cosméticos e os medicamentos. Os nutricosméticos são produtos registrados como um alimento ou suplemento alimentar, mas seus apelos são focados em melhoras estéticas. Por esse motivo, podem ser considerados um intermediário entre os alimentos e os cosméticos. Grande parte dos alimentos não são produtos regulamentados pela ANVISA, mas sim pelo Ministério da Agricultura. Entretanto alguns tipos de alimentos são objetos de regulamentação pela ANVISA, principalmente aqueles que alegam ter propriedades funcionais e para saúde, como por exemplo os suplementos alimentares e vitamínicos. Nesse caso, estes produtos podem ser considerados nutracêuticos.

$\mathrm{Na}$ figura 13 estão representados de forma esquemáticas as diferentes categorias de produtos que podem ser produzidos e comercializados no setor farmacêutico (KROHN; KLEBER; SCHAFFAR, 2008).

Figura 13 - Categorias produzidas e comercializadas no setor farmacêutico.

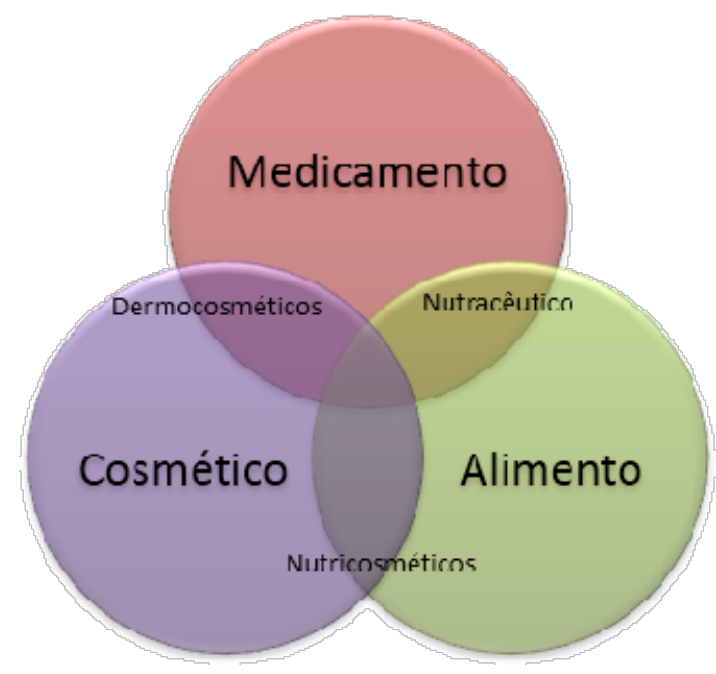

Fonte: Krohn, Kleber e Schaffar (2008) 
Os medicamentos podem ser classificados em: isentos de prescrição, venda sob prescrição e venda sob prescrição com retenção de receita, além dos medicamentos de uso restrito hospitalar. Como o próprio nome já diz, os medicamentos classificados como uso restrito hospitalar somente podem ser utilizados e comercializados para hospitais.

Os medicamentos isentos de prescrição (MIP) também são conhecidos como medicamentos OTC. Esta sigla vem do termo inglês over-the-counter, que significa "depois do balcão". Ou seja, são aqueles medicamentos que podem ficar no autosserviço, pois como são utilizados para transtornos de menor gravidade não há necessidade de prescrição médica.

Para pertencer a categoria de MIP, o fármaco deve constar nos grupos terapêuticos e indicações terapêuticas, determinados pela ANVISA e descritos na Lista de Grupos e Indicações Terapêuticas Especificadas (GITE). Além disso, não devem ser administrados por via parenteral, ou seja, não podem ser injetáveis. No Brasil, no ano de 2009, houve uma tentativa da ANVISA de transferir estes produtos para fora do autosserviço. Entretanto este artigo da legislação acabou sendo revogado e os MIP puderam retornar para a área original de vendas das farmácias.

Diversos estudos na área de marketing utilizam o mercado farmacêutico, em especial o OTC para desenvolvimento de trabalho de campo. Vormittag, (2000) verificou o comportamento de compra de medicamentos isentos de prescrição. Já Mazzero, (2014) discute as métricas para o accountability em marketing em indústrias farmacêuticas que tem em seu portfólio medicamentos OTC.

Os medicamentos que não pertencem a lista GITE são, portanto, medicamentos sob prescrição médica. Podem ser chamados também de medicamentos Rx. Esta sigla vem do termo latim "recipe" que significa "faça uso de" (PALUDETTI, 2015). Estes possuem em suas embalagens uma tarja vermelha com os dizeres "venda sob prescrição médica". Dentro desta categoria há ainda aqueles com tarja vermelha ou preta e que a receita fica retida na farmácia. Estes medicamentos são produtos entorpecentes, psicotrópicos e os antimicrobianos.

Outra forma de classificar o medicamento no Brasil é a seguinte: inovação, referências, genéricos, similares e similares equivalentes. O medicamento inovação é o primeiro a ser lançado e geralmente é o detentor da patente. Na Figura 14 é apresentado o processo de criação e desenvolvimento de um medicamento. Segundo a Interfarma, (2012) cerca de 10.000 moléculas são pesquisadas para cada medicamento viável. Quando a pesquisa aponta moléculas com potencial para se tornar um medicamento, estas são patenteadas e inicia-se a fase de pesquisa e desenvolvimento do medicamento com os testes 
pré-clínicos e testes clínicos, que duram em torno de 10 anos. Quando o medicamento é aprovado para a comercialização, este é considerado um medicamento inovação. Assim que esta patente termina, ocorre à entrada da comercialização do medicamento genérico e similares.

Figura 14- Tempo para desenvolvimento de um medicamento

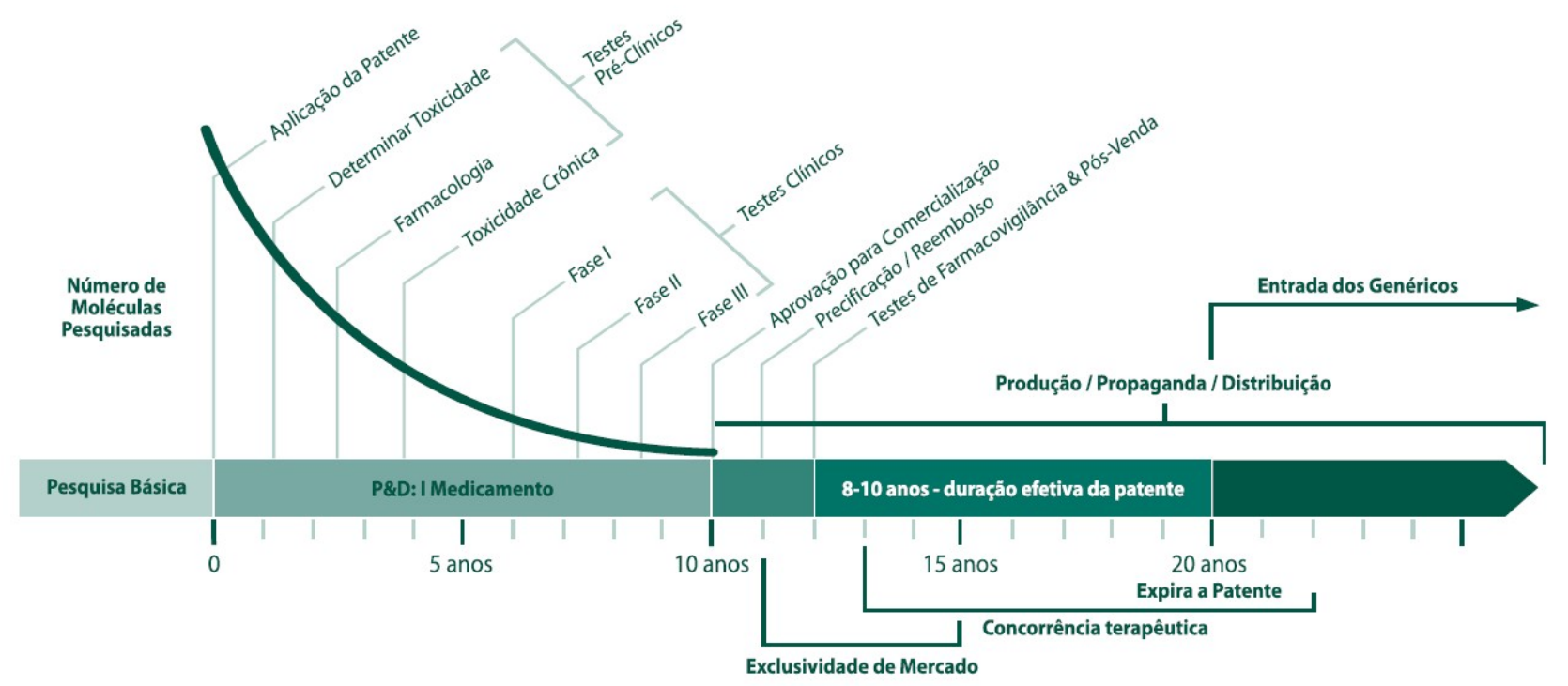

Fonte: Interfarma (2014)

Para que o medicamento genérico seja fabricado quando a patente do medicamento inovador expira, a ANVISA indica o medicamento inovador como sendo o medicamento de referência. O medicamento de referência é definido como: "produto inovador registrado no órgão federal responsável pela vigilância sanitária e comercializado no País, cuja eficácia, segurança e qualidade foram comprovadas cientificamente junto ao órgão federal competente, por ocasião do registro" (BRASIL, 1999).

Existe também a possibilidade de, após expirada a patente, serem lançados os medicamentos similares que são definidos como:

“aquele que contém o mesmo ou os mesmos princípios ativos, apresenta a mesma concentração, forma farmacêutica, via de administração, posologia e indicação terapêutica, preventiva ou diagnóstica, do medicamento de referência registrado no órgão federal responsável pela vigilância sanitária, podendo diferir somente em características relativas ao tamanho e forma do produto, prazo de validade, embalagem, rotulagem, excipientes e veículos, devendo sempre ser identificado por nome comercial ou marca;" (BRASIL, 1999). 
Já o medicamento Genérico é conceituado pela legislação brasileira como sendo: "Medicamento similar a um produto de referência ou inovador, que se pretende ser com este intercambiável, geralmente produzido após a expiração ou renúncia da proteção patentearia ou de outros direitos de exclusividade, comprovada a sua eficácia, segurança e qualidade e designado pela DCB ou, na sua ausência, pela DCI" (BRASIL, 1999).

Ou seja, é um medicamento que contém em sua fórmula os mesmos princípios ativos, na mesma concentração, forma farmacêutica, via de administração, posologia e indicação terapêutica do medicamento de referência que se pretende copiar. Além disso, o medicamento genérico necessita comprovar que tem os mesmos efeitos de eficácia e segurança que o medicamento de referência. A grande diferença do medicamento genérico em relação aos demais é que o seu nome será designado pela Denominação Comum Brasileira (DCB) ou Denominação Comum Internacional (DCI). Esta nomenclatura será estipulada de acordo com o nome do fármaco ou princípio farmacologicamente ativo constante na lista da ANVISA (BRASIL, 1999).

Segundo Dias e Romano-Lieber (2006) os medicamentos genéricos são mais baratos que seus referencias devido a seu fabricante não ter investimentos para pesquisa e desenvolvimento do fármaco e também não ter despesas com a promoção da marca. Estudo realizado por Vieira e Zucchi (2006) avaliou a diferença de preço dos medicamentos genéricos e seus referências, de janeiro de 2000 à junho de 2004. Constatou que, ao longo destes anos pesquisados, o medicamento genérico foi se tornando mais barato do que o seu medicamento de referência. Ainda que na introdução dos medicamentos genéricos, estes eram, em média, $40 \%$ mais baratos que seus referências.

Esse dado corrobora com a obrigação legal que o medicamento genérico deve ser no mínimo 30\% mais barato do que o medicamento de referência. Em pesquisa realizada pelo Procon, (2013) sobre a variação de preços do medicamento genérico em relação ao medicamento de referência, foi verificado que, em média, os medicamentos genéricos são $54,68 \%$ mais baratos do que os de referência. Quando a comparação foi entre medicamentos genéricos em diferentes estabelecimentos foram encontradas variações de até 1.129,21\%.

Conforme colocado por Yamaguti et al. (2008), as indústrias farmacêuticas fabricantes de medicamentos genéricos iniciaram um processo de divulgação das marcas, neste caso do próprio laboratório produtor, para diferenciar seus medicamentos. Cabe ressaltar que o médico pode colocar na prescrição que não é favorável à troca do medicamento referência 
pelo genérico. Entretanto, ao prescrever um medicamento genérico o médico não pode determinar a marca.

Por fim, o medicamento similar equivalente é o medicamento similar intercambiável que tenha apresentado os estudos de bioequivalência farmacêutica e biodisponibilidade ao órgão regulatório (BRASIL, 2014). Neste caso, o medicamento similar equivalente pode ser trocado com o medicamento referência. A Figura 15 apresenta um esquema que demonstra, em resumo, as possíveis trocas entre os medicamentos referência, similar equivalente e genérico.

Figura 15 - Intercambialidade de medicamentos.

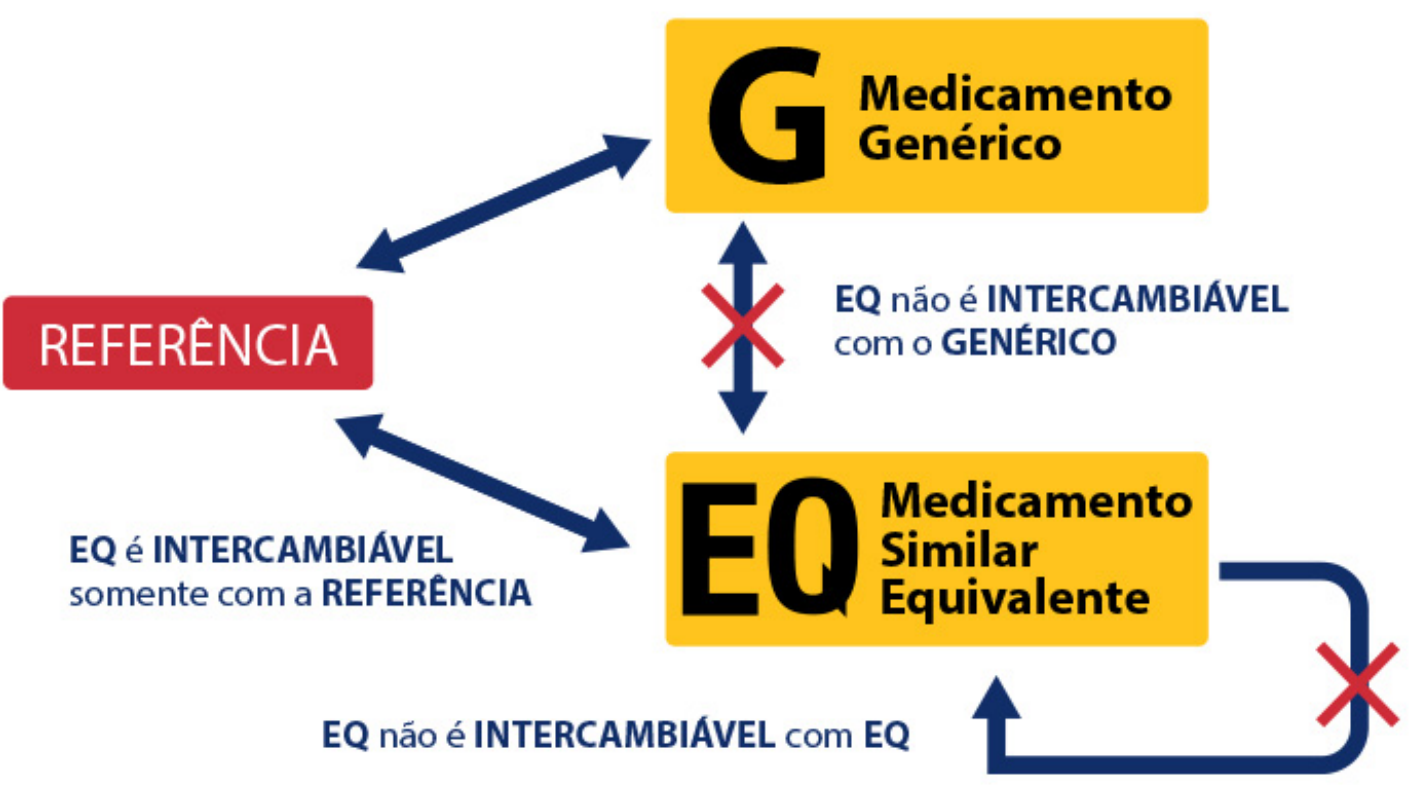

Fonte: EMS Marcas (2015).

A troca de medicamentos pode ser efetuada entre o referência e o similar equivalente; e o referência e o genérico. Todavia, a troca entre similar equivalente e genérico não é possível de acordo com a legislação vigente. A troca entre medicamentos equivalentes também não é permitida.

\subsubsection{Preço}

A Anvisa determina o preço de novos medicamentos e anualmente efetua o ajuste de preços dos medicamentos por meio da Secretaria Executiva da Câmara de Regulação do 
Mercado de Medicamentos (CMED). O objetivo da CMED é a regulação do mercado. Assim, no momento em que uma empresa solicita o registro de um medicamento ou a revalidação do registro, a CMED reúne informações econômicas sobre o produto e determina o preço de fábrica (PF) e o preço máximo ao consumidor (PMC) (BRASIL, 2003).

$\mathrm{O}$ PF é o preço máximo que o produto pode ser vendido pelo fabricante ao distribuidor. Já o PMC é o preço máximo que a droga pode ser vendida aos consumidores. Dessa forma, a decisão das empresas sobre preço refere-se a política de descontos que será praticada para o canal e, no caso do varejista, para os consumidores, não podendo ultrapassar o limite determinado pelo órgão regulador.

\subsubsection{Praça}

No setor farmacêutico há apenas um canal de marketing possível, pois é determinado pela legislação. Os medicamentos somente podem ser produzidos por indústrias farmacêuticas e somente podem ser vendidos para distribuidores farmacêuticos e varejos farmacêuticos.

O varejo farmacêutico comercializa medicamentos e outros produtos para saúde e cuidados pessoais para o consumidor final, contemplando farmácias e drogarias (RIBEIRO; ZILBER; PRIETO, 2009). Em 1973, a Lei 5.991 definiu farmácia como

"Estabelecimento de manipulação de fórmulas magistrais e oficinais, de comércio de drogas, medicamentos, insumos farmacêuticos e correlatos, compreendendo o de dispensação e o de atendimento privativo de unidade hospitalar ou de qualquer outra equivalente de assistência médica"

e drogaria como: "estabelecimento de dispensação e comércio de drogas, medicamentos, insumos farmacêuticos e correlatos em suas embalagens originais"(BRASIL, 1973). Na prática, a diferença entre farmácia e drogaria é que os produtos comercializados pela drogaria devem ser fabricados em uma indústria e ser comercializados em sua embalagem original. Já a farmácia pode efetuar a produção e manipulação de medicamentos e outros produtos para saúde.

Segundo Parente (2011, p. 25), o varejo pode ser classificado de acordo com o tipo de propriedade. Para Ribeiro et al. (2009) a classificação segundo os tipos existentes de propriedade no varejo farmacêutico, sendo elas:

- Redes: empresas que possuem diversas lojas operando sob a mesma direção. Parente (2011, p. 25) ainda destaca que as vantagens competitivas das redes aumentam conforme o número de lojas, pois o poder de barganha junto aos fornecedores é maior. 
Além disso, há economia de escala para diversas atividades relacionadas à empresa, como propaganda, tecnologia, logística e obtenção de informações de marketing. Por outro lado, as diferentes unidades possuem mercados distintos o que pode representar um desafio.

- Estabelecimentos independentes: possui apenas uma loja. São caracterizadas por serem pequenos e terem baixo nível de investimento em tecnologia. Por possuírem apenas uma unidade, a gestão do negócio é mais simples e permite que aja mais integração entre as diversas atividades da empresa e a necessidade de seus consumidores, assim como mais velocidade de resposta a alterações do ambiente externo. Em contrapartida, as farmácias e drogarias independentes tem pouco poder de barganha com seus fornecedores por efetuar um baixo volume de compras (PARENTE, 2011, p. 25).

- Franquias: sistema em que o franqueador oferece a licença de comercialização de um bem, serviço, método de trabalho e marca a empresas afiliadas, ou seja, o franqueado efetua o pagamento de uma taxa mensal ou royalties sobre as vendas.

- Associativismo: é caracterizado pela associação de várias farmácias ou drogarias independentes, que podem operar com a mesma marca e compartilhar atividades, com o objetivo de aumentar a força competitiva, como o poder de barganha com fornecedores.

A estrutura de canais mais utilizada pelas indústrias farmacêuticas é aquela que utiliza os atacadistas como intermediários para distribuição de produtos para as pequenas redes e farmácias independentes e para as grandes redes. A venda pode ser direta da indústria. O setor farmacêutico muitas vezes utiliza seus vendedores para negociação com as pequenas farmácias e o distribuidor faz a operação logística (OPL).

Assim como na indústria farmacêutica, o atacado e varejo de medicamentos também são extremamente regulados. A legislação brasileira determina que, além de medicamentos, as farmácias e drogarias também podem vender produtos correlatos, como cosméticos, perfumes, produtos de higiene pessoal, produtos médicos e para diagnóstico in vitro. Estes produtos, entretanto. devem estar regularizados junto a ANVISA (Agência Nacional de Vigilância Sanitária). Outros produtos que também podem ser comercializados são: mamadeiras, chupetas, bicos e protetores de mamilos, lixas de unha, alicates, cortadores de unhas, palitos de unha, afastadores de cutícula, pentes, escovas, toucas para banho, lâminas para barbear e barbeadores, além de alguns tipos de alimentos, suplementos vitamínicos, chás e mel (BRASIL, 2009b). 
Estes produtos podem ser segmentados em departamentos ou categorias para que o varejista possa acompanhar o desempenho e o gerenciamento de cada uma delas. Além disso, a definição de categorias auxilia na decisão da localização de cada produto dentro da loja. Para isso deve ser analisada a lógica do consumidor e como ele efetua suas decisões de compra (Parente, 2011, p. 314).

\subsubsection{Promoção}

Poucos setores têm a sua promoção tão regulada quanto o setor farmacêutico. A promoção é uma atividade que visa atrair cliente para a loja e motivar as compras. Entretanto, para o medicamento há uma grande preocupação com o uso racional do produto. Assim, as normas em relação à comunicação se justificam para evitar a automedicação irresponsável.

Um estudo desenvolvido por Huertas, (2005) sobre a promoção de medicamentos, verificou a atitude do consumidor frente aos apelos racionais ou emocionais da propaganda. A atual regulamentação não permite a promoção indireta de medicamentos. No artigo $4^{\mathrm{o}}$ a resolução dispõe que:

"Fica vedado utilizar técnicas de comunicação que permitam a veiculação de imagem e/ou menção de qualquer substância ativa ou marca de medicamentos, de forma não declaradamente publicitária, de maneira direta ou indireta, em espaços editoriais na televisão; contexto cênico de telenovelas; espetáculos teatrais; filmes; mensagens ou programas radiofônicos; entre outros tipos de mídia eletrônica ou impressa."

Assim, elementos de comunicação como a publicidade, patrocínio, product placement e advertainment não podem ser efetuados. A legislação também não permite diversas ferramentas de promoção de vendas como a distribuição de brindes, sorteios e programa de fidelidade. As demais ações podem ser efetuadas para o consumidor final somente quando se tratar de produtos para OTC ou para profissionais prescritores e dispensadores para medicamentos com ou sem prescrição. O Quadro 16 relaciona os elementos de comunicação e as restrições legais para a promoção de medicamentos.

Quadro 16 - Elemento de comunicação e restrições legais para medicamentos

\begin{tabular}{|l|l|}
\hline $\begin{array}{c}\text { Elementos da } \\
\text { Comunicação }\end{array}$ & \multicolumn{1}{c|}{ Restrições legais para promoção de medicamentos } \\
\hline Propaganda & $\begin{array}{l}\text { Permitido para o consumidor final somente de produtos OTC, desde que sejam } \\
\text { seguidas as disposições da RDC 96/2008 }\end{array}$ \\
\hline Publicidade & Proibido, Artigo $4^{\circ}$ da RDC 96/2008 \\
\hline Relações Públicas & Permitido \\
\hline Patrocínio & Proibido, Artigo $4^{\circ}$ da RDC 96/2008 \\
\hline
\end{tabular}




\begin{tabular}{|c|c|}
\hline Promoção de vendas: & \\
\hline Brindes & Proibido pelo Artigo $5^{\circ}$ da RDC 96/2008 \\
\hline Sorteio & Proibido pelo Artigo $10^{\circ}$ da RDC 96/2008 \\
\hline Amostras & $\begin{array}{l}\text { Proibido para medicamento OTC } \\
\text { Permitido amostras de medicamentos sob prescrição para os prescritores, } \\
\text { conforme Artigo } 33^{\circ} \text { da RDC } 96 / 2008\end{array}$ \\
\hline Descontos & Permitido \\
\hline Marketing direto & $\begin{array}{l}\text { Permitido para o consumidor final somente de produtos OTC, desde que sejam } \\
\text { seguidas as disposições da RDC } 96 / 2008\end{array}$ \\
\hline Venda Pessoal & Permitido \\
\hline Product Placement & Proibido, Artigo $4^{\circ}$ da RDC 96/2008 \\
\hline Ações cooperadas & $\begin{array}{l}\text { Permitido para o consumidor final somente de produtos OTC, desde que sejam } \\
\text { seguidas as disposições da RDC } 96 / 2008\end{array}$ \\
\hline Marketing digital & $\begin{array}{l}\text { Permitido para o consumidor final somente de produtos OTC, desde que sejam } \\
\text { seguidas as disposições da RDC } 96 / 2008\end{array}$ \\
\hline Eventos Científicos & Permitido \\
\hline Merchandising & Permitido, produtos OTC devem atentar a RDC 41/2012 \\
\hline Folhetos/Catálogos & Permitido, desde que sejam seguidas as disposições da RDC 96/2008 \\
\hline $\begin{array}{l}\text { Marketing de } \\
\text { Relacionamento }\end{array}$ & $\begin{array}{l}\text { Permitido, entretanto os programas de fidelidade não podem ter o medicamento } \\
\text { como alvo de pontuações conforme RDC } 96 / 2008\end{array}$ \\
\hline Mídia Exterior & $\begin{array}{l}\text { Permitido para o consumidor final somente de produtos OTC, desde que sejam } \\
\text { seguidas as disposições da RDC } 96 / 2008\end{array}$ \\
\hline Advertainment & Proibido pelo Artigo $4^{\circ}$ da RDC 96/2008 \\
\hline Marketing viral & $\begin{array}{l}\text { Permitido para o consumidor final somente de produtos OTC, desde que sejam } \\
\text { seguidas as disposições da RDC } 96 / 2008\end{array}$ \\
\hline
\end{tabular}

Fonte: elaborado pela autora

Neste cenário, as ações permitidas são amplamente exploradas pelas indústrias farmacêuticas. A mais frequente delas é a visitação médica. Um jargão foi criado na indústria para sinalizar os medicamentos cuja principal ação é a visitação médica: são chamados de "medicamentos éticos". Entretanto, o termo é inadequado, pois incita a compreensão de que as empresas que não investem em propaganda médica têm medicamentos "não-éticos" ou "antiéticos".

As demais ações permitidas são para o profissional dispensador, ou seja, o farmacêutico. Uma observação importante é que as restrições da legislação em relação à comunicação referem-se à marca do medicamento e não a marca da indústria farmacêutica.

Após a revisão teórica realizada por meio do levantamento bibliográfico, não foi possível responder ao problema de pesquisa proposto. Dado a relevância do assunto em questão e a escassez de pesquisas acadêmicas na área de Trade Marketing, principalmente com o enfoque no setor farmacêutico, surge a necessidade de efetuar uma pesquisa de campo. Sendo assim, o próximo capítulo irá apresentar a abordagem metodológica utilizada. 


\section{PROCEDIMENTOS METODOLÓGICOS DA PESQUISA DE CAMPO}

O presente trabalho tem como objetivo verificar como ocorre o processo de desenvolvimento das atividades de Trade Marketing especificamente no setor farmacêutico. Sendo assim, foi realizado o levantamento bibliográfico sobre o tema proposto. A revisão teórica possibilitou levantar atividades que são desempenhadas pelo Trade Marketing em outros setores. Entretanto, a literatura não respondeu ao problema de pesquisa.

Portanto, a pesquisa de campo foi conduzida para atender ao objetivo determinado. No presente capítulo são abordados o método escolhido, assim como a justificativa para escolha e os procedimentos adotados para a condução da pesquisa de campo.

\subsection{Abordagem e classificação da metodologia da pesquisa de campo}

A pesquisa científica pode ser classificada de diversas formas. Quando classificada quanto ao objetivo a pesquisa pode ser exploratória, descritiva-conclusiva ou causal conclusiva. Se classificada quanto ao processo, pode ser qualitativa ou quantitativa. Já a classificação pela lógica, pode ser indutiva ou dedutiva. Pela forma de coleta, pode ser por levantamento, observação ou experimento. E quanto ao resultado, a pesquisa pode ter caráter de ciência ou de tecnologia (CAMPOMAR, 2013). No Quadro 17 estão descritas as formas de classificação da pesquisa científica.

Quadro 17 - Formas de classificação da pesquisa científica

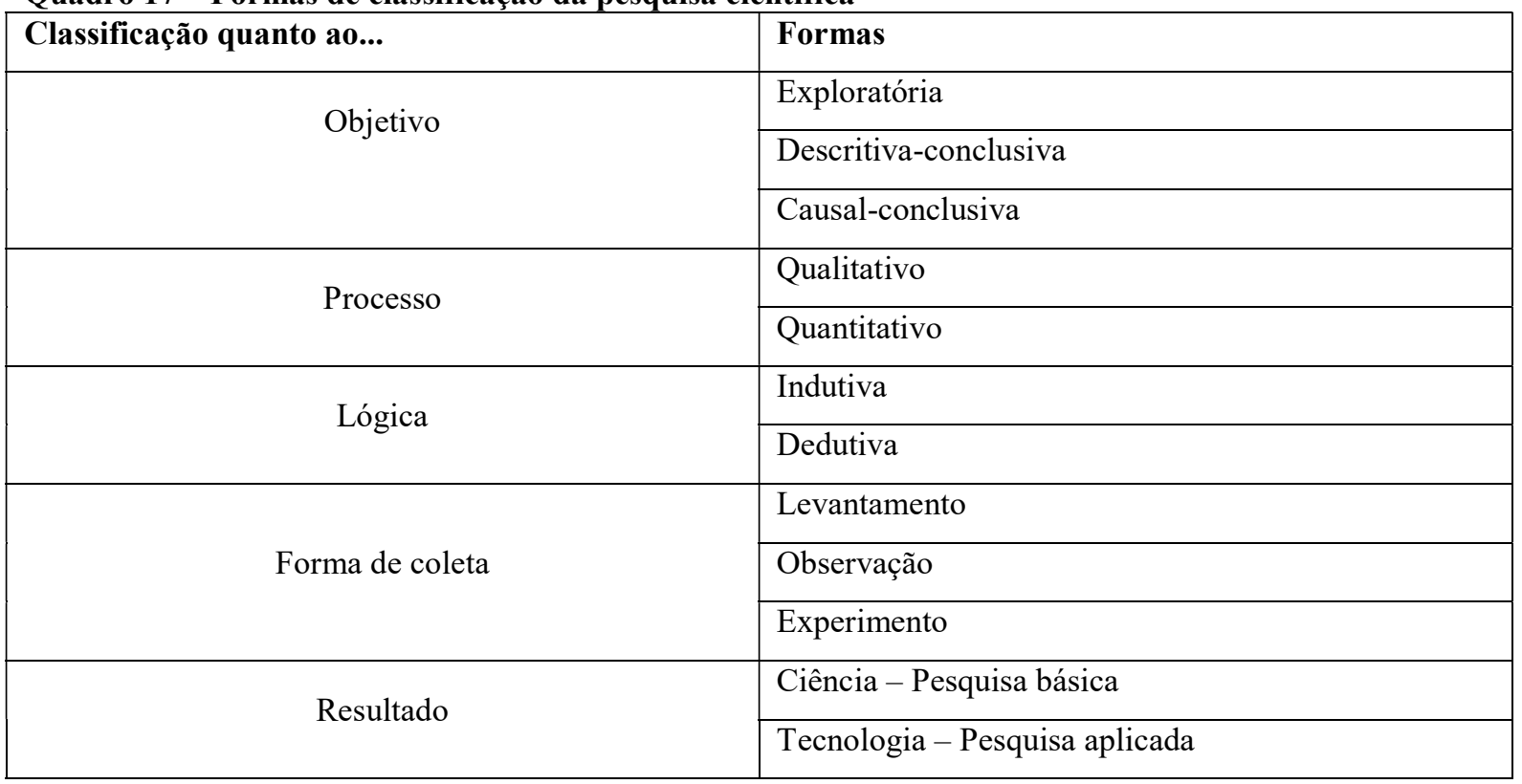

Fonte: elaborado pela autora com base em Campomar, (2013) 
O presente trabalho é classificado quanto ao seu objetivo como uma pesquisa exploratória. O processo utilizado é de caráter qualitativo, pois não enumera, não faz medições e não emprega dados estatísticos para a análise de dados (GODOY, 1995). Quanto à lógica, está classificada como de enfoque indutivo. A forma de coleta utilizada é o levantamento, com pesquisa de documentos e entrevista em profundidade. Por fim, o resultado da pesquisa tem caráter de ciência.

A pesquisa qualitativa é uma ferramenta que possibilita resolver problemas de pesquisa em temas incomuns. Este tipo de pesquisa torna possível representar o objeto de estudo de forma global e inserido em seu contexto cotidiano. Segundo Flick, (2009, p. 24) a escolha de um método de pesquisa qualitativa é determinado pelo objeto a ser estudado e está indicada quando o objetivo do estudo visa explorar um campo novo e "desenvolver teorias empiricamente fundamentadas". Os métodos mais comuns utilizados na pesquisa qualitativa são observação, estudo de caso, etnografia, grupos focais, entrevistas e grounded theory (FLICK, 2009, p. 24).

\subsection{O método de pesquisa}

Para atender ao objetivo proposto foi escolhido o método estudo de casos múltiplos. Sendo assim, a pesquisa tem caráter exploratório e qualitativo.

Para Yin (2015, p. 10) o estudo de caso pode ser definido como:

"Uma investigação empírica que investiga um fenômeno contemporâneo (o "caso") em profundidade e em seu contexto de mundo real, especialmente quando os limites entre o fenômeno e o contexto puderem não ser claramente evidentes".

É indicado quando há três condições para a pesquisa:

1. A questão utiliza a pergunta "como?" e "por quê?";

2. O comportamento relevante não seja passível de manipulação;

3. Quando os eventos são contemporâneos.

O método de estudo de caso é justificado quando a questão de pesquisa tem como foco explicar um fenômeno social de forma ampla e profunda. Para Campomar (1991) no estudo de caso ocorre uma investigação intensa de um número relativamente pequeno de situações, ou até mesmo de uma única situação. A escolha da utilização de múltiplos casos se justifica pela robustez da técnica quando comparada ao estudo de caso único. Além disso, o estudo de múltiplos casos permite a comparação entre os mesmos (YIN, 2015, p. 19). Outro ponto defendido por Campomar (1991) é que o estudo intensivo do caso permite a descoberta de 
relações que seriam impossíveis utilizando-se outros métodos. Assim, o estudo de caso é adequado para o presente trabalho.

\subsection{Unidades de análise}

Para Eisenhardt e Graebner, (2007) os casos podem ser escolhidos para completar categorias teóricas. Como o objetivo deste estudo tem o enfoque em empresas do setor farmacêutico, os casos selecionados foram de quatro indústrias farmacêuticas de diferentes portes, origens, tipos de capital e linhas de produtos.

O dado mais recente sobre a quantidade de indústrias farmacêuticas no Brasil, data de 2010. Apesar de não ser um dado recente foi o único encontrado, assim segundo o Conselho Federal de Farmácia, (2010) o número de indústrias farmacêuticas no Brasil é de 532 empresas.

Para o estudo de casos múltiplos buscou-se unidades de análise que fossem diferentes entre si. Dessa forma, para a definição dos casos selecionados foram adotados os seguintes critérios:

$\checkmark$ Tamanho da empresa no mercado brasileiro: foram selecionadas duas empresas de maior porte, presentes no Quadro 14, ranking das maiores empresas farmacêuticas brasileiras, e duas de menor porte que não constam no ranking mencionado, localizado no Item 2.4, O setor farmacêutico.

$\checkmark$ Linha de produtos: houve a preferência por empresas que têm em seus portfólios produtos variados como medicamentos genérico, similar, referencia, com e sem prescrição médica, dermocosméticos e suplementos alimentares e vitamínicos.

$\checkmark$ Foco em propaganda médica: optou-se por empresas com diferentes focos de propaganda voltados a classe médica. Algumas apresentam mais grau de visitação a médicos e outras menor grau.

$\checkmark$ Origem, nacionalidade: em relação a nacionalidade, foram selecionadas duas empresas nacionais e duas multinacionais.

$\checkmark$ Conveniência: facilidade de acesso pela pesquisadora. Conforme relatado por Yin, (2015, p. 30), é necessário que o pesquisador tenha acesso aos casos potenciais. Quando o acesso não é possível pode ser preciso a alteração da questão de pesquisa. 
$\checkmark$ Área ou departamento de Trade Marketing: um quesito fundamental para responder o objetivo do presente estudo é a existência de uma área especifica ou departamento para Trade Marketing na empresa.

Após a seleção dos casos, foi enviada uma carta convite às empresas. O modelo da carta encontra-se disponível no item Apêndice. A carta convite esclarece os objetivos da pesquisa e como ocorrerá a participação do entrevistado e da empresa. É importante considerar as questões éticas nas pesquisas. Como a pesquisa envolve seres humanos, é necessário a obtenção de consentimento, solicitando formalmente a participação voluntária e alertando os participantes para a natureza do estudo (YIN, 2015, p. 82). Por este motivo alguns cuidados foram tomados. A carta convite há um esclarece de como será efetuada e disponibilizada a pesquisa. Além disso, houve concordância na participação dos entrevistados e das empresas. Também foi registrada a autorização para a inserção e divulgação do nome das empresas no trabalho, assim como do nome dos entrevistados. Estas autorizações foram documentadas via e-mail e também oralmente com gravação.

As indústrias que participaram da pesquisa de campo foram EMS, Zambon, Biolab e Sandoz. Os respondentes das entrevistas foram gerentes e coordenadores do departamento de Trade Marketing. Na Tabela 1 foram relacionados os critérios adotados para a seleção das unidades de análise das empresas mencionadas.

Tabela 1 - Relação entre os critérios adotados para seleção das unidades de análise e empresas

\begin{tabular}{|c|c|c|c|c|}
\hline Critério & EMS & Zambon & Biolab & Sandoz \\
\hline Tamanho & $\begin{array}{l}2^{\mathrm{a}} \text { maior empresa } \\
\text { farmacêutica no } \\
\text { mercado brasileiro }\end{array}$ & $\begin{array}{l}\text { Não consta no } \\
\text { ranking }\end{array}$ & $\begin{array}{l}10^{\mathrm{a}} \text { maior empresa } \\
\text { farmacêutica no } \\
\text { mercado brasileiro }\end{array}$ & $\begin{array}{l}\text { Não consta no } \\
\text { ranking }\end{array}$ \\
\hline \multicolumn{5}{|l|}{ Linha de Produtos } \\
\hline $\begin{array}{r}\text { Medicamentos } \\
\text { Genéricos }\end{array}$ & $\mathrm{X}$ & & & $\mathrm{X}$ \\
\hline $\begin{array}{r}\text { Medicamentos } \\
\text { Similares }\end{array}$ & $\mathrm{X}$ & $\mathrm{X}$ & $\mathrm{X}$ & $\mathrm{X}$ \\
\hline $\begin{array}{r}\text { Medicamentos } \\
\text { Referência }\end{array}$ & & $\mathrm{X}$ & $\mathrm{X}$ & $\mathrm{X}$ \\
\hline $\begin{array}{r}\text { Medicamentos } \\
\text { Isentos de } \\
\text { Prescrição }\end{array}$ & $\mathrm{X}$ & $\mathrm{X}$ & $\mathrm{X}$ & $\mathrm{X}$ \\
\hline Com prescrição & $\mathrm{X}$ & $\mathrm{X}$ & $\mathrm{X}$ & $\mathrm{X}$ \\
\hline Suplementos & $\mathrm{X}$ & & $\mathrm{X}$ & \\
\hline Dermocosméticos & & & $\mathrm{X}$ & \\
\hline $\begin{array}{l}\text { Foco } \\
\text { propaganda } \\
\text { médica }\end{array}$ & & $\mathrm{X}$ & $X$ & \\
\hline Origem & Nacional & $\begin{array}{l}\text { Multinacional } \\
\text { (Itália) }\end{array}$ & Nacional & $\begin{array}{l}\text { Multinacional } \\
\text { (Suíça) }\end{array}$ \\
\hline
\end{tabular}

Fonte: elaborada pela autora. 


\subsection{Instrumento de coleta de dados}

As possíveis fontes de evidência para o estudo de caso são documentação, registro em arquivos, entrevistas, observação direta, observação participante e artefatos físicos (YIN, 2015, p. 109). A fim de responder à questão de pesquisa, as fontes de informação escolhidas foram a entrevista e a documentação.

As entrevistas são uma importante fonte de informação para o estudo de caso e podem ser definidas como conversas guiadas. Assim, as questões devem ser conversacionais, ou seja, devem ocorrer naturalmente como parte de uma conversa e não como um interrogatório. Segundo Yin (2015, p. 114) as entrevistas devem ser gravadas.

Para coleta de dados, foi desenvolvido um roteiro semiestruturado para a aplicação da entrevista baseado no roteiro utilizado por Alvarez (1999). No estudo mencionado o intuito da pesquisa era verificar as ações de Trade Marketing no setor alimentício. A elaboração do roteiro também teve como base atividades levantadas na revisão teórica. O roteiro está disponível no item Apêndice.

Foi agendada uma data e local com os entrevistados. As entrevistas duraram cerca de 60 minutos. Foram gravadas com a autorização dos entrevistados e posteriormente transcritas e analisadas.

A documentação utilizada foi principalmente o portal eletrônico das empresas. Também foram utilizados materiais comentados, pelos participantes, durante as entrevistas como aplicativos de celulares e portais de treinamentos.

\subsection{Protocolo de pesquisa}

O Protocolo de Pesquisa é um documento que contempla os procedimentos e regras adotados para a pesquisa. Sua importância se deve principalmente ao fato de aumentar a confiabilidade da pesquisa, pois orienta o pesquisador quanto ao seguimento do estudo. $\mathrm{O}$ modelo adotado para o protocolo de estudo de caso foi o proposto por Yin, $(2015$, p. 89) e está disponível no item Apêndice. 


\subsection{Análise dos dados}

A análise de dados da pesquisa qualitativa é dependente do estilo de raciocínio do pesquisador, pois não existem fórmulas e ou receitas. É necessário a apresentação de evidências suficientes e considerar interpretações alternativas (YIN, 2015, p. 137). Para Campomar (1991), a análise do estudo de caso deve ser feita por meio de analogias, comparando os casos entre si e também com o referencial teórico levantado.

A análise dos casos foi efetuada utilizando-se as categorias levantadas na revisão teórica. Conforme sugerido por Yin, (2015, p. 139) foi construída uma matriz que contempla as categorias levantadas no referencial teórico.

Os casos coletados foram analisados individualmente, com fundamento no referencial teórico. Em seguida, foi realizada a análise consolidada dos casos, por meio de comparações entre eles e com a literatura, como sugerido por Campomar (1991). A Figura 16 apresenta esquematicamente os procedimentos para a realização do estudo de caso. 
Figura 16 - Procedimentos para realização de estudo de caso

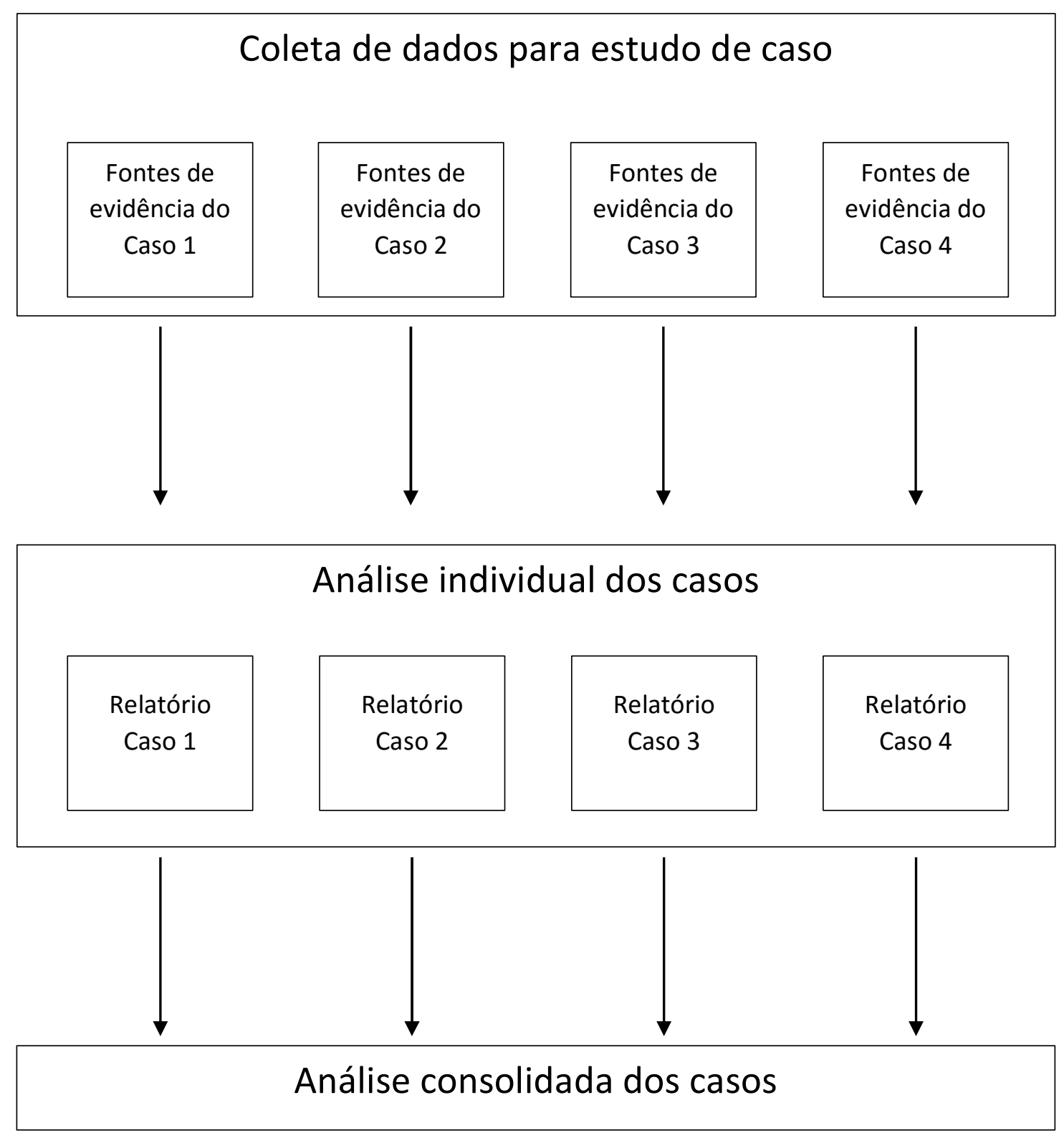

Fonte: elaborada pela autora 


\section{PESQUISA DE CAMPO: APRESENTAÇÃO E ANÁLISE DOS DADOS}

No presente capítulo pretende-se apresentar os resultados obtidos nos casos estudados e efetuar a análise de cada uma das empresas estudadas. São apresentadas, em primeiro lugar, as fontes de informação utilizadas. Em seguida, foi colocado um tópico sobre as informações gerais da empresa, contemplando seu histórico e linha de produtos, além de outros dados relevantes sobre os casos. Após as informações gerais da empresa, foi apresentada a descrição do caso, organizado de acordo com as categorias estabelecidas para elaboração do roteiro de entrevista. Por fim, a análise individual dos casos foi efetuada também utilizando-se as categorias determinadas no referencial teórico.

As análises foram realizadas demonstrando-se as práticas de Trade Marketing utilizadas em cada uma das empresas e comparando-as com as informações obtidas na revisão teórica. Após a apresentação de cada um dos casos foi efetuada a análise conjunta dos casos, comparando as empresas entre si. As categorias utilizadas foram as que emergiram tanto da revisão teórica quanto da análise dos casos, o que possibilitou atender o objetivo de pesquisa proposto. A seguir são explicados os casos das empresas EMS, Zambon, Biolab e Sandoz.

\subsection{Caso EMS}

No caso EMS foram utilizadas diversas fontes de informação, como entrevistas, consultas ao portal eletrônico da empresa e aplicativos. Um ponto importante a ser ressaltado é que a empresa tem duas divisões que contam com áreas de Trade Marketing. Assim as análises dessas duas áreas foram efetuadas separadamente devido a grande diferença existente na condução dos departamentos.

\subsubsection{Fontes de Informação}

\section{Página na internet}

EMS. Sítio da organização. Disponível em: http://www.ems.com.br/web/guest/home. Acesso em: 13 de maio de 2015 (EMS, 2015a). 
EMS GENÉRICOS. Sítio da divisão genéricos. Disponível em: http://www.emsgenericos.com.br/2015/ Acesso em: 13 de maio de 2015 (EMS GENÉRICOS, 2015a).

EMS MEDICAMENTOS EQUIVALENTES. Sítio dos medicamentos equivalentes. Disponível em: http://www.equivalentesems.com.br/. Acesso em: 14 de maio de 2015 (EMS MARCAS, 2015).

EMS. Sítio do portal de treinamentos dos módulos em foco. Disponível em: http://antimicrobianoemfoco.com.br/plataforma/. Acesso em: 12 de maio de 2015 (EMS GENÉRICOS, 2015b).

\section{Aplicativos para celulares}

EMS. Aplicativo para celular Kairos. Baixado em: 15 de maio de 2015 (EMS, 2015b).

EMS. Aplicativo para celular Mais Saúde. Baixado em: 15 de maio de 2015 (EMS, 2014).

\section{Entrevista}

Entrevista com Diego Tognonato D’Albergaria Pamplona, realizada no dia 29 de abril de 2015, na sede do Grupo NC Farma, localizado na Rodovia Jornalista Francisco Aguirre Proença, KM 08 na cidade de Hortolândia. O Sr. Diego atualmente é Coordenador de Trade Marketing da EMS Marcas. Está no cargo há 8 meses (PAMPLONA, 2015).

Entrevista com José Octávio Costa Auler Neto, realizada no dia 29 de abril de 2015, na sede do Grupo NC Farma, localizado na Rodovia Jornalista Francisco Aguirre Proença, KM 08 na cidade de Hortolândia. O Sr. José Octávio atualmente é Trainee de Trade Marketing da EMS Genéricos. Está no cargo há 1 ano (NETO, 2015).

\subsubsection{Informações gerais sobre a organização}

A EMS S.A. é uma sociedade anônima de capital fechado, constituída em 1964. A sede da empresa está localizada na cidade de Hortolândia, no estado de São Paulo, onde também possui umas das unidades produtivas. A outra está situada em São Bernardo do 
Campo. A planta fabril de Hortolândia inclui o Centro de Pesquisa \& Desenvolvimento, que é considerado um dos maiores e mais modernos centros da América Latina.

Atualmente a empresa faz parte do Grupo $\mathrm{NC}$, composto pelos laboratórios farmacêuticos Legrand, Nova Química, EMS e Germed. A empresa ainda atua no mercado norte-americano com a empresa Brace Pharma e é uma das acionistas do laboratório Bionovis, focado em medicamentos biotecnológicos. Sua atuação se dá em diversos segmentos e seus produtos contemplam prescrição médica, genéricos, medicamentos de marca, OTC e hospitalar, para praticamente todas as áreas da Medicina. A EMS exporta produtos para mais de 40 países. A empresa está agrupada em cinco unidades de negócios, sendo elas EMS Marcas, EMS Genéricos, EMS Prescrição, EMS Hospitalar e EMS OTC (EMS, 2007). É considerado o maior laboratório farmacêutico do Brasil, tanto em unidades de medicamentos vendidos quanto em faturamento.

Além disso, é EMS a segunda maior empresa farmacêutica da América Latina. No ano de 2014 as vendas totalizaram R\$ 2. 169.000,00 e participação no mercado foi de 12,7\% em vendas e 13,7\% em unidades (IMS HEALTH, 2014). Dentre as cinco divisões existentes, nem todas possuem atividades de Trade Marketing. A EMS Hospitalar tem como canal os hospitais, portanto não tem Trade Marketing. Já a divisão EMS Prescrição foca-se na propaganda médica, mas tem uma equipe chamada PDV, a qual é responsável por realizar vendas e comunicação dos produtos. Além disso, os propagandistas da EMS Prescrição efetuam algumas visitas às lojas, mas a divisão não possui uma área específica de Trade Marketing. O mesmo ocorre com a EMS OTC. A EMS Genéricos e EMS Marcas são as que contém uma área específica. Dessa forma, estas duas divisões foram o alvo da pesquisa de campo.

\subsubsection{Descrição e análise do caso EMS Marcas}

Para a descrição e análise do caso foram compilados os dados específicos sobre a divisão e foi descrita a linha de produtos pertencentes a EMS Marcas, com o objetivo de apresentar a proporção entre os produtos. Por este motivo, a linha foi separada em medicamentos isentos de prescrição, medicamentos sob prescrição, suplementos alimentares e cosméticos. Vale salientar que esta divisão não atua com medicamentos genéricos, referência ou inovação, sendo seu principal foco os medicamentos equivalentes. Em seguida, os dados obtidos nas fontes de informação foram separados de acordo com os temas utilizados no 
roteiro de entrevistas e analisados sem intenção de julgar quais as melhores ou piores práticas, mas sim comparando-os com o referencial teórico.

A divisão EMS Marcas iniciou suas atividades junto com a criação do Laboratório EMS. Esta unidade de negócio trabalha com linha de produtos das categorias suplementos alimentares, cosméticos e medicamentos. A categoria de medicamentos é composta por produtos com prescrição médica e medicamentos isentos de prescrição médica. No quadro 17 estão relacionadas as marcas de produtos e classificadas de acordo com a forma como foram registrados perante à ANVISA, em medicamentos isentos de prescrição, medicamentos sob prescrição, suplementos alimentares e cosméticos.

\section{Quadro 18 - Linha de produtos EMS Marcas}

\begin{tabular}{|c|c|}
\hline $\begin{array}{l}\text { Medicamentos } \\
\text { Isentos de Prescrição }\end{array}$ & 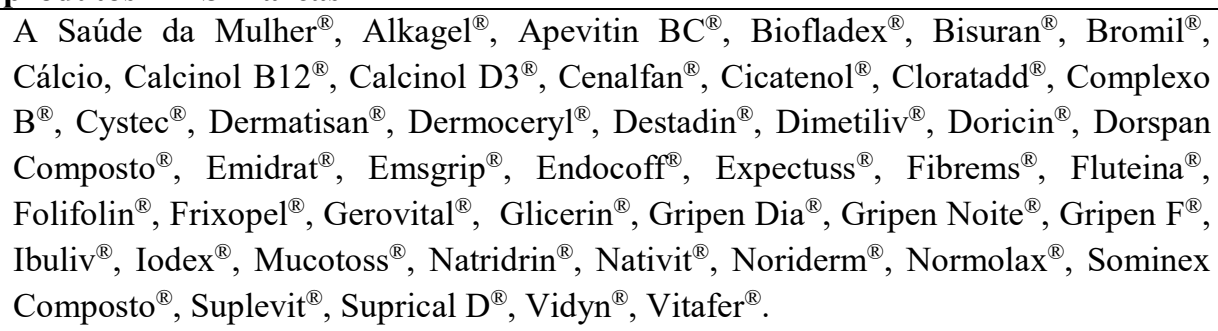 \\
\hline $\begin{array}{l}\text { Medicamentos sob } \\
\text { Prescrição Médica }\end{array}$ & 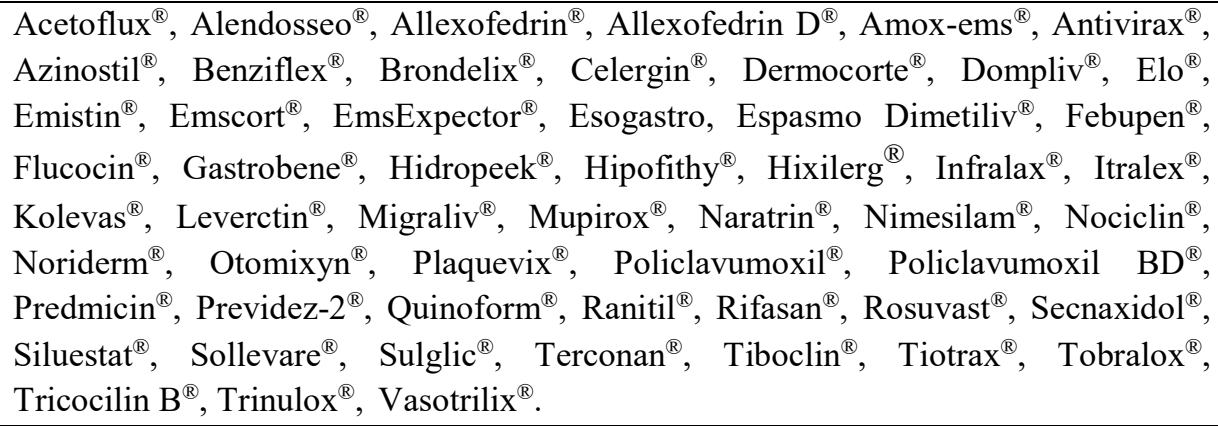 \\
\hline $\begin{array}{l}\text { Suplementos } \\
\text { Alimentares }\end{array}$ & Gerovital Phytus $^{\circledR}$, Natuless $^{\circledR}$, Óleo de Cártamo. \\
\hline Cosméticos & Higiderm $^{\circledR}$, Pomaglós Amendoas ${ }^{\circledR}$. \\
\hline
\end{tabular}

Fonte: elaborado pela autora com base em dados fornecidos pela empresa.

\subsubsection{Estrutura Organizacional}

Em relação à estrutura organizacional da divisão, no que concerne ao Trade Marketing não há um departamento específico na EMS Marcas. Entretanto, existe uma área de Trade Marketing que está subordinada à gerência de Marketing. Assim, a estrutura corrobora com os estudos que afirmam que o Trade Marketing pode estar subordinado ao departamento de marketing (MOTTA; SANTOS; SERRALVO, 2008, p. 103; RANDALL, 1994, p. 127; ZEYL; ZEYL, 1997, p. 177) 
A área existe há cerca de quatro anos na divisão, porém no último ano houve uma reestruturação das atividades executadas, com foco em estratégias e não somente na parte operacional. Pamplona, (2015) comenta que, como é uma área nova na empresa, ainda é muito focada em merchandising e em materiais de comunicação no PDV. Entretanto a empresa está efetuando mudanças na área e ampliando as atividades e, assim, trazendo uma visão mais estratégica para o Trade Marketing. Dessa forma, a área passa do enfoque, apresentado por Cônsoli e D'Andrea, (2010, P. 53), operacional, responsável pelo merchandising e promoção, para uma área estratégica de planejamento de vendas e canais.

Existem quatro coordenadores de Trade Marketing, sendo um interno e três externos. O coordenador interno é responsável pelo que chamam de Inteligência de Trade Marketing, que cuida da análise de informações para fornecer suporte ao departamento comercial. Os coordenadores externos são responsáveis pela gestão dos promotores, que por sua vez são os responsáveis por efetuar a visita nos pontos de venda. São atendidos pelos promotores cerca de 3.200 farmácias. Atualmente, a força de venda da divisão é principalmente via distribuidor. Entretanto em São Paulo existe uma equipe de vendas direta.

A área de Trade Marketing é vista, principalmente, como uma ponte entre o departamento de marketing e o comercial, cujo objetivo final é ser um gerador de demanda. Esta visão de integração entre os departamentos de marketing e o comercial corrobora com Alvarez, (1999) que comenta sobre o papel do Trade Marketing como um elo entre os departamentos de vendas e marketing.

\subsubsection{Segmentação dos canais}

A segmentação dos pontos de venda na EMS Marcas é efetuada por meio de uma matriz, que cruza potencial de compras com o market share do varejista. São definidos alguns perfis de lojas, sendo que os principais clientes, com alto potencial e alto market share, não necessariamente as grandes redes, pois este perfil é gerado por loja. Esta atividade corrobora com a literatura, que afirma que o departamento de Trade Marketing deve efetuar a segmentação dos canais (ALVAREZ, 2008, p. 104; CÔNSOLI; D'ANDREA, 2010, p. 128). Entretanto, o objetivo da segmentação citado por Campomar e Ikeda (2006, p. 13), deve ser a atuação de forma diferenciada em cada segmento, no caso da EMS Marcas, é efetuada apenas pelo departamento comercial, pois as ações de Trade Marketing não são customizadas. Também não é utilizado o princípio de marketing one to one, como sugerido por Alvarez, 
(2008, p. 104). A segmentação dos pontos de vendas também considera a região na qual estão inseridos como proposto por Alvarez, (2008, p. 104)

\subsubsection{Sistema de Informação de Trade Marketing}

$\mathrm{Na}$ área existe uma atividade que é chamada Inteligência de Trade Marketing. Esta função desempenhada consiste em analisar informações compradas de fornecedores externos ou provenientes de registros internos. Os dados são comprados de empresas como Nielsen e IMS Health. As informações analisadas pelo Trade Marketing são referentes ao canal de distribuição e servem como base para segmentação dos clientes e alimentação do sistema de informação de vendas, principalmente.

O uso da palavra inteligência neste caso contraria o que é descrito na literatura de sistemas de informação de marketing: a Inteligência de Trade Marketing efetua análise do sistema de registros internos também (CAMPOMAR; IKEDA, 2006, p. 34; CHIUSOLI, 2005). Além disso não efetuam a coleta de dados de inteligência, como treinamento da equipe de vendas para que relate acontecimentos, motivar os canais para passar informações importantes, monitoramento de informações sobre ações de concorrentes, comprar informações de fornecedores externos citados por Kotler e Keller, (2006, p. 73). Na EMS Marcas não existe um treinamento formal ou um formulário para que o promotor colete informações de inteligência no campo para alimentar o sistema de informações. Entretanto pensam em fazer isso no futuro.

Em relação ao sistema de informações de Trade Marketing da EMS Marcas, nota-se que a principal atividade desenvolvida é a análise de informações compradas e dos registros internos, principalmente com relação a vendas. Este fato corrobora com as atividades de sistema de informação de Trade Marketing apresentadas por Alvarez, 2008, p. 119).

\subsubsection{Comportamento do Shopper}

A EMS Marcas começou a realizar a análise de comportamento do shopper recentemente. Trabalham com a investigação sobre decisão de compra dos produtos, corroborando parcialmente com a literatura sobre o tema (CÔNSOLI; D'ANDREA, 2010, p. 129). Entretanto, essa análise na empresa é de responsabilidade, principalmente, do marketing. 


\subsubsection{Produto}

A influência sobre o mix de produtos do varejista é de forma indireta, por meio de suporte ao departamento comercial. O Trade Marketing consegue analisar informações e verificar quais produtos pertencem ou não ao mix do varejista e quais produtos tem potencial para determinado varejista adotar no seu mix de produtos. Esta atividade corrobora com a descrita por Alvarez, $(2008$, p. 86, 90, 142) sobre adequação do mix de produtos de acordo com o perfil do cliente.

Em relação à avaliação de concorrentes, linha de produtos, otimização da linha e aplicação das estratégias de marketing no ponto de venda, apresentadas por (ALVAREZ, 2008, p. 91). Na EMS Marcas ainda não há um treinamento formal dos representantes para trazer estas informações do ponto de venda para dentro da empresa. Entretanto, em alguns casos, o representante pode ser proativo e enviar informações do ponto de venda que serão analisadas e distribuídas.

A performance da embalagem do produto, comentada por Alvarez, (2008, p. 91); Motta, Santos e Serralvo (2008, p. 54), no ponto de venda ainda não é monitorada pelos representantes. Entretanto, quando há algum problema com o desempenho de um produto é solicitado que os profissionais que visitam as lojas façam uma avaliação de possíveis causas. Esse fato pode ser exemplificado pelo seguinte caso descrito por Pamplona (2015):

"Tivemos um problema com um produto que perdeu muita visibilidade, o Naridrin. Descobrimos que o varejista virava embalagem, só que não estava escrito Naridrin na lingueta de cima da caixa. Foi um insight do campo." (PAMPLONA, 2015)

Além disso, é comum na empresa que, ao desenvolver uma ação ou alterar a embalagem, o departamento de marketing solicite uma avaliação do departamento de Trade Marketing para que haja uma visão também sobre a performance da ação no canal. Isso vai ao encontro do apoio e suporte às ações de marketing citadas por Alvarez, (2008, p. 90).

\subsubsection{Preço}

Em relação a formação de preço não há influência direta. A formação de preço é responsabilidade do departamento comercial que pode obter informações com o Trade Marketing. Pamplona (2015) ilustrou esta questão com o seguinte caso:

“Ocorrerá a Corrida Santa Lúcia no Espírito Santo e nós vamos promover um produto. Pedimos para a promotora fazer um levantamento de preço do nosso produto e concorrentes nas lojas da região. O nosso produto perdia para o produto que é referência. Fizemos esse estudo e o 
nosso preço perdia para todos os produtos concorrentes. Passamos esta informação para o departamento comercial. O comercial entra em contato e tenta negociar com o varejista."

Este ocorrido está de acordo com uma das atividades referentes a preço descritas por Alvarez, (2008, p. 92) que é acompanhar os preços praticados pelos clientes e orienta-los.

Outra preocupação em relação a preços é manter a atratividade do produto para o consumidor. Pamplona (2015) coloca o exemplo do Gerovital ${ }^{\circledR}$ : o preço de fábrica é cerca de $\mathrm{R} \$ 108,00$, mas o preço praticado é em média de $\mathrm{R} \$ 49,00$. Se a farmácia colocar o preço de fábrica, não venderá o produto. Também foi comentado um episódio de conflito de canais por causa de preço. Um varejista colocou um preço tão baixo em um determinado produto que o tornou mais barato que o preço praticado pelo distribuidor.

Pamplona (2015) comenta que há casos em que precisa conversar com o varejista para aumentar ou diminuir o preço praticado. Esta atividade narrada corrobora com o descrito na literatura. (ALVAREZ, 2008, p. 92) As demais atividades descritas na teoria, como acompanhamento constante dos preços e movimentação dos concorrentes não são aplicadas de forma regular, como sugerido na literatura (ALVAREZ, 2008, p. 92) .

\subsubsection{Comunicação}

As atividades desenvolvidas em relação à comunicação pela área de Trade Marketing da EMS Marcas corroboram com as descritas pela literatura, como o desenvolvimento de promoções de vendas (ALVAREZ, 2008, p. 144; MOTTA; SANTOS; SERRALVO, 2008, p. 62), merchandising (ALVAREZ, 2008, p. 144; MOTTA; SANTOS; SERRALVO, 2008, p. 62), materiais de ponto de venda (CÔNSOLI; D'ANDREA, 2010, p. 162), inserção em tabloides (MOTTA; SANTOS; SERRALVO, 2008, p. 62; ROSENBLOOM, 2008, p. 306; ROSLOW; LASKEY; NICHOLLS, 1993) e eventos (FERRACCIÙ, 2007, p. 59; ROSENBLOOM, 2008, p. 315). A venda direta é uma atividade de responsabilidade do departamento comercial.

Outro ponto relacionado à comunicação é a negociação com o canal. Estas negociações englobam a posição dos produtos nas gôndolas, inserção de materiais de comunicação no PDV e inserção em tabloides do varejista. Esta negociação é efetuada em parceria entre a área de trade marketing e o departamento comercial. Em alguns casos são efetuadas pelo Key Account e são aprovadas pela área de Trade Marketing. Quando se trata de uma rede localizada em São Paulo um coordenador da área de Trade Marketing pode ir o cliente junto com o departamento comercial a para dar suporte na negociação. 
Já a fiscalização da negociação é baixa. Se existe um promotor que visita a loja fica a cargo dele verificar se o varejista cumpriu com o contrato negociado. Mas em lojas que não recebem visita do promotor, não há fiscalização da ação.

As feiras e eventos do setor farmacêutico que têm como público alvo distribuidores e varejistas, são organizada pelo departamento de Trade Marketing. O comercial escolhe as feiras que a divisão participará e passa para o Trade Marketing. Este realiza a organização da feira em conjunto com o departamento de eventos, corroborando com a literatura de canais de distribuição e marketing promocional (FERRACCIÙ, 2007, p. 59; ROSENBLOOM, 2008, p. $315)$.

\subsubsection{Gerenciamento de Categorias}

A área de Trade Marketing da divisão EMS Marcas, até o momento, não desenvolve atividades relacionadas ao gerenciamento de categorias. Este fato reflete em parte a literatura sobre o tema (ALVAREZ, 2008, p. 67).

\subsubsection{Relacionamento com o canal}

As atividades que dizem respeito a relacionamento com os canais de distribuição foram investigadas em dois blocos. O primeiro trata-se de ações efetuadas para o varejista e o segundo em relação as ações efetuadas em parceria com os varejistas.

A divisão EMS Marcas tem enfoque apenas no canal varejista. Foi comentado que, até o ano de 2013, o Trade Marketing era como um "braço" do atacadista. A equipe de campo visitava as lojas determinadas pelos distribuidores. A partir de 2014, houve a reestruturação da área e implantação de ferramentas que possibilitaram verificar a demanda da farmácia e direcionar a equipe para as lojas de interesse.

Para Cônsoli e D'Andrea (2010, p. 117) programas de suporte, como treinamentos e a participação no processo de remuneração, podem ser oferecidos pelos produtores para as equipes dos canais. Dessa forma a equipe do canal é vista como uma extensão da equipe de vendas do produtor. Os treinamentos presenciais são um foco da EMS Marcas. Os temas são demandados pelos varejistas e, por este motivo, são customizados, como descrito por Rosenbloom, (2008, p. 312). Existem alguns treinamentos-padrão como, por exemplo, o tema Inverno, que aborda os tipos de tosse e como tratá-las. O programa de treinamentos realizados pela empresa receberam o nome de Serenus. 
Entretanto, a responsabilidade pelos treinamentos é de um departamento específico de treinamento, que não está dentro da área de Trade Marketing, mas que trabalha em parceria. Os treinamentos são focados não em produtos, mas, principalmente, no desenvolvimento do balconista, pois a empresa percebeu que estes profissionais criam uma barreira se o treinamento for sobre produtos. O trecho abaixo ilustra a preocupação com o treinamento da equipe do varejo:

"Quanto mais assertivo o balconista é na resolução do problema do cliente, maior a taxa de retorno e mais sucesso na farmácia. Assim, o balconista tende a crescer, então nós estamos dando serviço para que esse cara cresça para que ele seja bom no que ele faz. Prezamos muito mais o serviço" (PAMPLONA, 2015).

Uma ação desenvolvida pelo Trade Marketing efetuada para os varejistas foi o lançamento de um aplicativo de celular e do portal eletrônico dos medicamentos equivalentes. Perceberam que haviam muitas dúvidas entre os balconistas e farmacêuticos em relação ao que pode e o que não pode ser feito segundo a legislação de equivalentes. Esse foi o primeiro trabalho digital desenvolvido.

As campanhas de incentivo e participação no processo de remuneração do canal não são feitas. Há uma grande preocupação por parte da empresa em seguir as determinações legais e, uma vez que esta prática não é permitida pela legislação do setor, a empresa não a aplica. Entretanto, este fato contraria a literatura que menciona os programas de incentivo (CÔNSOLI; D’ANDREA, 2010, p. 120).

Em relação a ações desenvolvidas em colaboração com os canais, ainda são inexistentes: não há compartilhamento de informações com os varejistas, utilização de indicadores de desempenho em conjunto, um sistema de abastecimento automático, promotores exclusivos para os principais clientes ou ações de lançamento de produto dedicado aos principais clientes. Isso contraria a literatura levantada (CÔNSOLI; D'ANDREA, 2010, p. 120).

\subsubsection{Plano de Trade Marketing}

Não há um Plano de Trade Marketing. Entretanto, há uma apresentação que contempla metas, cronograma e programa de ação. O orçamento de Trade Marketing está inserido no orçamento de marketing. Por esse motivo, é difícil fazer um planejamento anual. Além disso, 
as ações são realizadas de acordo com a demanda. O plano da forma como é descrito por Alvarez, (2008, p. 123) para os cliente-chave ou segmentos de clientes não é efetuado.

\subsubsection{Métricas de Trade Marketing}

O conceito de Return on Investment (ROI) não era utilizado na empresa, mas atualmente estão implantando este indicador, como comentado por Cônsoli e D'Andrea (2010, p. 234). Como exemplo, foi citado que às vezes o vendedor negociava uma caixa de um produto e dava um brinde para o varejista que valia mais que o medicamento vendido. Ultimamente a empresa trabalha no sentido de desenvolver e utilizar as métricas para verificar tanto o desempenho quanto a efetividade das ações.

A empresa acompanha o resultado de vendas, participação de mercado e rentabilidade como sugerido pela literatura (MOTTA; SANTOS; SERRALVO, 2008, p. 83). Também acompanha os dados de selling in e selling out cometados por Alvarez (2008, p. 136).

\subsubsection{Outras considerações}

O maior desafio apontado foi convencer o departamento de marketing e o departamento comercial que a área de Trade Marketing é importante. O Trade Marketing ainda é visto pelo comercial como um fornecedor de material de comunicação no PDV. A parte digital da divisão é uma atividade atribuída aoTrade Marketing na empresa.

A legislação do setor não foi apontada como um grande impedimento para as atividades de Trade Marketing. Inclusive houve o seguinte comentário de Pamplona (2015) em relação a legislação:

"Eu vejo como mais complicado para o marketing trabalhar o produto do que para o Trade Marketing”.

\subsubsection{Descrição e análise do caso EMS Genéricos}

A divisão EMS Genéricos foi criada no ano 2000 e atualmente tem cerca de 500 apresentações. A linha de genéricos da empresa contém tanto medicamentos isentos de prescrição quanto medicamentos sob prescrição que estão relacionadas no Quadro 19. As 
fontes de informação consultadas na EMS Genéricos foram o portal eletrônico da divisão e entrevista com Neto (2015), trainee do departamento de Trade Marketing.

Quadro 19 - Linha de produtos EMS Genéricos.

Medicamentos genéricos isentos de prescrição

Medicamentos genéricos sob prescrição
Aceclofenaco, acetilcisteína, ácido acetilsalicílico, albendazol, butilbrometo de escopolamina+dipirona sódica, carbicisteína, cetoconazol, cetoprofeno, citrato de orfenadrina+dipirona monoidratada+cafeína, cloridrato de ambroxol, cloridrato de bromexina, cloridrato de terbinafina, clotrimazol, diclofenaco dietilamônio, diclofenaco sódico, dipirona sódica, hidróxido de alumínio, ibuprofeno, loratadina, maleato de dexclorfeniramina, nimesulida, nistatina+óxido de zinco, nitrato de miconazol, paracetamol, paracetamol+cafeína, piroxicam, simeticona, sulfato de neomicina+bacitracina.

Acebrofilina, aceclofenaco, acetato de dexametasona, acetonido de triancinolona+sulfato de neomicina+gramicidina+nistatina, aciclovir, ácido mefenamico, ácido tranexamico, adapaleno gel, alendronato de dódio, algestona acetofenida+ enantato de estradiol, atenolol, atenolol+clortalidona, atorvastatina cálcica, besilato de anlodipino, betametasona, bezafibrato, bimatoprosta, bissulfato clopidogrel, brometo de pinavério, brometo de ipatrópio, bromoprida, candersartana, candesartana+hidroclortiazida, captopril, carvedilol, cetoconazol, cetoconazol+dipropionato de betametasona, ciclopirox olamina, citrato de sildenafila, cloridrato de ticlopidina, cloridrato de ciclobenzaprina, cloridrato de dorzolamida, cloridrato de dorzolamida+maleato de timolol, cloridrato de amilorida+hidroclorotiazida, cloridrato de amilorida+hidroclortiazida, cloridrato de diltiazem, cloridrato de fenoxazolina, cloridrato de hidroxizina, cloridrato de lidocaína, cloridrato de metformina, cloridrato de nafazolina, cloridrato de naratriptana, cloridrato de oxibutinina, cloridrato de oximetazolina, cloridrato de ranitidina, cloridrato de terbinafina, cloridrato de tetraciclina_anfotericina B, cloridrato de verapamil, clortalidona, clotrimazol, deflazacorte, desloratadina, desonida, dexametasona, diclofenaco colestiramina, diclofenaco postássico, diclofenaco sódico, dimeticona+metilbrometo de homatropina, dipropionato de betametasona, dipropionato de betametasona+ácido salicílico, domperidona, dropirenona+etinilestradiol, esomeprazol, espirolactona, fenofibrato, finasterida, fluconazol, fumarato de bisoprolol, fumarato de cetotifeno, furoato de mometasona, genfibrozila, glibenclamida, glimepirida, hidroclortiazida, hidrocortisona, hidroquinona+tretinoína+ fluocinolona acetonida+hidroquinona+indapamida, lanzoprazol, latanoprosta, lidocaína, lisinopril, loratadina+sulfato de pseudoefedrina, losartana postássica, losartana potássica+hidroclortiazida, maleato de timolol, meloxicam, mesalazina, mesilato de doxasina, metildopa, nimesulida, nimodipino, nistatina, nitrato de fenticonazol, nitrato de isoconazol, nitrato de miconazol, omeprazol, pantoprazol, 


\begin{tabular}{|l|l|}
\hline & $\begin{array}{l}\text { paracetamol+cloridrato de pseudoefedrina, pentoxifilina, pioglitazona, piroxicam, } \\
\text { prednisolona, prednisona, propionato de clobetasol, repaglinida, risedronato } \\
\text { sódico, rosuvastatina cálcica, secnidazol, sinvastatina, sulfato de salbutamol, } \\
\text { sulfato de salbutamol+guaifenesina, telmisartana, tenoxicam, terconazol, tibolona, } \\
\text { tinidazol, tinidazol+nitrato de miconazol, tioconazol+tinidazol, travoprosta, } \\
\text { trometamol cetorolaco, valerato de betametasona, valsartana, } \\
\text { valsartana+hidroclortiazida, alprazolam, bramazepam, bromidrato de citalopram, } \\
\text { carbamazepina, clonazepam, cloridrato de paroxetina, cloridrato de venlafaxina, } \\
\text { cloridrato de amitriptilina, cloridrato de bupropiona, cloridrato de clomipramina, } \\
\text { cloridrato de fluoxetina, cloridrato de sertralina, cloridrato de tramadol, cloridrato } \\
\text { de venlafaxina, dicloridrato de pramipexol, fumarato de quetiapina, gabapentina, } \\
\text { hemifumarato de quetiapina, hemitartarato de zolpidem, hemitartarato de } \\
\text { rivagmina, isotretinoína, lorazepam, olazapina, oxalato escitalopram, risperidona, } \\
\text { topiramato, valproáto de sódio. }\end{array}$ \\
\hline
\end{tabular}

Fonte: elaborado pela autora com base em EMS Genéricos (2015a)

\subsubsection{Estrutura Organizacional}

Na divisão EMS Genéricos o Trade Marketing é um departamento que responde ao diretor de marketing. Neste caso, o departamento é independente, entretanto está subordinado ao marketing. Este fato corrobora com a literatura sobre os tipos de estrutura de Trade Marketing (MOTTA; SANTOS; SERRALVO, 2008, p. 103; RANDALL, 1994, p. 127; ZEYL; ZEYL, 1997, p. 177).

$\mathrm{O}$ departamento existe à cerca de cinco anos e foi a primeira divisão a ter um departamento de Trade Marketing. A estrutura é composta por um gerente de Trade Marketing e mais quatro pessoas que trabalham com Inteligência de Trade Marketing. A visitação a loja é feita pelos representantes de vendas. Em relação aos representantes, Neto (2015) ressaltou:

"O representante vai na loja para garantir a frequência e presença. A demanda é feita pela negociação, mas quem vai fazer a venda é o representante que está fazendo o relacionamento. Na farmácia independente é diferente: você tem que trabalhar a demanda, colocar o produto e ajudar o cara a vender. Nas redes não, a demanda já é pré-acordada e você tem que puxar a venda."

O fato de ser o representante quem visita os pontos de vendas diverge do esperado, que seria ter um promotor de vendas para efetuar a visita e desenvolver relacionamento com os pontos de vendas. 


\subsubsection{Segmentação dos canais}

A segmentação de canais na EMS Genéricos também é efetuada pela análise da atratividade do cliente, como sugerido por Consoli e D'Andrea (2010, p. 128). Além disso, é verificado por região quais as farmácias que têm mais retorno para a empresa. Também ocorre um mapeamento de todas as farmácias do Brasil. Estas farmácias são separadas conforme a meta de cada representante.

Há também uma segmentação de acordo com o ataque e defesa do mercado. Isto ocorre quando a farmácia não tem um alto potencial, mas de alguma forma tem grande importância no mercado. Este tipo de segmentação corrobora com a literatura que afirma que os clientes podem ser segmentados de acordo com sua visibilidade (ALVAREZ, 2008, p. 104; CÔNSOLI; D'ANDREA, 2010, p. 128). Esta divisão já atua de forma a diferenciar ações de acordo com os segmentos de canais que deseja atingir, concordando com o objetivo da segmentação proposto por Campomar e Ikeda (2006, p. 13).

\subsubsection{Sistema de Informação de Trade Marketing}

Na divisão Genéricos também existe a atividade de Inteligência de Trade Marketing. É responsável por analisar informações compradas de empresas como Nielsen e IMS Health e distribuir estas informações para o departamento comercial, principalmente.

O Trade Marketing desempenha uma função de distribuição de informações para os departamentos de marketing e vendas. Entretanto a coleta sistemática de informações de inteligência sobre os canais não é executada até o momento. Este fato corrobora com as atividades de sistema de informação de Trade Marketing apresentadas por Alvarez, 2008, p. 119). Já as informações de inteligência relatadas por Kotler; Keller, (2006, p. 73) são parcialmente desenvolvidas.

\subsubsection{Comportamento do Shopper}

Na divisão Genéricos, assim como na divisão Marcas, o departamento de Trade Marketing não utiliza recursos avançados para verificar o comportamento do shopper, como câmeras ou outras ferramentas. Entretanto efetuam também análise da decisão de compras, 
corroborando parcialmente com a literatura sobre o tema (CÔNSOLI; D'ANDREA, 2010, p. 129).

\subsubsection{Produto}

A influência no mix de produto do varejista é indireta. A negociação é feita pelo departamento comercial, mas o Trade Marketing participa do processo, elaborando um dossiê do produto e suprindo o departamento comercial com informações, e corroborando com o apoio mencionado por Alvarez, (2008, p. 91). Ao ser perguntado se o representante traz as informações do PDV para a empresa, Neto (2015) explicou o seguinte:

"No mundo ideal sim, mas é correria então nós damos mais o suporte do que eles trazem informações. Quando nós vamos a campo conseguimos ter uma conversa, entender melhor o dia a dia deles."

\subsubsection{Preço}

A formação do preço de venda para o canal não é uma atividade que conta com a participação do Trade Marketing na EMS. No caso da divisão genéricos, foi comentado que é possível exercer maior influência com o varejista na formação de preços ao consumidor. Ainda não é desenvolvido um monitoramento do preço praticado pelos concorrentes no ponto de venda como sugerido pela literatura.

\subsubsection{Comunicação}

O Trade Marketing da divisão genéricos realiza atividade com relação a comunicação de forma muito parecida com a divisão Marcas. As atividades desenvolvidas vão ao encontro das descritas pela literatura, como o desenvolvimento de promoções de vendas (ALVAREZ, 2008, p. 144; MOTTA; SANTOS; SERRALVO, 2008, p. 62), merchandising (ALVAREZ, 2008, p. 144; MOTTA; SANTOS; SERRALVO, 2008, p. 62), materiais de ponto de venda (CÔNSOLI; D'ANDREA, 2010, p. 162), inserção em tabloides (MOTTA; SANTOS; SERRALVO, 2008, p. 62; ROSENBLOOM, 2008, p. 306; ROSLOW; LASKEY; NICHOLLS, 1993) e eventos (FERRACCIÙ, 2007, p. 59; ROSENBLOOM, 2008, p. 315). A venda direta é uma atividade de responsabilidade do departamento comercial. 
A negociação da posição dos produtos nas gôndolas, inserção de materiais de comunicação no PDV e inserção em tabloides do varejista também é efetuada em parceria com o departamento comercial. Os representantes fiscalizam as ações negociadas.

A EMS é uma empresa que não tinha como foco a participação em feiras e eventos. Entretanto estão mudando este posicionamento e iniciando a participação em algumas feiras do setor. O Trade Marketing da divisão genéricos auxilia na participação de feiras e eventos quando como público os varejistas e suas equipes, corroborando com a literatura (FERRACCIÙ, 2007, p. 59; ROSENBLOOM, 2008, p. 315).

\subsubsection{Gerenciamento de Categorias}

A divisão Genéricos, ao contrário da divisão Marcas, atua fortemente com o gerenciamento de categorias, auxiliando o varejista na avaliação e acompanhando os resultados das categorias. Este fato corrobora com a literatura (ALVAREZ, 2008, p. 67).

\subsubsection{Relacionamento com o cliente}

$\mathrm{Na}$ divisão genérico, dentre as atividades desenvolvidas para os varejistas e atacadistas, o Trade Marketing fornece diversos treinamentos para os canais de distribuição. O programa de treinamento é chamado Academius e contempla treinamentos presenciais e módulos de treinamentos em fascículos. Tem como foco toda a cadeia de distribuição, como farmacêuticos, balconistas, gerentes e distribuidoras. Existem treinamentos separados para todos os públicos, que abordam tanto temas técnicos como temas de gestão, como por exemplo merchandising, gestão financeira, sistema nervoso central, sistema cardiovascular, corroborando com a literatura (CÔNSOLI; D'ANDREA, 2010, p. 117; ROSENBLOOM, 2008, p. 312).

Além disso, também foram desenvolvidos aplicativos para celulares, chamados Mais Saúde e Kairos. Estes aplicativos têm enfoque na equipe do canal. Há um portal com os treinamentos dos módulos, chamados Em Foco. Contempla os temas antimicrobianos, sistema nervoso e cardivascular. Estes têm como público-alvo a equipe da farmácia.

As demais ações de relacionamento com o canal citadas na literatura não são desenvolvidas, como participação no processo de remuneração e incentivos. Já que não são legalmente autorizadas. Os programas de suporte, compartilhamento de informações com o 
canal e uso de indicadores em conjunto também não são desenvolvidos até o momento, contrariando a literatura sobre o tema (CÔNSOLI; D'ANDREA, 2010, p. 117).

\subsubsection{Plano de Trade Marketing}

Na divisão Genéricos também não há um Plano de Trade Marketing. Entretanto há uma apresentação que contempla metas, cronograma e programa de ação. O orçamento de Trade Marketing é próprio do departamento. O plano da forma como é descrito por Alvarez, (2008, p. 123) para os cliente-chave ou segmentos de clientes não é efetuado.

\subsubsection{Métricas de Trade Marketing}

Assim como a divisão Marcas, a divisão Genéricos acompanha o resultado de vendas, participação de mercado e rentabilidade, como sugerido por Motta, Santos e Serralvo (2008, p. 83). Também acompanha os dados de selling in e selling out comentados por Alvarez (2008, p. 136). Outro indicador utilizado é o ROI, descrito por Cônsoli e D'Andrea, (2010, p. 234).

\subsection{Caso Zambon}

No caso Zambon foram utilizadas como fontes de informação, entrevista e consultas ao portal eletrônico da empresa. Há apenas um departamento de Trade Marketing na empresa.

\subsubsection{Fontes de informação}

\section{Página na internet}

ZAMBON. Sítio da organização no Brasil. Disponível em: http://www.zambon.com.br/br/zbr-home/zc-home/entry/0/936/0/home-page.html Acesso em: 23 de maio de 2015 (ZAMBON, 2015a).

ZAMBON. Sítio global da organização. Disponível em: http://www.zambongroup.com/it/zchome/zc-home/entry/0/190/1/default.html Acesso em: 23 de maio de 2015(ZAMBON, 2015b). 
ZAMBON. Sítio da global da divisão farma. Disponível em: http://www.zambonpharma.com/it/zspa-homespa/zc-home/entry/0/241/0/default.html. Acesso em: 23 de maio de 2015 (ZAMBON, 2015c).

\section{Entrevista}

Entrevista com Alan Tosetto, realizada no dia 28 de abril de 2015, na sede do Zambon, localizado na Avenida Ibirapuera, 2332, na cidade de São Paulo. O Sr. Alan é o Gerente de Comercial e Trade Marketing do laboratório Zambon. Atua no cargo há 2 anos (TOSETTO, 2015).

\subsubsection{Informações Gerais sobre a organização}

A história do laboratório Zambon tem início em 1906, quando seu fundador inaugura um depósito de medicamentos em Vicenza, na Itália. Atualmente, o grupo Zambon conta com duas divisões: uma farmacêutica e outra de química fina. No Brasil, o laboratório se instalou no ano de 1956, apenas com a divisão farmacêutica. O Brasil representa a quarta maior operação da companhia no mundo. A unidade fabril está localizada em Itapecerica da Serra e o escritório localizado no bairro de Moema, em São Paulo. No ano de 2011 a empresa faturou R\$ 158,2 milhões no Brasil.

A empresa conta com 155 representantes e sua linha de produtos contempla tanto medicamentos sob prescrição médica quanto os isentos de prescrição. O laboratório não possui linha de produtos genéricos, sendo seu portfólio composto por medicamentos referência, inovação e alguns similares. O Quadro 20 apresenta a linha de produtos do laboratório Zambon.

Quadro 20 - Linha de produtos Zambon.

\begin{tabular}{|c|c|}
\hline Medicamentos sob prescrição & 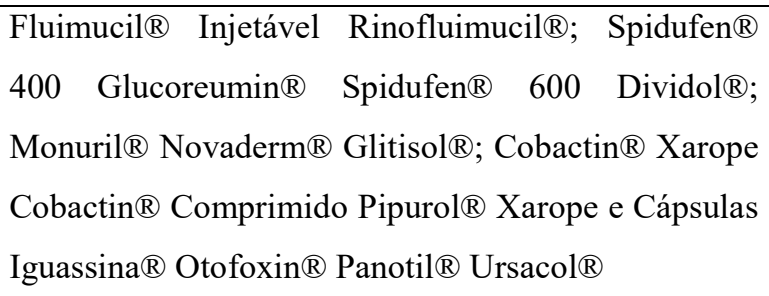 \\
\hline Medicamentos isentos de prescrição & $\begin{array}{l}\text { Fluimare }^{\mathrm{TM}} \text { Fluimare }{ }^{\mathrm{TM}} \mathrm{HT} \text { Fluimucil } \AA \text {; Fluimucil }{ }^{\circledR} \\
\text { Nasal; Seki }{ }^{\circledR}\end{array}$ \\
\hline
\end{tabular}

Fonte: Elaborado pela autora com base em Zambon, 2015. 


\subsubsection{Descrição e análise do caso Zambon}

\subsubsection{Estrutura Organizacional}

Nos últimos três anos o laboratório Zambon implantou o departamento de Trade Marketing. Entretanto decidiram encerrar as atividades desse departamento. Há 2 anos o departamento foi constituído novamente e no último ano sofreu uma reestruturação. Tosetto (2015) afirma que a estrutura ainda sofre mudanças, até encontrarem o modelo mais adequado.

O gerente comercial também é gerente de Trade Marketing. A área responde para um diretor que cuida de marketing, comercial e Trade Marketing. Assim, há um departamento de marketing separado. Esta estrutura corrobora com a literatura sobre o tema (MOTTA; SANTOS; SERRALVO, 2008, p. 103; RANDALL, 1994, p. 127; ZEYL; ZEYL, 1997, p. 177).

A vista às lojas é efetuada pelo representante que visita os médicos. Parte da responsabilidade deste profissional é voltada para Trade Marketing. No ano de 2014 a empresa contratou promotores terceirizados, mas o resultado desta equipe não foi tão bom quanto o esperado e encerraram a terceirização. Atualmente são 120 representantes que fazem a visitação a médicos e farmácias. Além disso, há um analista no departamento que cuida da parte de análise de informações e os gerentes de campo que cuidam da equipe de representantes. Os atacadistas e grandes redes são trabalhados pelo gerente de contas, que efetua a venda direta para estes canais. Entretanto este gerente de conta não faz visitação às lojas. Quem acompanha a execução das ações é o representante, que alimenta o gerente de contas com informações sobre o que está ocorrendo nos pontos de vendas.

\subsubsection{Segmentação de Canais}

No caso da Zambon, o Trade Marketing não efetua segmentação dos clientes. O Trade Marketing não separa contas especiais das demais e as ações não são focadas em um tipo de segmento, contrariando a literatura sobre o tema. 


\subsubsection{Alimentação do SIM}

Tosetto (2015) comenta que no setor farmacêutico é possível ter uma série de informações, principalmente por meio da compra de informações de empresas especializadas como IMS Health e Nielsen. O Trade Marketing do Zambon é responsável por realizar a análise de dados sobre as vendas do canal e passar a informação para o representante que visita a loja, corroborando com a literatura (KOTLER; KELLER, 2006, p. 73). Assim, quando este representante chega ao PDV, sabe quanto aquela farmácia vendeu de cada produto no ano, mês, semana e dia anterior. Com isso, ele pode, inclusive, passar esta informação para o varejista, com o objetivo de auxiliá-lo na tomada de decisões. Este fato complementa a literatura, pois não foi mencionado a possibilidade de alimentar o sistema de informação do canal. Isto ocorre porque as pesquisas são caras para farmácias de menor porte e estas acabam não as adquirindo.

O Trade Marketing ainda recebe as informações dos representantes sobre o preço praticado pelos varejistas de seus produtos e dos produtos concorrentes, indo ao encontro da literatura (ALVAREZ, 2008, p. 119; KOTLER; KELLER, 2006, p. 73). O gerente afirma que o Trade Marketing não encomenda pesquisas sobre o comportamento do shopper devido ao custo elevado de tais ações.

\subsubsection{Comportamento do Shopper}

O departamento de Trade Marketing do Zambon é responsável por solicitar, analisar e coordenar as pesquisas sobre comportamento do shopper, conforme a literatura (CÔNSOLI; D'ANDREA, 2010, p. 145) . Entretanto, devido ao alto custo, a empresa não solicita muitas pesquisas.

Tosetto (2015) enfatizou que há um grande desafio no setor farmacêutico com relação ao processo de decisão de compras. No setor farmacêutico este processo é mais complexo, pois existem diversos personagens que influenciam o comportamento de compra do shopper. O gerente ainda comenta que comparado com o setor alimentício, no qual basicamente é necessária a ativação do consumidor e do shopper, o setor farmacêutico tem diversos decisores. Ele ilustra o caso com o seguinte fato: quando uma mãe leva o filho ao médico, este médico efetua a prescrição do medicamento; o pai vai até a farmácia para efetuar a compra do 
produto; na farmácia tem a figura do farmacêutico, que pode ainda influenciar a decisão de compra. Ou seja, há muito mais decisores do que o consumidor e o shopper neste processo.

\subsubsection{Produto}

O foco maior do Trade Marketing é na linha de OTC. Como existem medicamentos $\mathrm{Rx}$, que sofrem troca e outros que não tem concorrentes, os medicamentos $\mathrm{Rx}$ da linha Zambon contemplam mais produtos sem concorrentes, pois não há genéricos e nem similares. Nestes casos, explica o gerente, a partir do momento que estes produtos são prescritos, muito provavelmente serão vendidos. Se o paciente não encontra o produto no $\mathrm{PDV}$, ele irá até outra loja, mas não trocará por outro produto.

Neste caso não há necessidade de grandes ações de Trade Marketing. O necessário é a disponibilidade do produto na farmácia. Assim, com estes tipos de medicamentos o Trade Marketing faz o gerenciamento de estoque, checando o quanto a farmácia vende de cada produto e se o estoque está adequado ou se é necessário corrigir a quantidade. Já com o OTC não há garantia de venda.

O Trade Marketing consegue influenciar o mix de produtos do cliente. Por meio de análise de dados sobre as vendas do canal, é possível orientar o varejista em relação a quantidade de produtos no mix e adequar a horizontalização e verticalização de produtos da linha. Esta atividade desempenhada está de acordo com o que foi descrito na literatura, embora o departamento não desempenhe todos as atividades relativas a produto descritas (ALVAREZ, 2008, p. 91). Os representantes ainda não alimentam a empresa com informações sobre o produto no ponto de venda, entretanto acreditam que farão isso no futuro.

\subsubsection{Preço}

O Trade Marketing participa do processo de formação de preços no fornecimento de informações. Os representantes colocam no sistema, em tempo real, qual o preço que está sendo praticado pelo varejista e o preço dos concorrentes, conforme descrito por Alvarez, 2008, p. 92). Isto permite que a empresa aumente ou diminua os preços de acordo com a estratégia para a região. 


\subsubsection{Comunicação}

A comunicação com as farmácias independentes e pequenas redes é efetuada via distribuidores. A empresa desenvolve e disponibiliza para os varejistas materiais de comunicação no PDV, conforme descrito pela literatura (CÔNSOLI; D'ANDREA, 2010, p. 162).

O representante ainda pode auxiliar no merchandising, principalmente orientando o varejista a colocar o produto da Zambon ao lado de outros produtos concorrentes, corroborando com a literatura (ALVAREZ, 2008, p. 144; MOTTA; SANTOS; SERRALVO, 2008 , p. 62). Isto ocorre para a categoria de medicamentos isentos de prescrição (MIP/OTC), pois os medicamentos de prescrição são organizados em ordem alfabética.

O varejista não faz solicitação de materiais ao laboratório. Tosetto (2015) comenta sobre a imaturidade do setor, explicando que o varejista não trabalha com estudos ou dados, como demonstrado no trecho:

“A própria loja ainda não entende e não está madura o suficiente para entender o quão é importante ela ter os materiais de comunicação adequados. Ele não sabe por exemplo o quanto ele pode aumentar o ticket médio se reter o cliente na loja. Ele não tem um estudo como "se o paciente ficar 5 minutos em média ele compra $\mathrm{x}$, se ficar 10 ele compra y". Isso ainda é muito cru nesse mercado"

Foi comentado também sobre a questão de o varejista querer sempre uma compensação para permitir que a indústria desenvolva ações na loja, o que restringe as atividades. No que diz respeito a promoção de vendas, como distribuição de brindes e amostras, Tosetto (2015) explica que como existe uma regulamentação para estas ações, realizam de forma pontual. A distribuição de amostras não é feita para o varejista, por causa da restrição legal. Já os brindes são utilizados, entretanto, sempre com o nome da empresa, nunca da marca do medicamento. Então o foco é maior em ações de cunho científico, como os treinamentos. A inserção no tabloide é bastante explorada por ser uma ação permitida pela ANVISA. O Trade Marketing é responsável por levantar a oportunidades e custos, enquanto o comercial efetua a negociação.

Outra atividade desempenhada pelo departamento de Trade Marketing é a verificação de quais feiras irão ocorrer, qual a importância da participação e qual será o custo benefício. Além disso, cabe ao Trade Marketing a decisão de participar da feira. Já a organização é efetuada pelo departamento de eventos. Esta atividade está em consonância com a literatura (FERRACCIÙ, 2007, p. 59; ROSENBLOOM, 2008, p. 315). 
As ações negociadas sobre ações de comunicação com os varejistas são efetuadas pelo gerente de contas, não sendo assim uma atribuição do Trade Marketing. A informação da negociação é passada para os representantes, os quais realizam a fiscalização nas lojas.

\subsubsection{Gerenciamento por Categorias}

A área de Trade Marketing do laboratório Zambon, até o momento, não desenvolve atividades relacionadas ao gerenciamento de categorias. Este fato é contrário ao descrito na literatura sobre o tema (ALVAREZ, 2008, p. 67).

\subsubsection{Relacionamento com o cliente}

Atualmente o relacionamento com a equipe da farmácia é visto como uma ferramenta muito importante, $\mathrm{O}$ que pode ser percebido no trecho:

\footnotetext{
"Atualmente, ao contrário das décadas de 70, 80 e começo de 90, gerar receita médica não significa vender o produto, mesmo sendo medicamento. Porque o balconista e o farmacêutico têm influência grande sobre a opção de marca ou de genérico que o paciente vai comprar. Então não basta mais ter um trabalho junto ao médico. Tem exemplo de marcas que temos um reconhecimento junto ao médico muito grande, muito maior que o concorrente $\mathrm{A} \mathrm{B}$ ou $\mathrm{C}$, mas a nossa venda não é proporcional ao que gera de prescrição. Isto ocorre porque tem um momento que o paciente está no PDV para decidir a compra dele. Hoje tão importante quanto estar no médico, ter um relacionamento com o médico e ser efetivo na visita médica é fazer a mesma coisa no PDV'(TOSETTO, 2015)
}

Como as ações da indústria farmacêutica são bem restritas em relação a comunicação, o Zambon foca em diversas ações de cunho científico e educacional. Os treinamentos são ministrados para as equipes dos varejistas, em especial as redes. Abordam temas como gripe, e não em produtos. O gerente explica que ao qualificar o profissional do varejo o paciente é melhor atendido, corroborando com a literatura (CÔNSOLI; D'ANDREA, 2010, p. 117; ROSENBLOOM, 2008, p. 312).

As demais ações de relacionamento com o canal citadas na literatura não são desenvolvidas, como participação no processo de remuneração e incentivos, principalmente por causa das restrições do setor. Os programas de suporte, compartilhamento de informações 
com o canal e uso de indicadores em conjunto também não são desenvolvidos até o momento, contrariando a literatura sobre o tema (CÔNSOLI; D’ANDREA, 2010, p. 117).

\subsubsection{Plano de Trade Marketing}

O plano da forma como é descrito por Alvarez, (2008, p. 123) para os cliente-chave ou segmentos de clientes, não é efetuado. Entretanto, há um plano de Trade Marketing que descreve o momento atual em que a marca se encontra, os objetivos e calendário de ações promocionais. Não existem planos desenvolvidos em conjunto com distribuidores ou varejistas, mas pensam em fazê-lo no futuro.

\subsubsection{Métricas de Trade Marketing}

Tosetto (2015) explica que no setor farmacêutico há uma quantidade enorme de dados, o que possibilita mensurar praticamente tudo. É possível saber para onde foi cada embalagem de medicamento, porque foi e quando foi. Tudo isso é medido o tempo todo, afirma o gerente.

A empresa acompanha o resultado de vendas, participação de mercado e rentabilidade como sugerido por Motta; Santos e Serralvo, (2008, p. 83). Também acompanha os dados de selling in e selling out comentados por Alvarez (2008, p. 136). Outros indicadores utilizados são o ROI e acompanhamento de preços praticados na ponta, comentados por Cônsoli e D'Andrea (2010, p. 234).

\subsubsection{Outras Considerações}

Um desafio comentado é a restrição em relação aos medicamentos. Além das legislações da ANVISA a multinacional segue os acordos e normas globais. Por este motivo as práticas das indústrias nacionais e multinacionais são bem diferentes. 


\subsection{Caso Biolab}

\subsubsection{Fontes de informação}

\section{Página na internet}

BIOLAB Sítio da organização. Disponível em: http://www.biolabfarma.com.br/. Acesso em: 01 de maio de 2015 (BIOLAB, 2015).

AVERT. Sítio da organização. Disponível em: http://www.avert.com.br/. Acesso em: 01 de maio de 2015.

\section{Entrevista}

Entrevista com Ana Paula Cruzato, realizada no dia 30 de abril de 2015, na matriz da Biolab, localizado na Rua Olimpíadas, 242 na cidade de São Paulo. A Sr. ${ }^{a}$ Ana Paula Cruzato é a Gerente de Trade Marketing. Atua no cargo há 4 anos. (CRUZATO, 2015)

\subsubsection{Informações gerais sobre a organização}

O laboratório Biolab foi fundado em 1997. Atualmente é uma das maiores indústrias farmacêuticas do mercado brasileiro. É uma empresa $100 \%$ nacional, focada em medicamentos inovadores. No ano de 2011, os sócios da Biolab adquiriram o laboratório Zurita. Com os produtos da Zurita criaram o laboratório Avert, aumentando, assim, o portfólio, principalmente de medicamentos OTC.

Sua linha de produtos é composta por mais de 100 itens. Diversos deles são inovadores e representam $50 \%$ do faturamento da empresa. Cerca de $10 \%$ do faturamento é destinado à pesquisa e desenvolvimento de novos produtos. A Biolab é líder no mercado brasileiro de medicamentos sob prescrição médica na área de Cardiologia. Além disso, tem produtos que atendem as áreas de Ginecologia, Dermatologia, Gastrenterologia, Reumatologia, Ortopedia, Pediatria, dentre outras (BIOLAB, 2015).

O Quadro 21 apresenta a linha de produtos do Laboratório Biolab e do laboratório Avert. 
Quadro 21 - Linha de produtos Biolab e Avert

\begin{tabular}{|c|c|}
\hline Suplementos alimentares & $\begin{array}{l}\text { Artrotabs }^{\circledR} ; \text { Disfor }^{\circledR} ; \text { Fascia }^{\circledR} ; \\
\text { Femitabs }^{\circledR} ; \text { Matertabs }^{\circledR} ; \text { Movidil }^{\circledR} ; \\
\text { Osmolac }^{\circledR} ; \text { Osseoprot }^{\circledR} ; \text { Prevelip }^{\circledR} ; \text { Relcor }^{\circledR} \\
\text { Stimulen }^{\circledR} ; \text { Vitaminerals Plus }^{\circledR}\end{array}$ \\
\hline Dermocosméticos & $\begin{array}{l}\text { Caffe Green Creme Gel Facial Noturno } \AA \text {; Caffe Green Gel Facial } \\
\text { Diurno®; Caffe Green Serum para a Área dos Olhos }{ }^{\circledR} \text {; } \\
\text { Hidrakids; M\&P Dry®; Matercare } \AA ; \text { Materskin }{ }^{\circledR} ; \text { Pantohair }{ }^{\circledR} \\
\text { Photoprot } \AA ; \\
\text { Reaox }{ }^{\circledR} ; \text { Renopel } \AA \text {; Skan; } \\
\text { Urehidra }{ }^{\circledR}\end{array}$ \\
\hline Medicamento referência & Novanlo $\AA ;$ Nebilet $\AA$; Vonau Flash $\AA ;$ Tapazol $\AA ;$ Tiamazol \\
\hline Medicamentos similares & 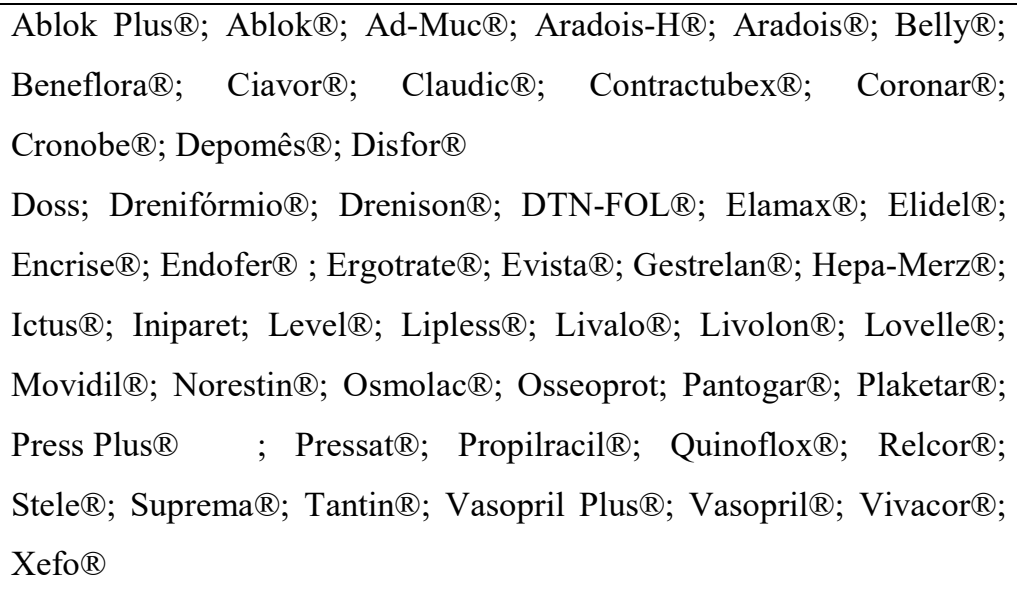 \\
\hline $\begin{array}{l}\text { Avert - Medicamentos Isentos de } \\
\text { Prescrição }\end{array}$ & Acnase ${ }^{\circledR}$, Serenus ${ }^{\circledR}$, Sinustrat ${ }^{\circledR}$, Novarrutina ${ }^{\circledR}$, Laxette $\AA$ \\
\hline
\end{tabular}

Fonte: elaborado pela autora com base em Biolab, 2015

\subsubsection{Descrição do caso}

\subsubsection{Estrutura Organizacional}

Há um departamento específico na Biolab de Trade Marketing, que foi constituído recentemente, há cerca de 4 anos. O departamento é composto apenas pela gerente de Trade Marketing. Está subordinado ao departamento comercial, à gerência nacional de vendas e vice-presidência comercial. Este fato corrobora com a literatura que afirma que o Trade 
Marketing pode estar subordinado ao departamento comercial (ALVAREZ, 2008, p. 97; MOTTA; SANTOS; SERRALVO, 2008, p. 103; RANDALL, 1994, p. 127)

Com a compra do laboratório Zurita, a Biolab aumentou sua linha OTC. Com isso, o Trade Marketing ganhou uma verba própria. Ainda não há uma equipe de campo de promotores de venda. Entretanto, a empresa pretende nos próximos anos implantar uma força com promotores. Atualmente o trabalho de visitas ao PDV é efetuado pelos propagandistas, que visitam os médicos e os PDV. Esta equipe está subordinada ao departamento comercial.

\subsubsection{Segmentação dos canais de distribuição}

O laboratório Biolab efetua a segmentação dos canais pelo volume de compras, corroborando com a literatura sobre o tema (ALVAREZ, 2008, p. 104; CÔNSOLI; D'ANDREA, 2010, p. 128). Outra forma de segmentação utilizada é por meio da organização da empresa como atacadistas, grandes redes e farmácias independentes. A ação citada para as contas especiais foi relativa a ações comerciais como descontos.

\subsubsection{Sistema de Informação de Trade Marketing}

As atividades referentes ao sistema de informação de Trade Marketing na Biolab são principalmente a coleta de informações do ponto de venda sobre preços e ações dos concorrentes, como descrito por Kotler; Keller, (2006, p. 73). Há um treinamento formal e a coleta é contínua e sistemática como sugerido por Alvarez (2008, p. 119). Também são analisados dados de fornecedores externos como Nielsen e IMS Health descrito por Kotler e Keller (2006, p. 73).

Além disso, a empresa compartilha informações com os clientes. Algumas informações são sigilosas e por isso não são compartilhadas. Entretanto dados sobre participação de mercado, ranking e faturamento de produtos são transmitidas ao cliente. Não foram encontradas descrições sobre esse tipo de ação na literatura. 


\subsubsection{Comportamento do Shopper}

Para a gerente de Trade Marketing da Biolab, o foco deve ser o consumidor, pois as empresas estão muito focadas no que elas ganham, mas não no que o consumidor ganhará. $\mathrm{O}$ Trade Marketing é um consultor do consumidor final, ele tem que disponibilizar o produto da melhor forma, com melhor preço e entregar um pacote pronto. Entretanto, para o produto chegar no consumidor existe um intermediário. Neste caso, o Trade Marketing também é um viabilizador dos negócios para o consumidor. Esta visão corrobora com a apresentada por Cônsoli e D'Andrea (2010, p. 128)

O departamento é responsável por efetuar e analisar as pesquisas de comportamento do shopper. Essa atividade vai ao encontro do que foi descrito na literatura (CÔNSOLI; D'ANDREA, 2010, p. 144).

\subsubsection{Produto}

Em relação à influência do Trade Marketing no mix de produtos do varejista, o foco da empresa é garantir que haja o produto no PDV. Principalmente para que a prescrição seja atendida. Assim, o trabalho é focado em farmácias próximas a médicos que prescrevem os produtos. Além disso, o departamento adequa o volume de demanda ao PDV. Cruzato (2015) afirma que o Trade Marketing somente pode influenciar o mix de produtos do varejista se tiver conhecimento do mercado. O trecho abaixo ilustra a preocupação em adequar o mix de produtos aos clientes:

"Você tem que saber eleger o PDV certo para cada produto. Isto porque o meu mix é muito grande eu nem sempre vou ter disponibilizado de forma horizontalizada para toda a cadeia varejista. Então consegue sim influenciar desde que você tenha respaldo e tenha respeito pelo perfil do varejo e perfil do consumidor. Para você disponibilizar um produto que não terá giro só por vender já começa errado ação do trade".

Em relação a embalagens, os representantes, além de trazer informações sobre a performance da embalagem na gôndola, também têm autonomia para a compra de produtos cujas embalagens estão com a aparência ruim, sendo reembolsados depois. Este caso corrobora com a literatura em relação à atratividade de embalagens (ALVAREZ, 2008, p. 91) e ainda contribui com a visão de que o Trade Marketing deve preocupar-se com a presença de produtos com embalagens danificadas no ponto de venda. 
Um desafio colocado foi em relação ao mix de produtos do varejista, tanto no caso de ruptura quanto no de produto errado no mix, como é exposto na narrativa:

"O produto errado alocado em loja errada é o maior problema. Às vezes vejo produtos de valor agregado altíssimo alocado em lojas de periferia. Como é que você tem 10 produtos de uma caixa que custa 120 reais em uma loja da periferia e uma loja que é perfil, que tem um público consumidor não? $\mathrm{O}$ trade tenta disponibilizar da melhor forma possível para o consumidor final, tem que conhecer o perfil do consumidor, naquele lugar, naquela região. "(CRUZATO, 2015)

\subsubsection{Preço}

Os representantes têm a cultura de trazer informações do PDV para a empresa. Geralmente são informações relativas a ações da concorrência e preço de produtos. Em relação ao preço, o Trade Marketing não tem grande influência. $\mathrm{O}$ departamento comercial que é encarregado de definir os descontos e conversar com o cliente caso o preço do produto esteja elevado. Nesta situação, o Trade Marketing atua munindo o departamento comercial de informações sobre o preço, sendo as ações parcialmente relacionadas as descritas na literatura (ALVAREZ, 2008, p. 92; CÔNSOLI; D’ANDREA, 2010, p. 136).

\subsubsection{Comunicação}

A Biolab sempre possuiu uma cultura de comunicação muito focada na propaganda médica. Assim, nota-se um receio em relação às ações de comunicação no ponto de venda. Entretanto, é uma preocupação atual da empresa a troca de marcas de medicamentos que pode ser efetuada na farmácia, assim como a má exposição do produto no ponto de venda.

O departamento também é responsável pela elaboração de materiais de comunicação no PDV, como descrito pela literatura (CÔNSOLI; D'ANDREA, 2010, p. 162). Entretanto, nota-se novamente uma preocupação em relação a algumas categorias como dermocosméticos. Cruzato (2015) explica que os materiais para esta categoria não devem chamar muita atenção para que não exista a percepção de que o consumidor e o varejista são mais importantes que o médico. Há uma tentativa de customizar o material de PDV para os diferentes tipos de lojas. Isto evita que materiais fiquem parados em estoque ou até na casa do representante.

Quando o varejista permite, os representantes trabalham a exposição do produto, estando, assim, em consonância com a literatura (ALVAREZ, 2008, p. 144; MOTTA; 
SANTOS; SERRALVO, 2008, p. 62). Podem também orientar o varejista ou alterar a exposição, conforme o planograma desenvolvido pela Biolab.

A inserção em tabloides são ações pontuais, entretanto executadas com a participação do Trade Marketing. É utilizada para alteração de preços quando o valor está muito alto ou como ferramenta de troca. É visto como uma ajuda para sell in e não para sell out. Dessa forma, esta atividade vai ao encontro do que foi descrito na literatura (MOTTA; SANTOS; SERRALVO, 2008, p. 62; ROSENBLOOM，2008， p. 306; ROSLOW; LASKEY; NICHOLLS, 1993).

A participação da Biolab em feiras e eventos para o canal é recente e ainda pequena. $\mathrm{O}$ maior foco são os eventos médicos, que embora não tem participação do departamento de Trade Marketing. No caso das feiras para os canais, o departamento de Trade Marketing decide quais feiras a empresa irá participar e efetua a organização em conjunto com o departamento de eventos, corroborando com a literatura (FERRACCIÙ, 2007, p. 59; ROSENBLOOM, 2008, p. 315).

A negociação de ações no PDV, como montagem de kits, leve 3 pague 2 e pontas de gôndola, é efetuada pelo Trade Marketing. Entretanto, estas ações não são negociadas em grandes redes, pois não há equipe para fiscalizá-las. Em redes menores, o vendedor visita as lojas e realiza a fiscalização destas ações. O trecho abaixo ilustra esta passagem.

"Como não temos uma equipe de promotores iriamos rasgar dinheiro. É mais uma coisa que eu falo a indústria abraçou como responsabilidade quando tem que ser compartilhado é negócio para os dois lados. " (CRUZATO, 2015)

Ainda em relação à negociação de espaços, a gerente da Biolab faz a seguinte reflexão:

“O varejo está virando locação de espaço ou é um prestador de serviços para o consumidor final?"

\subsubsection{Gerenciamento de Categorias}

A Biolab também atua pouco com o gerenciamento de categorias. Esta atividade está mais focada na categoria de dermocosméticos. A gerente explica que auxiliam o varejista com relação ao gerenciamento dos dermocosméticos, mas quem detém mais conhecimento sobre estes produtos são as empresas multinacionais que atuam com esta linha. Desenvolvem também o planograma para a categoria, corroborando com a literatura (ALVAREZ, 2008, p. 67). 


\subsubsection{Relacionamento com o cliente}

Hoje, a empresa se preocupa em falar com os farmacêuticos. Antes a empresa não via essa necessidade, pois acreditava que o receituário bastava. Atualmente, dependendo da linha, é necessário que a cadeia inteira esteja informada sobre o produto e quais são seus diferenciais. Assim, quando chega uma prescrição, estão conscientes que aquele produto não pode ser trocado.

Há treinamentos presenciais que são oferecidos para a equipe do varejista, como balconistas, farmacêuticos e gerência. Os temas podem ser técnicos ou focados em outros temas de interesse. A responsabilidade de organização destes treinamentos é do departamento de Trade Marketing. Esta atividade está de acordo com o que foi descrito na teoria sobre o assunto (CÔNSOLI; D'ANDREA, 2010, p. 117; ROSENBLOOM, 2008, p. 312). Ainda não há um portal online, entretanto, a empresa pensa em fazê-lo no futuro.

Em relação a incentivos para a equipe do canal, as ações em dinheiro são ilegais e algumas ações não são aprovadas pelo compliance. A troca de informações com os principais clientes gira em torno de participação de mercado e faturamento dos produtos. Existem algumas informações que são sigilosas e, portanto, não são transmitidasaos membros do canal. Ainda não são utilizados indicadores em conjunto. Esta descrição contraria a literatura sobre as demais atividades realizadas pelo departamento de Trade Marketing (CÔNSOLI; D'ANDREA, 2010, p. 117)

\subsubsection{Plano de Trade Marketing}

O Trade Marketing da Biolab é responsável pela elaboração de um plano anual. Este plano pode ser alterado caso haja necessidade. É elaborado em meados de outubro, pois é utilizado para buscar a negociação de ações junto aos varejistas e a programação da verba do departamento junto a empresa no início do ano.

O plano também é desenvolvido em conjunto com os canais de distribuição para verificar qual a disponibilidade do cliente para cada ação. Esse fato corrobora com o descrito por Shankar et al., (2011). 


\subsubsection{Métricas de Trade Marketing}

Na Biolab, o Trade Marketing procura mensurar as ações efetuadas. São acompanhados o selling in e o selling out, corroborando com Alvarez, (2008, p. 136). A gerente explica que é importante que o Trade Marketing acompanhe estes dois indicadores, pois por meio deles é possível mediar as ações do departamento comercial que está preocupado com o selling in e o marketing que se preocupa com o selling out. Dessa forma, o Trade Marketing promove um equilíbrio entre a venda e imagem da marca.

A Biolab preocupa-se com a satisfação do consumidor. Entretanto não consegue mensurar isso. Outra preocupação é quanto ao retorno de negociações de espaços no varejo. Já que não é possível mensurar o retorno, fazem estas ações com bastante cautela.

A empresa ainda acompanha o resultado de vendas, participação de mercado e rentabilidade como sugerido na literatura (MOTTA; SANTOS; SERRALVO, 2008, p. 83). Outros indicadores utilizados são o ROI e acompanhamento de preços praticados na ponta, comentados por Cônsoli e D’Andrea (2010, p. 234).

\subsubsection{Outras considerações}

O Trade Marketing é responsável por todas as linhas de produto da empresa, embora os dermoscosméticos sejam pouco trabalhados pelo Trade Marketing. A cultura principal da empresa é o investimento em propaganda médica. Por isso, uma preocupação muito grande em relação ao conflito entre o trabalho no PDV com a propaganda médica: a ameaça está na possibilidade dos médicos pararem de prescrever seus produtos porque a empresa está fazendo ações junto à farmácia. O conceito de Trade Marketing, de modo geral, é visto pela empresa como um consultor do consumidor final e que usa o canal para facilitar a vida deste consumidor. $\mathrm{O}$ ideal é que o intermediário, a indústria e o consumidor sejam beneficiados. 


\subsection{Caso Sandoz}

\subsubsection{Fontes de Informação}

\section{Página na internet}

SANDOZ. Sítio da organização no Brasil. Disponível em:

http://www.sandoz.com.br/index.shtml. Acesso em: 23 de maio de 2015 (SANDOZ, 2015a).

SANDOZ. Sítio global da organização. Disponível em: http://www.sandoz.com Acesso em: 23 de maio de 2015 (SANDOZ, 2015b).

SANDOZ. Sítio da Universidade Sandoz. Disponível em: http://www.unisandoz.com.br/login/index.php Acesso em: 21 de maio de 2015 (SANDOZ, 2015c).

NOVARTIS. Sítio Novartis no Brasil. Disponível em: http://www.novartis.com.br/ Acesso em: 21 de maio de 2015 (NOVARTIS, 2015).

\section{Entrevista}

Entrevista com a Flávia Osaki, realizada no dia 19 de maio de 2015, na sede do Grupo Novartis, localizado na Rua Vicente Rao, 90, na cidade de São Paulo. A Flávia Osaki é a Gerente de Trade Marketing da área Distribuidores do Laboratório Sandoz. Atua no cargo há 2 anos. Anteriormente trabalhava na Sandoz na área de negócios comerciais (OSAKI, 2015).

\subsubsection{Informações gerais sobre a organização}

A Sandoz nasceu no ano de 1886 na cidade de Basiléia, na Suíça. No ano de 1996, a Sandoz e o laboratório Ciba-Geigy se integram e formam o Grupo Novartis. Em 2003, o Grupo Novartis unifica todas as unidades de medicamentos genéricos na marca Sandoz. Atualmente, a empresa está presente em 140 países (NOVARTIS, 2015; SANDOZ, 2015a, 2015b). No mercado global a Sandoz é a segunda maior fabricante de medicamentos genéricos. Entretanto, no mercado brasileiro a empresa não consta no ranking das maiores. 
Seu portfólio de produtos contempla cerca de 99 moléculas que incluem medicamentos para o tratamento de doenças do sistema nervoso central, distúrbios do aparelho digestivo, tratamentos cardiovasculares e terapias hormonais. A linha de produtos da Sandoz compreende medicamentos genéricos, medicamentos de marca, medicamentos biológicos e medicamentos oncológicos.

O Quadro 22 apresenta a linha de medicamentos genéricos e similares equivalentes do laboratório Sandoz.

\section{Quadro 22 - Linha de produtos Sandoz}



Fonte: elaborado pela autora com base em Sandoz, 2015a 


\subsubsection{Descrição do caso}

\subsubsection{Estrutura Organizacional}

Na Sandoz há um departamento de Trade Marketing desde 2008. É responsável tanto pela linha de medicamentos genéricos quanto pela linha de medicamentos similares. A Sandoz ainda possui uma linha de medicamentos oncológicos, os quais são de uso restrito a hospitais e por isso a linha não é passível de ações do Trade Marketing. A área está subordinada à diretoria comercial, corroborando com a literatura sobre a estrutura de Trade Marketing (ALVAREZ, 2008, p. 97; MOTTA; SANTOS; SERRALVO, 2008, p. 103; RANDALL, 1994, p. 126)

Nos últimos dois anos o departamento passou por uma reestruturação. Houve uma divisão da área segundo os canais atendidos. Assim, o Trade Marketing da Sandoz na configuração atual é dividido em Trade Redes e Trade Distribuidores. O Trade Redes atende a grandes redes de farmácia. Já o Trade Distribuidor é responsável pelos atacadistas, farmácias independentes, redes médias, pequenas e associativistas. Cada uma destas áreas possui um gerente de Trade Marketing, um analista e um estagiário. A área de Trade Redes tem promotores de vendas que efetuam a visitação das farmácias. A área Trade Distribuidores trabalha em parceria com os gerentes de conta e representantes de vendas. Os representantes de vendas atendem em torno de 16.000 farmácias e estão subordinados ao departamento comercial.

Segundo Osaki (2015) o Trade Marketing é uma função que está evoluindo e ganhando espaço. No passado, as empresas não cuidavam dessa área e o mercado não entendia o seu papel. Ultimamente esta atividade está sendo reconhecida e adquirindo mais importância. O Trade Marketing é entendido como uma ponte entre o departamento comercial e o departamento de marketing, juntando as metas do departamento comercial com as estratégias de marketing. Além disso, o Trade Marketing verifica as necessidades do canal, assim como a atuação dos concorrentes e market share no PDV. Esta visão está em consonância com a apresentada por Alvarez, (1999) sobre o Trade Marketing como uma função que integra o departamento de vendas e o departamento de marketing. 


\subsubsection{Segmentação dos canais de distribuição}

A segmentação do canal de distribuição na Sandoz é uma atividade desenvolvida pelo departamento de Trade Marketing. É feita pela categorização de canais conforme a importância em relação ao faturamento e à influência do canal na região. Além disso, o departamento também cria estratégias para cada segmento de interesse. Neste caso a segmentação de canais corrobora com a literatura sobre o tema (ALVAREZ, 2008, p. 104; CÔNSOLI; D’ANDREA, 2010, p. 128)

\subsubsection{Sistema de Informação de Trade Marketing}

Na Sandoz os representantes são treinados a transmitirem sempre informações sobre o que está acontecendo no PDV, como por exemplo, ações da concorrência como utilização de brindes e descontos mais agressivos. Têm um relacionamento direto com o Trade Marketing ganhando mais agilidade para obtenção de informações, explica a gerente. Enquanto esta informação é transmitida no momento em que está ocorrendo, a análise de dados do IMS Health somente serão vistos um ou dois meses depois. Nas reuniões que são feitas com os representantes é explicado que eles são os olhos da empresa no PDV. Há um sistema interno, que é alimentado pelo representante com estes dados.

Além disso, o representante leva informações aos varejistas, principalmente para o pequeno, que não tem acesso as pesquisas. Outro ponto trabalhado pelo Trade Marketing é a encomenda de pesquisas. Estas pesquisas são focadas no comportamento do shopper e o comportamento do canal de distribuição. A Sandoz trabalha em todos os pontos descritos por (KOTLER; KELLER, 2006, p. 73), pesquisa, registros internos e inteligência. O trabalho de campo, principalmente do gerente de Trade Marketing, é intenso.

\subsubsection{Comportamento do Shopper}

O departamento de Trade Marketing da Sandoz é responsável pela pesquisa e análise do comportamento do shopper. Foi comentado que recentemente encomendaram uma pesquisa ao IMS Health sobre o comportamento do shopper, utilizando grupo focal. O departamento fez a análise da pesquisa e a distribuição das informações para os departamentos de comunicação, marketing e comercial. Sendo assim, é desenvolvido a 
atividade de pesquisa de Trade Marketing descrita pela literatura (CÔNSOLI; D'ANDREA, 2010, p. 144).

\subsubsection{Produto}

A Sandoz somente fornece seus produtos para distribuidores mediante um contrato que contemple uma cláusula sobre a aquisição da linha completa. Além disso, há uma política global da Novartis que não permite que os canais tenham mais de 90 dias de um produto em estoque. Uma das explicações para isso é não sobrecarregar o estoque de um cliente, pois isso pode ocasionar danos à saúde financeira dele. Assim, a compra deste produto fica bloqueada para o cliente.

Uma vez por mês é realizada uma reunião com todos os clientes na qual é discutido o mapa de demanda e de estoque. Esta informação é cruzada com o relatório do IMS Health para verificar se há divergências. Isso incentiva os gerentes de contas a trabalhar o mix de produto de uma forma saudável.

Osaki (2015) também comenta que o departamento de Trade Marketing pode influenciar o desenvolvimento de novos produtos. Neste caso há uma parceria com o departamento de marketing para verificar a possibilidade do desenvolvimento de um novo produto. Em seu lançamento, pode ocorrer um evento em que clientes chave são convidados. Este evento é responsabilidade do departamento de marketing com a participação do departamento de Trade Marketing. Isso é evidenciado no depoimento:

"No começo de dezembro tivemos um lançamento e trouxemos todos os nossos principais clientes para dentro da Novartis, no nosso auditório. Foi feita a apresentação do produto pelo nosso presidente e o presidente da américa Latina da Sandoz veio para esse evento. Nós reunimos nesse dia os maiores distribuidores e muitas redes. "(OSAKI, 2015).

As atividades desempenhadas em relação a produtos corroboram em partes com a literatura. Neste caso não foram verificados coleta de informações sobre os produtos de concorrentes e atratividade de embalagens (ALVAREZ, 2008, p. 91).

\subsubsection{Preço}

A formação de preço é um trabalho em conjunto entre os departamentos de marketing, comercial, Trade Marketing e finanças. O Trade Marketing envia uma proposta de preços, 
considerando as ações do concorrente e qual o preço que deve ser adotado para que o produto seja competitivo. Essa proposta é analisada pelo departamento de finanças para calcular a viabilidade. Em relação ao preço, a decisão final é do departamento de finanças. A participação do Trade Marketing na formação de preços corrobora com o apresentado por (CÔNSOLI; D'ANDREA, 2010, p. 136).

Osaki (2015) ainda explica que os representantes são responsáveis por acompanhar os preços praticados pelo varejista, tanto da empresa quanto dos concorrentes. Além disso, o Trade Marketing orienta os canais sobre o preço quando está acima ou abaixo da faixa pretendida pela empresa, evitando o conflito entre os canais.

\subsubsection{Comunicação}

O departamento de Trade Marketing da Sandoz desenvolve materiais de comunicação no PDV como descrito na teoria (CÔNSOLI; D'ANDREA, 2010, p. 162). Entretanto, Osaki (2015) explica que a verba para esta ação é limitada. A quantidade de materiais disponibilizados pela empresa é menor, em relação aos concorrentes.

De acordo com a política da Novartis, as promoções de vendas podem ser efetuadas para os canais de distribuição, estando em conformidade com a literatura (ALVAREZ, 2008, p. 144; MOTTA; SANTOS; SERRALVO, 2008, p. 62). Entretanto estas ações devem seguir algumas normas da empresa: para a distribuição de brindes, o item deve ter relação com a atividade do canal; e a marca nunca pode ser associada a bebidas alcoólicas, em qualquer outra ação de comunicação.

A exposição do produto é considerada muito importante e o representante se preocupa com a forma como o produto está sendo exposto. Principalmente na linha de genéricos, a exposição é essencial. Para isso, o representante recebe um treinamento sobre a exposição do produto. $\mathrm{O}$ relacionamento do representante com a equipe da farmácia pode colaborar para que o representante tenha permissão para alterar a exposição dos medicamentos. Há uma ação interna na qual os representantes mandam fotos de paredões de produtos da marca que conquistaram por meio de relacionamento com a equipe da farmácia. Estas fotos são divulgadas na intranet da empresa e no jornal interno. Dessa forma, a empresa desenvolve ações de merchandising descrita na literatura (ALVAREZ, 2008, p. 144; MOTTA; SANTOS; SERRALVO, 2008, p. 62).

O Trade Marketing também é responsável pela inserção no tabloide do varejista, conforme a teoria (MOTTA; SANTOS; SERRALVO, 2008, p. 62; ROSENBLOOM, 2008, p. 
306; ROSLOW; LASKEY; NICHOLLS, 1993). Osaki (2015) afirma que, como a linha de OTC da empresa é muito pequena, geralmente a inserção é mais institucional.

Ainda em relação à comunicação, foi comentado que há um conflito entre os interesses da indústria e do varejista, exemplificado no trecho abaixo:

"Nós queremos fazer o nosso paredão para a marca ficar visível para o consumidor, eles (os varejistas) querem algo que vai diminuir o custo deles, como sacolinha, bobina para a maquininha de cupom fiscal...”

O departamento de Trade Marketing da Sandoz também é responsável pelas feiras e eventos, que podem ser tanto os eventos de cunho institucional quanto de vendas, como feiras de negócios organizadas pelos parceiros. Não somente fica a cargo do Trade Marketing a organização do evento, mas também de criar estratégias para atingir as metas de retorno do investimento efetuado. Sendo assim, a ação vai ao encontro do que foi levantado na literatura (FERRACCIÙ, 2007, p. 59; ROSENBLOOM, 2008, p. 315).

As negociações de ações no ponto de venda e tabloide são efetuadas pelo gerente de contas e pelos representantes de vendas, com suporte do departamento de Trade Marketing. O compliance limita alguns tipos de ações. Ao mesmo tempo, principalmente por causa do compliance, as ações negociadas necessitam ser fiscalizadas, pois é preciso a comprovação e prestação de contas.

\subsubsection{Gerenciamento de Categorias}

O Trade Marketing da Sandoz tenta realizar atividades relacionadas a gerenciamento de categorias, corroborando com a literatura (ALVAREZ, 2008, p. 67). Entretanto a gerente explica que, muitas vezes, auxiliar no gerenciamento de categorias é ensinar para o varejista o que é gerenciamento de categorias. Dessa forma o representante atua também treinando o varejista sobre esse tema.

\subsubsection{Relacionamento com o cliente}

$\mathrm{Na}$ Sandoz há uma área de treinamentos na empresa que se reporta para a mesma diretoria que o departamento de Trade Marketing. Os treinamentos são desenvolvidos na 
chamada Universidade Sandoz. Trata-se de um ambiente online que tem treinamentos para a equipe de vendas da própria Sandoz, para distribuidores e para balconistas.

Todos os temas são padronizados. Os treinamentos sempre devem ter relação com medicamentos, estipulado pelo compliance da empresa. Há um comitê que aprova os cursos disponibilizados. São temas técnicos que contemplam: disfunção erétil, sistema digestivo; sistema cardiovascular, sistema nervoso central, dor e infecções. Ainda neste portal há um tópico sobre notícias do laboratório e um "fale conosco", que possibilita a comunicação com o laboratório. Este fato concorda com o que foi encontrado na literatura visita (CÔNSOLI; D'ANDREA, 2010, p. 117; ROSENBLOOM, 2008, p. 312).

Não há participação no processo de remuneração ou incentivo a equipe do canal. Tanto pelas políticas da empresa quanto pela legislação, não é possível efetuar este tipo de ação. Sendo assim, é contrário ao descrito na literatura (CÔNSOLI; D’ANDREA, 2010, p. 117).

Há um forte compartilhamento de informações com o canal, confirmando os achados na teoria visitada (CÔNSOLI; D'ANDREA, 2010, p. 117). Nas reuniões periódicas realizadas há uma parceria com o membro do canal, discutindo-se quais são as formas de crescimento para os dois lados. Os números são analisados em conjunto e a resolução dos problemas também. As metas por clientes são comparadas com os dados do IMS Health.

Além disso. Osaki (2015) afirma que estão preparando a equipe de representantes para atuar de forma consultiva para o distribuidor e varejista e, assim, não ser um simples tirador de pedido. A ideia é que o representante seja também um consultor, levando informações, principalmente para o pequeno varejista. Outro ponto é ajudar o varejista a fazer o cálculo de rentabilidade e explicar a curva $\mathrm{ABC}$ de produto, pois o varejista não conhece estes conceitos e não os aplica, exemplifica Osaki (2015). Os representantes são, portanto, treinados para serem multiplicadores dessas informações no ponto de venda. Este fato corrobora com o programa de suporte para melhorias nas operações do canal, citado por Cônsoli; D'Andrea, (2010, p. 117).

\subsubsection{Plano de Trade Marketing}

O plano de Trade Marketing está contido no plano de marketing. Anualmente os departamentos desenvolvem este plano conjuntamente. Em julho, inicia-se o desenvolvimento doo plano para o ano seguinte. 
Na parte de Trade Marketing são especificadas as ações em cada tipo de canal. O plano é apresentado regional e globalmente. Há um compartilhamento de plano com os principais clientes e estes clientes também partilham seus planos.

$\mathrm{O}$ orçamento de Trade Marketing é separado, inclusive pelas áreas Trade Redes e Trade Distribuidores. As atividades de plano de trade marketing realizadas pela Sandoz estão em consonância com a literatura levantada (ALVAREZ, 2008, p. 123; SHANKAR et al., 2011).

\subsubsection{Métricas de Trade Marketing}

As políticas de compliance da Novartis determinam que todas as ações efetuadas precisam ser comprovadas e, na medida do possível, o retorno obtido deve ser mensurado. A mensuração de resultados é efetuada para algumas ações e outras não, pois nem todas as ações podem ser mensuradas. Um exemplo que foi dado é a inserção da marca em um tabloide. A gerente afirma que como a divulgação é institucional não há como medir o retorno gerado.

Já ações como a participação em feiras de negócios, é possível mensurar por meio do volume de vendas efetuado durante o evento. O indicador mais utilizado é o Return on Investment (ROI), comentado por Cônsoli e D'Andrea, (2010, p. 234).

Além disso, a empresa acompanha o resultado de vendas, participação de mercado e rentabilidade como sugerido por Motta; Santos e Serralvo (2008, p. 83). Também acompanha os dados de selling in e selling out para avaliar a performance obtida no cliente, comentados por Alvarez (2008, p. 136).

\subsubsection{Outras Considerações}

Todas as ações efetuadas devem ser desenvolvidas em consonância com o compliance da Novartis. Há normas de conduta que a empresa acredita ser as mais corretas e mais éticas. A entrevistada citou como desafio a concorrência com outras indústrias que praticam preços muito inferiores e a preocupação em relação a qualidade, pois o consumidor ainda não tem maturidade para entender a relação entre preço e qualidade do medicamento. O consumidor também acredita que medicamentos genéricos são todos iguais. Já os profisssionais que trabalham nas farmácias são mais preocupados com a qualidade da marca do genérico. 
A decisão de compra é do balconista na maioria dos casos, principalmente em relação ao medicamento genérico: de acordo uma pesquisa encomendada pela empresa Sandoz, os consumidores afirmam que acatam o que o balconista sugere. Este também é um dos motivos pelo qual o Trade Marketing vem crescendo na empresa.

\subsection{Análise consolidada dos casos}

A análise dos casos foi efetuada de acordo com as categorias estabelecidas no referencial teórico e utilizadas na análise individual dos casos. As categorias são: estrutura, segmentação dos canais de distribuição, sistema de informação de Trade Marketing, comportamento do shopper, produto, preço, comunicação, gerenciamento de categorias, relacionamento com o canal de distribuição, plano de Trade Marketing e métricas de Trade Marketing.

\subsubsection{Estrutura}

Todos os departamentos de Trade Marketing estudados foram criados recentemente, sendo o mais antigo o do laboratório Sandoz, com 7 anos de existência. Outro ponto interessante é que as estruturas mais robustas pertencem aos laboratórios que trabalham com medicamentos genéricos, como é o caso da Sandoz e da EMS. Uma possível explicação para este fato é baseada no histórico dos medicamentos.

Antes da entrada dos medicamentos genéricos no mercado, a troca de receituário não era permitida. Assim, a indústria farmacêutica focou seus esforços na propaganda médica, pois a decisão de compra era do médico. Quando ocorre a regulamentação dos medicamentos genéricos, os laboratórios produtores desta categoria perceberam que era necessário um trabalho no ponto de venda para incentivar a troca do medicamento referência pelo genérico. Após algum tempo, o referência acaba perdeu mercado para o genérico e foram iniciadas ações no ponto de venda para evitar a troca. Com a normatização dos equivalentes a concorrência aumenta. Neste momento a decisão do fármaco ainda é do médico, entretanto a decisão da marca é da equipe da farmácia. Por esse motivo, o Trade Marketing torna-se mais importante no setor farmacêutico, em especial para os medicamentos que sofrem mais concorrência na farmácia. 
Na EMS o departamento de Trade Marketing da divisão EMS Genéricos é mais estruturado e desenvolve mais atividades. Por este motivo é utilizado como um modelo para a divisão EMS Marcas. Há uma grande diferença na estrutura das divisões em termos de tamanho. Nota-se também que todos os laboratórios afirmaram que passaram por reestruturações no Trade Marketing nos últimos 2 anos. O Trade Marketing está subordinado em alguns laboratórios ao marketing e em outros ao departamento comercial, corroborando com a literatura (MOTTA; SANTOS; SERRALVO, 2008, p. 103; RANDALL, 1994, p. 112; ZEYL; ZEYL, 1997, p. 177). A organização dos departamentos tem um quadro muito enxuto e somente o laboratório Sandoz tem uma estrutura segmentada por canal de distribuição, conforme sugerido por Cônsoli e D'Andrea (2010, p. 157).

Em relação ao promotor de vendas pode-se perceber que pode ser efetivamente um promotor ou o representante de vendas é quem exerce essa função de promotor. Pode ainda ser o propagandista médico quem faz também a função de promotor, sendo esta uma peculiaridade do setor. No setor farmacêutico, diferentemente do setor alimentício, o promotor não efetua reposição de mercadoria e não estão a disposição do varejista, apenas fazem visitas.

Os achados em relação a estrutura de Trade Marketing nos casos estudados estão relacionados na Tabela 2 .

Tabela 2 - Relação entre os principais temas de estruturas e casos estudados.

\begin{tabular}{|c|c|c|c|c|c|c|}
\hline & \multicolumn{2}{|l|}{ EMS } & \multirow[t]{2}{*}{ Zambon } & \multirow[t]{2}{*}{ Biolab } & \multirow[t]{2}{*}{ Sandoz } & \\
\hline & Marcas & Genérico & & & & \\
\hline $\begin{array}{l}\text { Departamento } \\
\text { específico }\end{array}$ & Não & Sim & Não & Sim & Sim & \\
\hline $\begin{array}{l}\text { Tempo de } \\
\text { existência }\end{array}$ & 4 anos & 5 anos & 2 anos & 2 anos & 7 anos & \\
\hline Subordinado à & $\begin{array}{l}\text { Gerência de } \\
\text { marketing }\end{array}$ & $\begin{array}{l}\text { Diretoria } \\
\text { de } \\
\text { marketing }\end{array}$ & Diretoria & $\begin{array}{l}\text { Gerência Naciona } \\
\text { de Vendas }\end{array}$ & $\begin{array}{l}\text { Diretoria } \\
\text { comercial }\end{array}$ & \\
\hline Canais que atende & Varejistas & $\begin{array}{l}\text { Distribui- } \\
\text { dores e } \\
\text { varejistas }\end{array}$ & Varejistas & $\begin{array}{l}\text { Distribuidores } \\
\text { varejistas }\end{array}$ & $\begin{array}{l}\text { Distribuidores } \\
\text { varejistas }\end{array}$ & $\mathrm{e}$ \\
\hline $\begin{array}{l}\text { Quem exerce a } \\
\text { função } \\
\text { promotor é }\end{array}$ & Promotor & Vendedor & $\begin{array}{l}\text { Propagandista } \\
\text { e vendedor }\end{array}$ & $\begin{array}{l}\text { Propagandista } \\
\text { vendedor }\end{array}$ & $\begin{array}{l}\text { Vendedor } \\
\text { promotor, }\end{array}$ & $\mathrm{e}$ \\
\hline
\end{tabular}

Fonte: elaborada pela autora.

De acordo com Alvarez, (2008, p. 82) o processo de implantação do Trade Marketing pode ocorrer em cinco fases. Nota-se que as empresas estudadas estão em diferentes fases de implantação. Podemos classificar o Zambon como fase de vendas, a EMS Marcas como fase de marketing, Biolab na fase cliente, EMS Genéricos na fase resultado financeiro e Sandoz na 
fase desenvolvimento de negócios. A Figura 17 apresenta a evolução das fases de implantação do Trade Marketing, além do nível em que as empresas estudadas encontram-se.

Figura 17 - Evolução das fases de implantação do Trade Marketing

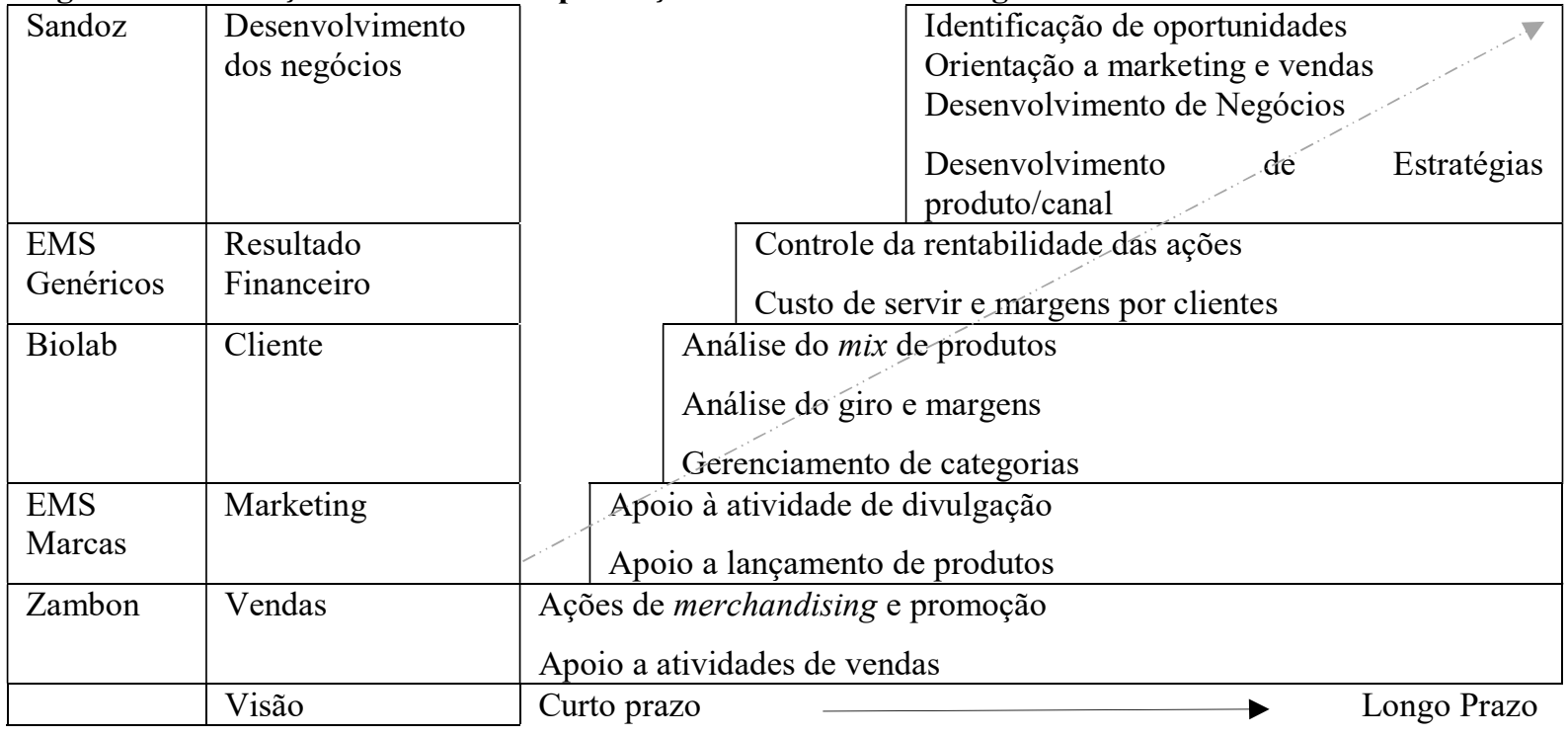

Fonte: adaptado de Alvarez (2008, p. 84)

\subsubsection{Segmentação dos canais de distribuição}

No caso do setor farmacêutico a segmentação dos canais de distribuição é restrita a atacadistas de medicamentos e drogarias, uma vez que os medicamentos no Brasil somente podem ser distribuídos nestes canais. Grande parte dos casos estudados efetua a segmentação de canais como proposto pela literatura (ALVAREZ, 2008, p. 104; CÔNSOLI; D'ANDREA, 2010, p. 128). Entretanto, as ações diferenciadas, propostas por Alvarez, (2008, p. 104); Campomar e Ikeda, (2006, p. 13) para cada segmento de clientes, ainda são incipientes, podendo serem melhor desenvolvidas.

As formas mais utilizadas para segmentação dos canais foram pela organização, volume de compras e atratividade para o fornecedor, citadas por Cônsoli e D'Andrea, (2010, p. 128). Além disso, para algumas empresas a segmentação leva em consideração a região em que estão inseridas, corroborando com Alvarez, (2008, p. 104). Os critérios de segmentação dos canais de distribuição utilizados pelas empresas pesquisadas estão relacionados no Quadro 23.

Quadro 23 - Descrição das atividades relativas à segmentação desenvolvidas pelo Trade Marketing das empresas pesquisadas 


\begin{tabular}{|c|c|c|}
\hline Empresa & \multicolumn{2}{|c|}{ Atividades desenvolvidas com relação à Segmentação dos canais de distribuição } \\
\hline \multirow[t]{2}{*}{ EMS } & Marcas & $\begin{array}{ll}\text { - } & \text { Atratividade; } \\
\text { - } & \text { Região }\end{array}$ \\
\hline & Genéricos & $\begin{array}{ll}\text { - } & \text { Atratividade; } \\
\text { - } & \text { Região }\end{array}$ \\
\hline Zambon & \multicolumn{2}{|c|}{ - A segmentação não faz parte das atividades de Trade Marketing } \\
\hline Biolab & \multicolumn{2}{|c|}{$\begin{array}{ll}\text { - } & \text { Organização; } \\
\text { - } & \text { Volume de compras }\end{array}$} \\
\hline Sandoz & \multicolumn{2}{|c|}{$\begin{array}{ll}\text { - } & \text { Faturamento; } \\
\text { - } & \text { Região }\end{array}$} \\
\hline
\end{tabular}

Fonte: elaborado pela autora com base na pesquisa de campo

\subsubsection{Sistema de Informação de Trade Marketing}

As ações referentes ao sistema de informação de Trade Marketing, relacionadas por Alvarez (2008, p. 119), como a coleta contínua sobre marketing, vendas, mercado e clientes, são realizadas parcialmente pelas empresas estudadas. Grande parte das ações desenvolvidas são no sentido de alimentar o sistema de informação de marketing e vendas. Além disso, os casos também alimentam o sistema de informações dos canais de distribuição.

As ações de coleta de informações por inteligência descrita por Kotler e Keller (2006, p. 73) são: treinar a equipe de vendas para que relate acontecimentos; informações sobre ações de concorrentes; e comprar informações de fornecedores externos. Já a motivação para que os canais passem informações importantes não foi relatada em nenhum dos casos.

As informações que a equipe de campo traz para a empresa são mais relacionadas a preços e concorrentes. Em algumas empresas estudadas, como Sandoz, Biolab e Zambon, existe um treinamento ou um formulário que incentive a equipe a trazer informações do ponto de venda para a empresa. Já na EMS o retorno da informação pode ocorrer dependendo da próatividade do representante de vendas ou promotor. Todavia, os entrevistados consideram as informações de inteligência do promotor como uma contribuição importante e até como os "olhos" da empresa no PDV, e, por isso, pretendem implantar a atividade no futuro. Apenas a literatura de marketing faz menção a esta atividade (KOTLER; KELLER, 2006, p. 73).

$\mathrm{Na}$ análise de registros internos o departamento de Trade Marketing utiliza principalmente informações do sistema de informação de vendas e dados de clientes. Estas informações possibilitam a segmentação dos clientes e adequação do mix de produtos. Por fim, poucas empresas relataram ser responsáveis pela encomenda e análise de pesquisas. 
Entretanto, quando a pesquisa se refere a comportamento de shopper e canais de distribuição esta deveria ser uma função desempenhada pelo setor.

Uma das principais atividades desenvolvidas pelos departamentos de Trade Marketing é o que eles chamam de inteligência de Trade Marketing. Esta atividade trata-se da análise e distribuição de informações para alimentar os departamentos de marketing e comercial. Isso permite a segmentação dos canais, ajustes de preço, distribuição estratégica dos promotores ou representantes nas lojas e uma negociação mais efetiva, adequando o mix e quantidade de estoque do varejista às demandas do mercado.

O Quadro 24 apresenta a descrição das atividades relacionadas a Sistema de Informação de Trade Marketing desenvolvidas em cada uma das empresas estudadas.

Quadro 24 - Descrição das atividades relativas a Sistema de Informação desenvolvidas pelo Trade Marketing das empresas pesquisadas

\begin{tabular}{|c|c|c|}
\hline Empresa & \multicolumn{2}{|c|}{ Atividades desenvolvidas com relação a Sistema de Informação de Trade Marketing } \\
\hline \multirow[t]{2}{*}{ EMS } & Marcas & $\begin{array}{l}\text { - } \quad \text { Análise de dados de fornecedores externos } \\
\text { - } \quad \text { Distribuição das informações sobre o canal para o departamento comercial }\end{array}$ \\
\hline & Genéricos & $\begin{array}{l}\text { - Análise de dados de fornecedores externos } \\
\text { - } \quad \text { Distribuição das informações sobre o canal para o departamento comercial }\end{array}$ \\
\hline Zambon & $\begin{array}{ll}\text { - } & \mathrm{A} \\
\text { - } & \mathrm{D} \\
\text { - } & \mathrm{D} \\
\text { - } & \mathrm{C} \\
\text { - } & \mathrm{C} \\
& \mathrm{P}\end{array}$ & $\begin{array}{l}\text { de dados de fornecedores externos } \\
\text { uição das informações sobre o canal para o departamento comercial } \\
\text { uição das informações para os varejistas } \\
\text { de informações sobre preço } \\
\text { de informação sobre o preço dos concorrentes } \\
\text { sas de Trade Marketing }\end{array}$ \\
\hline Biolab & $\begin{array}{ll} & \mathrm{A} \\
\text { - } & \mathrm{D} \\
\text { - } & \mathrm{D} \\
\text { - } & \mathrm{C} \\
- & \mathrm{C} \\
- & \mathrm{P}\end{array}$ & $\begin{array}{l}\text { de dados de fornecedores externos } \\
\text { uição das informações sobre o canal para o departamento comercial } \\
\text { uição das informações para os varejistas } \\
\text { de informações sobre preço } \\
\text { de informação sobre o preço dos concorrentes } \\
\text { sas de Trade Marketing }\end{array}$ \\
\hline Sandoz & $\begin{array}{ll}\text { - } & \mathrm{A} \\
\text { - } & \mathrm{D} \\
\text { - } & \mathrm{D} \\
- & \mathrm{C} \\
- & \mathrm{C} \\
- & \mathrm{P}\end{array}$ & $\begin{array}{l}\text { de dados de fornecedores externos } \\
\text { uição das informações sobre o canal para o departamento comercial } \\
\text { uição das informações para os varejistas } \\
\text { de informações no ponto de venda sobre preço, produtos e ações } \\
\text { de informação sobre ações de concorrentes no ponto de venda } \\
\text { sas de Trade Marketing }\end{array}$ \\
\hline
\end{tabular}

Fonte: elaborado pela autora com base na pesquisa de campo 


\subsubsection{Comportamento do Shopper}

O processo de decisão de compra pode ser visto como um desafio para o Trade Marketing. Existem muitos atores neste processo que influenciam a compra. Dentre eles podemos citar o médico, o farmacêutico, o balconista, o comprador da farmácia, o consumidor e o shopper: ao médico cabe a decisão sobre o fármaco; ao comprador da farmácia a escolha das marcas que participarão do mix de produtos; ao farmacêutico a decisão sobre a marca do medicamento; ao shopper a aceitação ou não da marca escolhida pelo farmacêutico; e, finalmente, ao consumidor a adesão ou não ao tratamento proposto. Além disso, o medicamento é um produto indesejado pelo consumidor, ou seja, estes produtos não são comprados porque o consumidor quer, mas sim por necessidade. Com isso, o trabalho de Trade Marketing é muito mais complexo.

Para entender o comportamento do shopper, os departamentos de Trade Marketing são responsáveis por solicitar, analisar, coordenar e distribuir a informação obtida por meio de pesquisas de comportamento do shopper. Esta atividade está em consonância com o descrito por Cônsoli e D'Andrea (2010, p. 145).

O Quadro 25 descreve as atividades desenvolvidas por Trade Marketing em relação a comportamento do shopper nas empresas pesquisadas

Quadro 25 - Descrição das atividades relativas a comportamento do shopper desenvolvidas pelo Trade Marketing das empresas pesquisadas

\begin{tabular}{|l|c|c|c|}
\hline Empresa & \multicolumn{2}{|l|}{ Atividades desenvolvidas com relação a Comportamento do Shopper } \\
\hline EMS & Marcas & $\bullet$ & Análise da decisão de compra de produtos \\
\cline { 2 - 4 } & Genéricos & $\bullet$ & Análise da decisão de compra de produtos \\
\hline Zambon & $\bullet$ & Solicitar, analisar, coordenar as pesquisas sobre comportamento do shopper \\
\hline Biolab & $\bullet$ & Efetuar e analisar a pesquisa de comportamento do shopper \\
\hline Sandoz & $\bullet$ & Solicitar, analisar, coordenar as pesquisas sobre comportamento do shopper \\
\hline
\end{tabular}

Fonte: elaborado pela autora com base na pesquisa de campo

\subsubsection{Produto}

A variedade de embalagens primárias para fornecer diversas apresentações dos produtos, adequando-as aos diferentes canais de distribuição sugerida por Motta, Santos e Serralvo (2008, p. 53) não é aplicada nos casos estudados. Talvez no caso do setor farmacêutico este tipo de variedade não seja adequado, pois em primeiro lugar não existem 
diversos canais de distribuição e em segundo lugar, como trata-se de medicamentos, as embalagens são adequadas ao tempo de tratamento da patologia. Não foram relatadas as atividades mencionadas também por Motta, Santos e Serralvo (2008, p. 53) em relação a produtos de adequação a embalagens secundárias e oportunidades táticas.

Em algumas das empresas estudadas ainda não há um treinamento formal ou roteiro que contemple a avaliação de ações de concorrentes como o lançamento de produtos e participação do concorrente no mix do varejista. Isto ocorre apenas quando há uma próatividade do promotor em enviar informações para a empresa. Já o desempenho da linha de produtos é acompanhado por todas as empresas estudadas. A presença dos itens e níveis de estoque também são acompanhados pela maior parte das empresas, uma vez que a ruptura é um fato ruim para todos os elos da cadeia.

As sugestões para a ampliação da linha de produtos são efetuadas apenas pela Sandoz, enquanto a adequação do mix de acordo com o cliente é uma preocupação de todas as empresas. Esta adequação de mix é uma orientação fornecida ao varejista sobre quais produtos e qual a quantidade ideal de acordo com o perfil dos consumidores que são atendidos pela farmácia.

Em relação a atratividade de embalagens, podem ser adotadas duas vertentes. A primeira é sobre o desempenho e melhorias que podem ser efetuadas na embalagem a fim de que o produto fique melhor exposto no ponto de venda. Outra vertente é a verificação da presença de embalagens danificadas no ponto de venda.

O Quadro 26 apresenta as atividades realizadas pelas empresas pesquisadas relativas a produto.

Quadro 26 - Descrição das atividades relativas a produto desenvolvidas pelo Trade Marketing das empresas pesquisadas

\begin{tabular}{|l|l|r|l|}
\hline Empresa & \multicolumn{2}{|l|}{ Atividades desenvolvidas em relação a Produto } \\
\hline EMS & Marcas & $\bullet$ & Avaliação de concorrentes quando necessário; \\
& & $\bullet$ & Verificação do desempenho da linha; \\
& & $\bullet$ & Adequação do mix de acordo com o cliente; \\
& & $\bullet$ & Adequação da embalagem quando necessário \\
\cline { 2 - 5 } & Genéricos & $\bullet$ & Suporte ao departamento comercial; \\
& & $\bullet$ & Adequação do mix de acordo com o cliente; \\
& & $\bullet$ & Adequação da embalagem quando necessário. \\
\hline Zambon & $\bullet$ & Verificação do desempenho da linha de produtos no cliente; \\
& $\bullet$ & Adequação do mix de produto de acordo com o varejista. \\
\hline Biolab & $\bullet$ & \multicolumn{3}{|c|}{ Verificação do desempenho da linha de produtos no cliente; } \\
\hline
\end{tabular}




\begin{tabular}{|l|ll|}
\hline & • & Adequação do mix de produto de acordo com o varejista; \\
& • & Verificação da presença dos itens. \\
\hline Sandoz & • & Ações para divulgação do lançamento de produtos; \\
& • & Verificação do desempenho da linha; \\
& - Verificação da presença dos itens; \\
& - Sugestão de ampliação da linha; \\
& - & Adequação do mix de acordo com o cliente. \\
\hline
\end{tabular}

Fonte: elaborado pela autora com base na pesquisa de campo

\subsubsection{Preço}

O acompanhamento dos preços praticados pelos varejistas é importante, pois estes não podem estar acima ou abaixo da faixa desejada, o que poderia desposicionar a marca e criar conflitos entre os canais. A informação sobre os preços dos concorrentes é função do Trade Marketing, pois por meio dele é possível verificar as estratégias dos concorrentes por ponto de venda. Além disso, esta informação chega a uma velocidade maior do que se efetuada de outra forma. Já a elasticidade de preços pode ser verificada pelo departamento de Trade Marketing quando for baseada na elasticidade do shopper. Entretanto, nenhuma das empresas pesquisadas desenvolve esta ação.

O produtor tem pouco controle sobre a formação de preços do varejista. Por esse motivo não é possível controlar o preço. Nestes casos é necessário a tentativa de conscientizar sobre a importância de manter o produto em uma faixa preço determinada o varejista por meio do relacionamento e negociação. No geral, esta orientação é passada para o departamento comercial, o qual orienta o varejista.

O Quadro 27 apresenta as atividades relativas a preço desenvolvidas pelos departamentos de Trade Marketing nas empresas estudadas.

Quadro 27 - Descrição das atividades relativas a preço desenvolvidas pelo Trade Marketing das empresas pesquisadas

\begin{tabular}{|c|c|c|}
\hline $\begin{array}{l}\text { Empresa } \\
\text { EMS }\end{array}$ & \multicolumn{2}{|c|}{ Atividades desenvolvidas com relação a Preço } \\
\hline EMS & Marcas & $\begin{array}{l}\text { - Acompanha preços praticados pelos varejistas } \\
\text { - Acompanha preço de produtos concorrentes praticados pelos varejistas } \\
\text { - Evita conflito de canais } \\
\text { - Orienta o varejista quando há inadequação na faixa de preço desejada }\end{array}$ \\
\hline & Genéricos & $\begin{array}{l}\text { - } \\
\text { - Acompanha preços praticados pelos varejistas } \\
\text { - } \quad \text { Evita conflito de canais } \\
\text { - } \quad \text { Orienta o varejista quando há inadequação na faixa de preço desejada }\end{array}$ \\
\hline
\end{tabular}




\begin{tabular}{|l|l|l|}
\hline Zambon & - Acompanha preços praticados pelos varejistas \\
& - Acompanha preços de produtos concorrentes praticados pelos varejistas \\
\hline Biolab & - Acompanha preços praticados pelos varejistas \\
& - Acompanha preços de produtos concorrentes praticados pelos varejistas \\
\hline Sandoz & - & Participa na formação do preço \\
& - Acompanha preços praticados pelos varejistas \\
& - Acompanha preços de produtos concorrentes praticados pelos varejistas \\
& - Evita conflito de canais \\
& - Orienta o varejista quando há inadequação na faixa de preço desejada \\
\hline
\end{tabular}

Fonte: elaborado pela autora com base na pesquisa de campo

\subsubsection{Comunicação}

As principais atividades que o Trade Marketing desenvolve em termos de comunicação são as relacionadas à elaboração de materiais de comunicação no PDV e ao merchandising. A negociação de espaços no varejista é efetuada em conjunto com o departamento comercial. As promoções de vendas sofrem diversas restrições legais no setor farmacêutico (BRASIL, 2008). Sendo assim, a principal promoção de vendas realizada é a distribuição de brindes para a equipe do canal.

O desenvolvimento de materiais de comunicação no PDV foi citado por todas as empresas. Para inserir estes materiais em uma farmácia deve-se efetuar uma negociação ou utilizar o relacionamento para que seja autorizada a colocação destes materiais. Outro fato interessante é que algumas empresas se mostraram temerosas em relação a uma ação muito ostensiva de materiais no PDV, pois acreditam que isso pode criar um conflito com a prescrição médica.

A exposição do medicamento genérico parece ser fundamental para a venda do produto e é um grande foco das empresas que têm esta linha. Mesmo os medicamentos sob prescrição médica, quando são genéricos prefere-se a exposição de toda a marca em conjunto. A exposição também é importante para a categoria de OTC, pois estes podem ficar nas prateleiras ao alcance do consumidor. Entretanto, as ações de merchandising também dependem de negociação ou relacionamento com o varejista, pois é necessária autorização para que o produtor altere a exposição dos produtos. Além disso, as farmácias de rede costumam ter seus próprios planogramas. O desenvolvimento de atividades de merchandising está descrito na literatura como responsabilidade do Trade Marketing e este fato foi confirmado pela pesquisa de campo (ALVAREZ, 2008, p. 144; MOTTA; SANTOS; SERRALVO, 2008, p. 62). 
Todas as empresas pesquisadas comentaram sobre a participação do departamento de Trade Marketing na organização de feiras e eventos. Entretanto, a literatura de Trade Marketing não comenta sobre esta atividade, mas a literatura sobre canais de distribuição aborda o assunto (ROSENBLOOM, 2008, p. 315). Já a literatura sobre comunicação de marketing afirma que os eventos são uma ferramenta de promoção de marketing que possibilita contato com público específico (CRESCITELLI; SHIMP, 2012). Dessa forma, esta atividade deve ser desempenhada pelo Trade Marketing, uma vez que o evento é relacionado com os varejistas e distribuidores, proporcionando uma forma de relacionamento com estes clientes e suas equipes e, assim, divulgando a marca e produtos da empresa para este público. No setor farmacêutico estes eventos são muito comuns e tornaram-se um ponto de encontro para os profissionais que atuam no setor.

Principalmente pela dificuldade de comunicação de medicamentos devido à legislação da área, feiras e congressos tornam-se uma ferramenta alternativa para divulgação das marcas. Outra ferramenta amplamente utilizada é a inserção de produtos ou da marca no tabloide do varejista. Na literatura esta atividade é descrita como uma ação cooperada. Entretanto, pelo que foi visto, este espaço é cobrado (MOTTA; SANTOS; SERRALVO, 2008, p. 62; ROSENBLOOM, 2008, p. 306; ROSLOW; LASKEY; NICHOLLS, 1993).

Para todas as ferramentas de comunicação que os produtores desejam desenvolver no ponto de venda, é necessário efetuar uma negociação ou agir por meio do relacionamento, conseguindo a autorização do varejista para tal ação. Esta negociação pode ser feita pelo departamento comercial com o auxílio do departamento de Trade Marketing. Além disso, uma vez que estas ações são negociadas, é necessário que haja uma fiscalização para verificar se o varejista está cumprindo o que foi acordado. A fiscalização também faz parte das atribuições do Trade Marketing.

No Quadro 28 estão descritas as atividades relacionadas à comunicação desenvolvidas pelas empresas pesquisadas.

Quadro 28 - Descrição das atividades relativas à comunicação desenvolvidas pelo Trade Marketing das empresas pesquisadas

\begin{tabular}{|c|c|c|}
\hline Empresa & \multicolumn{2}{|c|}{ Atividades desenvolvidas com relação a Comunicação } \\
\hline EMS & Marcas & $\begin{array}{ll}\text { - } & \text { Promoção de vendas (brindes somente para o canal) } \\
\text { - } & \text { Merchandising } \\
\text { - } & \text { Materiais de PDV } \\
\text { - } & \text { Ações cooperadas (tabloides) } \\
\text { - } & \text { Eventos (feiras e congressos) } \\
\text { - } & \text { Auxilio ao departamento comercial na negociação de espaços com o } \\
\text { varejista }\end{array}$ \\
\hline
\end{tabular}




\begin{tabular}{|c|c|c|}
\hline & & - $\quad$ Fis \\
\hline & Genéricos & $\begin{array}{ll}\text { - } & \text { Promoção de vendas (brindes somente para o canal) } \\
\text { - } & \text { Merchandising } \\
\text { - } & \text { Materiais de PDV } \\
\text { - } & \text { Ações cooperadas (tabloides) } \\
\text { - } & \text { Eventos (feiras e congressos) } \\
\text { - } & \text { Auxilio ao departamento comercial na negociação de espaços com o } \\
& \text { varejista } \\
\text { - } & \text { Fiscalização das ações negociadas }\end{array}$ \\
\hline Zambon & \multicolumn{2}{|c|}{$\begin{array}{ll}\text { - } & \text { Promoção de vendas (brindes somente para o canal) } \\
\text { - } & \text { Merchandising } \\
\text { - } & \text { Materiais de PDV } \\
\text { - } & \text { Ações cooperadas (tabloides) } \\
\text { - } & \text { Eventos (feiras e congressos) } \\
\text { - } & \text { Auxilio ao departamento comercial na negociação de espaços com o varejista } \\
\text { - } & \text { Fiscalização das ações negociadas }\end{array}$} \\
\hline Biolab & \multicolumn{2}{|c|}{$\begin{array}{ll}\text { - } & \text { Promoção de vendas (brindes somente para o canal) } \\
\text { - } & \text { Merchandising } \\
\text { - } & \text { Materiais de PDV } \\
\text { - } & \text { Ações cooperadas (tabloides) } \\
\text { - } & \text { Eventos (feiras e congressos) } \\
\text { - } & \text { Auxilio ao departamento comercial na negociação de espaços com o varejista } \\
\text { - } & \text { Fiscalização das ações negociadas }\end{array}$} \\
\hline Sandoz & \multicolumn{2}{|c|}{$\begin{array}{ll}\text { - } & \text { Promoção de vendas (brindes somente para o canal) } \\
\text { - } & \text { Merchandising } \\
\text { - } & \text { Materiais de PDV } \\
\text { - } & \text { Ações cooperadas (tabloides) } \\
\text { - } & \text { Eventos (feiras e congressos) } \\
\text { - } & \text { Auxilio ao departamento comercial na negociação de espaços com o varejista } \\
\text { - } & \text { Fiscalização das ações negociadas }\end{array}$} \\
\hline
\end{tabular}

Fonte: elaborado pela autora com base na pesquisa de campo

\subsubsection{Gerenciamento de categoria}

Auxiliar o gerenciamento de categorias é uma atividade pouco executada pelas indústrias pesquisadas. Entretanto, de acordo com a literatura, é uma atividade do Trade Marketing (ALVAREZ, 2008).

O que pode ser observado em relação ao gerenciamento de categorias é que as empresas que tem um departamento de Trade Marketing mais estruturado auxiliam o varejista neste quesito. O que ocorre também é que o gerenciamento de categorias é uma função do varejista e quando este não a desenvolve, não é possível que a indústria forneça auxilio.

Sendo assim, quando as empresas lidam com uma rede, que é mais profissionalizada, o Trade Marketing pode auxiliar no gerenciamento por categorias e acompanhar os resultados 
da categoria. Já em farmácias menos profissionalizadas, o Trade Marketing precisa ensinar para o varejista o que é gerenciamento de categorias e como fazê-lo. O planograma pode ser desenvolvido para algumas categorias, como OTC, suplementos e dermocosméticos, conforme a sugestão da literatura (ALVAREZ, 2008, p. 67). Já para medicamentos de prescrição, a exposição é efetuada em ordem alfabética e o planograma não se aplica nestes casos. O Quadro 29 descreve as atividades relacionadas ao gerenciamento de categorias nas empresas estudadas.

Quadro 29 - Descrição das atividades relativas a gerenciamento de categorias desenvolvidas pelo Trade Marketing das empresas pesquisadas

\begin{tabular}{|c|c|c|}
\hline Empresa & \multicolumn{2}{|c|}{ Atividades desenvolvidas com relação ao gerenciamento de categoria } \\
\hline \multirow[t]{2}{*}{ EMS } & Marcas & - Não desenvolvem atividades com relação a gerenciamento de categorias \\
\hline & Genéricos & $\begin{array}{l}\text { - } \quad \text { Auxilia o varejista na formação de categorias } \\
\text { - }\end{array}$ \\
\hline Zambon & \multicolumn{2}{|c|}{ - Não desenvolvem atividades com relação a gerenciamento de categorias } \\
\hline Biolab & \multicolumn{2}{|c|}{$\begin{array}{l}\text { - } \text { Auxilia o varejista na formação de categorias } \\
\text { - } \quad \text { Avalia o desempenho da categoria de dermocosméticos } \\
\text { - } \quad \text { Tem planograma para a categoria de dermocosméticos }\end{array}$} \\
\hline Sandoz & \multicolumn{2}{|c|}{$\begin{array}{l}\text { - } \quad \text { Auxilia o varejista na formação de categorias } \\
\text { - } \quad \text { Avalia o desempenho das categorias }\end{array}$} \\
\hline
\end{tabular}

Fonte: elaborado pela autora com base na pesquisa de campo

\subsubsection{Relacionamento com o cliente}

O treinamento aparece como uma das principais atividades desenvolvidas para estabelecer o relacionamento com os clientes. Com as restrições legais do setor em relação a comunicação de medicamentos, o relacionamento parece ser uma forma importante para a comunicação com os canais. Todas as empresas pesquisadas mencionaram desenvolver algum tipo de programa de treinamentos para distribuidores e varejistas. Sendo assim, a pesquisa de campo encontrou o mesmo que foi descrito pela literatura (CÔNSOLI; D'ANDREA, 2010, p. 117; ROSENBLOOM, 2008, p. 312).

Uma inovação na forma de se relacionar com os canais e ao mesmo tempo passar informações para as equipes de vendas foi o desenvolvimento de plataformas de treinamento online e de aplicativos para celular. A participação no processo de remuneração e incentivos à equipe dos canais não são utilizados no setor devido às restrições legais. Sendo assim, há uma contrariedade com relação ao estabelecido na teoria (CÔNSOLI; D'ANDREA, 2010, p. 117).

As ações em colaboração com o cliente, como o compartilhamento de informações e programas de suporte para melhorias nas operações do canal mencionadas por Cônsoli e 
D'Andrea (2010, p. 117) são praticamente inexistentes nos casos pesquisados, sendo apontadas apenas por uma das empresas. Não há utilização de indicadores de desempenho em conjunto, como descrito por Cônsoli e D'Andrea (2010, p. 117). As atividades relativas ao relacionamento com os canais de distribuição executadas pelos casos estudados estão relacionadas no Quadro 30.

Quadro 30 - Descrição das atividades relativas a sistema de informação desenvolvidas pelo Trade Marketing das empresas pesquisadas

\begin{tabular}{|c|c|c|}
\hline Empresa & \multicolumn{2}{|c|}{ Atividades desenvolvidas com relação a Relacionamento com os Canais de Distribuição } \\
\hline \multirow[t]{2}{*}{ EMS } & Marcas & $\begin{array}{ll}\text { - } & \text { Treinamentos para a equipe de vendas do canal } \\
\text { - } & \text { Desenvolvimento de aplicativos e portais }\end{array}$ \\
\hline & Genéricos & $\begin{array}{l}\text { - Treinamentos para a equipe de vendas do canal } \\
\text { - } \quad \text { Desenvolvimento de aplicativos e portais }\end{array}$ \\
\hline Zambon & \multicolumn{2}{|c|}{ - Treinamentos para a equipe de vendas do canal } \\
\hline Biolab & \multicolumn{2}{|c|}{ - $\quad$ Treinamentos para a equipe de vendas do canal } \\
\hline Sandoz & \multicolumn{2}{|c|}{$\begin{array}{l}\text { - } \text { Treinamentos para a equipe de vendas do canal } \\
\text { - } \quad \text { Desenvolvimento de portais } \\
\text { - } \quad \text { Programa de suporte para melhorias nas operações do canal; } \\
\text { - } \quad \text { Compartilhamento de informações; }\end{array}$} \\
\hline
\end{tabular}

Fonte: elaborado pela autora com base na pesquisa de campo

\subsubsection{Plano de Trade Marketing}

As empresas estudadas efetuam o plano de Trade Marketing, não somente para as contas-chave ou segmentos de clientes como sugerido por Alvarez, (2008, p. 123) O desenvolvimento de um plano do fabricante em conjunto com o varejista colocado por Shankar et al., (2011) ocorre em alguns dos casos pesquisados. O Quadro 31 apresenta os principais achados em relação às atividades desenvolvidas pelo Trade marketing para a confecção de um plano da área nos casos estudados.

Quadro 31 - Descrição das atividades relativas ao Plano de Trade Marketing desenvolvidas pelo Trade Marketing das empresas pesquisadas

\begin{tabular}{|c|c|c|}
\hline Empresa & \multicolumn{2}{|c|}{ Atividades desenvolvidas com relação à elaboração do Plano de Trade Marketing } \\
\hline \multirow[t]{2}{*}{ EMS } & Marcas & $\begin{array}{l}\text { - Apresentação que contempla metas cronograma e programa de ação. } \\
\text { - O orçamento de Trade Marketing está inserido no orçamento de marketing. } \\
\text { - As ações são feitas de acordo com a demanda }\end{array}$ \\
\hline & Genéricos & $\begin{array}{l}\text { - Apresentação que contempla metas, cronograma e programa de ação. } \\
\text { - } \quad \text { Orçamento próprio }\end{array}$ \\
\hline Zambon & \multicolumn{2}{|c|}{$\begin{array}{l}\text { - Há um plano de Trade Marketing que descreve o momento atual em que a marca se } \\
\text { encontra, os objetivos e calendário de ações promocionais }\end{array}$} \\
\hline Biolab & \multicolumn{2}{|c|}{$\begin{array}{l}\text { - } \quad \text { Plano de Trade Marketing anual } \\
\text { - } \quad \text { Plano em conjunto com os canais } \\
\text { - } \quad \text { Orçamento por demanda }\end{array}$} \\
\hline Sandoz & \multicolumn{2}{|c|}{ - $\quad$ Plano de Trade Marketing está contido no plano de marketing } \\
\hline
\end{tabular}




\begin{tabular}{|l|l|}
\hline & - Efetuado anualmente \\
& - Especificadas as ações em cada tipo de canal \\
- Apresentação do plano regional e global \\
- Ompartilham o plano com os principais clientes \\
- Os principais clientes compartilham seus planos com a empresa
\end{tabular}

Fonte: elaborado pela autora com base na pesquisa de campo

\subsubsection{Métricas de Trade Marketing}

Assim como as ações de marketing, é muito desafiador determinar métricas eficientes para as ações de Trade Marketing. Algumas ações ainda não são mensuradas pela ausência de uma métrica adequada, pois são relacionadas a atividades mais intangíveis como desenvolvimento do relacionamento, por exemplo. A métrica mais usada é o ROI, mencionado por Cônsoli e D'Andrea (2010, p. 234). Além disso, as empresas utilizam o sell in e sell out, corroborando com a literatura (ALVAREZ, 2008). Outras métricas utilizadas são resultados de vendas, participação de mercado e rentabilidade como sugerido por Motta, Santos e Serralvo (2008, p. 83).

As métricas devem ser estipuladas de acordo com as ações efetuadas pelo Trade Marketing e objetivos das ações. Ainda há uma área a ser explorada pelo Trade Marketing com relação a uso de indicadores.

O Quadro 32 apresenta as métricas utilizadas pelo Trade Marketing nas empresas estudadas.

Quadro 32 - Descrição das métricas de Trade Marketing utilizadas pelas empresas pesquisadas

\begin{tabular}{|c|c|c|}
\hline $\begin{array}{l}\text { Empresa } \\
\text { EMS }\end{array}$ & \multicolumn{2}{|c|}{ Métricas de Trade Marketing utilizadas pelos casos estudados } \\
\hline \multirow[t]{2}{*}{ EMS } & Marcas & $\begin{array}{ll}\text { - } & \text { Resultados de vendas } \\
\text { - } & \text { Participação de mercado } \\
\text { - } & \text { Rentabilidade } \\
\text { - } & \text { Selling out e Selling in } \\
\text { - } & \text { Return on Investment (ROI) }\end{array}$ \\
\hline & Genéricos & $\begin{array}{ll}\text { - } & \text { Resultados de vendas } \\
\text { - } & \text { Participação de mercado } \\
\text { - } & \text { Rentabilidade } \\
\text { - } & \text { Selling out e Selling in } \\
\text { - } & \text { Return on Investment (ROI) }\end{array}$ \\
\hline Zambon & $\begin{array}{ll}\text { - } & \mathrm{R} \\
\text { - } & \mathrm{P} \\
\text { - } & \mathrm{R} \\
\text { - } & S c \\
\text { - } & R\end{array}$ & $\begin{array}{l}\text { dos de vendas } \\
\text { ação de mercado } \\
\text { lidade } \\
\text { out e Selling in } \\
\text { on Investment (ROI) }\end{array}$ \\
\hline
\end{tabular}




\begin{tabular}{|l|l|l|}
\hline & $\bullet$ & Preços praticados na ponta \\
\hline Biolab & - Resultados de vendas \\
& - Participação de mercado \\
& - Rentabilidade \\
& - Selling out e Selling in \\
& - Return on Investment (ROI) \\
\hline Sandoz & - Preços praticados na ponta \\
& - Participação de mercado \\
& - Rentabilidade \\
& - Selling out e Selling in \\
& - Return on Investment (ROI) \\
& Preços praticados na ponta \\
\hline
\end{tabular}

Fonte: elaborado pela autora com base na pesquisa de campo

\subsubsection{Outras Considerações}

A EMS Marcas é responsável por toda a parte de marketing digital da divisão. Esta atividade não pertence a Trade Marketing, exceto quando o objetivo é a comunicação com o canal.

Dentre os desafios encontra-se o poder do varejista, que afeta principalmente o mercado de genéricos. Isto ocorre porque o segmento do similar são as médias e pequenas redes e as farmácias independentes. Já o genérico está presente também nas grandes redes. Estas têm um poder de barganha maior, principalmente as redes da cidade de São Paulo, que são mais organizadas.

As restrições legais em relação a promoção no setor são outro desafio. A indústria farmacêutica somente pode comunicar, para o consumidor, os medicamentos isentos de prescrição. Entretanto, a comunicação pode ser feita para os profissionais que efetuam a prescrição e a dispensação. Assim, pode-se perceber que a legislação é um desafio para o desenvolvimento das atividades de marketing, e talvez por isso, o Trade Marketing pode ser visto como uma solução para contornar a grande regulação do setor em relação a comunicação. O processo de decisão de compra também pode ser visto como desafio para o Trade Marketing. Existem muitos atores neste processo que influenciam a compra. Com isso, o trabalho de Trade Marketing é muito mais complexo.

O desconhecimento do varejista sobre seu próprio negócio e das ferramentas de gestão configura mais um desafio no setor. $\mathrm{O}$ varejista não efetua corretamente a gestão do estoque, não conhece os conceitos de curva $\mathrm{ABC}$, rentabilidade e gerenciamento de categorias. Isto acaba prejudicando a venda de produtos e afeta a indústria farmacêutica. 
Por fim, o compliance foi muito citado, principalmente nas indústrias multinacionais. Em alguns casos o compliance é mais severo que a própria legislação do setor e acaba interferindo nas ações de Trade Marketing. Diversas ações não podem ser feitas de acordo com as normas da empresa, corroborando com a afirmação de Mazzero, (2014) que o setor tem regras severas de compliance.

A Tabela 3 apresenta a comparação entre as atividades de Trade Marketing evidenciadas na pesquisa de campo com o que foi descrito na literatura.

Tabela 3 - Comparação das atividades evidenciadas na pesquisa de campo com a literatura

\begin{tabular}{|c|c|c|}
\hline \multicolumn{2}{|r|}{ Atividade } & Literatura \\
\hline \multicolumn{3}{|c|}{ Segmentação dos canais de distribuição } \\
\hline $\begin{array}{l}\text { Descrito na literatura e } \\
\text { verificado na pesquisa de campo }\end{array}$ & $\begin{array}{l}\text { - } \quad \text { Volume de compras } \\
\text { - } \quad \text { Organização do varejista } \\
\text { - }\end{array}$ & $\begin{array}{l}\text { (CÔNSOLI; D'ANDREA, 2010, p. } \\
128)\end{array}$ \\
\hline $\begin{array}{l}\text { Descrito na literatura, mas não } \\
\text { verificado na pesquisa de campo }\end{array}$ & $\begin{array}{l}\text { - Posicionamento do varejista } \\
\text { - Público-alvo do canal } \\
\text { - Número de check-outs } \\
\text { - Formato }\end{array}$ & $\begin{array}{l}\text { (CÔNSOLI; D'ANDREA, 2010, p. } \\
128)\end{array}$ \\
\hline 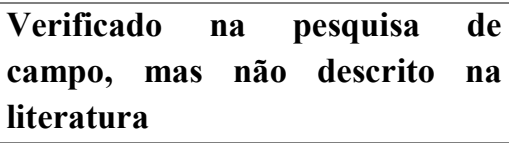 & $\begin{array}{ll}\text { - } & \text { Região } \\
\text { - } & \text { Faturamento do canal }\end{array}$ & Não se aplica \\
\hline \multicolumn{3}{|c|}{ Sistema de Informação de Trade Marketing } \\
\hline $\begin{array}{l}\text { Descrito na literatura e } \\
\text { verificado na pesquisa de campo }\end{array}$ & $\begin{array}{l}\text { - Análise de dados de } \\
\text { fornecedores externos } \\
\text { - Coleta de informações no } \\
\text { ponto de venda sobre preço, } \\
\text { produtos e ações } \\
\text { - Coleta de informação sobre } \\
\text { ações de concorrentes no ponto } \\
\text { de venda } \\
\text { - Pesquisas de Trade Marketing }\end{array}$ & (KOTLER; KELLER, 2006, p. 73) \\
\hline $\begin{array}{l}\text { Descrito na literatura, mas não } \\
\text { verificado na pesquisa de campo }\end{array}$ & $\begin{array}{l}\text { Coleta sistemática e contínua } \\
\text { sobre: } \\
\text { - Marketing: posicionamento, } \\
\text { estratégias de produto, } \\
\text { estratégias de comunicação, } \\
\text { ações para o lançamento de } \\
\text { novos produtos, programação } \\
\text { anual de comunicação e metas } \\
\text { para o portfólio de produtos. } \\
\text { - Vendas: Políticas comerciais, } \\
\text { estrutura da equipe, } \\
\text { atendimento a clientes, } \\
\text { cobertura do mercado, metas } \\
\text { dos produtos e clientes } \\
\text { Clientes: ambiente competitivo } \\
\text { do cliente, operação, }\end{array}$ & (ALVAREZ, 2008, p. 119) \\
\hline
\end{tabular}




\begin{tabular}{|c|c|c|}
\hline & $\begin{array}{l}\text { monitoramento de desempenho } \\
\text { das ações desenvolvidas com o } \\
\text { cliente, acompanhamento de } \\
\text { metas por clientes. }\end{array}$ & \\
\hline $\begin{array}{l}\text { Verificado na pesquisa } \\
\text { campo, mas não descrito na } \\
\text { literatura }\end{array}$ & $\begin{array}{l}\text { - Distribuição das informações } \\
\text { sobre o canal para o } \\
\text { departamento comercial } \\
\text { - Distribuição das informações } \\
\text { para os varejistas }\end{array}$ & Não se aplica \\
\hline \multicolumn{3}{|c|}{ Comportamento do shopper } \\
\hline $\begin{array}{l}\text { Descrito na literatura e } \\
\text { verificado na pesquisa de campo }\end{array}$ & $\begin{array}{l}\text { - Realização de pesquisas sobre } \\
\text { comportamento do shopper }\end{array}$ & $\begin{array}{l}\text { (CÔNSOLI; D'ANDREA, 2010, p } \\
129)\end{array}$ \\
\hline $\begin{array}{l}\text { Descrito na literatura, mas não } \\
\text { verificado na pesquisa de campo }\end{array}$ & $\begin{array}{l}\text { - Segmentação dos shoppers dos } \\
\text { canais de distribuição }\end{array}$ & $\begin{array}{l}\text { (CÔNSOLI; D'ANDREA, 2010, p } \\
129)\end{array}$ \\
\hline $\begin{array}{l}\text { Verificado na pesquisa } \\
\text { campo, mas não descrito na } \\
\text { literatura }\end{array}$ & - Não houve atividade & Não se aplica \\
\hline \multicolumn{3}{|c|}{ Produto } \\
\hline $\begin{array}{l}\text { Descrito na literatura e } \\
\text { verificado na pesquisa de campo }\end{array}$ & $\begin{array}{l}\text { - Avaliar ações de produtos } \\
\text { concorrentes; } \\
\text { - Verificar o desempenho da } \\
\text { linha de produtos; } \\
\text { - Verificar a presença de itens } \\
\text { - Atratividade da embalagem } \\
\text { - Sugerir novos produtos } \\
\text { - Orientar o canal sobre o mix de } \\
\text { produtos }\end{array}$ & (ALVAREZ, 2008, p. 90) \\
\hline $\begin{array}{l}\text { Descrito na literatura, mas não } \\
\text { verificado na pesquisa de campo }\end{array}$ & $\begin{array}{l}\text { - Embalagem primária } \\
\text { - Embalagem secundária } \\
\text { - Oportunidades táticas } \\
\text { - Aplicar o posicionamento } \\
\text { definido pelo marketing } \\
\text { - Garantir a visibilidade dos } \\
\text { produtos }\end{array}$ & $\begin{array}{l}\text { (MOTTA; } \\
\text { SERRALVO, 2008, p. 53; } \\
\text { ALVAREZ, 2008, p. 90)) }\end{array}$ \\
\hline $\begin{array}{l}\text { Verificado na pesquisa } \\
\text { campo, mas não descrito na } \\
\text { literatura }\end{array}$ & - Não houve atividade & Não se aplica \\
\hline \multicolumn{3}{|c|}{ Preço } \\
\hline $\begin{array}{l}\text { Descrito na literatura e } \\
\text { verificado na pesquisa de campo }\end{array}$ & $\begin{array}{l}\text { - } \text { Acompanhar os preços } \\
\text { praticados pelo canal } \\
\text { - Acompanhar os preços de } \\
\text { produtos concorrentes } \\
\text { praticados pelo canal } \\
\text { - Evitar conflito de canais } \\
\text { - Orientar varejista quando } \\
\text { houver inadequações } \\
\text { - Participar da formação de } \\
\text { preços }\end{array}$ & $\begin{array}{l}\text { (ALVAREZ, 2008, p. } 92 ; \\
\text { CÔNSOLI; D'ANDREA, 2010, p. } \\
\text { 136) }\end{array}$ \\
\hline Descrito na literatura, mas não & - Avaliar a elasticidade de & (ALVAREZ, \\
\hline
\end{tabular}




\begin{tabular}{|c|c|c|}
\hline verificado na pesquisa de campo & $\begin{array}{ll} & \text { preços } \\
\text { - Acompanhar margens e giro }\end{array}$ & $\begin{array}{l}\text { CÔNSOLI; D'ANDREA, 2010, p. } \\
136)\end{array}$ \\
\hline $\begin{array}{l}\text { Verificado na pesquisa } \\
\text { campo, mas não descrito na } \\
\text { literatura }\end{array}$ & - Não houve atividade & Não se aplica \\
\hline \multicolumn{3}{|c|}{ Comunicação } \\
\hline $\begin{array}{l}\text { Descrito na literatura e } \\
\text { verificado na pesquisa de campo }\end{array}$ & $\begin{array}{l}\text { - Promoção de vendas: brindes } \\
\text { - } \text { somente para o canal } \\
\text { - Materiais de PDV } \\
\text { - Ações cooperadas (tabloides) } \\
\text { - Eventos (feiras e congressos) }\end{array}$ & 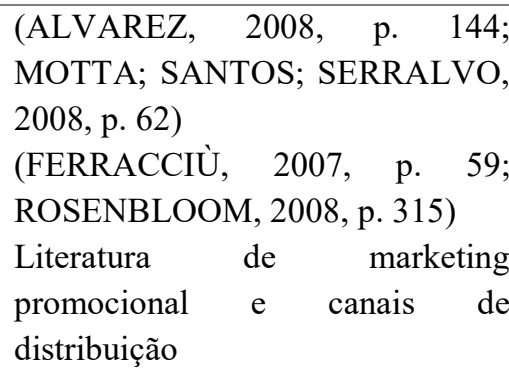 \\
\hline $\begin{array}{l}\text { Descrito na literatura, mas não } \\
\text { verificado na pesquisa de campo }\end{array}$ & $\begin{array}{lll}\text { - } & \text { Promoção } & \text { de } \\
\text { degustação, } & \text { concursos } \\
\text { sorteios } & \end{array}$ & $\begin{array}{l}\text { (MOTTA; } \\
\text { SERRALVO, 2008, p. 62) }\end{array}$ \\
\hline $\begin{array}{l}\text { Verificado na pesquisa } \\
\text { campo, mas não descrito na } \\
\text { literatura }\end{array}$ & $\begin{array}{l}\text { - Auxilia o departamento } \\
\text { comercial na negociação de } \\
\text { espaços com o varejista } \\
\text { - } \text { Fiscaliza as ações negociadas }\end{array}$ & Não se aplica \\
\hline \multicolumn{3}{|c|}{ Gerenciamento de Categorias } \\
\hline $\begin{array}{l}\text { Descrito na literatura e } \\
\text { verificado na pesquisa de campo }\end{array}$ & $\begin{array}{l}\text { - Auxiliar o varejista a avaliar a } \\
\text { categoria } \\
\text { - Sugerir variedade de produtos } \\
\text { e marcas } \\
\text { - Preparar planogramas } \\
\text { - Acompanhar os resultados das } \\
\text { categorias em conjunto com o } \\
\text { varejista }\end{array}$ & (ALVAREZ, 1999, p. 67) \\
\hline $\begin{array}{l}\text { Descrito na literatura, mas não } \\
\text { verificado na pesquisa de campo }\end{array}$ & - Não houve atividade & Não se aplica \\
\hline 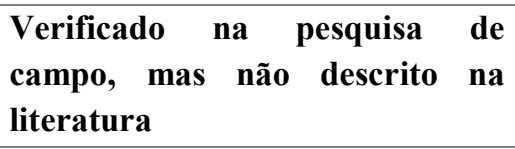 & $\begin{array}{l}\text { - Auxilia o varejista na formação } \\
\text { de categorias }\end{array}$ & Não se aplica \\
\hline \multicolumn{3}{|c|}{ Relacionamento com os Canais de Distribuição } \\
\hline $\begin{array}{l}\text { Descrito na literatura e } \\
\text { verificado na pesquisa de campo }\end{array}$ & $\begin{array}{l}\text { - Treinamentos para a equipe de } \\
\text { vendas do canal } \\
\text { - Programa de suporte para } \\
\text { melhorias nas operações do } \\
\text { canal; } \\
\text { - Compartilhamento } \\
\text { informações; }\end{array}$ & $\begin{array}{l}\text { (CÔNSOLI; D'ANDREA, 2010, p. } \\
117 ; \text { ROSENBLOOM, 2008, p. } \\
312 \text {. }\end{array}$ \\
\hline $\begin{array}{l}\text { Descrito na literatura, mas não } \\
\text { verificado na pesquisa de campo }\end{array}$ & $\begin{array}{l}\text { - Participação no processo de } \\
\text { remuneração; } \\
\text { - Programas de incentivos para a } \\
\text { equipe do canal; } \\
\text { - Utilização de indicadores de } \\
\text { desempenho em conjunto; }\end{array}$ & $\begin{array}{l}\text { (CÔNSOLI; D'ANDREA, 2010, p. } \\
117 \text { ) }\end{array}$ \\
\hline $\begin{array}{l}\text { Verificado na pesquisa } \\
\text { campo, mas não descrito na }\end{array}$ & $\begin{array}{l}\text { - Desenvolvimento } \\
\text { aplicativos e portais }\end{array}$ & Não se aplica \\
\hline
\end{tabular}




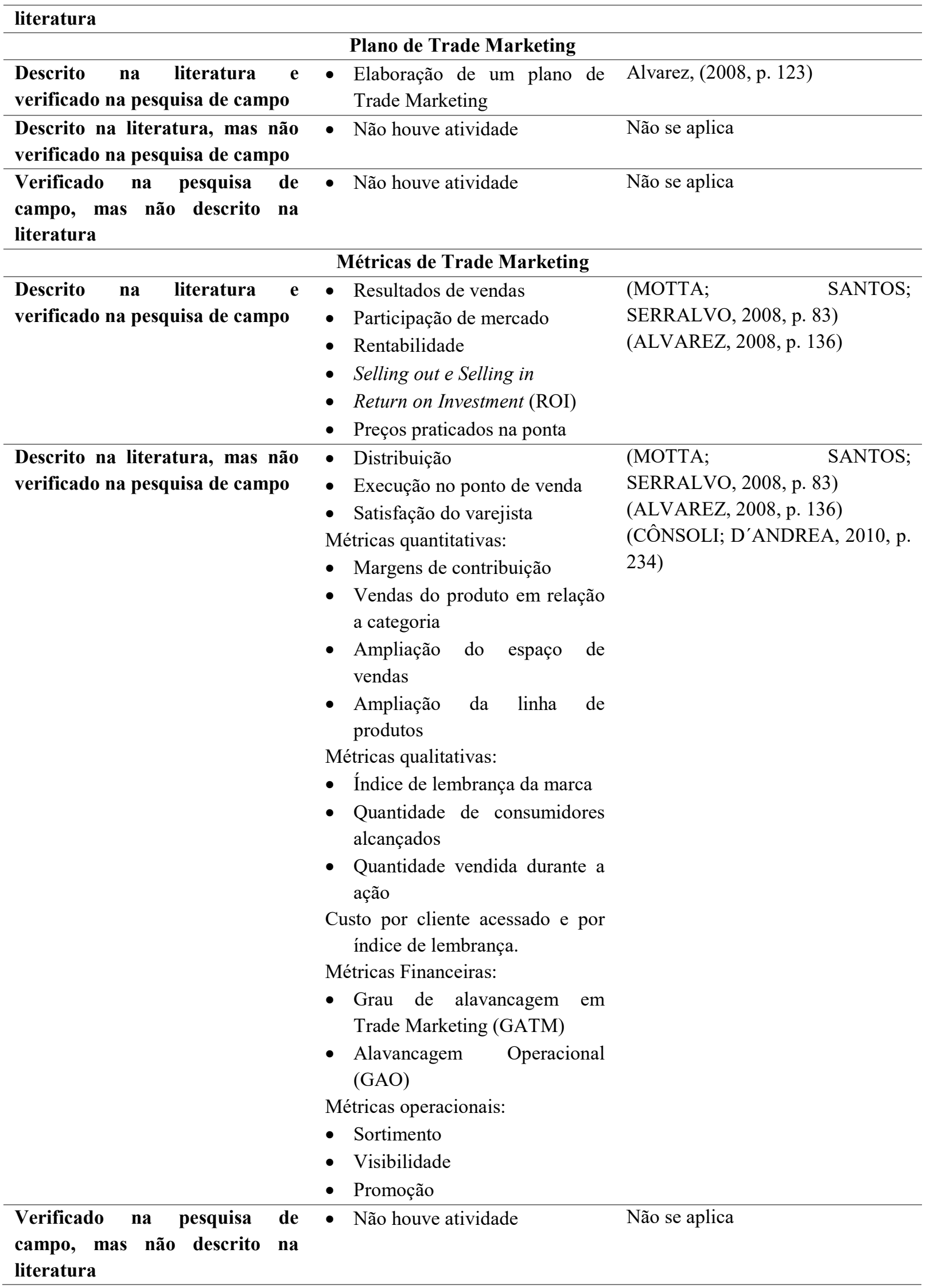

Fonte: elaborado pela autora com base na pesquisa de campo e literatura. 
A Tabela 4 apresenta as atividades de Trade Marketing desempenhadas pelas empresas pesquisadas.

Tabela 4 - Resumo dos principais achados do trabalho de campo.

\begin{tabular}{|c|c|c|c|c|c|}
\hline \multirow{2}{*}{$\begin{array}{l}\text { Atividades de } \\
\text { Trade } \\
\text { Marketing }\end{array}$} & \multicolumn{2}{|c|}{ EMS } & \multirow[t]{2}{*}{ Zambon } & \multirow[t]{2}{*}{ Biolab } & \multirow[t]{2}{*}{ Sandoz } \\
\hline & Marcas & Genérico & & & \\
\hline Segmentação & $\begin{array}{l}\text { Atratividade; } \\
\text { Região }\end{array}$ & $\begin{array}{l}\text { Atratividade; } \\
\text { Região }\end{array}$ & $\begin{array}{l}\text { A segmentação } \\
\text { não faz parte } \\
\text { das atividades } \\
\text { de } \quad \text { Trade } \\
\text { Marketing }\end{array}$ & $\begin{array}{l}\text { Organização; } \\
\text { Volume } \\
\text { compras }\end{array}$ & $\begin{array}{l}\text { Faturamento; } \\
\text { Região }\end{array}$ \\
\hline $\begin{array}{ll}\text { Sistema de } & \text { dnformação de } \\
\text { Trade } & \\
\text { Marketing } & \end{array}$ & $\begin{array}{l}\text { Análise de } \\
\text { dados de } \\
\text { fornecedores } \\
\text { externos; } \\
\text { Distribuição } \\
\text { das } \\
\text { informações } \\
\text { sobre o canal } \\
\text { para o } \\
\text { departamen- } \\
\text { to comercial. }\end{array}$ & $\begin{array}{l}\text { Análise de } \\
\text { dados de } \\
\text { fornecedores } \\
\text { externos; } \\
\text { Distribuição } \\
\text { das } \\
\text { informações } \\
\text { sobre o canal } \\
\text { para o } \\
\text { departamen- } \\
\text { to comercial. }\end{array}$ & $\begin{array}{l}\text { Análise de } \\
\text { dados de } \\
\text { fornecedores } \\
\text { externos; } \\
\text { Distribuição } \\
\text { das } \\
\text { informações } \\
\text { sobre o canal } \\
\text { para o } \\
\text { departamento } \\
\text { comercial; } \\
\text { Distribuição } \\
\text { das } \\
\text { informações } \\
\text { para } \\
\text { varejistas; } \\
\text { Coleta de } \\
\text { informações } \\
\text { sobre preço; de } \\
\text { Coleta } \\
\text { informação } \\
\text { sobre o preço } \\
\text { dos } \\
\text { concorrentes; } \\
\text { Pesquisas de } \\
\text { Trade } \\
\text { Marketing. }\end{array}$ & 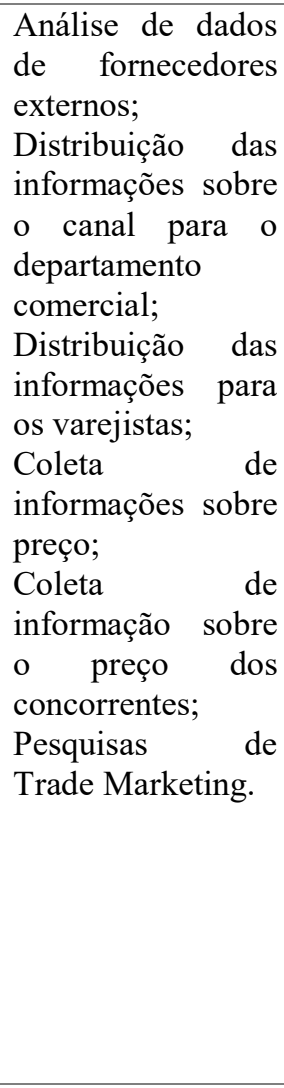 & 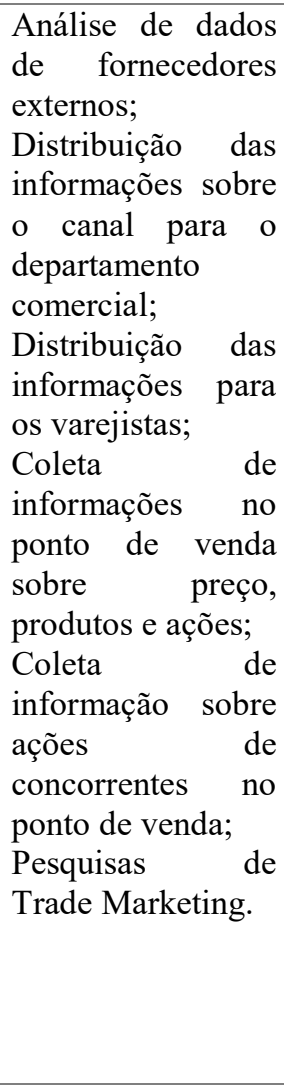 \\
\hline $\begin{array}{l}\text { Comportame- } \\
\text { nto do Shopper }\end{array}$ & $\begin{array}{ll}\text { Análise } & \text { da } \\
\text { decisão } & \text { de } \\
\text { compra } & \text { de } \\
\text { produtos. } & \end{array}$ & $\begin{array}{ll}\text { Análise } & \text { da } \\
\text { decisão } & \text { de } \\
\text { compra } & \text { de } \\
\text { produtos. } & \end{array}$ & $\begin{array}{l}\text { Solicitar, } \\
\text { analisar, } \\
\text { coordenar as } \\
\text { pesquisas sobre } \\
\text { comportamento } \\
\text { do shopper. }\end{array}$ & $\begin{array}{l}\text { Efetuar e analisar } \\
\text { a pesquisa de } \\
\text { comportamento do } \\
\text { shopper. }\end{array}$ & $\begin{array}{l}\text { Solicitar, analisar, } \\
\text { coordenar as } \\
\text { pesquisas sobre } \\
\text { comportamento do } \\
\text { shopper. }\end{array}$ \\
\hline Produto & $\begin{array}{l}\text { Avaliação de } \\
\text { concorrentes } \\
\text { quando } \\
\text { necessário; } \\
\text { Verificação } \\
\text { do } \\
\text { desempenho } \\
\text { da linha; } \\
\text { Adequação } \\
\text { do mix de } \\
\text { acordo com } \\
\text { o cliente; } \\
\text { Adequação }\end{array}$ & $\begin{array}{l}\text { Suporte ao } \\
\text { departamen- } \\
\text { to comercial; } \\
\text { Adequação } \\
\text { do mix de } \\
\text { acordo com } \\
\text { o cliente; } \\
\text { Adequação } \\
\text { da } \\
\text { embalagem } \\
\text { quando } \\
\text { necessário. }\end{array}$ & $\begin{array}{l}\text { Verificação do } \\
\text { desempenho da } \\
\text { linha de } \\
\text { produtos no } \\
\text { cliente; } \\
\text { Adequação do } \\
\text { mix de produto } \\
\text { de acordo com } \\
\text { o varejista. }\end{array}$ & 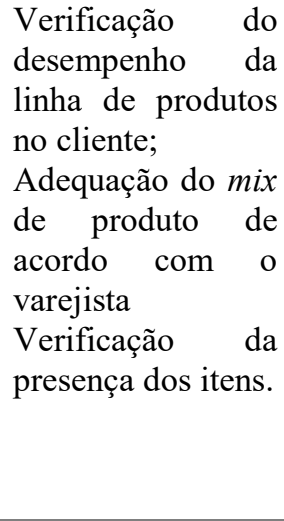 & $\begin{array}{lr}\text { Ações } & \text { para } \\
\text { divulgação } & \text { do } \\
\text { lançamento } & \text { de } \\
\text { produtos, } & \\
\text { Verificação } & \text { o } \\
\text { desempenho } & \text { da } \\
\text { linha; } & \\
\text { Verificação } & \text { a } \\
\text { presença dos } & \text { itens; } \\
\text { Sugestão } & \text { de } \\
\text { ampliação } & \text { da } \\
\text { linha; } & \\
\text { Adequação do } & \text { mix }\end{array}$ \\
\hline
\end{tabular}




\begin{tabular}{|c|c|c|c|c|c|}
\hline & $\begin{array}{l}\text { da } \\
\text { embalagem } \\
\text { quando } \\
\text { necessário. }\end{array}$ & & & & $\begin{array}{l}\text { de acordo com o } \\
\text { cliente. }\end{array}$ \\
\hline Preço & $\begin{array}{l}\text { Acompanha } \\
\text { preços } \\
\text { praticados } \\
\text { pelos } \\
\text { varejistas; } \\
\text { Acompanha } \\
\text { preço de } \\
\text { produtos } \\
\text { concorrentes } \\
\text { praticados } \\
\text { pelos } \\
\text { varejistas; } \\
\text { Evita } \\
\text { conflito de } \\
\text { canais; } \\
\text { Orienta o } \\
\text { varejista } \\
\text { quando há } \\
\text { inadequação } \\
\text { na faixa de } \\
\text { preço } \\
\text { desejada. }\end{array}$ & $\begin{array}{l}\text { Acompanha } \\
\text { preços } \\
\text { praticados } \\
\text { pelos } \\
\text { varejistas; } \\
\text { Acompanha } \\
\text { preço de } \\
\text { produtos } \\
\text { concorrentes } \\
\text { praticados } \\
\text { pelos } \\
\text { varejistas; } \\
\text { Evita } \\
\text { conflito de } \\
\text { canais; } \\
\text { Orienta o } \\
\text { varejista } \\
\text { quando há } \\
\text { inadequação } \\
\text { na faixa de } \\
\text { preço } \\
\text { desejada. }\end{array}$ & $\begin{array}{l}\text { Acompanha } \\
\text { preços } \\
\text { praticados } \\
\text { pelos } \\
\text { varejistas; } \\
\text { Acompanha } \\
\text { preço de } \\
\text { produtos } \\
\text { concorrentes } \\
\text { praticados } \\
\text { pelos varejistas }\end{array}$ & $\begin{array}{l}\text { Acompanha } \\
\text { preços praticados } \\
\text { pelos varejistas; } \\
\text { Acompanha preço } \\
\text { de produtos } \\
\text { concorrentes } \\
\text { praticados pelos } \\
\text { varejistas }\end{array}$ & $\begin{array}{l}\text { Participa na } \\
\text { formação do } \\
\text { preço; } \\
\text { Acompanha } \\
\text { preços praticados } \\
\text { pelos varejistas } \\
\text { Acompanha preço } \\
\text { de produtos } \\
\text { concorrentes } \\
\text { praticados pelos } \\
\text { varejistas; } \\
\text { Evita conflito de } \\
\text { canais; } \\
\text { Orienta o varejista } \\
\text { quando há } \\
\text { inadequação na } \\
\text { faixa de preço } \\
\text { desejada. }\end{array}$ \\
\hline Comunicação & $\begin{array}{l}\text { Promoção de } \\
\text { vendas } \\
\text { (brindes } \\
\text { somente } \\
\text { para } \\
\text { canal); } \\
\text { Merchandi- } \\
\text { sing; } \\
\text { Materiais de } \\
\text { PDV; } \\
\text { Ações } \\
\text { cooperadas } \\
\text { (tabloides); } \\
\text { Eventos } \\
\text { (feiras e } \\
\text { congressos); } \\
\text { Auxilia o } \\
\text { departamen- } \\
\text { to comercial } \\
\text { na } \\
\text { negociação } \\
\text { de espaços } \\
\text { com o } \\
\text { varejista; } \\
\text { Fiscaliza as } \\
\text { ações } \\
\text { negociadas. }\end{array}$ & $\begin{array}{l}\text { Promoção de } \\
\text { vendas } \\
\text { (brindes } \\
\text { somente para } \\
\text { o canal); } \\
\text { Merchandi- } \\
\text { sing; } \\
\text { Materiais de } \\
\text { PDV; } \\
\text { Ações } \\
\text { cooperadas } \\
\text { (tabloides); } \\
\text { Eventos } \\
\text { (feiras e } \\
\text { congressos); } \\
\text { Auxilia o } \\
\text { departamen- } \\
\text { to comercial } \\
\text { na } \\
\text { negociação } \\
\text { de espaços } \\
\text { com o } \\
\text { varejista; } \\
\text { Fiscaliza as } \\
\text { ações } \\
\text { negociadas. }\end{array}$ & $\begin{array}{l}\text { Promoção de } \\
\text { vendas } \\
\text { (brindes } \\
\text { somente para o } \\
\text { canal); } \\
\text { Merchandising; } \\
\text { Materiais de } \\
\text { PDV; } \\
\text { Ações } \\
\text { cooperadas } \\
\text { (tabloides); } \\
\text { Eventos (feiras } \\
\text { e congressos); } \\
\text { Auxilia o } \\
\text { departamento } \\
\text { comercial na } \\
\text { negociação de } \\
\text { espaços com o } \\
\text { varejista; } \\
\text { Fiscaliza as } \\
\text { ações } \\
\text { negociadas. }\end{array}$ & 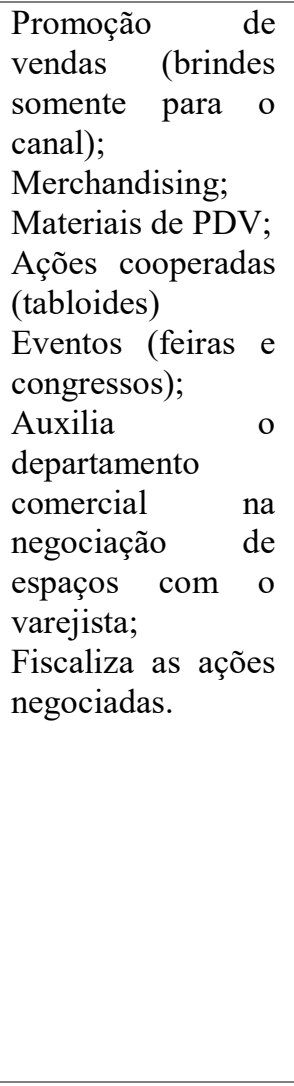 & 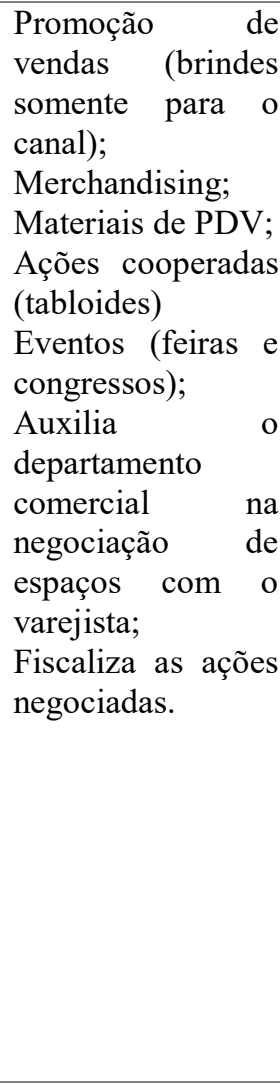 \\
\hline $\begin{array}{l}\text { Gerenciamen- } \\
\text { to de } \\
\text { Categorias }\end{array}$ & $\begin{array}{l}\text { Não } \\
\text { desenvolvem } \\
\text { atividades } \\
\text { em relação a } \\
\text { gerenciame- } \\
\text { nto de } \\
\text { categorias. }\end{array}$ & $\begin{array}{l}\text { Auxilia } \quad \text { o } \\
\text { varejista na } \\
\text { formação de } \\
\text { categorias; } \\
\text { Avalia o } \\
\text { desempenho } \\
\text { das }\end{array}$ & $\begin{array}{l}\text { Não } \\
\text { desenvolvem } \\
\text { atividades em } \\
\text { relação a a } \\
\text { gerenciamento } \\
\text { de categorias. }\end{array}$ & \begin{tabular}{lr}
\multicolumn{3}{c}{ Auxilia o varejista } \\
na formação de \\
categorias; \\
Avalia \\
desempenho da \\
categoria \\
dermocosméticos;
\end{tabular} & $\begin{array}{l}\text { Auxilia o varejista } \\
\text { na formação de } \\
\text { categorias; } \\
\text { Avalia } \\
\text { desempenho das } \\
\text { categorias. }\end{array}$ \\
\hline
\end{tabular}




\begin{tabular}{|c|c|c|c|c|c|}
\hline & & categorias. & & $\begin{array}{l}\text { Tem planograma } \\
\text { para a categoria de } \\
\text { dermocosméticos. }\end{array}$ & \\
\hline $\begin{array}{l}\text { Relacioname- } \\
\text { nto com o } \\
\text { canal }\end{array}$ & $\begin{array}{l}\text { Treinamen- } \\
\text { tos para a } \\
\text { equipe de } \\
\text { vendas do } \\
\text { canal; } \\
\text { Desenvolvi- } \\
\text { mento de } \\
\text { aplicativos e } \\
\text { portais }\end{array}$ & $\begin{array}{l}\text { Treinamen- } \\
\text { tos para a } \\
\text { equipe de } \\
\text { vendas do } \\
\text { canal; } \\
\text { Desenvolvi- } \\
\text { mento de } \\
\text { aplicativos e } \\
\text { portais. }\end{array}$ & $\begin{array}{l}\text { Treinamentos } \\
\text { para a equipe } \\
\text { de vendas do } \\
\text { canal. }\end{array}$ & $\begin{array}{l}\text { Treinamentos para } \\
\text { a equipe de vendas } \\
\text { do canal. }\end{array}$ & $\begin{array}{l}\text { Treinamentos para } \\
\text { a equipe de vendas } \\
\text { do canal; } \\
\text { Desenvolvimento } \\
\text { de portais; } \\
\text { Programa re de } \\
\text { suporte para } \\
\text { melhorias nas } \\
\text { operações ro } \\
\text { canal; } \\
\begin{array}{l}\text { Compartilhamento } \\
\text { de informações. }\end{array}\end{array}$ \\
\hline $\begin{array}{ll}\text { Plano de } \\
\text { Trade } \\
\text { Marketing }\end{array}$ & $\begin{array}{l}\text { Apresenta- } \\
\text { ção que } \\
\text { contempla } \\
\text { metas, } \\
\text { cronograma } \\
\text { e programa } \\
\text { de ação; } \\
\text { O orçamento } \\
\text { de Trade } \\
\text { Marketing } \\
\text { está inserido } \\
\text { no } \\
\text { orçamento } \\
\text { de } \\
\text { marketing; } \\
\text { As ações são } \\
\text { feitas de } \\
\text { acordo com } \\
\text { a demanda. }\end{array}$ & $\begin{array}{l}\text { Apresenta- } \\
\text { ção que } \\
\text { contempla } \\
\text { metas, } \\
\text { cronograma } \\
\text { e programa } \\
\text { de ação; } \\
\text { Orçamento } \\
\text { próprio. }\end{array}$ & $\begin{array}{lr}\text { Há um plano } \\
\text { de } & \text { Trade } \\
\text { Marketing } & \text { que } \\
\text { descreve } & \text { o } \\
\text { momento atual } \\
\text { em que a } \\
\text { marca } & \text { se } \\
\text { encontra, os } \\
\text { objetivos r e } \\
\text { calendário de } \\
\text { ações } \\
\text { promocionais }\end{array}$ & $\begin{array}{l}\text { Plano de Trade } \\
\text { Marketing anual; } \\
\text { Plano em conjunto } \\
\text { com os canais; } \\
\text { Orçamento por } \\
\text { demanda. }\end{array}$ & $\begin{array}{l}\text { Plano de Trade } \\
\text { Marketing está } \\
\text { contido no plano } \\
\text { de marketing; } \\
\text { Efetuado } \\
\text { anualmente; } \\
\text { Especificadas as } \\
\text { ações em cada tipo } \\
\text { de canal; } \\
\text { Apresentação do } \\
\text { plano regional e } \\
\text { global; } \\
\text { Compartilham o } \\
\text { plano com os } \\
\text { principais clientes; } \\
\text { Os principais } \\
\text { clientes } \\
\text { compartilham seus } \\
\text { planos com a } \\
\text { empresa; } \\
\text { Orçamento } \\
\text { independente, por } \\
\text { área. }\end{array}$ \\
\hline $\begin{array}{ll}\text { Métricas de } \\
\text { Trade } \\
\text { Marketing }\end{array}$ & $\begin{array}{l}\text { Resultados } \\
\text { de vendas; } \\
\text { Participação } \\
\text { de mercado; } \\
\text { Rentabilida- } \\
\text { de; } \\
\text { Selling out e } \\
\text { Selling in; } \\
\text { Return on } \\
\text { Investment } \\
\text { (ROI). }\end{array}$ & $\begin{array}{l}\text { Resultados } \\
\text { de vendas; } \\
\text { Participação } \\
\text { de mercado; } \\
\text { Rentabilida- } \\
\text { de; } \\
\text { Selling out e } \\
\text { Selling in; } \\
\text { Return on } \\
\text { Investment } \\
\text { (ROI). }\end{array}$ & $\begin{array}{l}\text { Resultados de } \\
\text { vendas; } \\
\text { Participação de } \\
\text { mercado; } \\
\text { Rentabilidade; } \\
\text { Selling out e } \\
\text { Selling in; } \\
\text { Return on } \\
\text { Investment } \\
\text { (ROI); } \\
\text { Preços } \\
\text { praticados na } \\
\text { ponta. }\end{array}$ & $\begin{array}{l}\text { Resultados de } \\
\text { vendas; } \\
\text { Participação de } \\
\text { mercado; } \\
\text { Rentabilidade; } \\
\text { Selling out e } \\
\text { Selling in; } \\
\text { Return } \\
\text { Investment (ROI); } \\
\text { Preços praticados } \\
\text { na ponta. }\end{array}$ & $\begin{array}{l}\text { Resultados } \\
\text { vendas; } \\
\text { Participação de } \\
\text { mercado; } \\
\text { Rentabilidade; } \\
\text { Selling out e } \\
\text { Selling in; } \\
\text { Return on } \\
\text { Investment (ROI); } \\
\text { Preços praticados } \\
\text { na ponta. }\end{array}$ \\
\hline
\end{tabular}

Fonte: elaborada pela autora com base na pesquisa de campo. 


\section{CONSIDERAÇÕES FINAIS}

O Trade Marketing desempenha atividades que, originalmente, pertencem ao marketing. Entretanto, nas empresas os departamentos de marketing não absorveram estas funções. Portanto, houve a necessidade da criação de um departamento que fosse responsável pela gestão dos canais de distribuição, os departamentos de Trade Marketing.

O Trade Marketing consiste em um conjunto de atividades, ações e ferramentas utilizadas pelas empresas para melhorar as relações e as operações de seus canais, obtendo, assim, uma força sinérgica e criando valor na cadeia de distribuição. Por isso, os canais devem ser vistos como clientes. Por meio do Trade Marketing é possível que a empresa melhore sua rentabilidade por clientes, utilizando ferramentas que permitam otimizar o giro dos produtos no ponto de venda.

De forma geral, o Trade Marketing é visto nas empresas como um elo entre os departamentos de marketing e comercial. Há um grande foco em alimentar os departamentos com informações, mas os canais de distribuição ainda são menosprezados nesta visão. Os departamentos de Trade Marketing deveriam existir para ser um elo entre a cadeia de distribuição e não um elo entre dois departamentos da empresa.

Pode-se perceber que quanto maior a concorrência no PDV, maior a necessidade de atividades de Trade Marketing. O setor farmacêutico é um setor extremamente dinâmico, em que muitas mudanças ocorrem em um curto período de tempo. Nota-se que alguns fatores tornam o Trade Marketing importante no setor farmacêutico, como o poder do farmacêutico para decisão de marca do produto e os impedimentos legais em relação a comunicação com o consumidor final.

As principais atividades desenvolvidas pelo Trade Marketing são segmentar os canais de distribuição, alimentar e analisar o sistema de informação de Trade Marketing, entender o comportamento dos shoppers, auxiliar em atividades relativas a produto, preço e comunicação, ajudar o varejista no gerenciamento de categorias, estabelecer o relacionamento com os canais de distribuição, elaborar o plano de trade marketing e definir métricas para acompanhamento das ações de Trade Marketing. As atividades que podem ser desenvolvidas pelo Trade Marketing estão relacionadas no Quadro 33. 
Quadro 33 - Resumo das atividades que podem ser desenvolvidas pelo Trade Marketing

\begin{tabular}{|c|c|}
\hline Atividades de Trade Marketing & Descrição das atividades \\
\hline Segmentação & $\begin{array}{l}\text { Definir critérios e efetuar a segmentação dos canais de distribuição } \\
\text { Verificar potencial de compra } \\
\text { Verificar rentabilidade dos clientes }\end{array}$ \\
\hline $\begin{array}{l}\text { Sistema de Informação de Trade } \\
\text { Marketing }\end{array}$ & $\begin{array}{l}\text { Análise de dados de fornecedores externos } \\
\text { Distribuição das informações sobre o canal para o departamento } \\
\text { comercial } \\
\text { Distribuição das informações para os varejistas } \\
\text { Coleta de informações no ponto de venda sobre preço, produtos e ações } \\
\text { Coleta de informação sobre ações de concorrentes no ponto de venda } \\
\text { Pesquisas de Trade Marketing }\end{array}$ \\
\hline Comportamento do shopper & $\begin{array}{l}\text { Obter dados sobre o comportamento do shopper } \\
\text { Efetuar a análise do comportamento do shopper } \\
\text { Distribuir informações sobre o comportamento do shopper }\end{array}$ \\
\hline Produto & $\begin{array}{l}\text { Verificar a atratividade da embalagem e performance no PDV } \\
\text { Verificar as embalagens danificadas no PDV } \\
\text { Ações de lançamento de produtos com os principais clientes } \\
\text { Monitorar concorrente: lançamento de produtos e participação do } \\
\text { concorrente no mix dos clientes. } \\
\text { Verificar o desempenho da linha de produto } \\
\text { Sugerir ampliação de linha de produtos } \\
\text { Orientar o varejista sobre o mix e volume de acordo com o perfil do } \\
\text { consumidor } \\
\text { Verificar presença, volume de estoque e rupturas no varejista }\end{array}$ \\
\hline Preço & $\begin{array}{l}\text { Monitorar os preços praticados pelos canais de distribuição } \\
\text { Acompanhar os preços dos produtos concorrentes praticados pelos canais } \\
\text { de distribuição } \\
\text { Acompanhar as margens e giro } \\
\text { Evitar o conflito entre os canais } \\
\text { Orientar o varejista quando houver inadequações quanto ao preço ao } \\
\text { consumidor (maior ou menor que o desejado) } \\
\text { Participar da formação de preços }\end{array}$ \\
\hline Comunicação & $\begin{array}{l}\text { Merchandising } \\
\text { Comunicação no PDV } \\
\text { Negociação de espaços } \\
\text { Fiscalização de espaços negociados } \\
\text { Decisão sobre quais eventos participar } \\
\text { Presença no evento para se relacionar com os canais }\end{array}$ \\
\hline Gerenciamento por Categorias & $\begin{array}{l}\text { Auxiliar no gerenciamento por categorias } \\
\text { Sinalizar o capitão da categoria } \\
\text { Mostrar a importância e como funciona o gerenciamento por categorias } \\
\text { para o varejista }\end{array}$ \\
\hline Relacionamento com o canal & $\begin{array}{l}\text { Treinamento } \\
\text { Desenvolvimento de portais e aplicativos para o canal }\end{array}$ \\
\hline Plano de Trade Marketing & Elaboração do Plano de Trade Marketing \\
\hline Métricas de Trade Marketing & $\begin{array}{l}\text { Determinar quais as métricas serão utilizadas } \\
\text { Acompanhar as métricas estabelecidas }\end{array}$ \\
\hline
\end{tabular}

Fonte: elaborado pela autora

As limitações da pesquisa são principalmente as que se referem ao método escolhido. Por tratar-se de um estudo exploratório não há possibilidade de inferir os resultados obtidos nas empresas pesquisada para o universo. Contudo, houve o cuidado em estabelecer um protocolo para minimizar o viés da pesquisa e também atender aos critérios apresentados por 
Brown; Dant, (2008): objetividade, replicabilidade, competência, inteligibilidade, eficiência e importância.

Dentre as contribuições para a literatura, este estudo aprofundou o conhecimento sobre o Trade Marketing. Preenche ainda a lacuna sobre as atividades desenvolvidas pelo Trade Marketing no setor farmacêutico, de forma exploratória. Aponta também as suas especificidades. Já como contribuições gerenciais a presente dissertação pode auxiliar as empresas na implantação de uma estrutura de Trade Marketing ou ainda definir as atividades que podem ser desempenhadas por este departamento.

A partir desta dissertação podem ser desenvolvidos estudos futuros aprofundando o conhecimento sobre Trade Marketing. Pesquisas de caráter conclusivos podem ser efetuadas com base nas atividades de Trade Marketing levantadas. A visão do varejista sobre as atividades desenvolvidas pelas indústrias pode ser alvo de estudos futuros, assim como a visão dos atacadistas sobre estas atividades. 


\section{REFERÊNCIAS BIBLIOGRÁFICAS}

ACHROL, R. Evolution of the marketing organization: new forms for turbulent environments. The Journal of Marketing, v. 55, n. 4, p. 77-93, 1991.

ACHROL, R.; REVE, T.; STERN, L. W. The environment of marketing channel dyads: a framework for comparative analysis. The Journal of Marketing, v. 47, n. 4, p. 55-67, 1983.

ALMEIDA, V. M. C.; SIANO, P. L.; FREITAS, G. F.; D'AlBERGARIA, F. Trade Marketing no Setor de Lojas de Conveniência. Revista de Administração de Empresas, v. 52, n. nov./dez, p. 643-656, 2012.

ALVAREZ, F. J. S. M. A aplicação dos conceitos de Trade Marketing nas empresas de produtos alimentícios de consumo: um estudo exploratório. 1999. 120f. Dissertação (Mestrado em Administração). Universidade de São Paulo - USP, São Paulo, 1999.

ALVAREZ, F. J. S. M. O modelo de gerência de contas especiais: um estudo exploratório em instituições financeiras no Brasil. 2004. 212 f. Tese (Doutorado em Administração). Universidade de São Paulo - USp, São Paulo, 2004.

ALVAREZ, F. J. S. M. Trade Marketing: a conquista do consumidor no ponto de venda. 1. ed. São Paulo: Saraiva, 2008.

AlvarEZ, F. M.; TOLEDO, L. A.; CAIGAWA, S. M.; JORDÃO, T. R. Trade Marketing. Um estudo exploratório junto a empresas de produtos alimentícios. Congresso Virtual Brasileiro de Administração, 2004.

AMERICAN MARKETING ASSOCIATION. Marketing definition. Disponível em: $<$ https://www.ama.org/AboutAMA/Pages/Definition-of-Marketing.aspx>. Acesso em: 22 set. 2014.

AMERICAN MARKETING ASSOCIATION. American Marketing Association. Disponível em: $<$ https://www.ama.org/Pages/default.aspx>. Acesso em: 6 jun. 2015.

AMES, C. Dilemma of product/market management. Harvard Business Review, 1971.

ANDERSON, J. C.; NARUS, J. A. A Model of the Distributor's Perspective of Manufacturer Working. Journal of Marketing, v. 48, n. Fall, p. 62-74, 1984.

ANVISA. A Agência. Disponível em: $<$ http://portal.anvisa.gov.br/wps/portal/anvisa/anvisa/agencia $>$. Acesso em: 7 jun. 2015.

ASSIS, E. E.; MAZZARO, D.; VANCIN, P.; PRADO, K. P. L. A. Ferramentas e funções do trade marketing no século XXI: estudo de caso da Tresemmé no Brasil. FACEF Pesquisa: Desenvolvimento e Gestão, v. 16, n. 3, p. 313-327, 2013.

ASSOCIAÇÃO BRASILEIRA DE ANUNCIANTES. Glossário de Promoção e Merchandising. Disponível em: $\quad<$ http://www.aba.com.br/canais/trade-e-shopper- 
marketing/documentos/glossario-de-termos-usados-em-promocao-e-trade-marketing>. Acesso em: 7 jun. 2015.

BIOLAB. Sitio Eletrônico da Organização. Disponível em: $<$ http://www.biolabfarma.com.br/>. Acesso em: 1 maio. 2015.

BLESSA, R. Merchandising farma: a farmácia do futuro. 2. ed. São Paulo: Cengage Learning, 2008.

BRASIL. Lei $\mathrm{n}^{0} 5.991$ de 17 de dezembro de 1973. Dispõe sobre o controle sanitário do comércio de drogas, medicamentos, insumos farmacêuticos e correlatos, e dá outras providências . Brasilia, DF, 1973.

BRASIL. Lei no 9.787, de 10 de fevereiro de 1999. Altera a Lei ${ }^{\circ} 6.360$, de 23 de setembro de 1976, que dispõe sobre a vigilância sanitária, estabelece o medicamento genérico, dispõe sobre a utilização de nomes genéricos em produtos farmacêuticos e dá outras providências. Brasilia, DF, 1999.

BRASIL. Agência Nacional de Vigilância Sanitária. Resolução - RDC No 134, de 29 de maio de 2003. Dispõe sobre a adequação dos medicamentos já registrados. Brasilia, DF 2003.

BRASIL. Agência Nacional de Vigilância Sanitária. Resolução - RDC 96 de 17 de dezembro de 2008. Dispõe sobre a propaganda, publicidade, informação e outras práticas cujo objetivo seja a divulgação ou promoção comercial de medicamentos Brasilia, DF 2008.

BRASIL. (Da Comissão de Legislação Participativa). Projeto de Lei No 5451, Regulamenta as profissões dePromotor de Vendas e de Demonstrador de Mercadorias, Brasilia, DF,2009a.

BRASIL. Agência Nacional de Vigilância Sanitária. Resolução - RDC no 44 de 17 de agosto de 2009. Dispõe sobre Boas Práticas Farmacêuticas para o controle sanitário do funcionamento, da dispensação e da comercialização de produtos e da prestação de serviços farmacêuticos em farmácias e drogarias e dá outras providências., Brasilia, DF, 2009b.

BRASIL. Tribunal Superior do Trabalho. Súmula no 331, Contrato de Prestação de Serviços. Legalidade Resolução 174/2011, divulgado em 27, 30 e 31 de maio de 2011.

BRASIL. Agência Nacional de Vigilância Sanitária. Resolução - RDC no 58 de 10 de outubro de 2014. Dispõe sobre as medidas a serem adotadas junto à Anvisa pelos titulares de registro de medicamentos para a intercambialidade de medicamentos similares com o medicamento de referência. Brasilia, DF, 2014

BROWN, J. R.; DANT, R. On what makes a significant contribution to the retailing literature. Journal of Retailing, v. 84, n. 2, p. 131-135, jun. 2008.

CABELlO, T. C.; CAMACHO, M. Á. R.; VÁZQUEZ, M. V. The relationship between organizational structure and market orientation: An empirical aproach. The International Journal of Management Science and information Technology, v. Jan-Mar, n. 11, p. 1-48, 2014. 
CAMPOMAR, M. C. O Sistema de Marketing. Revista Marketing, v. 18, n. 131, p. 43-45, 1984.

CAMPOMAR, M. C. Do uso de "estudo de caso" em pesquisas para dissertações e teses em administração. Revista de Administração, São Paulo, v. 26, n. 3, p. 95-97, 1991.

CAMPOMAR, M. C. Notas de Aula São Paulo, 2013.

CAMPOMAR, M. C.; IKEDA, A. A. O planejamento de marketing e a confecção de planos: dos conceitos a um novo modelo. 1. ed. São Paulo: Saraiva, 2006.

CHAMIE, B. C. Valor para o shopper na experiência de compra de brinquedos. 2012. 240f. Dissertação (Mestrado em Administração). Universidade de São Paulo - USP, São Paulo, 2012.

CHIUSOLI, C. L. Um estudo exploratório sobre tipologia e sistema de informação de marketing. 2005. 253f. Dissertação (Mestrado em Administração). Universidade de São Paulo - USP, São Paulo, 2005.

CONSELHO FEDERAL DE FARMÁCIA. Relatório da Comissão de Fiscalização, 2010.

CÔNSOLI, M. A.; D'ANDREA, R. Trade Marketing: estratégias de distribuição e execução de vendas. 1. ed. São Paulo: Atlas, 2010.

CORSTJENS, J.; CORSTJENS, M. Store Wars: the battle for mindspace and shelfspace. 1. ed. Chichester: Wiley, 1995.

COUGHLAN, A. T. et al. Canais de Marketing e Distribuição. 6. ed. Porto Alegre: Bookman, 2002.

CREMESP. Conselho Regional de Medicina do estado de São Paulo. Disponível em: $<$ http://www.cremesp.org.br/?siteAcao=Publicacoes\&acao=detalhes_capitulos\&cod_capitulo $=64>$. Acesso em: 30 maio. 2013.

CRESCITELli, E.; CAMPOMAR, M. C.; GIL, C. Product placement, merchandising e outras considerações. In: Administração de Marketing. 14. ed. São Paulo: Pearson Education do Brasil, 2012.

CRESCITELLI, E.; SHIMP, T. A. Comunicação de Marketing: integrando propaganda, promoção e outras formas de divulgação. 1. ed. São Paulo: Cengage Learning, 2012.

CRUZATO, A. P. Ana Paula Cruzato: depoimento [ 10 de abril de 2015]. Entrevistador: Tatiana Ferrara Barros. São Paulo: Biolab, 2015. Arquivo sonoro em formato eletrônico. Entrevista realizada na seda da Biolab.

DAVIES, G. Marketing to retailers: a battle for distribution? Long Range Planning, v. 23, n. 6, p. 101-108, 1990.

DAWSON, J.; SHAW, S. The move to administered vertical marketing systems by British retailers. European Journal of Marketing, v. 23, n. 7, p. 42-52, 1989. 
DEWSNAP, B.; JOBBER, D. An exploratory study of sales-marketing integrative devices. European Journal of Marketing, v. 43, n. 7/8, p. 985-1007, 2009.

DHAR, S. K.; HOCH, S. J.; KUMAR, N. Effective category management depends on the role of the category. Journal of Retailing. v. 77, p. 165-184, 2001.

DIAS, C.; ROMANO-LIEBER, N. Processo da implantação da política de medicamentos genéricos no Brasil. Cadernos de Saúde Pública, v. 22, n. 8, p. 1661-1669, 2006.

DUPUIS, M.; TISSIER-DESBORDES, E. Trade Marketing: mode ou nouvelle approche des relations producteurs/distributeurs? Décisions Marketing, n. 2, p. 45-57, 1994.

DUPUIS, M.; TISSIER-DESBORDES, E. Trade marketing and retailing: a European approach. Journal of Retailing and Consumer Services, v. 3, n. 1, p. 43-51, 1996.

DUTRA, J. Alteração no Modelo de GestãoFiaSão PauloFIA, , 2014. Disponível em: $<$ http://www.fia.com.br/Podcasts/podcastfia_joel_dutra_gestao_de_pessoas_30_05_14.mp3>

EISENHARDT, K. M.; GRAEBNER, M. E. Theory Building From Cases: Opportunities and Challenges. Academy of Management Journal, v. 50, n. 1, p. 25-32, 1 fev. 2007.

ELIASHBERG, J.; MICHIE, D. Multiple business goals sets as determinants of marketing channel conflict: An empirical study. Journal of Marketing Research, v. 21, n. 1, p. 75-88, 1984.

EMS. Mais Saúde. Escritório Digital, 2014. Aplicativo. Acesso em: 13 de maio de 2015.

EMS. Sítio da organização. Disponível em: <http://www.ems.com.br/web/guest/home>. Acesso em: 13 maio. 2015a.

EMS. Kairos. Noritel S.A., 2015b. Aplicativo. Acesso em: 13 de maio de 2015.

EMS GENÉRICOS. Sítio da divisão Genéricos. Disponível em: $<\mathrm{http}$ ://www.emsgenericos.com.br/2015/>. Acesso em: 13 maio. 2015a.

EMS GENÉRICOS. Sítio do portal de treinamentos dos módulos Em Foco. Disponível em: <http://antimicrobianoemfoco.com.br/plataforma/>. Acesso em: 12 maio. 2015b.

EMS MARCAS. Sítio dos medicamentos equivalêntes. Disponível em: $<$ http://www.equivalentesems.com.br/>. Acesso em: 14 maio. 2015.

ENGEL, J. F.; BLACKWELL, R. D.; MINIARD, P. W. Consumer Behavior. Hinsdale: Dryden Press, 2011.

FERRACCIÙ, J. D. S. S. Marketing Promocional: a evolução da promoção de vendas. 6. ed. São Paulo: Pearson Prentice Hall, 2007.

FLICK, U. Introdução à pesquisa qualitativa. 3. ed. Porto Alegre: Artmed, 2009. 
GEYSKENS, I.; STEENKAMP, J.; KUMAR, N. A meta-analysis of satisfaction in marketing channel relationships. Journal of Marketing Research, v. 36, n. 2, p. 223-238, 1999.

GODOY, A. S. Pesquisa qualitativa: tipos fundamentais. Revista de administração de empresas, 1995.

HUERTAS, M. K. Z. Atitude do consumidor frente à propaganda: um estudo sobre os apelos racionais e emocionais da propaganda na indústria farmacêutica. 2005. 367f. Tese (Doutorado em Administração). Universidade de São Paulo - USP, São Paulo, 2005.

IMS HEALTH. Relatório IMS, 2014.

INTERFARMA. Guia 2014 Interfarma. São Paulo, 2014.

KOTLER, P.; KELlER, K. L. Administração de marketing. 12. ed. São Paulo: Pearson Education do Brasil, 2006.

KROHN, M.; KLEBER, A.; SCHAFFAR, G. Now we are talking sense! Functional approaches to novel nutraceuticals and cosmeceuticals. Biotechnology Journal, v. 3, p. 1147-1156, 2008.

LONGARAY, A. A.; ENSSLIN, L. Use of Multi-Criteria Decision Aid to Evaluate the Performance of Trade Marketing Activities of a Brazilian Industry. Management and Organizational Studies, v. 2, n. 2, 2015.

MAZZERO, S. Métricas para o accountability em marketing: uma análise em empresas da indústria farmacêutica. 2014. 228f. Dissertação (Mestrado em Administração) Universidade de São Paulo- USP, São Paulo, 2014.

MCCARTHY, J. E. Marketing básico: uma visão gerencial. 1. ed. Rio de Janeiro: Zahar, 1976.

MENTZER, J.; MIN, S.; ZACHARIA, Z. The nature of interfirm partnering in supply chain management. Journal of Retailing, v. 76, n. 4, p. 549-568, 2000.

MICHAELIS. Dicionário Michaelis. Disponível $<\mathrm{http}$ ://michaelis.uol.com.br/moderno/ingles/index.php?lingua=inglesportugues\&palavra=shopper $>$. Acesso em: 30 jul. 2014.

MOTTA, R. Estratégias e estruturas de trade marketing na indústria de bens de consumo não-duráveis como resposta as transformações ocorridas no varejo alimentício do Brasil. 2007. 125f. Dissertação (Mestrado em Administração)Pontifícia Universidade Católica de São Paulo, 2007.

MOTTA, R.; SANTOS, N.; SERRALVO, F. A. Trade Marketing: teoria e prática para gerenciar os canais de distribuição. 1. ed. Rio de Janeiro: [s.n.].

NEFF, J. It's the end of "Marketing" as know it at Procter \& Gamble. Disponível em: $<$ http://adage.com/article/cmo-strategy/end-marketing-procter-gamble/293918/>. Acesso em: 17 jul. 2014. 
NETO, J. O. C. A. José Octávio Auler Neto: depoimento [29 de abril de 2015] Entrevistador: Tatiana Ferrara Barros. Hortolândia: EMS, 2015. Arquivo sonoro em formato eletrônico. Entrevista realizada na seda da EMS.

NETO, N. DE B. E S.; MACEDO-SOARES, T. D. L. VAN A. DE; PITASSI, C. Adequação estratégica das áreas de trade marketing das empresas de bens de consumo atuando no Brasil. Revista ADM.MADE, v. 15, n. 1, p. 1-22, 2011.

NOVARTIS. Sitio da Novartis no Brasil. Disponível em: <http://www.novartis.com.br/ >. Acesso em: 21 maio. 2015.

OSAKI, F. Flávia Osaki: depoimento [19 de maio de 2015] Entrevistador: Tatiana Ferrara Barros. São Paulo: Sandoz, 2015. Arquivo sonoro em formato eletrônico. Entrevista realizada na seda da Sandoz.

PALUDETTI. O que significa Rx ? Disponível em: $<$ https://memoriadapharmacia.wordpress.com/2010/07/20/o-que-significa-rx/>. Acesso em: 11 jun. 2015.

PAMPlONA, D. T. D. A. Diego Tognonato D'Albergaria Pamplona: depoimento [29 de abril de 2015] Entrevistador: Tatiana Ferrara Barros. Hortolândia: EMS, 2015. Arquivo sonoro em formato eletrônico. Entrevista realizada na seda da EMS..

PARENTE, J. Varejo no Brasil: gestão e estratégia. 1. ed. São Paulo: Atlas, 2011.

PROCON. Pesquisa comparativa de preços de medicamentos genéricos, 2013.

RANDALL, G. Trade Marketing Strategies: the partnership between manufacturers, brands and retailers. 2. ed. Oxford: Butterworth-Heinemann, 1994.

RIBEIRO, B. B.; ZILBER, M. A.; PRIETO, V. C. Formação de Alianças Estratégicas: estudo exploratório na área de varejo farmacêutico. Revista Eletrônica de Gestão de Negócios, v. 5, n. 4, p. 75-97, 2009.

ROSENBERG, L. J.; STERN, L. W. Toward the Analysis of Conflict in Distribution Channels: A Descriptive Model. Journal of Marketing, v. 34, n. 4, p. 40, out. 1970.

ROSENBLOOM, B. Conflict and channel efficiency: some conceptual models for the decision maker. The Journal of Marketing, v. 37, n. 3, p. 26-30, 1973.

ROSENBLOOM, B. Canais de Marketing: uma visão gerencial. 1. ed. São Paulo: Atlas, 2008 .

ROSLOW, S.; LASKEY, H. A.; NICHOLLS, J. A. F. The Enigma of Cooperative Advertising. Journal of Business \& Industrial Marketing, v. 8, n. 2, p. 70-79, 1993.

SANDOZ. Sitio da Organização no Brasil. Disponível em: $<$ http://www.sandoz.com.br/index.shtml. >. Acesso em: 23 maio. 2015a. 
SANDOZ. Sítio Global da Organização. Disponível em: <http://www.sandoz.com>. Acesso em: 23 maio. 2015 b.

SANDOZ. Sítio da Universidade Sandoz. Disponível em: $<$ http://www.unisandoz.com.br/login/index.php>. Acesso em: 21 maio. 2015c.

SCARE, R. F. A influência da estrutura organizacional na execução das atividades de marketing. 2008. 261f. Tese. (Doutorado em Administração) Universidade de São Paulo USP, 2008.

SERRALVO, F. A.; JOÃO, B. N.; CARDOSO, O. O. The importance of trade marketing on management relations in the consumer goods industry. International Journal of Business Research, v. 11, n. 6, p. 148-153, 2011.

SHANKAR, V. et al. Innovations in Shopper Marketing: Current Insights and Future Research Issues. Journal of Retailing, v. 87, p. S29-S42, jul. 2011.

SHIRAISHI, G. DE F. Estratégias da empresa e as estruturas de marketing. 2009. $280 \mathrm{f}$ Tese. (doutorado em administração) Universidade de São Paulo - USP, 2009.

SINDUSFARMA. Mercado Farmacêutico. Disponível em: $<$ http://sindusfarma.org.br/cadastro/index.php/site/ap_indicadores>. Acesso em: 7 jun. 2015.

TEIXEIRA, H. J.; SALOMÃO, S. M.; TEIXEIRA, C. J. Fundamentos da administração: a busca do essencial. 1. ed. Rio de Janeiro: Elsevier, 2010.

TOSETTO, A. Alan Tosetto: depoimento [28 de abril de 2015]. Entrevistador: Tatiana Ferrara Barros. São Paulo: Zambon, 2015. Arquivo sonoro em formato eletrônico. Entrevista realizada na seda da Zambon.

TOZZI, E. Vamos acabar com os chefes! E fazer home office! Exame.com, abr. 2014.

UNDERHILL, P. Vamos às compras!: a ciência do consumo nos mercados globais. Rio de Janeiro: Elsevier, 2009.

VASCONCELLOS, E.; HEMSLEY, J. R. Estruturas das Organizações: estruturas tradicionais, estruturas para inovação, estrutura matricial. 4. ed. São Paulo: Pioneira Thomson Learning, 2002.

VIEIRA, F.; ZUCCHI, P. Diferenças de preços entre medicamentos genéricos e de referência no Brasil. Rev Saúde Pública, v. 40, n. 3, p. 444-449, 2006.

VORMITTAG, F. F. Análise de opiniões de consumidores de medicamentos de venda livre. 2000. Tese. (Doutorado em Administração) Universidade de São Paulo - USP, 2000.

YAMAGUTI, C. L. et al. Gestão de marcas no contexto brasileiro. 1. ed. São Paulo: Saraiva, 2008.

YIN, R. K. Estudo de caso:planejamento e métods. 5. ed. Porto Alegre: Bookman, 2015. 
ZAMBON. Zambon Sítio Eletrônico. Disponível em: <http://www.zambon.com.br/br/zbrhome/zc-home/entry/0/936/0/home-page.html >. Acesso em: 23 maio. 2015a.

ZAMBON. Zambon Página Eletrônica Global. Disponível em: < http://www.zambongroup.com/it/zc-home/zc-home/entry/0/190/1/default.html >. Acesso em: 23 maio. 2015 b.

ZAMBON. Zambon Sitio Global da Divisão Farma. Disponível em: $<$ http://www.zambonpharma.com/it/zspa-homespa/zc-home/entry/0/241/0/default.html>. Acesso em: 23 maio. 2015c.

ZEYL, A.; ZEYL, A. Le trade marketing: ou la nouvelle logique des échanges producteurs-distributeurs. 1. ed. Paris: Vuibert, 1997. 


\title{
APÊNDICE
}

\section{APÊNDICE A - CARTA CONVITE}

\section{FEAUSP}

\author{
CARTA CONVITE DE PESQUISA DE CAMPO \\ UNIVERSIDADE DE SÃO PAULO - USP
}

FACULDADE DE ECONOMIA, ADMINISTRAÇÃO E CONTABILIDADE - FEA

São Paulo,__ de ___ de 2015.

$\grave{A}$

Prezado Senhor(a),

$\mathrm{O}(\mathrm{a})$ Sr.(a) está sendo convidado(a) para participar da pesquisa intitulada "As atividades de Trade Marketing aplicadas ao setor farmacêutico”, coordenada pelo Prof. Dr. Marcos Cortez Campomar, docente do Departamento de Administração de Empresas da Faculdade de Economia e Administração da Universidade de São Paulo (FEA-USP), conduzido pela aluna regular do curso de Mestrado em Administração da FEA-USP, Tatiana Ferrara Barros. Os resultados servirão como base para a elaboração de uma Dissertação Acadêmica.

O objetivo desta pesquisa é verificar quais são as funções e atividades desempenhadas pelo departamento de Trade Marketing na indústria farmacêutica. Este estudo será realizado por meio da aplicação de uma entrevista com gestores do departamento de Trade Marketing de Indústrias Farmacêuticas. O tempo estimado para respondê-la é de 60 minutos, organizados de modo a não interferir nas rotinas de trabalho. $\mathrm{O}$ (a) $\operatorname{sr}(\mathrm{a})$ não precisa responder às perguntas em que não se sentir a vontade em responder. $\mathrm{O}(\mathrm{a}) \operatorname{sr}(\mathrm{a})$ poderá interromper sua participação nessa pesquisa a qualquer momento que desejar, sem necessidade de justificativa. Não será necessário fornecer informações confidenciais da empresa.

A participação da é muito relevante para a conclusão deste estudo. De acordo com a vontade da organização, o nome da empresa poderá ou não ser divulgado na pesquisa, à medida que, a omissão do nome não prejudica o resultado da análise feita. Para participar da pesquisa será agendada uma visita presencial no local e horário de sua preferência para a aplicação da entrevista. 
Esclarecemos que sua participação na pesquisa é voluntária, e não haverá nenhum valor econômico, a receber ou a pagar, por sua colaboração. Entretanto o(a) sr(a) estará contribuindo para aumentar o conhecimento científico sobre o Trade Marketing. Além disso, após a finalização da dissertação, uma cópia do texto final será entregue a sua organização. Também poderá ser feita uma palestra gratuita customizada com a análise dos pontos encontrados em conjunção com a teoria estudada.

Todas as informações sobre os resultados desta pesquisa serão garantidas aos participantes a qualquer momento. Além disso, a divulgação dos resultados será feita em publicações científicas e/ou outros veículos (revistas, boletins). Caso o(a) $\operatorname{sr}(a)$ tenha alguma dúvida em relação à pesquisa, poderá entrar em contato com o coordenador da pesquisa, Prof. Marcos Cortez Campomar na Faculdade de Economia e Administração - FEA/USP, Av. Prof. Luciano Gualberto, 908 - Cidade Universitária Armando de Salles Oliveira, Butantã, São Paulo - SP, ou com a aluna de Mestrado Tatiana Ferrara Barros pelo endereço eletrônico tatiferrara@usp.br.

Agradecemos desde já pela colaboração, Saudações acadêmicas,

\section{Prof. Dr. Marcos Cortez Campomar}

Professor Titular de Marketing

Faculdade de Economia, Administração e Contabilidade

Universidade de São Paulo 


\section{APÊNDICE B - PROTOCOLO DE PESQUISA}

A) Visão geral do estudo de caso

1. Título: AS ATIVIDADES DE TRADE MARKETING APLICADAS AO SETOR FARMACÊUTICO

2. Dados dos pesquisadores:

Prof. Dr. Marcos Cortez Campomar

Telefone: (11) 3818-5842

Endereço: Av. Professor Luciano Gualberto, 908

Curriculum Lattes: http://lattes.cnpq.br/6639572131469325

Tatiana Ferrara Barros

RG: 43.623.221-2

CPF: $331.839 .338-02$

Telefone: (11) 99325-7470

Endereço: Av. Professor Luciano Gualberto, 908

Curriculum Lattes: http://lattes.cnpq.br/8722265895079338

3. Descrição do objetivo: verificar como ocorre o processo de desenvolvimento das atividades de Trade Marketing na indústria farmacêutica.

B) Procedimento de coleta de dados

1. Procedimento de campo:

Entrar em contato com Gerentes de Trade Marketing que atuam na Indústria Farmacêutica.

Encaminhar a carta convite para participação na pesquisa.

Após o aceite, combinar data com cada participante, em data, local e horário de mais conveniência.

2. Nome dos contatos para fazer o trabalho de campo
a. Biolab - Ana Paula
b. EMS - Diego
c. ZAMBON - Alan
d. Sandoz - Flávia

3. Preparação esperada anterior a coleta de entrevistas

a. Dados da empresa 
Empresa:

Endereço:

Endereço eletrônico:

Tipo de Capital:

Volume de Faturamento:

Linhas de Produtos da empresa:

4. Fontes de dados:

a. Entrevistas em profundidade com gerentes de Trade Marketing

b. Documentos internos e externos sobre a empresa

C) Questões para entrevistas.

O roteiro de entrevistas utilizado consta no APÊNDICE C 


\section{APÊNDICE C - ROTEIRO DE ENTREVISTAS}

\section{Dados do Entrevistado}

Nome:

Cargo atual:

Tempo no Cargo:

Tempo de atuação em Trade Marketing:

Setor ou área de atuação anterior:

A) Organização do Trade Marketing
a. Existe um departamento específico
b. Quantos departamentos de Trade Marketing existem na empresa
c. Há quanto tempo existe o departamento
d. A quem Trade Marketing responde
e. Está subordinado a qual gerência ou diretoria
f. Quais canais são atendidos pelo Trade Marketing
g. Como os canais são segmentados
h. Quantidade de pessoas
i. Quais os cargos
j. Promotores de vendas respondem para o setor. São terceirizados.
k. O que é Trade Marketing

B) Funções do Trade Marketing

a. Produto

i. Trade Marketing influência o mix de produtos dos clientes

ii. Trade Marketing leva informações sobre necessidades dos clientes em relação a novos produtos

iii. Trade Marketing influencia o desenvolvimento de embalagens de produtos, para adequá-los ao PDV e preocupando-se com a exposição

iv. Trade Marketing/promotor de vendas pode efetuar troca de produtos no ponto de venda em decorrência de estar rasgada ou feia

v. Característica ou desafio peculiar do setor farmacêutico quanto ao produto

b. Preço

i. Participa do processo de definição do preço do produto para diferentes clientes

ii. O Trade Marketing participa em alguma etapa da formação de preços

iii. Característica ou desafio peculiar do setor farmacêutico quanto ao preço

c. Relacionamento com o cliente

i. Treinamentos da equipe de vendas do cliente

ii. Portal online ou aplicativo especifico para a equipe dos clientes

iii. Participação no processo de remuneração do cliente

iv. Suporte para melhorias na operação do canal

v. Programas de incentivo para a equipe do canal

vi. Compartilhamento de informações

vii. Utilização de indicadores de desempenho em conjunto

viii. Promotores exclusivos para os principais clientes 
ix. Lançamento de produto dedicado aos principais clientes

d. Sistema de Informação de Trade Marketing

i. Traz informações do ponto de venda para marketing ou vendas

ii. Ações da concorrência

iii. Fiscaliza ações negociadas

iv. Informações sobre a comunicação e produtos

v. Equipe de promotores são treinados para trazer informações

vi. Há relatórios com informações sobre as visitas

e. Feiras e eventos do setor

i. O departamento é responsável por organizar a participação em feiras

ii. Quais tipos de feiras

f. Comportamento do shopper

i. O departamento é responsável por efetuar pesquisas sobre comportamento do shopper

ii. Efetuam a análise da informação de pesquisas

iii. O que fazem com estas informações

g. Gerenciamento por categorias

i. Auxiliam os varejistas a categorizar seus produtos

ii. Sinalizam o capitão da categoria

h. Comunicação no PDV

i. Desenvolvem materiais (displays, folders)

ii. Recebe demanda dos clientes por materiais

iii. Quais ações de promoção de vendas efetuam (brindes, amostras, experimentação e demonstração

iv. Enviam promotores para efetuar ações de merchandising

v. Outras ações não citadas

vi. As ações são diferentes de acordo com o porte do cliente

vii. O Trade Marketing é responsável pela negociação de gôndolas

viii. É responsável pela inserção no tabloide

ix. Característica peculiar do setor, interferência da legislação quanto as ações

i. Plano de Trade Marketing

i. Tem um plano de Trade Marketing

ii. Plano anual de promoções por cliente

iii. Efetuam planos em colaboração com o cliente

j. Métricas de Trade Marketing

i. Mensuram o retorno das ações efetuadas

ii. Que indicadores usam

iii. Existem outros retornos além do financeiro

iv. Acredita que as ações são benéficas para os clientes

C) Especificidades do setor

a. Como a força do varejista interfere nas ações de Trade 
b. Alterações no mercado farmacêutico que interferem nas ações de Trade Marketing

c. A Anvisa e demais legislações interferem nas ações de Trade Marketing

d. Tipo de produto influencia a ações de Trade Marketing

e. Processo de decisão de compra

D) Considerações Finais

a. Comentário final sobre algo que não foi abordado

E) Autorizações

a. nome da empresa no trabalho

b. nome do participante no trabalho 